US Army Corps

of Engineers ${ }_{\circledast}$

Engineer Research and

Development Center

Monitoring Completed Navigation Projects Program

\title{
Periodic Inspections of Cleveland Harbor East Breakwater, Ohio, and Burns Harbor North Breakwater, Indiana
}

Glenn B. Myrick, Jeffrey A. Melby, and Elizabeth C. Burg

May 2015

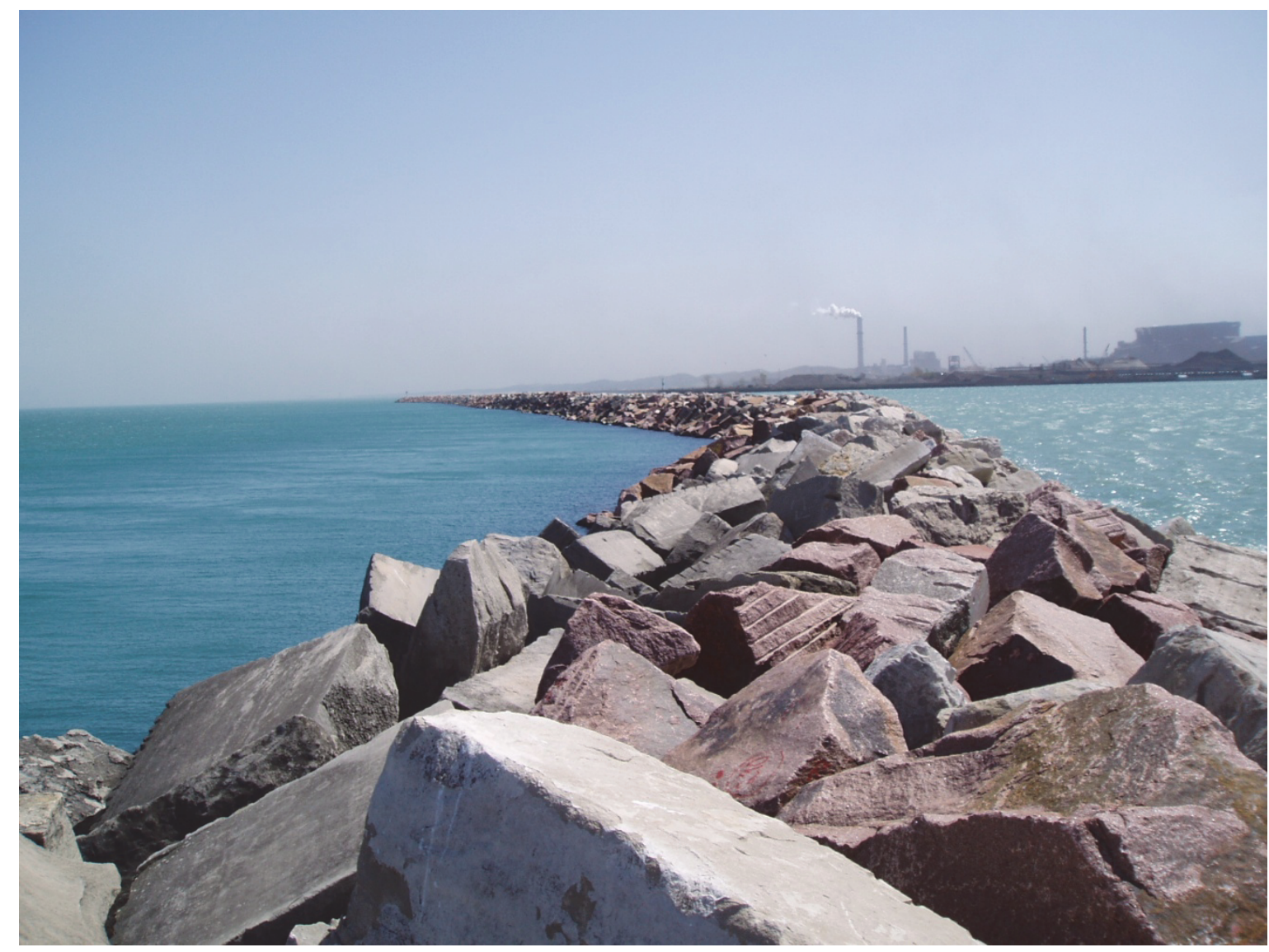


The U.S. Army Engineer Research and Development Center (ERDC) solves the nation's toughest engineering and environmental challenges. ERDC develops innovative solutions in civil and military engineering, geospatial sciences, water resources, and environmental sciences for the Army, the Department of Defense, civilian agencies, and our nation's public good. Find out more at www.erdc.usace.army.mil.

To search for other technical reports published by ERDC, visit the ERDC online library at http://acwc.sdp.sirsi.net/client/default. 


\section{Periodic Inspections of Cleveland Harbor East Breakwater, Ohio, and Burns Harbor North Breakwater, Indiana}

Glenn B. Myrick, Jeffrey A. Melby, and Elizabeth C. Burg

Coastal and Hydraulics Laboratory

U.S. Army Engineer Research and Development Center

3909 Halls Ferry Road

Vicksburg, MS 39180-6199

Final report

Approved for public release; distribution is unlimited.

Prepared for U.S. Army Corps of Engineers

441 G. Street, NW

Washington, DC 20314-1000

Under MCNP Work Unit A1050 


\section{Abstract}

Monitoring Completed Navigation Projects (MCNP) Program evaluates the structural and functional performance of existing navigation structures. Under Periodic Inspections, aerial photography, ground-truth surveys, walking inspections, photogrammetry, and lidar elevation data are used to periodically assess the structural conditions of selected structures. A database of these structures is being compiled for asset management and other purposes.

Cleveland Harbor East Breakwater, $\mathrm{OH}$, has sustained extensive damage since its construction in 1915. The Breakwater has had an extensive repair history, including a major rehabilitation in 1979- 80 involving the placement of 2-ton dolosse on the lakeward slope and crest of the easterly 4,400 feet ( $\mathrm{ft}$ ). Some failed and were replaced with 4-ton dolosse. Other repairs took place in 1986, 1989, 1991, and 2001 on the nondolos sections.

Burns Harbor North Breakwater, IN, is a 4,640 ft rubble-mound structure constructed in 1969. The Breakwater has required extensive maintenance including the addition of 290 kilotons of stone through 1989. A submerged reef was constructed between 1995 and 1998, $75 \mathrm{ft}$ lakeward of the Breakwater, to reduce wave energy reaching the structure.

Records indicate that 1,128 broken and/ or cracked dolosse, and 282 damaged armor stones, were documented during the 2006 Periodic Inspections of Cleveland Harbor East Breakwater and Burns Harbor North Breakwater, respectively. This interim data report contains a precise record of dolos and stone armor damage existing in J uly 2006 on these structures. A comprehensive analysis and technical report correlating this damage with storm and water level conditions will be published at a later date as subsequent additional field data are obtained at these two Great Lakes breakwaters.

DISCLAIMER: The contents of this report are not to be used for advertising, publication, or promotional purposes. Citation of trade names does not constitute an official endorsement or approval of the use of such commercial products. All product names and trademarks cited are the property of their respective owners. The findings of this report are not to be construed as an official Department of the Army position unless so designated by other authorized documents. 


\section{Contents}
Abstract
ii

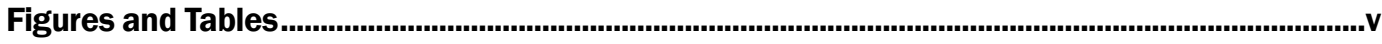

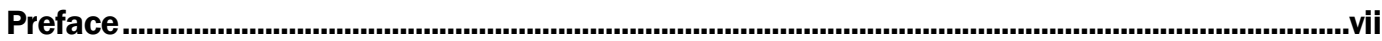

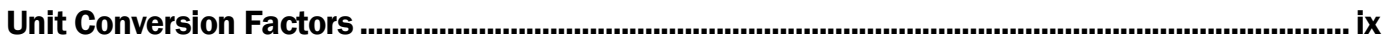

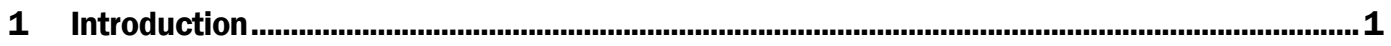
1.1 Monitoring Completed Navigation Projects (MCNP) program ................................. 1
1.2 Work unit objective and monitoring approach ..................................................... 2
1.3 Project locations and brief histories .............................................................. 3

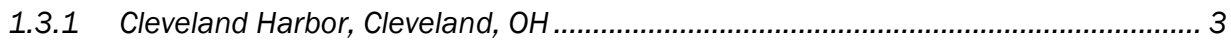
1.3.2 Burns Harbor, Portage, IN ............................................................................... 8
1.4 Dolos armor units and break types .......................................................... 12

2 Cleveland Harbor East Breakwater Prior Monitoring .............................................................16

2.1 Cleveland Harbor East Breakwater 1980-1985 initial monitoring......................... 16

2.1.1 Dolos armor monitoring ................................................................................ 16

2.1.2 Stone armor monitoring................................................................................. 19

2.2 Cleveland Harbor East Breakwater 1993 Periodic Inspections monitoring.............20

2.3 Cleveland Harbor East Breakwater 1997 Periodic Inspections walking

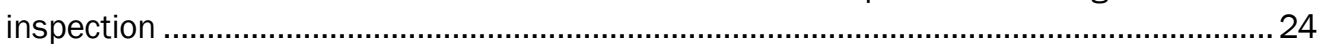

2.4 Cleveland Harbor East Breakwater 2004 Periodic Inspections walking

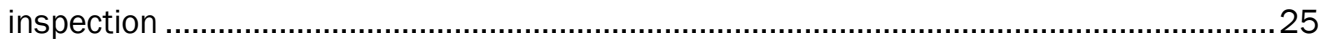

3 Burns Harbor North Breakwater Prior Monitoring ...................................................................27

3.1 Burns Harbor North Breakwater 1985-1992 initial monitoring (comprehensive)

3.2 Burns Harbor North Breakwater 1994-1995 Periodic Inspections monitoring (base conditions) 30

3.3 Burns Harbor North Breakwater 1999 Periodic Inspections walking inspection

3.4 Burns Harbor North Breakwater 2004 Periodic Inspections walking inspection

42006 Periodic Inspections Monitoring Plan and Walking Inspections ................................35

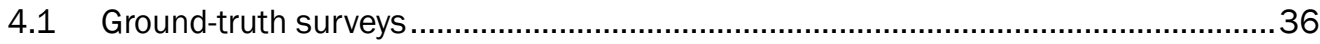

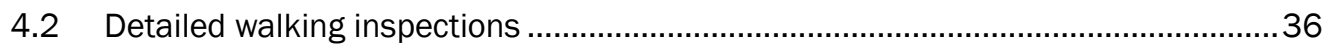

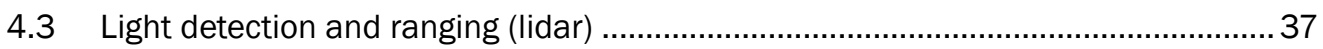

4.42006 Periodic Inspections walking inspections ....................................................38

4.4.1 Cleveland Harbor East Breakwater broken dolos walking inspection ..................... 38

4.4.2 Burns Harbor North Breakwater broken stone walking inspection.......................... 42 
5 Summary and Conclusions .................................................................................................45

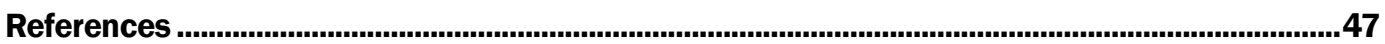

Appendix A: Broken/Damaged Dolos Armor Units (Type of Breaks and Locations) on the Cleveland Harbor East Breakwater, July 2006 Walking Inspection ...................................50

Appendix B: Broken/Damaged Stone Armor Units (Type of Stone and Breaks) on Burns Harbor North Breakwater, August 2006 Walking Inspection .

Report Documentation Page 


\section{Figures and Tables}

\section{Figures}

Figure 1. Location of Cleveland Harbor, Cleveland, $\mathrm{OH}$.

Figure 2. Cross section of western 3,000 ft section of Cleveland Harbor East Breakwater as originally constructed.

Figure 3. Cross section of eastern 17,970 ft section of Cleveland Harbor East Breakwater as originally constructed.

Figure 4. Cleveland Harbor, Cleveland, $\mathrm{OH}$, south shore of Lake Erie, looking east............................ 6

Figure 5. Cross section of major dolosse rehabilitation area of eastern 4,400 ft section of Cleveland Harbor East Breakwater following 1980 rehabilitation.

Figure 6. Aerial photograph of Cleveland Harbor East Breakwater head. Note the 4-ton dolosse used in 1987 repairs.

Figure 7. Cleveland Harbor East Breakwater layout with stone (1985-1992) and dolos (1986) rehabilitation areas.

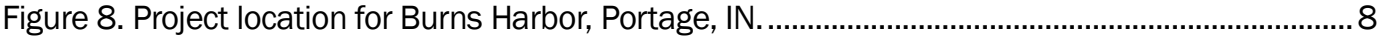

Figure 9. Cross section of original Burns Harbor North Breakwater. ..................................................

Figure 10. Layout of Burns Harbor, Portage, IN. ………….......................................................10

Figure 11. Layout of submerged reef breakwaters lakeward of existing North Breakwater,

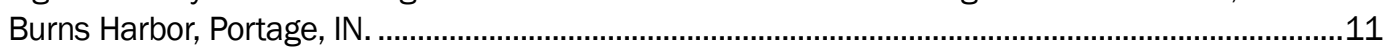

Figure 12. Burns Harbor, Portage, IN, south shore of Lake Michigan, looking north........................12

Figure 13. Various views of a dolos armor unit.................................................................................

Figure 14. Example of a dolos angled midshank break. ..................................................................14

Figure 15. Example of a dolos angled fluke-shank break. ..............................................................14

Figure 16. Example of a dolos straight fluke-shank break...............................................................15

Figure 17. Example of a dolos broken fluke tip. ...............................................................................15

Figure 18. Cumulative number of broken dolos armor units located during 1980-1985 initial monitoring (comprehensive), Cleveland Harbor East Breakwater (after Pope et al. 1993)

Figure 19. Example of a survey monument on Cleveland Harbor East Breakwater..........................21

Figure 20. Distribution of broken dolos armor units along Cleveland Harbor East Breakwater relative to station number, June 1993 monitoring (after Bottin et al. 1995).

Figure 21. Example of void on lake side of Cleveland Harbor East Breakwater between sta. $230+40$ and sta. $230+70,2004$ walking inspection.

Figure 22. Control points for Burns Harbor North Breakwater August 1999 walking inspection.

Figure 23. Distribution of broken armor stones on Burns Harbor North Breakwater, August 1999 walking inspection (after Bottin and Tibbetts 2000)

Figure 24. Burns Harbor North Breakwater, August 1999 walking inspection, looking east.

Figure 25. Burns Harbor North Breakwater, April 2004 walking inspection after repairs, looking east. 
Figure 26. Lidar data from Burns Harbor North Breakwater, Portage, IN. ........................................38

Figure 27. Water level (m) time history from NOAA offshore gauge 9063063, Cleveland Harbor East Breakwater, July 2006 detailed walking inspection.

Figure 28. Distribution of damaged dolos armor units along Cleveland Harbor East Breakwater relative to station number, July 2006 detailed walking inspection..................................39

Figure 29. Example of station number layout for Cleveland Harbor East Breakwater. 40

Figure 30. Cumulative number of broken dolos armor units, including July 2006 detailed walking inspection, Cleveland Harbor East Breakwater.

Figure 31. Water level (m) time-history from NOAA offshore gauge 9087044, Burns

Harbor North Breakwater, August 2006 detailed walking inspection. 42

Figure 32. Distribution of damaged stone armor units along Burns Harbor North Breakwater relative to station number, August 2006 detailed walking inspection.

Figure 33. Locations of broken armor stones along Burns Harbor North Breakwater, August 2006 detailed walking inspection.

Figure 34. Burns Harbor North Breakwater looking east, August 2006 detailed walking inspection.

\section{Tables}

Table 1. Monument positions for 1993 survey of Cleveland Harbor East Breakwater. .22 


\section{Preface}

This interim data report describes procedures and results of a periodic inspection during J uly 2006 of dolos concrete armor units on the Cleveland Harbor East Breakwater, Cleveland, $\mathrm{OH}$, and of stone armor units on the Burns Harbor North Breakwater, Portage, IN. This report contains a precise record of dolos and stone armor damage existing in J uly 2006. A comprehensive analysis and technical report correlating this damage with storm and water level conditions will be published at a later date as subsequent additional field data are obtained at these two Great Lakes breakwaters. The study was performed by the U.S. Army Engineer Research and Development Center (ERDC), Coastal and Hydraulics Laboratory (CHL), for Headquarters, U.S. Army Corps of Engineers (HQUSACE).

The study reported herein was conducted under the Periodic Inspections work unit of the Monitoring Completed Navigation Projects (MCNP) program. MCNP is one of the USACE Navigation Programs. HQUSACE administers the overall program, and CHL manages the program. Principal investigator for the Periodic Inspections work unit at the time of this study was Dr. J effrey A. Melby, CHL. The Program Manager for the MCNP Program is Dr. Lyndell Z. Hales, CHL. Points-of-contact at the U.S. Army Corps of Engineers (USACE) Buffalo District (CELRB) for Cleveland Harbor are Shanon A. Chader and Michael C. Mohr. Tim Kroll is the point-ofcontact for the USACE Chicago District (CELRC) for Burns Harbor.

CELRB provided ground surveys for both harbor breakwaters. Aerial photography and lidar elevation data were provided by the J oint Airborne Lidar Bathymetry Technical Center of Expertise (JALBTCX), Stennis Space Center, MS.

In J uly 2006, Chader and Mohr and Glenn B. Myrick and Elizabeth C. Burg, CHL, conducted a walking inspection of the Cleveland Harbor East Breakwater. Dennis Rimmer, CELRB, provided boating support for the Cleveland inspection. In August 2006, Andrew R. Benziger, Mike Fornak, and Andrew Montez, CELRC, along with Myrick and Burg, conducted a walking inspection of Burns Harbor North Breakwater. Melvin McLaurin, CELRC, provided boat support for the Burns Harbor North Breakwater inspection. 
This study was performed under the general supervision of Thomas W. Richardson, former Director, CHL. Direct supervision of this project was provided by J osé E. Sánchez, former Chief, Harbors, Entrances, and Structures Branch (HESB), CHL.

During preparation and publication of this report, J osé E. Sánchez was Director, CHL; Dr. J acqueline S. Pettway was Chief, Navigation Division (ND), CHL; Dr. Donald L. Ward was former Acting Chief, HESB, ND; and J ames D. Gutshall, was Chief, HESB, ND. Program Monitor for the MCNP program was J effrey A. McKee, Chief, Navigation Branch, HQUSACE.

At the time of publication of this report, LTCJ ohn T. Tucker III was Acting Commander of ERDC. Dr. J effery Holland was Director. 


\section{Unit Conversion Factors}

\begin{tabular}{|l|c|l|}
\hline Multiply & By & To Obtain \\
\hline degrees (angle) & 0.01745329 & radians \\
\hline feet & 0.3048 & meters \\
\hline inches & 2.54 & centimeters \\
\hline miles (U.S. statute) & 1.609347 & kilometers \\
\hline pounds (mass) & 0.45359237 & kilograms \\
\hline tons (2,000 pounds, mass) & 907.1847 & kilograms \\
\hline tons (2,000 pounds, mass) & 0.9071847 & megagrams \\
\hline
\end{tabular}




\section{Introduction}

\subsection{Monitoring Completed Navigation Projects (MCNP) program}

The goal of the MCNP program (formerly Monitoring Completed Coastal Projects [MCCP] program) is the advancement of coastal and hydraulic engineering technology. The program is designed to determine how well projects are accomplishing their purpose and how well they are resisting attacks by their physical environment. These determinations, combined with concepts and understanding already available, can (a) lead to the creation of more accurate and economical engineering solutions to coastal and hydraulic problems, (b) strengthen and improve design criteria and methodology, (c) improve construction practices and cost-effectiveness, and (d) improve operations and maintenance techniques. Additionally, the MCNP program will identify where current technology is inadequate or where additional research is required.

USACE in 1978 established an ad hoc committee of engineers and scientists to develop direction for the MCNP program. The committee formulated the objectives of the program, developed its operational philosophy, recommended its funding level, and established criteria and procedures for project selection. A significant result of their efforts was a prioritized listing of problem areas to be addressed. This is essentially a listing of the areas of interest of the program.

USACE offices are invited to nominate projects for inclusion in the MCNP program as funds become available. The MCNP program is governed by Engineer Regulation (ER) 1110-2-8151 (USACE 1997). A selection committee reviews and prioritizes the nominated projects on criteria established in the ER. The prioritized list is reviewed by the Program Monitor at HQUSACE. Final selection is based on this prioritized list, national priorities, and available funding.

The MCNP program is managed by ERDC, CHL, with guidance from HQUSACE. An individual monitoring project is a cooperative effort between the submitting USACE District and/ or Division office and CHL. 


\subsection{Work unit objective and monitoring approach}

The Periodic Inspections work unit was initiated in 1993 to provide longterm structural performance monitoring. Sites for periodic inspection are selected from previous MCCP or MCNP projects or based on the site's unique design features. Normally, sites selected for inclusion in the Periodic Inspections work unit have an intensive baseline survey. The structures are then monitored periodically, based on prioritized needs and funding, and evaluated for structural changes. A database of periodic inspections information is available that includes data that have been collected over several years through the Periodic Inspections work unit.

This interim data report describes procedures and results of a periodic inspection during J uly 2006 of dolos concrete armor units on the Cleveland Harbor East Breakwater, Cleveland, $\mathrm{OH}$, and of stone armor units on the Burns Harbor North Breakwater, Portage, IN. This report contains a precise record of dolos and stone armor damage existing in J uly 2006. A comprehensive analysis and technical report correlating this damage with storm and water level conditions will be published at a later date as subsequent additional field data are obtained at these two Great Lakes breakwaters.

Traditional means of evaluations have included aerial photography and photogrammetry of above-water conditions of structures, in coordination with ground-truth surveys and detailed walking inspections. Due to funding constraints, photogrammetry was not performed for the Cleveland Harbor East Breakwater or the Burns Harbor North Breakwater during the 2006 inspections but was replaced with lidar technology. Lidar technology incorporates other advantages over photogrammetry (described in detail later in this report). Only the dolos concrete armor unit section of the Cleveland Harbor East Breakwater and the Burns Harbor North Breakwater, which is entirely armored with stone units, were included in this data acquisition,.

Recent extensive rehabilitation of the Burns Harbor North Breakwater in 2005 makes direct comparison of this 2006 Periodic Inspection to past monitoring impossible. This 2006 Periodic Inspection has provided data and documentation that can be used as a new baseline for future monitoring. 


\subsection{Project locations and brief histories}

\subsubsection{Cleveland Harbor, Cleveland, $\mathrm{OH}$}

Cleveland Harbor is located on the southern shore of Lake Erie, 96 miles east of Toledo, $\mathrm{OH}$, and 176 miles west of Buffalo, NY (Figure 1). The Harbor is the 47th leading U.S. port with 13.6 million tons of material shipped or received in 2005, also ranking it 5th among the Great Lakes ports. Major commodities shipped or received include iron ore, limestone, sand and gravel, cement and concrete, salt, general cargo, and liquid bulk (USACE 2006).

Figure 1. Location of Cleveland Harbor, Cleveland, $\mathrm{OH}$.

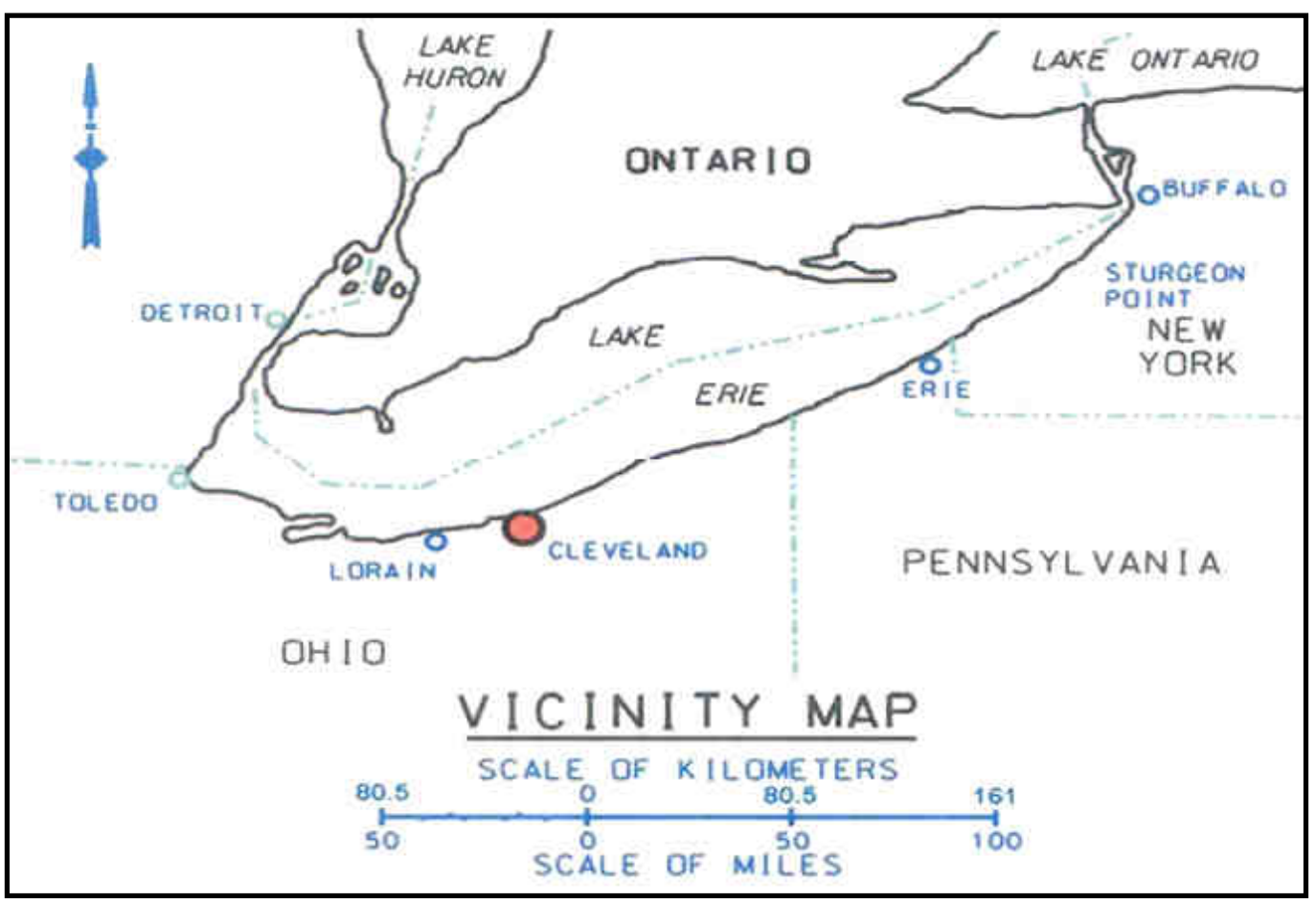

Construction of the harbor began in 1875 at the mouth of the Cuyahoga River with a stone-filled concrete pier. Early construction of the 6,084 feet (ft) West Breakwater consisted of stone-filled timber cribs and was completed in 1884. The design crest elevation of the West Breakwater was $+12 \mathrm{ft}$ low water datum (lwd) with a crest width of $32 \mathrm{ft}$. Since initial construction, a concrete cap, riprap, and a lakeside stone superstructure have been added to the West Breakwater. Early construction of the $20,970 \mathrm{ft}$ East Breakwater began in 1887 and was completed in 1915. The westerly $3000 \mathrm{ft}$ was constructed of stone-filled timber cribs with a concrete cap. A stone superstructure was added lakeside between 1917 and 1926 
(Figure 2). The remaining easterly 17,970 ft was constructed using dumped core stone with large, individually placed armor stone at a design elevation of $+10.3 \mathrm{ft} \mathrm{lwd}$ and a crest width of $10.0 \mathrm{ft}$ (Figure 3). More details of early construction can be found in Bottin (1988).

Figure 2. Cross section of western 3,000 ft section of Cleveland Harbor East Breakwater as originally constructed.

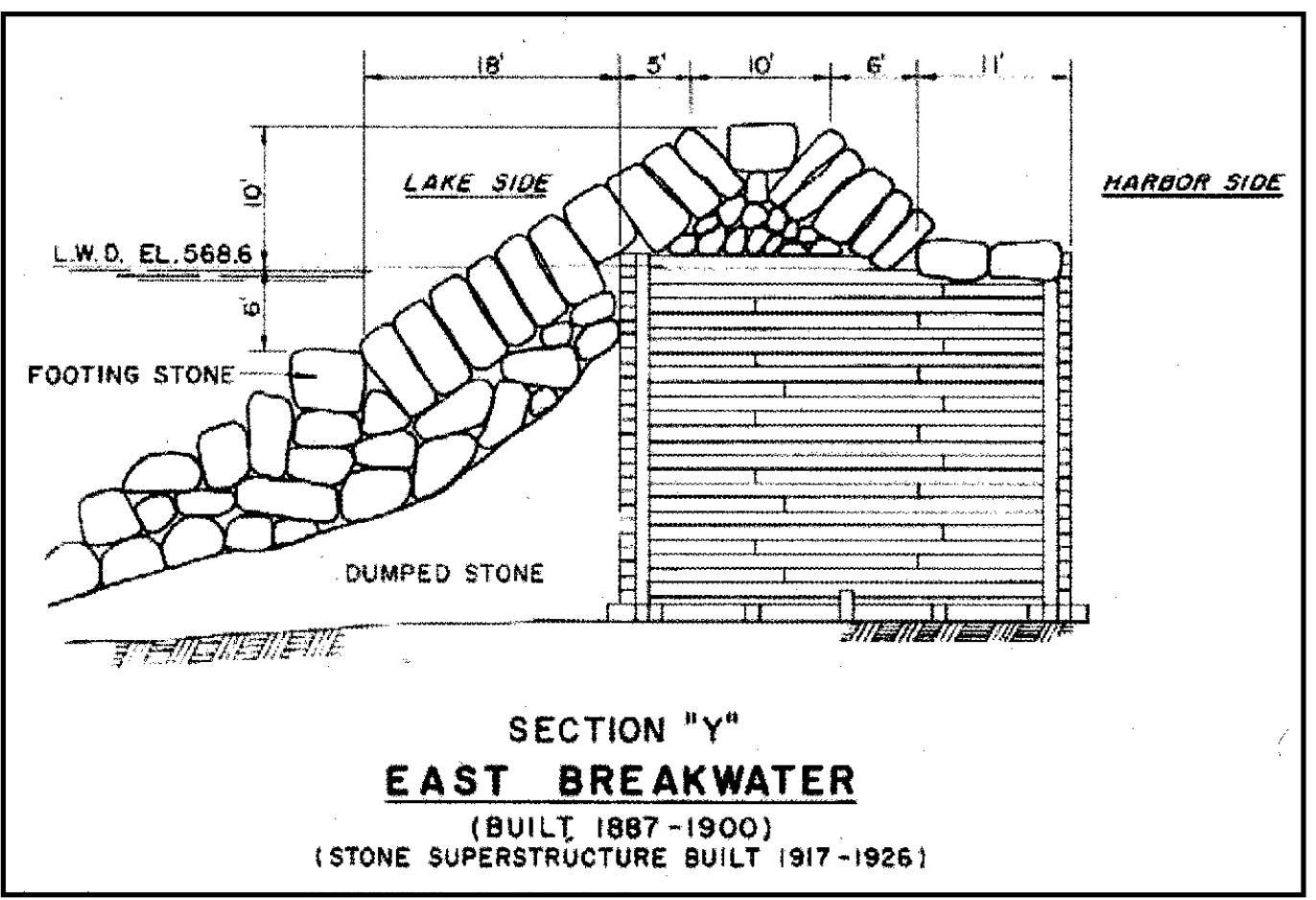

Figure 3. Cross section of eastern $17,970 \mathrm{ft}$ section of Cleveland Harbor East Breakwater as originally constructed.

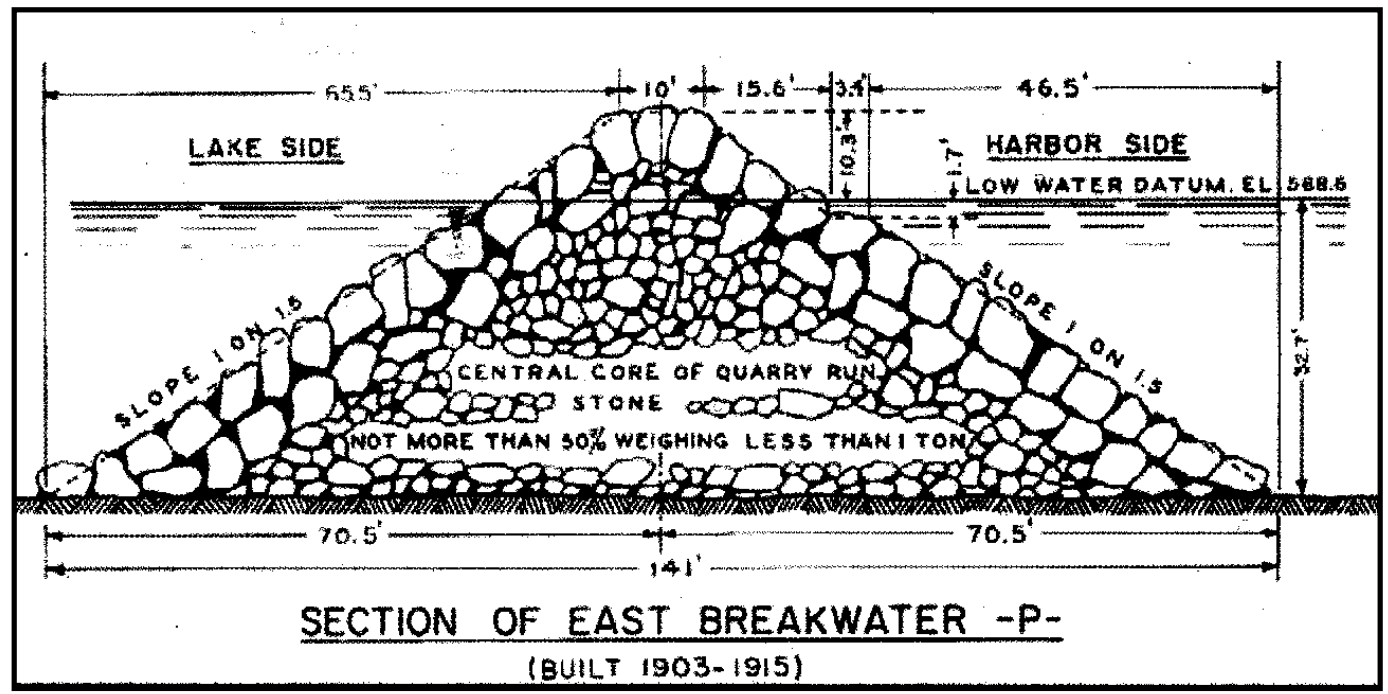


At that time, lwd on the Great Lakes (el $568.60 \mathrm{ft}$ ) was referenced to International Great Lakes Datum 1955 (IGLD55), which was mean water line (mwl) at Father Point, Rimouski, Quebec, Canada, at the mouth of the St. Lawrence Seaway. In 1985, lwd on the Great Lakes was redefined to el 569.20, and became IGLD85. The lwd on the Great Lakes also was the National Geodetic Vertical Datum of 1929 (NGVD29) at el $569.43 \mathrm{ft}$. Thus, NGVD29 was $0.23 \mathrm{ft}$ higher than IGLD85.

In 1971, the U.S. National Oceanic and Atmospheric Administration (NOAA), National Geodetic Survey (NGS), initiated a general adjustment of NGVD29. When completed in 1988, this adjustment became NAVD88. This minimum-constraint adjustment of Canadian-Mexican-U.S. leveling observations was performed holding fixed the height of the primary tidal benchmark referenced to IGLD85 local mean sea level height value at Father Point, Canada. This constraint satisfied the requirement of shifting the datum vertically to minimize impact of NAVD88 on U.S. Geological Survey mapping products and also provided the datum point desired by the IGLD Coordinating Committee. IGLD85 and NAVD88 are now one and the same, according to NGS (Zilkoski et al. 1992; Zilkoski 1993).

Presently, the East and West Breakwaters provide Cleveland Harbor with over 30,000 ft of navigation sheltering (Figure 4). There are two harbor entrances from Lake Erie. The westerly entrance is directly lakeward of the mouth of the Cuyahoga River. East and west rubble-mound arrowhead breakwaters were added to protect this entrance. They are each 1,250 ft long with a crest elevation of $+8 \mathrm{ft}$ lwd and a crest width of $10 \mathrm{ft}$. The easterly entrance is between the shoreline and the East Breakwater at the east end of the harbor. A U.S. Coast Guard lighthouse is mounted to a 21 by $21 \mathrm{ft}$ square concrete base on the center of the East Breakwater head.

The East Breakwater has had an extensive repair and rehabilitation history. Storm damage caused armor stone displacement and subsequent unraveling of the breakwater slope in many areas. Frequent repairs were made using original construction methods until a major rehabilitation in 1979- 1980. This construction involved the placement of 2-ton dolosse on the lakeward slope and damaged crest of the easterly 4,400 ft of the East Breakwater. Dolosse were placed at a 1V:2H slope on the breakwater trunk and a $1 \mathrm{~V}: 2.5 \mathrm{H}$ slope on the breakwater head to provide armoring (Figure 5). 
Figure 4. Cleveland Harbor, Cleveland, $\mathrm{OH}$, south shore of Lake Erie, looking east.

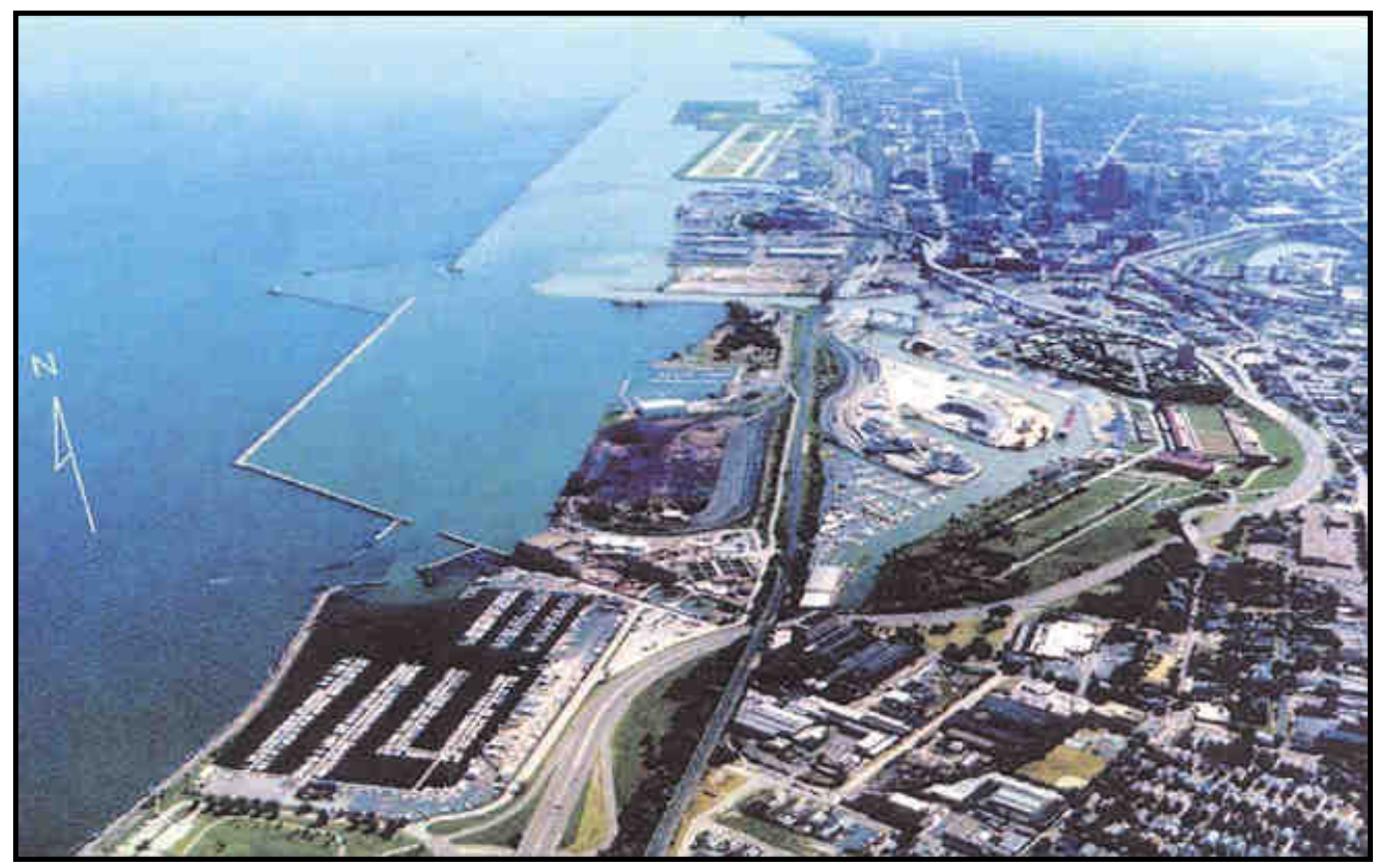

Figure 5. Cross section of major dolosse rehabilitation area of eastern $4,400 \mathrm{ft}$ section of Cleveland Harbor East Breakwater following 1980 rehabilitation.

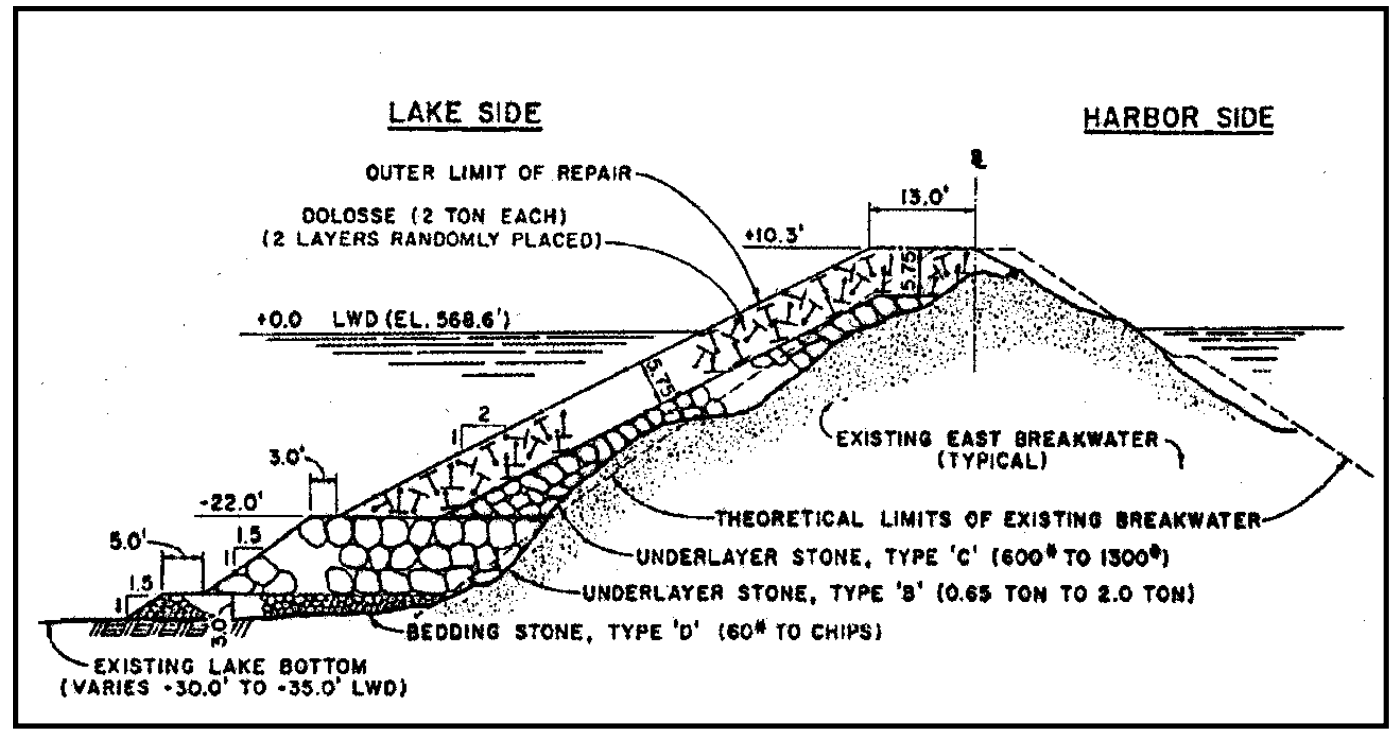

The winter of 1986- 1987 resulted in higher-than-normal lake levels and produced several storms. In the spring of 1987, it was discovered that most of the 2-ton dolosse were missing from the head of the East Breakwater. These were replaced with 4-ton dolosse, and some additional armor units were placed in depressed areas along the trunk. Earlier laboratory tests and breakwater inspections supported the concept that the 2-ton dolosse were under designed for conditions at Cleveland Harbor East Breakwater 
(Markle and Dubose 1985). An aerial photograph of the breakwater head (Figure 6) shows the size difference in the 2-ton and 4-ton dolosse. Other recent repairs to the East Breakwater took place in 1986, 1989, 1991, and 2001 on various sections of the westerly 16,570 ft. No dolosse were used in these areas. The harbor layout and repair/ rehabilitation areas can be seen in Figure 7.

Figure 6. Aerial photograph of Cleveland Harbor East Breakwater head. Note the 4-ton dolosse used in 1987 repairs.

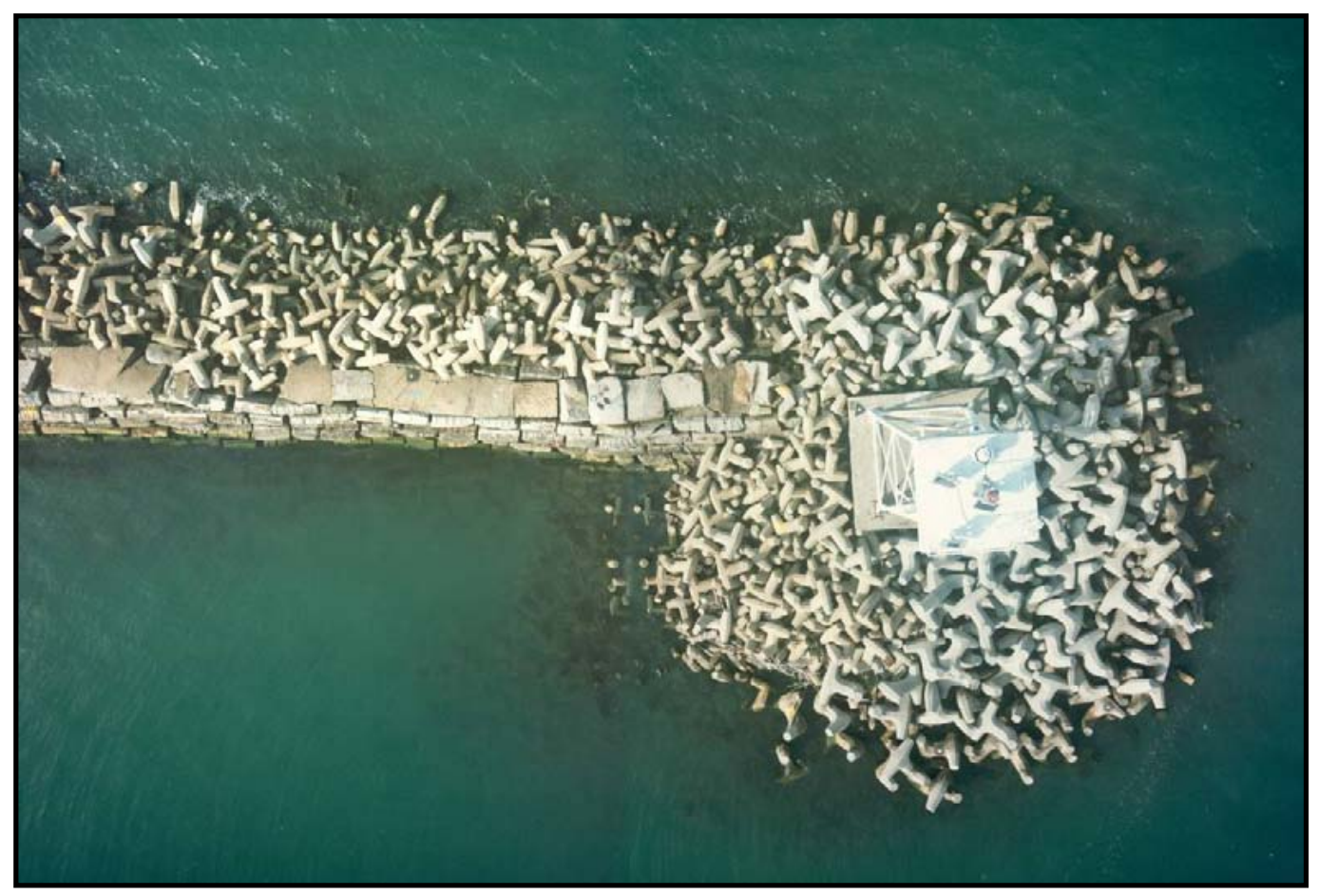

Figure 7. Cleveland Harbor East Breakwater layout with stone (1985-1992) and dolos (1986) rehabilitation areas.

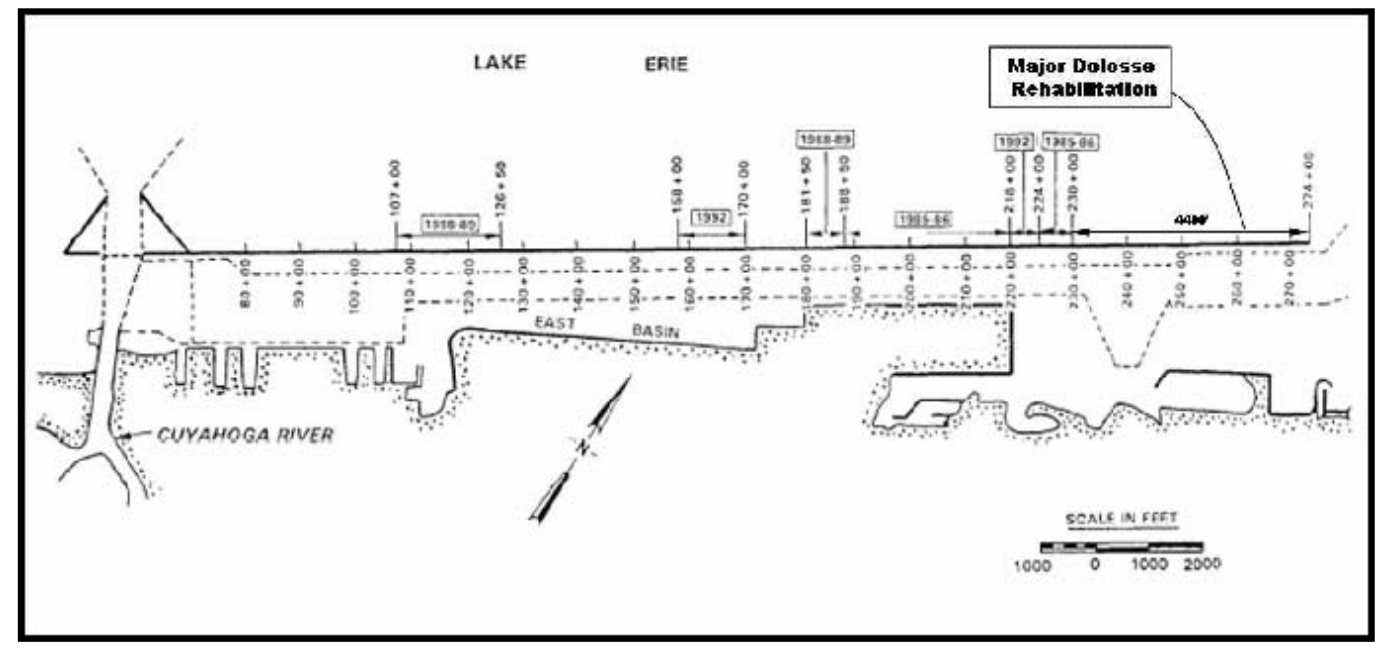




\subsubsection{Burns Harbor, Portage, IN}

Burns Harbor is located approximately 30 miles by land and 18 nautical miles southeast of Chicago, IL, on the southern shoreline of Lake Michigan (Figure 8). It is the 56th leading port in the United States. Latitude and longitude coordinates for the harbor are 41038'56" N, 87 008'45” W. An increase in industrial facilities in the area, namely steel corporations, and the opening of the St. Lawrence Seaway in 1959 increased the demand for navigational shipping and the need for a new deepwater port.

Figure 8. Project location for Burns Harbor, Portage, IN.

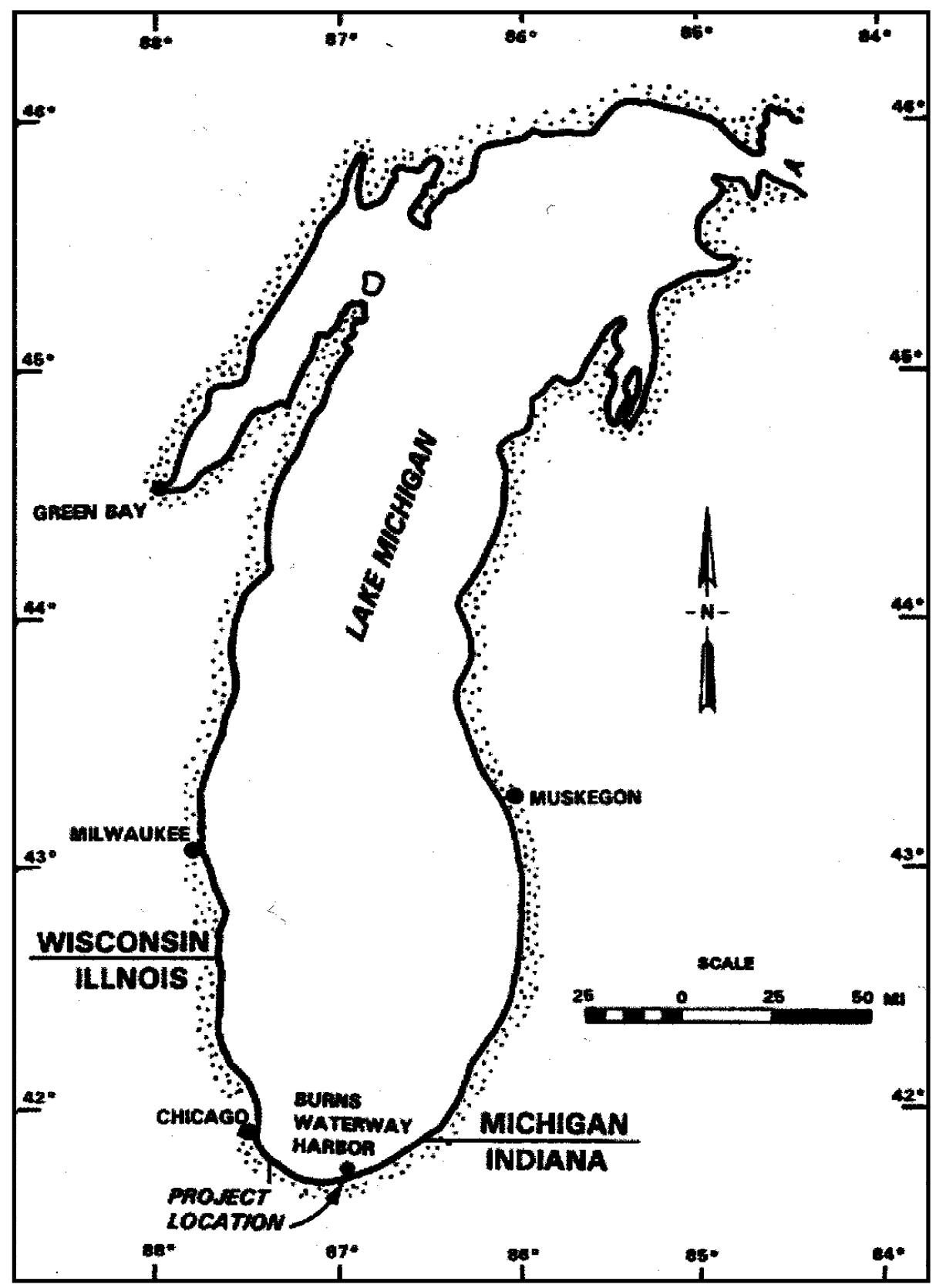


The state of Indiana created the Indiana Port Commission in 1960, and a USACE report recommended building a port at the present site (McGavock et al. 1969). Congress authorized the construction of the harbor by the River and Harbor Act of 27 October 1965. Design for the harbor layout was developed by the University of Florida (UF) (1964) for the Indiana Port Commission using a three-dimensional (3D) hydraulic physical model study to investigate wave and current phenomena associated with the proposed harbor (UF 1964). Detailed 1V:35H scaled two-dimensional (2D) physical model studies at ERDC (Waterways Experiment Station) were used to determine the final cross-section design for the breakwater in 1966 (J ackson 1967). This design was a multilayered rubble-mound structure with cut Indiana Bedford limestone armor. This armor was rectangular in shape, with each stone weighing between 10 to 15 tons on the trunk and 15 to 20 tons on the head. The armor was randomly placed in two layers which, at the time, was an unusual construction method. The design crest elevation was $+14 \mathrm{ft}$ lwd. The depth of the lakeside toe ranged from 31 to $41 \mathrm{ft}$. Side slopes on both lake and harbor sides were 1V:1.5H. Crosssection design for the original construction can be seen in Figure 9.

Figure 9. Cross section of original Burns Harbor North Breakwater.

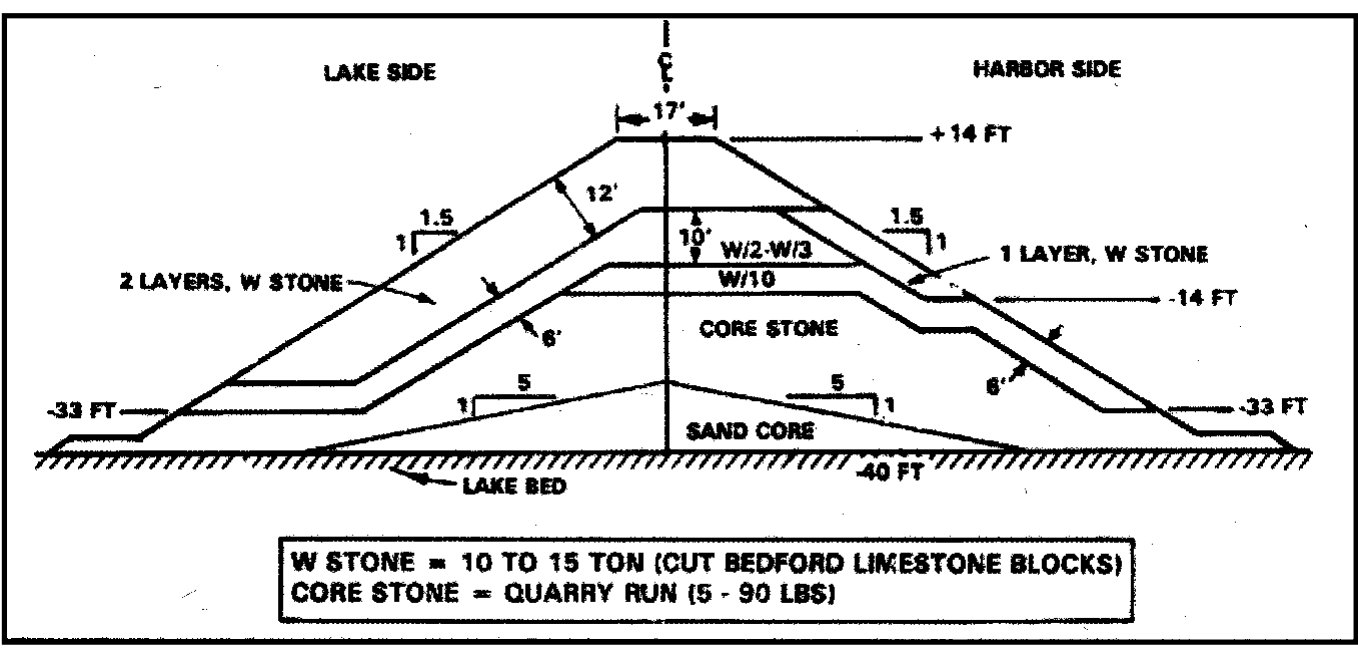

Burns Harbor has 5,840 ft of breakwater structures including a 4,640 ft rubble-mound North Breakwater with an east-west alignment and a connecting 1,200 ft rubble-mound West Breakwater Arm with a northsouth alignment toward the shoreline. A cellular sheet-pile extension connects the West Breakwater Arm to the shore. Lakeside toe depth ranges from - 30 to $-41 \mathrm{ft}$ lwd. The authorized channel depth is $-30 \mathrm{ft}$ lwd at the entrance and $-28 \mathrm{ft}$ lwd in the Harbor. Original construction of Burns Harbor was completed in 1969. The harbor layout is shown in Figure 10. 
Figure 10. Layout of Burns Harbor, Portage, IN.

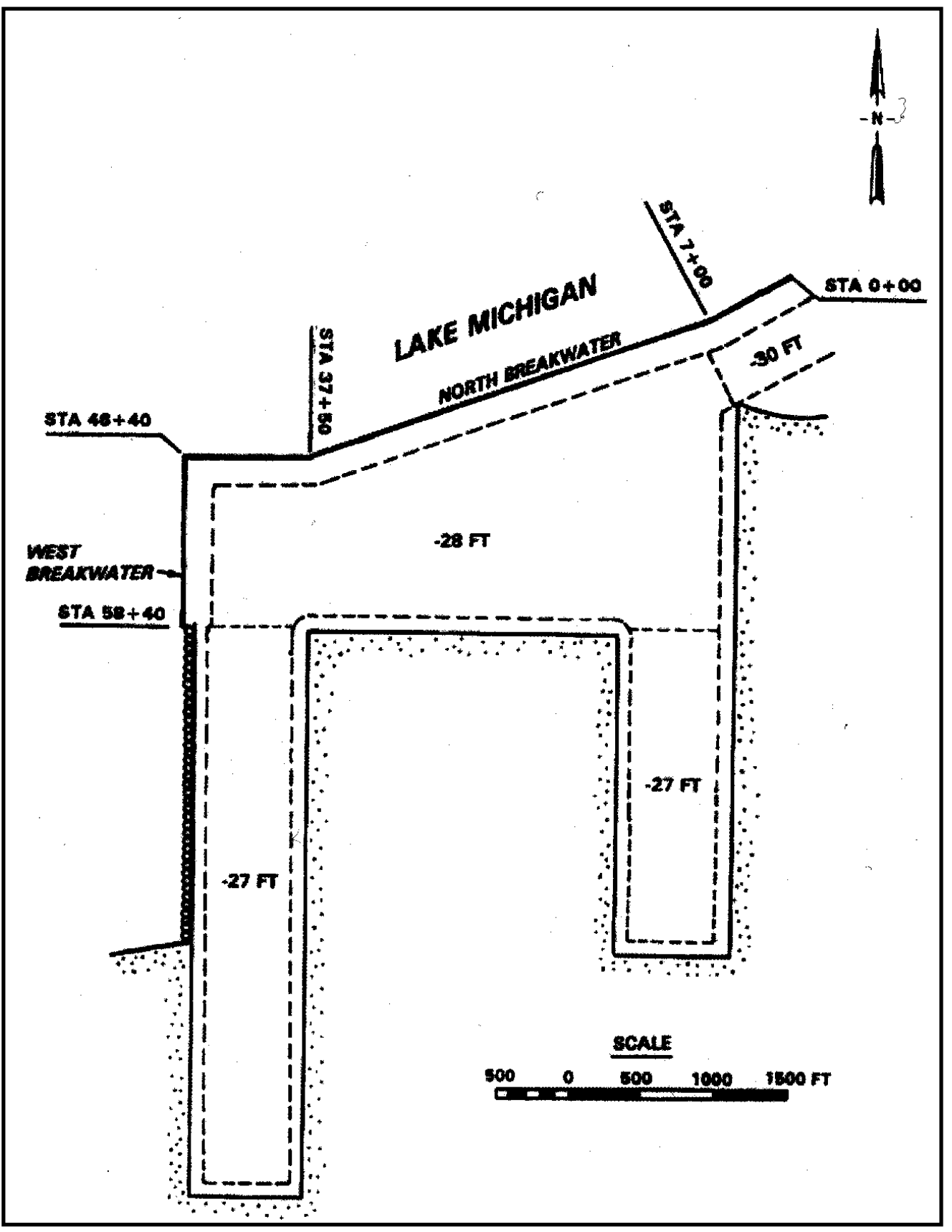

Burns Harbor North Breakwater has required extensive maintenance during its lifetime. In the first 19 years (yr) of existence, an average of 7,640 tons of stone per year was added to the North Breakwater (U.S. Army Engineer District, Chicago 1994). Between 1975 and 1989, 145,117 tons of maintenance stone were placed on the structure.

Meanwhile, damage due to excessive wave action was occurring in the Harbor interior and to vessels moored within the Harbor. Exceedingly 
high cost and maintenance issues resulted in an extensive monitoring effort to evaluate the design process and to identify the causes of excessive wave energy in the harbor (McGehee et al. 1997). New physical model studies conducted at ERDC evaluated possible solutions (Carver and Wright 1995; Acuff and Bottin 1995). As a result of these efforts, a submerged reef breakwater system was constructed between 1995 and 1998, located $75 \mathrm{ft}$ lakeward of the existing North Breakwater (Figure 11).

Figure 11. Layout of submerged reef breakwaters lakeward of existing North Breakwater, Burns Harbor, Portage, IN.

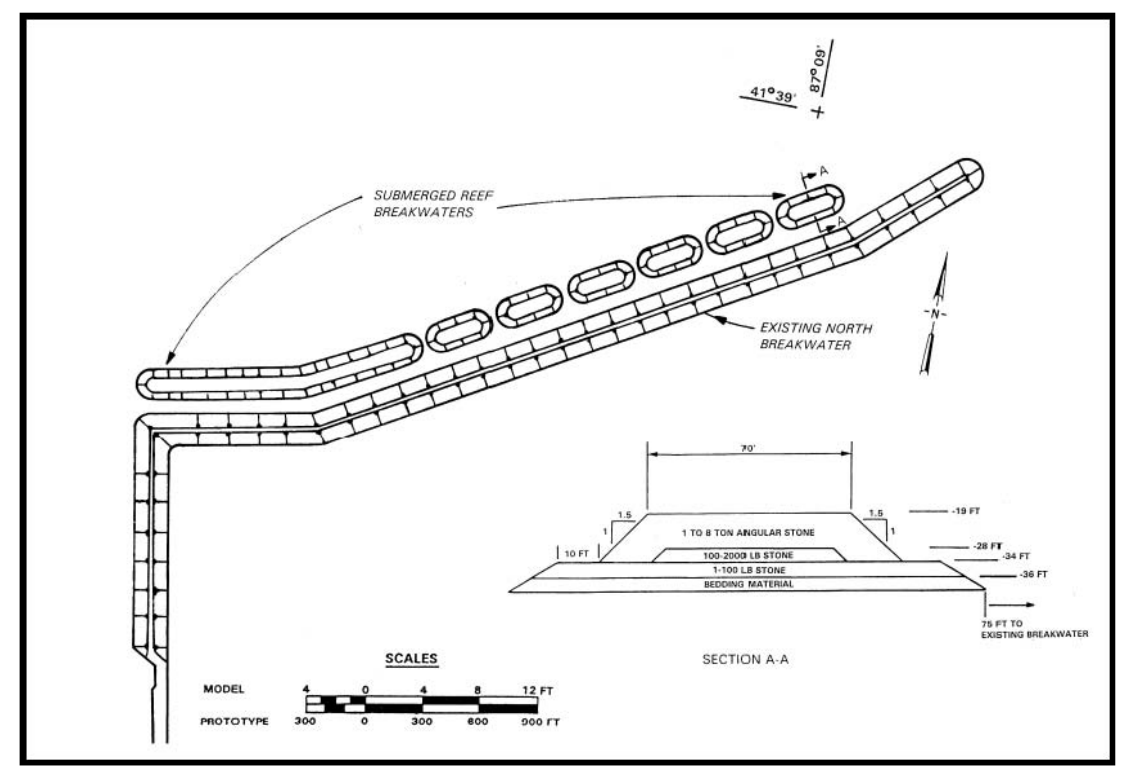

The purpose of this new reef-type structure was to reduce wave energy reaching the existing breakwater and, thereby, reduce breakwater damage and energy transmission into the Harbor. The reef system consists of seven separate segments. The westernmost reef was built 1,450 ft long, and the other six were each $275 \mathrm{ft}$ long (head to head). The structure toes were $25 \mathrm{ft}$ apart, and each had a width of $70 \mathrm{ft}$. They were each constructed at an elevation of - $19 \mathrm{ft}$ lwd. Figure 12 is an aerial photograph of Burns Harbor. 
Figure 12. Burns Harbor, Portage, IN, south shore of Lake Michigan, looking north.

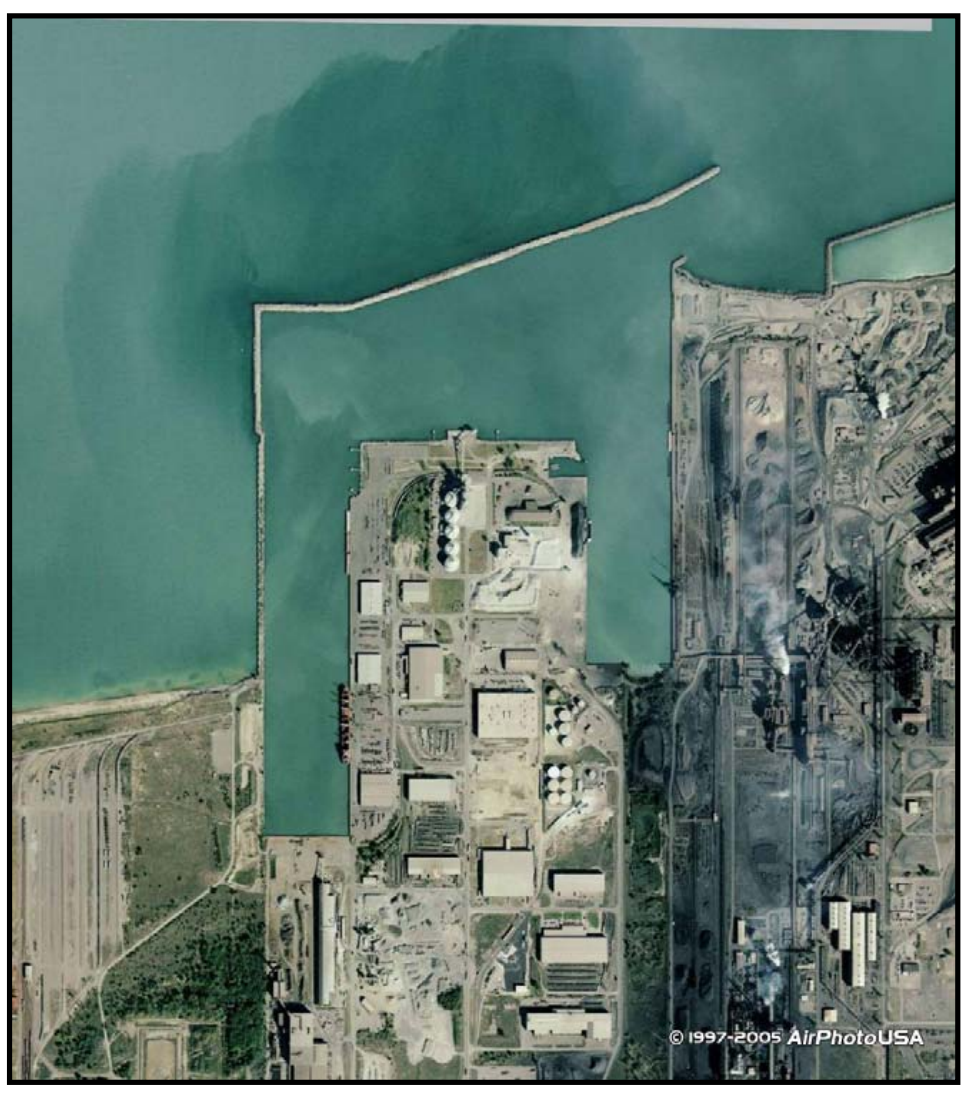

\subsection{Dolos armor units and break types}

In 1963, Eric Merrifield, a South African engineer for East London Harbor on the southern coast of Africa, witnessed a storm remove over half of the Harbor breakwater's solid armor units. Merrifield decided to design an armor unit that would allow for a porous breakwater, resulting in the dissipation of wave energy through the armor. They must be interlocking, affordable, and able to be installed in a random fashion. He designed the dolos (dolosse plural) to look similar to an " $\mathrm{H}$ " with one leg turned 90 degrees (Figure 13). Testing of Merrifield's design was conducted by the South African Counsel for Scientific and Industrial Research in 1965. Dolosse were shown to be more stable than other armor units of the time and were soon used on over 50 structures throughout the world (Pope et al. 1993).

Between the first placement of dolosse on the East London Harbor Breakwater, South Africa, in 1964 and the present, dolosse have been exposed to many different construction and storm conditions. Subsequently, weaknesses in the dolos design have been exposed. The 
slender central sections and long legs produce very high stresses in the central sections of the units. This results in units that break into pieces having much less mass than the original unit. The broken units have little stability and may contribute to the breaking of adjacent units (Turk and Melby 1995).

Figure 13. Various views of a dolos armor unit.

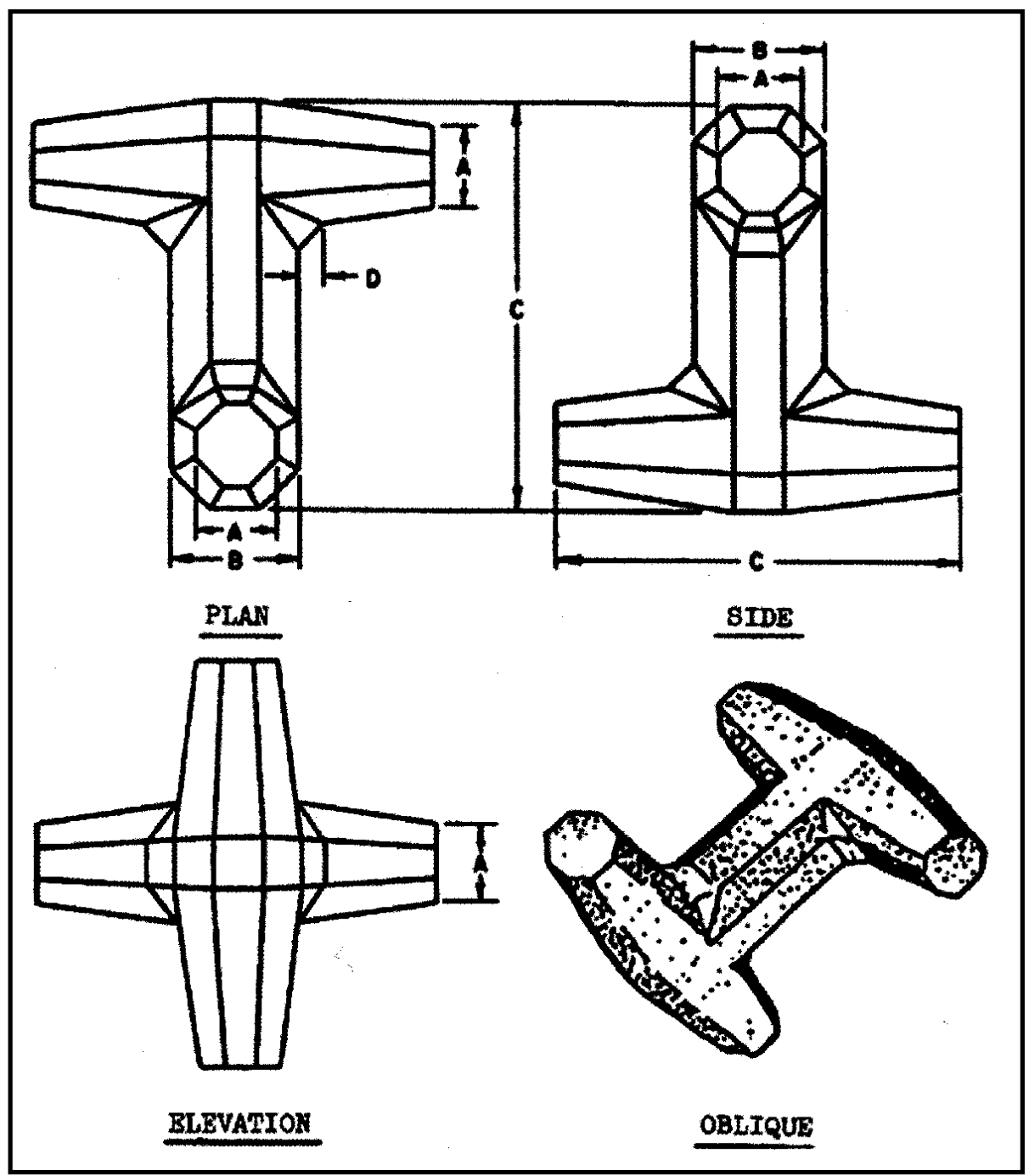

The center section of the dolosse is referred to as the shank while the legs are called flukes. Dolos breaks were characterized according to Melby and Turk (1994) and recorded as one of the following during the walking inspections: (a) mid-shank, (b) shank-fluke (shank broken near one of the flukes), or (c) fluke-shank (fluke broken near the shank). Additional recorded details beyond those given by Melby and Turk included whether the breaks were straight or angled. This would indicate flexure or torsional shear failure. Damage was further specified as cracks, broken fluke tips, 
and pieces. The latter was used to indicate severe breakage where only scattered remnants remained and the broken dolos could no longer be identified other than vicinity. Typically representative views of dolos break types at Cleveland Harbor East Breakwater are shown in Figures 14 through 17.

Figure 14. Example of a dolos angled midshank break.

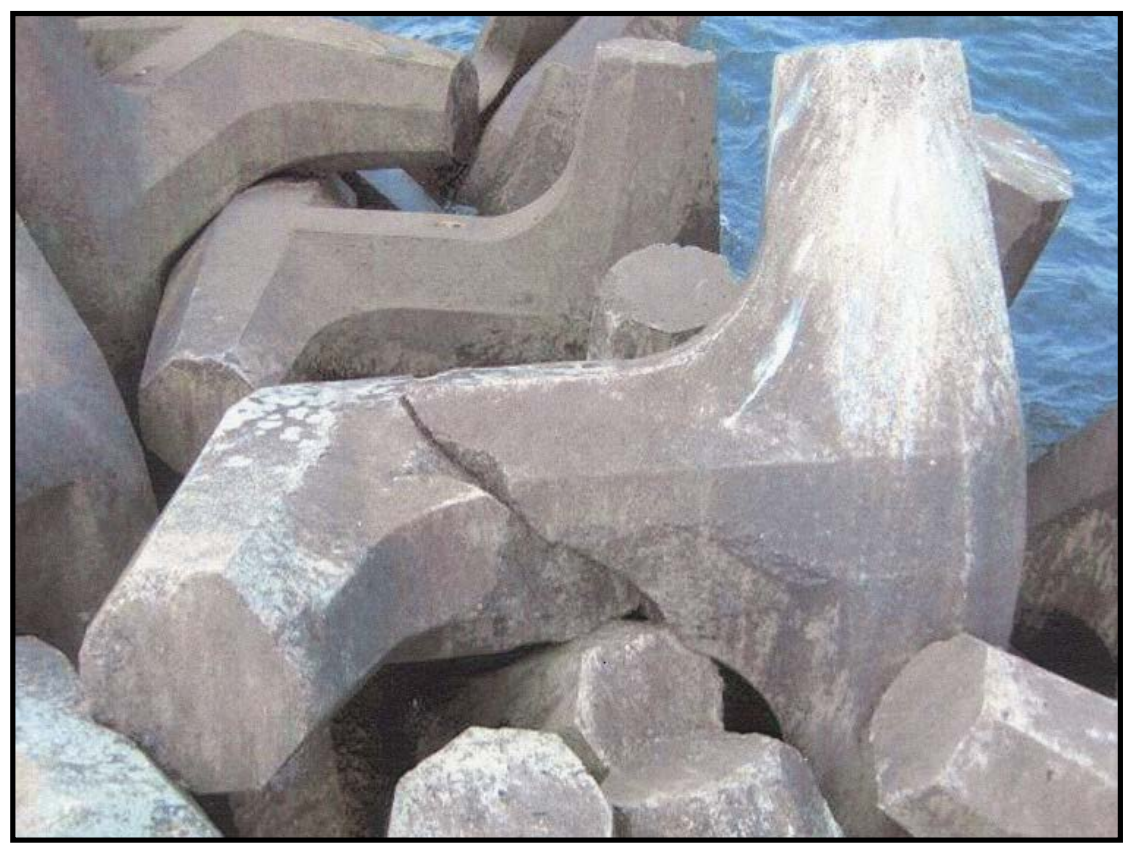

Figure 15. Example of a dolos angled fluke-shank break.

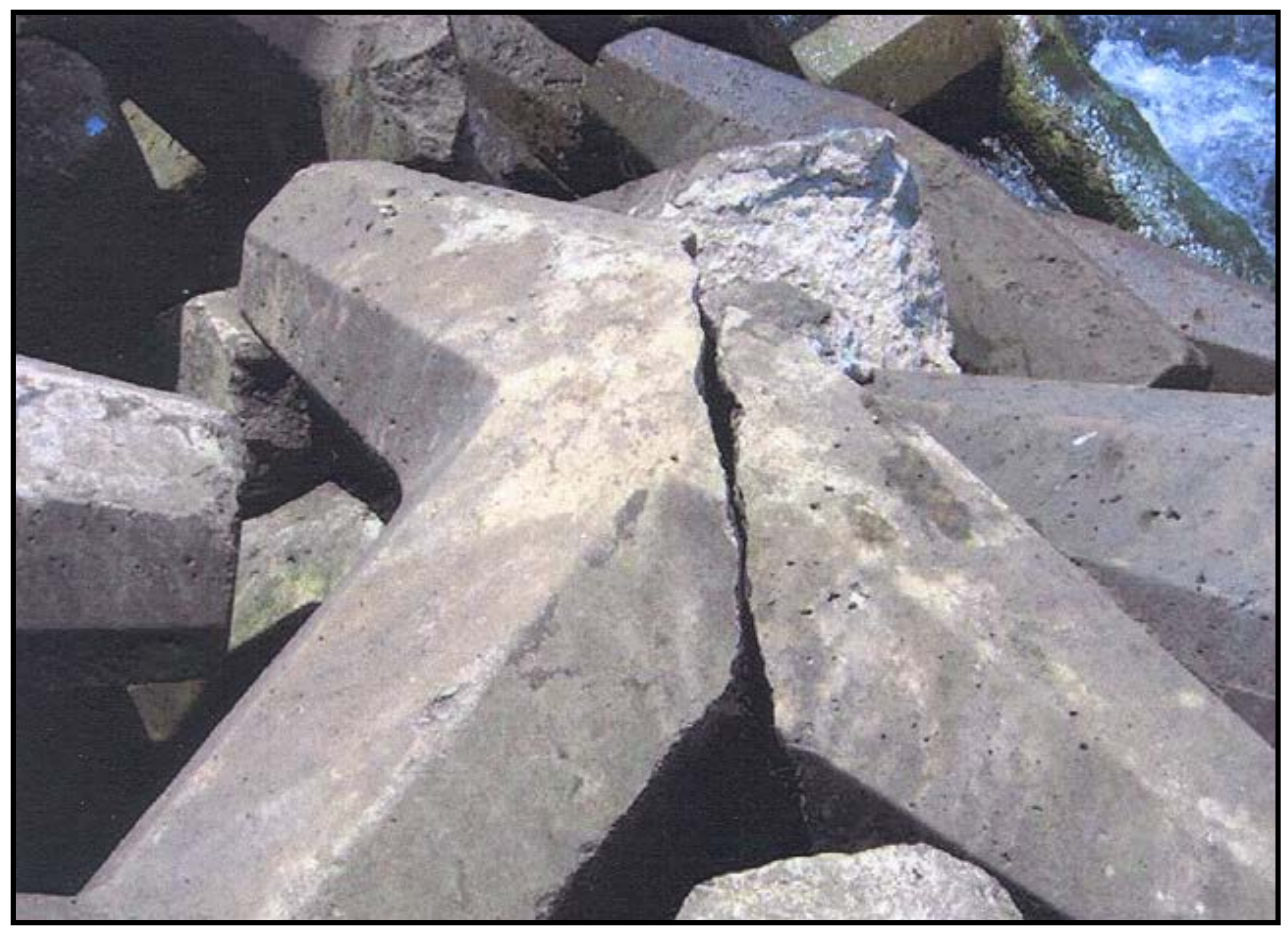


Figure 16. Example of a dolos straight fluke-shank break.

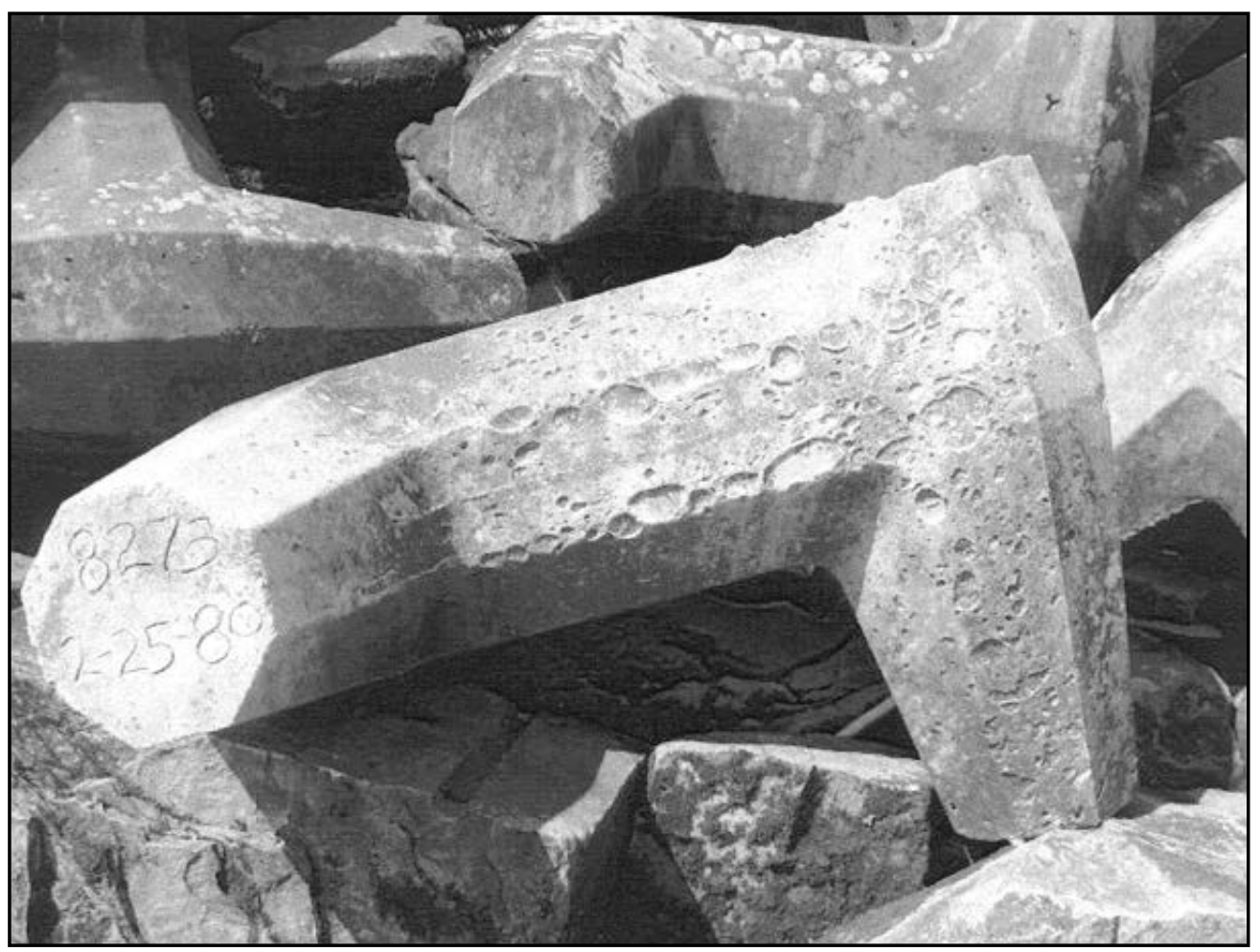

Figure 17. Example of a dolos broken fluke tip.

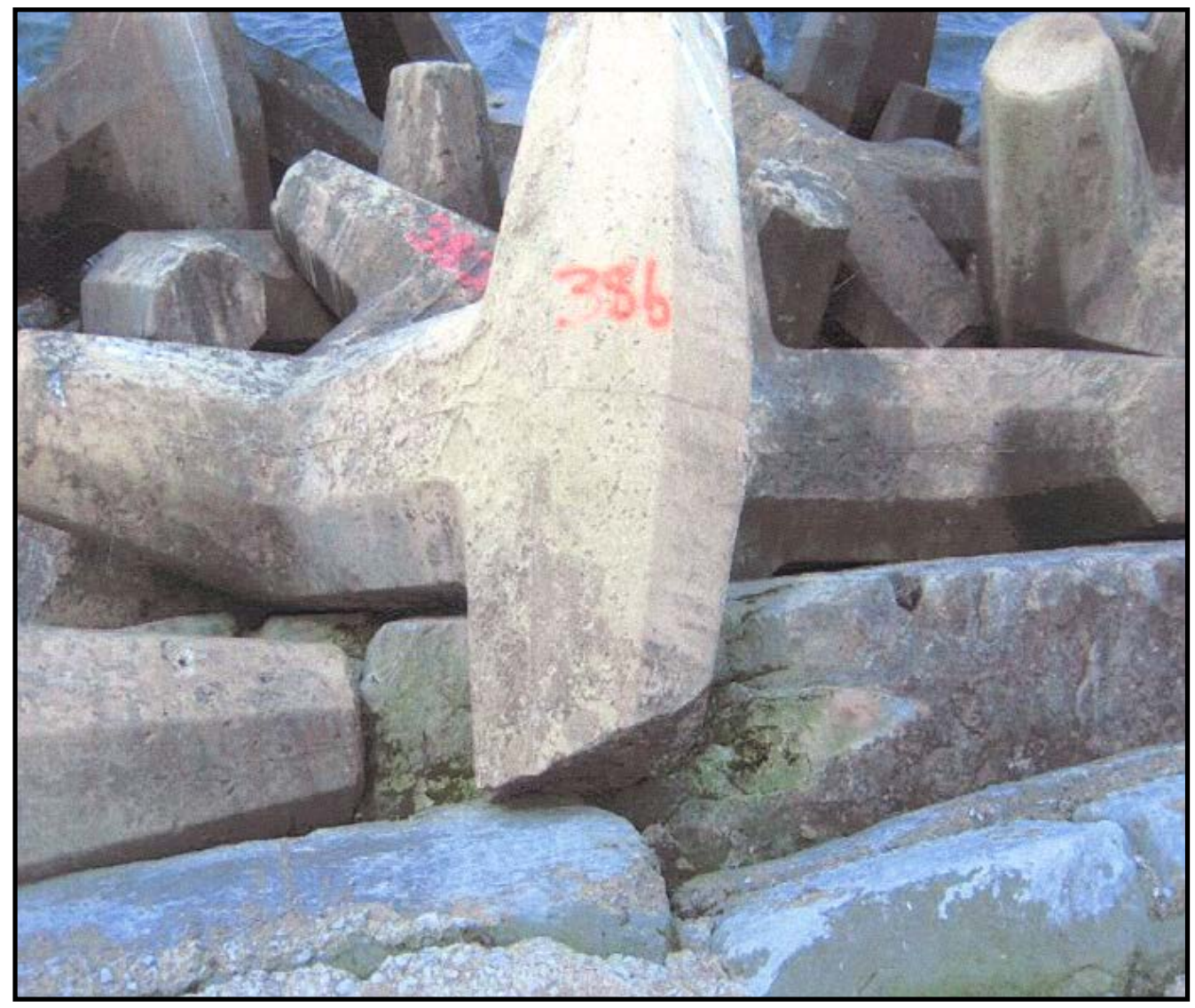




\section{Cleveland Harbor East Breakwater Prior Monitoring}

\subsection{Cleveland Harbor East Breakwater 1980-1985 initial monitoring}

\subsubsection{Dolos armor monitoring}

The first time dolosse were used on an offshore Great Lakes structure was the Cleveland Harbor East Breakwater major dolos rehabilitation project of 1979- 1980. This dolos section of the breakwater, the easternmost 4,400 ft, was selected for monitoring by the MCCP (later MCNP) program in 1980. (The Periodic Inspections work unit did not exist at that time but was initiated in 1993.) The primary purpose of the dolos armor monitoring was to determine the stability of a dolos armored unit cover layer. Additional objectives were to (a) determine wave transmission by overtopping, (b) qualitatively evaluate run-up, and (c) document the effects of ice loading on the stability of dolos units.

Aerial photography, wave and water level data, survey data (to determine above waterline movement), time lapse photography, broken dolos unit inventory, and underwater surveys with both side-scan sonar and diver inspections were used in this comprehensive monitoring program. Method details of each can be found in Pope et al. (1993).

The monitoring program was originally scheduled to extend over a $3 \mathrm{yr}$ time period, but a severe near-design lake storm on 6 April 1982 extended the program for an additional $2 \mathrm{yr}$, until September 1985. The storm resulted in the removal of 65 dolosse surrounding the head of the breakwater and noticeable armor movement and breakage along the trunk. Repairs to the breakwater head occurred in October 1982.

Above-water broken dolos inventories were conducted 10 times during the monitoring period. Records indicates that 692 broken units were documented. Of this number, approximately $60 \%$ of the breakage occurred following the first year of construction and a period surrounding a storm in April 1992 (Figure 18). Angled breaks outnumbered straight breaks, and most breaks were classified as fluke breaks. Of the shank breaks, the number of angled and straight breaks was approximately the same. 
Figure 18. Cumulative number of broken dolos armor units located during 1980-1985 initial monitoring (comprehensive), Cleveland Harbor East Breakwater (after Pope et al. 1993).

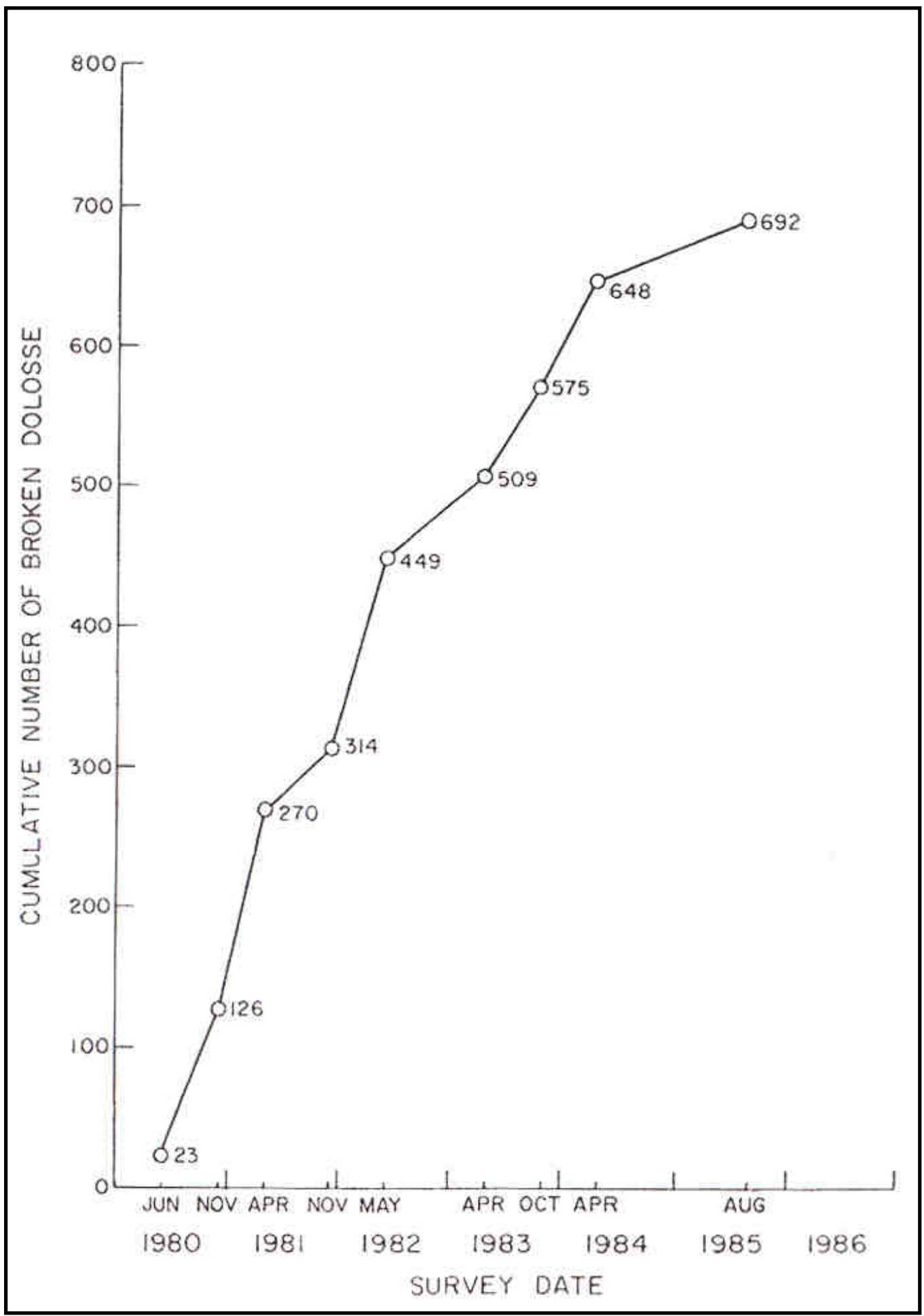

It appeared there was no correlation between lake water levels and the number of armor unit breakage, though the water level may affect the location of damage on the breakwater. Increase in water level during 
storm conditions may result in damage higher up on the structure and explain dolos breakage near the structure's crest. Also, lake water levels at the time of broken dolos surveys will affect the number of armor units visible to the survey team (Pope et al. 1993).

Concurrent with the monitoring effort, two-dimensional (2D) model studies were being conducted at CHL to determine wave stability of dolos and stone rehabilitation designs for the East Breakwater (Markle and Dubose 1985).

Conclusions and recommendations from the initial (1980-1985) dolos armor monitoring of Cleveland Harbor East Breakwater (Pope et al. 1993) included the following:

1. Although the 2-ton dolos armored layer had deteriorated over the years, the breakwater continued to provide the required level of shore protection. Maintenance of the dolos cover had been on an as-needed basis. Repairs, including repositioning and/ or the installation of additional armor units, are required after major storms.

2. Wave reflection off the vertical concrete navigation light foundation at the breakwater head appeared to contribute to the loss of armor units in that area. Dolos armor layers were very porous. Wave energy was transmitted through the dolosse and reflected back upon them, apparently popping them out of place. Additional layers over reflective surfaces may be prudent for highly porous armor units.

3. As evidenced by significant movement and breakage, the 2-ton dolos appeared to be under-designed for the Cleveland Harbor East Breakwater. A 2-D model study also indicated that 4-ton armor units (as opposed to 2-ton) would decrease the probability of movement.

4. During the monitoring period, the 2-ton dolos cover continued to subside and lose elevation. Breakage of armor units also oocurred throughout the monitoring period, but the rate of breakage appeared to decrease slightly toward the end of the monitoring period. Most breakage occurred along the waterline in the active wave zone. Little breakage was noted below the waterline during diving inspections.

5. Aerial photography of the dolos cover proved to be a useful tool during the monitoring program in spite of the fact that the photos were not completely rectified. Photos were used to evaluate qualitative changes in the armor cover. This photography served as the basis for planning maintenance and repair of damage zones during the monitoring period. 
6. Wave gauges were not deployed at Cleveland Harbor during the winter months because of concern that they would be lost to ice. Unfortunately, most severe storms during the monitoring period occurred during the winter. The wave data collected, therefore, were not representative of the most severe storm conditions.

7. Side-scan sonar surveys proved to be a valuable means for obtaining qualitative documentation of the condition of the structure toe and the consistency of the cover layer slope. Combined with diving surveys, the underwater condition of the dolos cover was determined to have several flaws from original construction, including zones of no armor and areas where the toe appeared to be unstable.

8. Since dolos breakage can jeopardize the structure's integrity, dolosse should be designed for "no-rocking" criteria to minimize breakage resulting from movement. This was reported by Melby and Turk (1994) when reviewing past dolos project performance. Consideration also should be given to reinforcement of dolosse in the active wave zone for a deepwater structure, since breakage appeared to be concentrated in this area. Additionally, dolosse should be placed over a stone underlayer rather than against a flat surface to prevent movement caused by wave reflection.

9. The 2-D model study investigation, conducted subsequent to prototype construction, indicated that the dolos cover at Cleveland Harbor would be unstable for wave conditions in excess of $10.5 \mathrm{ft}$. When new breakwater cover concepts are being considered, a model investigation incorporated as part of the design would help in selecting the optimum cover unit. Proper design will minimize repair and rehabilitation costs during the life of these projects.

10. Aerial photography targets and dolosse identified for armor unit surveys at Cleveland ranged from 300 to $900 \mathrm{ft}$ apart. More detail would have been useful in rectifying stereo-pairs. For future monitoring efforts, it was recommended that controls be established to place at least three targets in each photo frame.

\subsubsection{Stone armor monitoring}

Major stone rehabilitations, followed by extensive stone cracking in a relatively short time frame, led to an intensive quality assurance/ quality control (QA/ QC) effort (Marcus 1994). Three armor stone reaches, Reach 1 (sta. 197+65 to sta. 198+65), Reach 2 (sta. 107+50 to sta. 108+50), and Reach 3 (sta. 164+00 to sta. 164+55), each with uniquely different stone characteristics and placements, were chosen for monitoring in 1989, 1990, and 1992, respectively. (The locations of the three reaches can be found in 
Figure 7.) The purpose of armor stone monitoring was to gain a better understanding of stone durability relating to the natural and man-made causes for early stone degradation. Details of methods and data can be found in Bottin et al. (1995).

Results of the initial (1989, 1990, and 1992) stone armor monitoring at Cleveland Harbor East Breakwater (Bottin et al. 1995) included the following:

1. Detailed geologic cracked stone investigations performed during breakwater walking inspections proved to be a successful method for observing minute crack formation and crack damage development otherwise missed by routine boat or aerial observation.

2. The sequential photographing of individual stone damage on an annual basis, with cracks and crack damage spray painted and recorded, provided viable, visual documentation of the stone cracking problem occurring on the breakwater.

3. Annual photographic sequences and photographic comparisons proved to be a highly successful tool in assisting with quantification of damage type over time.

4. Breakage of armor stone occurred along the entire profile of the structure; however, most severe breakage (where displacement of stone pieces occurred) took place along the waterline, in theactive wave zone.

5. Early indications suggest that enhanced QC/ QA stone inspections yield better end-quality products than the current standard Corps QC/ QA inspections.

6. As evidenced by continued cracking and crack damage advancement, a severe problem existed on the above-water armor stone on the Cleveland Harbor East Breakwater. Further studies using the completed database may providenew insight on the future of stone durability in coastal structures.

\subsection{Cleveland Harbor East Breakwater 1993 Periodic Inspections monitoring}

In J une 1993, monitoring of the Cleveland Harbor East Breakwater was conducted by the recently created (1993) Periodic Inspections work unit of the MCNP. The objectives were to re-examine the breakwater to determine changes that had occurred since the MCCP program ended in 1985 and to establish above-water armor unit baseline data upon which long-term stability could be defined through periodic inspections (Bottin et al. 1995). 
The 1993 inspection included the easternmost 4,400 ft dolos section and three representative stone sections selected by CELRB. The stone sections included the previously studied Reaches 1, 2, and 3, with adjacent additions more than doubling the area that was studied in previous years. Reach 1 included a new $135 \mathrm{ft}$ section (sta. 198+65 to sta. 200+00) in addition to the adjacent historical reach study area (sta. $197+65$ to sta. 198+65) monitored from 1989-1992. Reach 2 involved monitoring an additional $100 \mathrm{ft}$ section (sta. 108+50 to sta. 109+50) adjacent to the historical reach area (sta. $107+50$ to sta. 108+50) monitored from 1990-1992. Reach 3 entailed monitoring $180 \mathrm{ft}$ of the structure (sta. $163+60$ to sta. 165+40) as opposed to $55 \mathrm{ft}$ (sta. 164+00 to sta. 164+55) monitored in 1992.

Low-altitude aerial photography, target and ground surveys, photogrammetry, and walking broken-armor-unit surveys were used in this comprehensive monitoring program. Method details of each can be found in Bottin et al. (1995).

A ground survey and Global Positioning System (GPS) control surveying were used to establish monuments (Figure 19) on land and on the cap of the breakwater to serve as horizontal and vertical control points. Ground

Figure 19. Example of a survey monument on Cleveland Harbor East Breakwater.

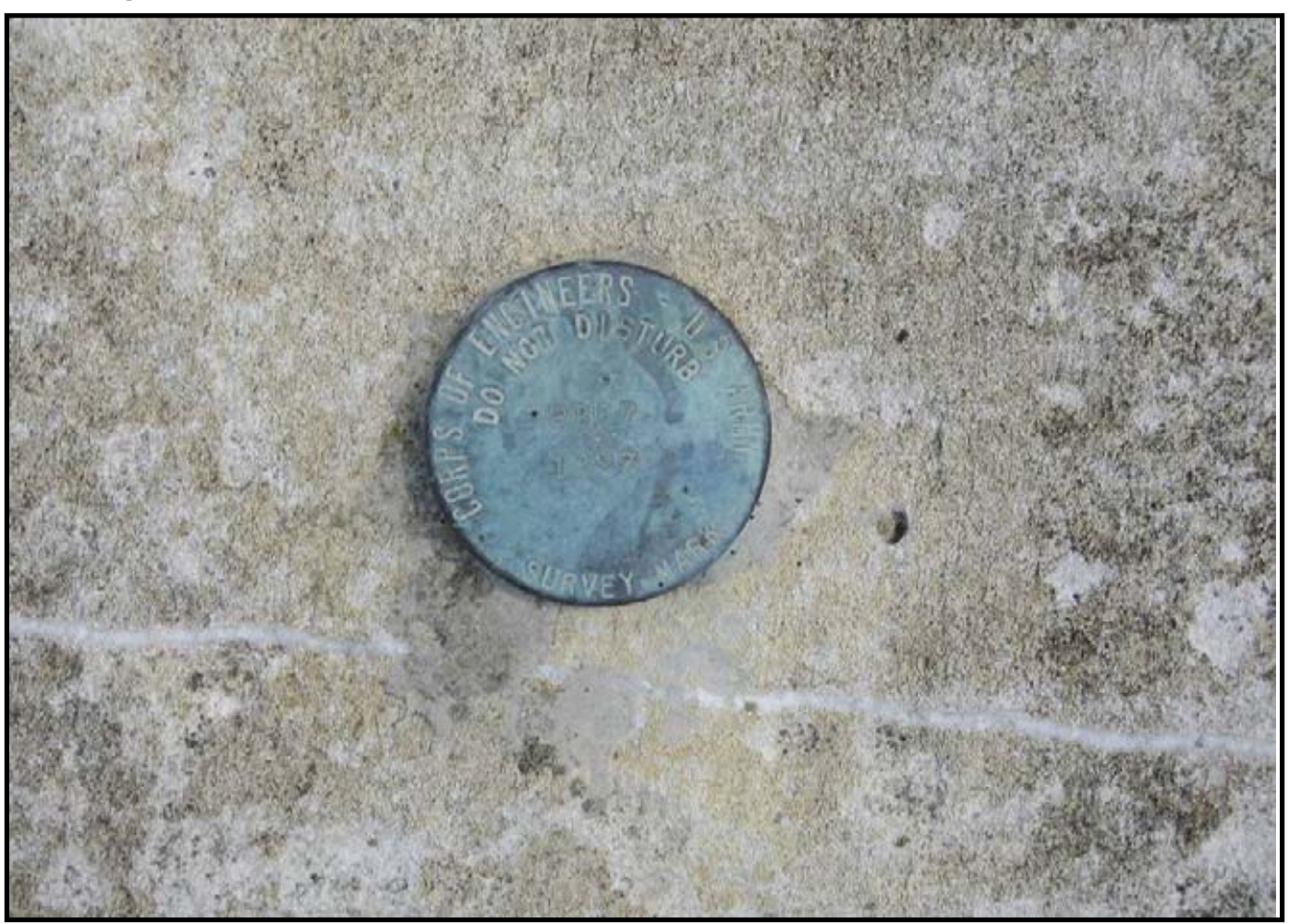


surveys were referenced to known National Geodetic Survey Stations 1702 and G321. GPS coordinates were assigned to the existing monuments 27 , 808, 809, 810, and 813, and to newly established monuments RBD1 through RBD15, located at approximately $500 \mathrm{ft}$ intervals.

Horizontal Planes are based on the Ohio State Plane Coordinated System, and all elevations are referenced to North American Vertical Datum 1988 (NAVD88). Monument positions for the J une 1993 are listed in Table 1.

Table 1. Monument positions for 1993 survey of Cleveland Harbor East Breakwater.

\begin{tabular}{|c|c|c|c|c|c|}
\hline Monument & Easting & Northing & $\begin{array}{l}\text { Elevation, } \\
\text { NGVD88 (ft) }\end{array}$ & Station, (ft) & $\begin{array}{l}\text { Offset from } \\
\text { Center Line, } \\
\text { (ft) }\end{array}$ \\
\hline 1702 & 2190621.17 & 672734.83 & 583.5 & $118+10.56$ & 3303.415 \\
\hline G321 & 2205531.66 & 683682.4 & 583.33 & $303+03.48$ & $6267.82 S$ \\
\hline 27 & 2187673.58 & 674633.95 & 577.84 & $106+34.82$ & 0 \\
\hline 808 & 2196747.34 & 681624.86 & 577.38 & $220+89.34$ & $0.49 S$ \\
\hline 809 & 2199140.85 & 683469.78 & 578.75 & $251+11.36$ & $0.04 \mathrm{~N}$ \\
\hline 810 & 2200824.79 & 684767.24 & 583.53 & $272+37.16$ & 0 \\
\hline 813 & 2188107.18 & 674968.53 & 579.45 & $111+82.50$ & $0.38 \mathrm{~N}$ \\
\hline RBD1 & 2200613.46 & 684604.44 & 579.04 & $269+70.40$ & $0.02 \mathrm{~N}$ \\
\hline RBD2 & 2200222.37 & 684303.05 & 578.03 & $264+76.65$ & $0.01 \mathrm{~S}$ \\
\hline RBD3 & 2199845.75 & 684012.92 & 578.52 & $260+01.24$ & $0.04 \mathrm{~N}$ \\
\hline RBD4 & 2199449.74 & 683707.77 & 579.09 & $255+01.30$ & $0.03 . \mathrm{N}$ \\
\hline RBD5 & 2199053.71 & 683402.56 & 578.63 & $250+01.30$ & $0.02 S$ \\
\hline RBD6 & 2198657.31 & 683097.03 & 577.71 & $245+00.82$ & 0.095 \\
\hline RBD7 & 2198253.45 & 682785.74 & 577.76 & $239+90.91$ & $0.18 \mathrm{~S}$ \\
\hline RBD8 & 2197863.2 & 682484.95 & 577.27 & $234+98.20$ & $0.25 S$ \\
\hline RBD9 & 2197468.63 & 682180.77 & 578.26 & $229+99.99$ & 0.385 \\
\hline RBD10 & 2195073.31 & 680342.83 & 578.56 & $199+80.80$ & $5.73 \mathrm{~S}$ \\
\hline RBD11 & 2194801.37 & 680130.05 & 578.9 & $196+35.52$ & $3.16 \mathrm{~S}$ \\
\hline RBD12 & 2192512.87 & 678361.47 & 579.95 & $167+43.27$ & $0.99 S$ \\
\hline RBD13 & 2192165.53 & 678100.29 & 576.46 & $163+08.72$ & $4.12 \mathrm{~N}$ \\
\hline RBD14 & 2187929.05 & 674831.07 & 578.67 & $109+57.50$ & $0.22 \mathrm{~N}$ \\
\hline RBD15 & 2187710.78 & 674662.65 & 578.55 & $106+81.81$ & $0.03 N$ \\
\hline RBD16 & 2194043.51 & 678211.45 & 582.06 & $178+64.17$ & $1054.07 \mathrm{~S}$ \\
\hline
\end{tabular}


The J une 1993 broken armor unit monitoring of the dolos section indicated 782 broken/ cracked dolos above the water line. Forty-eight of these had multiple breaks. Only 7 of the 782 were 4 -ton units. A distribution of damaged dolos relative to station number can be seen in Figure 20.

Figure 20. Distribution of broken dolos armor units along Cleveland Harbor East Breakwater relative to station number, June 1993 monitoring (after Bottin et al. 1995).

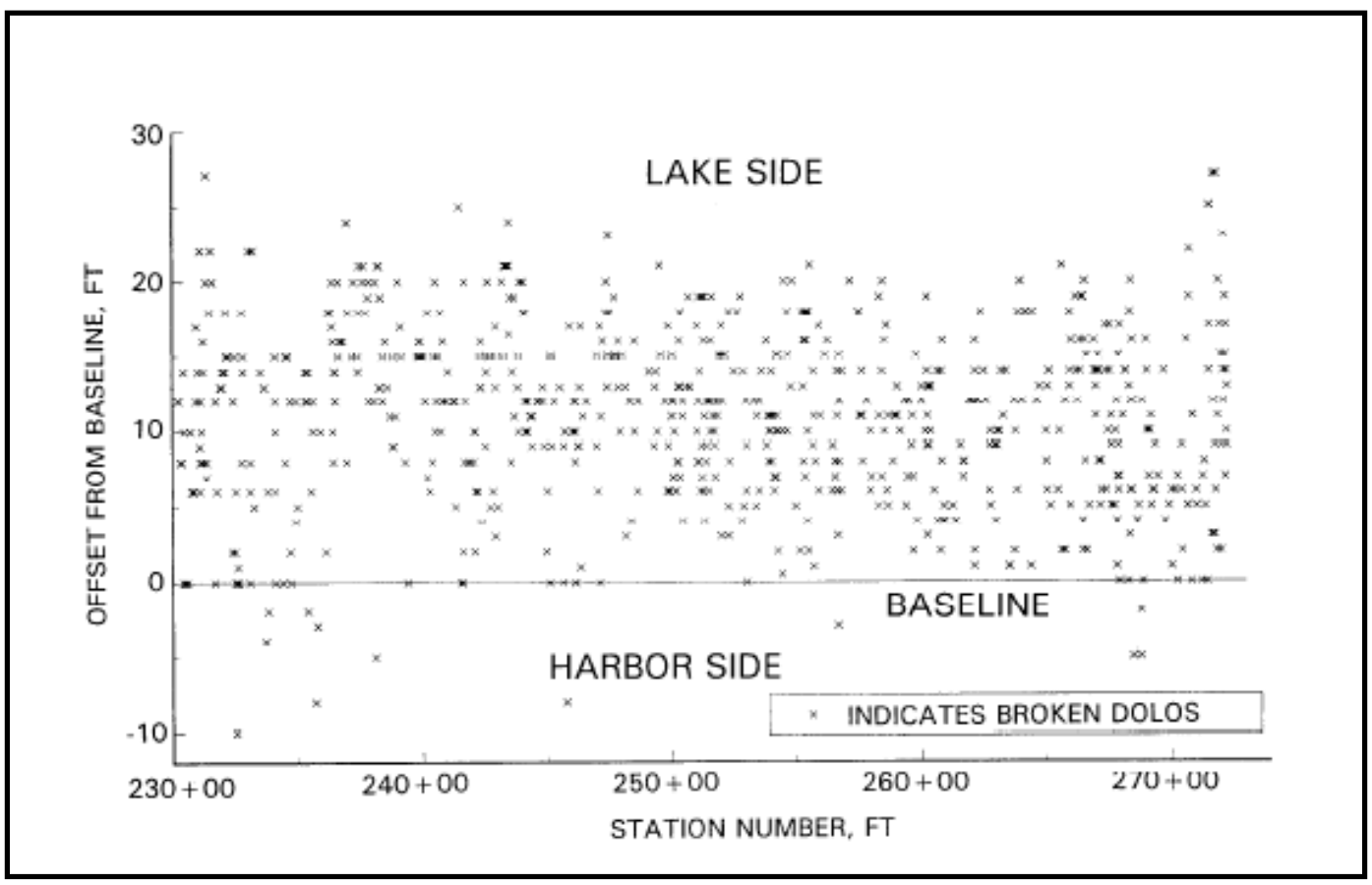

The broken armor unit monitoring for the stone armor was subdivided into the three reach areas and was summarized by Bottin et al. (1995) as follows:

- Reach 1(sta. 197+65 to sta. 200+00): The armor consists of 9- to 20-ton Dolomite Limestone on 1V:1.5H side slopes. One hundred and forty stones were fully documented. Of the previously inspected 59 stones, 10 stones showed no new damage while increased crack damage was noted for the other 49. New cracking seemed to occur randomly. Sixty-one of the 89 newly monitored stones revealed significant cracking (68.5 percent). Seventy-four percent (110 of 148) of above-water stones for the entire 235-ft study reach contained significant damage. The stone damage was largely attributed to blast fractures, and to the geologic composition the quarry used.

- Reach 2 (sta. 107+50 to sta. 109+50): For Reach 2, the same stone sizes and slopes were used as on Reach 1 . The difference was an 
intensive QA/ QC effort conducted prior to construction as a result of the high percentage of damage to Reach 1 . One hundred and twentynine 9- to 20-ton Dolomite Limestone armor stones were documented for the entire 200- $\mathrm{ft}$ section. Only 24 of the 129 (19 percent) stones were considered unsatisfactory because of significant cracking compared to an 18 percent unsatisfactory rate recorded on the original Reach 2 (sta. 107+50 to sta. 108+50) between 1990 and 1992. This suggests that the damage had leveled off, and that the QA/ QC effort had been successful.

- Reach 3 (sta. 163+60 to sta. 165+40): In 1992, sta. 158+00 to sta. $170+00$ and sta. $218+00$ to sta. $224+00$ were rehabilitated. This included the installation of 4.3- to 9.6-ton Dolomite Limestone from a different quarry than used for Reaches 1 and 2 . These were placed using a $1 \mathrm{~V}: 2 \mathrm{H}$ slope. The smaller stone and flatter slope were used with the intention of improving stone durability. Standard acceptance procedures, not the enhanced QA/ QC, were used in the selection of stone. The initial Reach 3 monitored in 1992 was only $55 \mathrm{ft}$ long from sta. $164+00$ to sta. $164+55$. The 1993 monitoring effort increased the area to 180 -ft section. Here, 152 above-water stones were monitored. Of the 152 stones documented, 35 (23 percent) had significant cracks less than two years after placement. Twenty-eight stones had damage attributed to blasting fractures.

\subsection{Cleveland Harbor East Breakwater 1997 Periodic Inspections walking inspection}

In 1996, an HQUSACE program review requested that structures studied during past MCNP efforts be revisited to determine how they are performing in their respective environments. The monitoring effort was designed to be expedient and low cost. There would be no instrumentation or detailed data but rather walking inspections and/ or boat surveys focusing on the generalities of structures. Armor positions were compared to previous aerial photographs when applicable. Obvious voids and settlements were noted, and structure photographs were recorded. Subsequent references to walking surveys or walking inspections refer to this type of monitoring based on the 1996 HQUSACE program review.

The Cleveland Harbor East Breakwater was selected as one of 14 sites to be visited for this effort and was inspected in October 1997. 
Results of the walking inspection and suggestions are summarized by Bottin and Tolliver (1999) as follows:

Inspection of the Cleveland Harbor East Breakwater, $\mathrm{OH}$, indicated that the structure had changed little since the previous survey of 1993. Comparison of armor unit positions revealed that most were in the same locations. Even fragments of broken units were in the same positions. Apparent armor unit movement was observed at only one location on the breakwater. Numerous broken units were observed but verified as being broken during the 1993 survey. The structure is in fair-to-good condition, and appears to be functioning well. It should be inspected periodically, and particularly after storm events.

\subsection{Cleveland Harbor East Breakwater 2004 Periodic Inspections walking inspection}

In J une 2004, a walking inspection of the Cleveland Harbor East Breakwater was conducted. Results and recommendations are summarized by Bottin et al. (2004) as follows:

Inspection of the Cleveland Harbor East Breakwater, $\mathrm{OH}$, indicated overall that the structure armor unit (dolosse) positions had not changed significantly since the previous inspection. Several voids [Figure 21] and low areas were noted, however, on the sea side of the breakwater slope as well as an area of subsidence on the crest. Excessive vegetation also was noted on some areas of the structure, and numerous broken armor units were observed, most of which had been noted as broken during the previous surveys. The structure was in fairto-good condition, and appeared to be functioning well.

Consideration should be given to placing additional armor units in the voids and low areas during scheduled maintenance, and to removing the overgrown vegetation. The breakwater should be inspected periodically, particularly after storm events. It has been 11 years since the structure was formally monitored under the MCNP program. A photogrammetric survey should again be conducted to quantify armor unit movement, and analyze the armor cover layer over this time frame. 
Figure 21. Example of void on lake side of Cleveland Harbor East Breakwater between sta. $230+40$ and sta. $230+70,2004$ walking inspection.

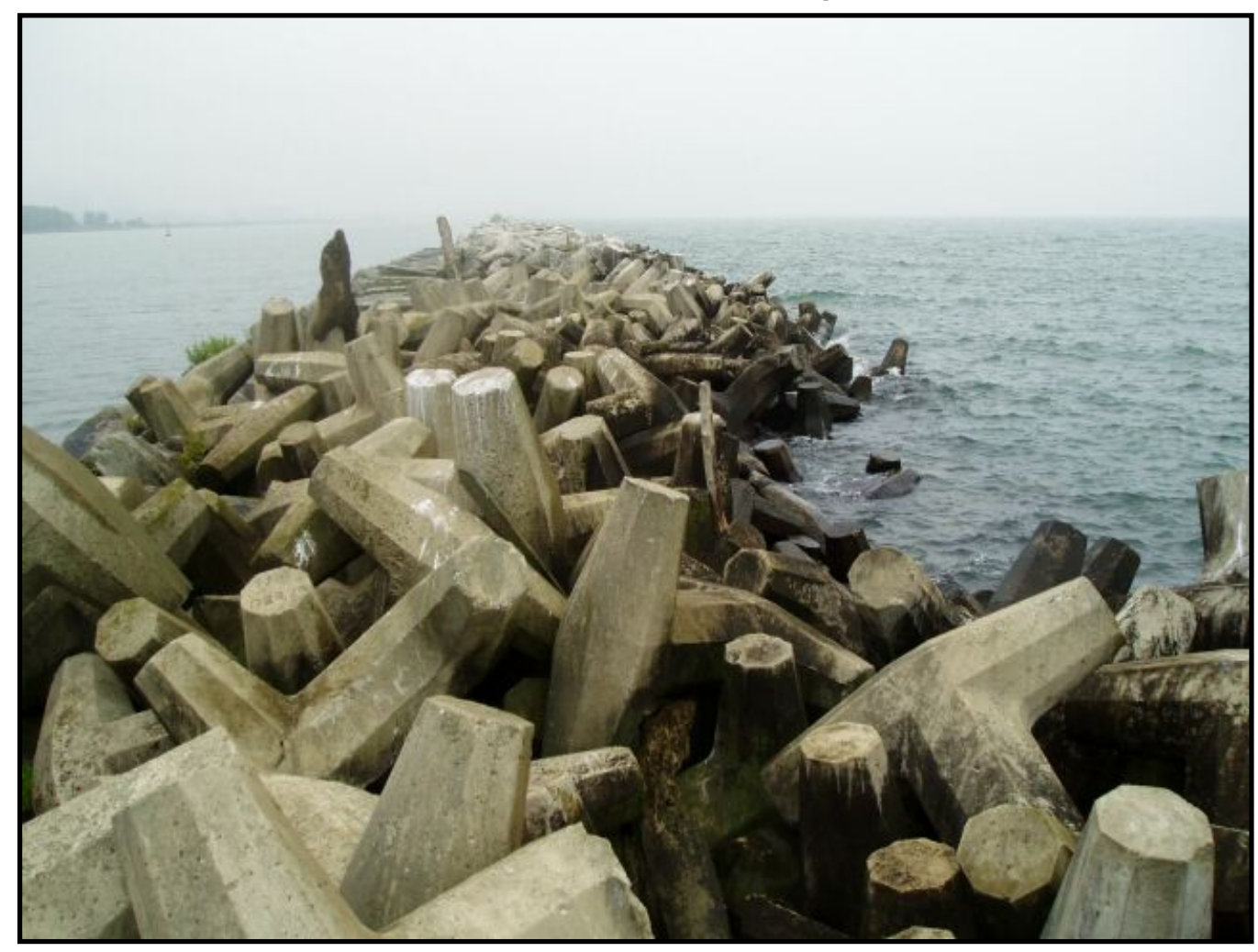




\section{Burns Harbor North Breakwater Prior Monitoring}

\subsection{Burns Harbor North Breakwater 1985-1992 initial monitoring (comprehensive)}

Burns Waterway Harbor North Breakwater was selected for an intense monitoring effort through the MCCP program in 1984. The monitoring was conducted during the period 1985- 1992. The primary purposes were to determine the cause of loss of crest elevation of the breakwater and to evaluate excessive wave conditions in the harbor. The approach of the monitoring effort was to (a) evaluate the design process, (b) identify the causes of complaints of excessive wave energy by harbor users, and (c) determine the causes for frequent necessary maintenance requirements. A comprehensive historical review and characterizations of the breakwater foundation, breakwater stability, and waves on both the inside and outside of the harbor were conducted as part of the monitoring effort.

Some of the methods employed included site inspections, dive inspections, side-scan sonar surveys, geotechnical data collection, and wave and water level data collection. Details of the initial monitoring conducted during 1985- 1992 can be found in McGehee et al. (1997). Results of this initial monitoring are summarized in Hales and Richie (2004) as follows:

Operational problems frequently occurred in the harbor. Prototype wave gauging at the site revealed an approximate 30 percent transmission coefficient for the breakwater. This was attributed to the structure's high porosity. Therefore, when incident waves exceed $10 \mathrm{ft}$ (an annual occurrence), the 3-ft operational criteria in the harbor were exceeded. The harbor was functioning, though not to the satisfaction of the users.

Analysis of design procedures used for Burns Harbor revealed that the design wave and water level were severely underestimated prior to original breakwater construction. Additionally, a 3-D model investigation under-predicted wave heights throughout the harbor, because it used an impermeable breakwater (as opposed to a porous structure). A 2-D model also over-predicted armor stone stability 
and under-predicted transmission. These model investigations were performed in the early 1960s.

The structure was determined to be under-designed, principally due to underestimation of the wave climate in Lake Michigan. An improved hindcast, supplemented with wave data, produced an updated extremal analysis. The original $13-\mathrm{ft}$ design wave was determined to be a 2-year event (McGehee et al. 1997).

The breakwater had experienced considerable damage over its life, but no single storm or specific event has caused loss of a section below the waterline. The loss of armor stones on the crest was assumed to be caused by high wave action. The structure had experienced waves larger than its design condition on numerous occasions. Harbor-side armor damage was assumed to be due primarily to overtopping and/ or transmitted waves.

The crest elevation of the breakwater was $1.0 \mathrm{ft}$ below its design elevation, on the average. There was evidence that the foundation may not have been constructed appropriately, thus causing greater settlement of the breakwater than anticipated. Excavation of clay from beneath the breakwater was placed lakeward of the structure. Clay deposition piles noted during the geotechnical portion of the monitoring make it believable that some of the clay washed back into the trench prior to construction. Additionally, the presence of large sand piles on the lake bed indicated that a significant portion of the sand backfill material for the trench may have been placed lakeward of the proposed structure location, and not actually placed in the trench.

The structure may have experienced greater than anticipated settlement, though the difficulty of evaluating historical survey data and variation in settlement along the structure hampers attempts to estimate the actual settlement. Both the original geotechnical design and a subsequent reanalysis predicted average settlement of about $1 \mathrm{ft}$. However, statistical analysis of the survey data suggests the structure has settled an average of about $2.0 \mathrm{ft}$. This settlement represents "loss" of armor stone on the order of 100 kilotons, roughly equivalent to the amount of repair stone placed on the structure over its life. 
Alternatives for the reduction of maintenance of the breakwater were to (1) add larger stone and/ or increase the angle of the slopes, (2) add a concrete cap to the structure to improve stability of the crest, or (3) place a protective structure (reef-type structure well below the water level) in front of the existing breakwater. An economic analysis was conducted to determine which alternative(s) would result in reduced overall costs. (Alternative 3 was selected subsequent to this 1985 thru 1992 monitoring of the site, and was constructed in the prototype).

The cut stone armor used in the breakwater exhibited a wider variance in stability than associated with typical rubble mounds. The result is a highly variable pattern of damage on the structure. The stability of cut stone armor is more sensitive to placement technique than other types of armor. Weathering of the armor resulted in some breakage, but not a significant amount.

A 3-D model study used to plan the harbor resulted in an ineffective entrance design. That study did not accurately predict wave conditions in the harbor because it assumed all wave energy would enter the harbor through the entrance (impermeable breakwater; no overtopping), and also it underestimated the design wave.

A 2-D model study used to design the breakwater cross-section underestimated wave transmission, possibly caused by settlement of the structure and subsequent repairs that resulted in a more porous structure. The 2-D model study appeared to predict the stability, but did not accurately predict the harborside damage that was approximately equal to the lakeside damage over the life of the structure.

The functional requirements of the project changed since design because of an increase in barge traffic in the harbor. Most of the user complaints regarding operations could be traced to one facility, the grain dock on the north wharf which was constructed with a vertical sheet-pile face. Measurements verified that reflection caused wave conditions in front of the dock to be twice the height of waves in the open area of the harbor. This facility with a vertical sheet-pile face was not anticipated in the design phase. 


\subsection{Burns Harbor North Breakwater 1994-1995 Periodic Inspections monitoring (base conditions)}

During the period November 1994-J uly 1995, monitoring of the Burns Harbor North Breakwater was conducted as part of the MCCP (presently MCNP) program under the Periodic Inspections work unit that had been initiated in 1993. Purposes of the monitoring by Bottin and Matthews (1996) included the following:

- develop methods using limited land-based surveying, aerial photography, and photogrammetric analyses to assess the long-term stability response of the stone armor layer on the Burns Harbor North Breakwater

- conduct land surveys, broken armor stone inspections, aerial photography, and photogrammetric analyses to

o test and improve developed methodologies, and accurately define armor unit movement above the waterline

o establish base condition for the North Breakwater's armor units so that this structure could be remonitored in the future under the Periodic Inspections work unit.

Accomplishments included (a) establishing targets and photo control points for aerial photography and photogrammetry, (b) conducting ground surveys using existing monuments (similar to Cleveland Harbor East Breakwater monuments, Figure 19) to serve as horizontal and vertical reference points, and (c) performing a detailed walking survey of the broken stone armor units.

Details of the J uly 1995 Periodic Inspections monitoring of the 4,640 ft structure were summarized by Bottin and Matthews (1996) as follows:

Each broken armor stone was identified and photographed, and its location relative to breakwater station and distance from a baseline was recorded. The baseline was approximately the centerline of the structure. Armor stones with hairline cracks were not counted; only those that were cracked all the way through were included. The lake level was $+2.0 \mathrm{ft}$ lwd.

The survey revealed a total of 165 broken or cracked armor stones above the waterline. Of these, 26 were located along the breakwater 
crest, 95 on the lakeside slope, and 44 on the harbor side slope. No broken armor stones were observed around the head of the structure. Broken stones occurred along the entire North Breakwater trunk but, in general, high concentrations were found along the eastern-most portion of the structure. About 50 percent of the broken units (82 units) were located on the eastern one-third $(1,500 \mathrm{ft})$ of the structure. The majority of the broken armor stones along the structure (57 percent) were located on the lake-ward face of the structure in the active wave zone. About 16 percent of the broken armor units were on the crest of the breakwater, and 27 percent were on the harbor side of the structure. The detailed data obtained during this walking survey will allow for an accurate indication of any new breaks that may occur prior to the next structure re-survey.

\subsection{Burns Harbor North Breakwater 1999 Periodic Inspections walking inspection}

In August 1999, a Periodic Inspection was conducted of the North Breakwater (Bottin and Tibbetts 2000) to compare with data obtained during the previous Periodic Inspection of 1994- 1995 (Bottin and Matthews 1996). Targets and control points are shown in Figure 22. Prior to this monitoring, construction of the submerged, segmented reef breakwater was completed on the lake side of the North Breakwater. The 1999 effort established new baseline data to determine future effectiveness of the reef system relative to damage of the existing North Breakwater.

Results of the August 1999 monitoring of Burns Harbor North Breakwater by Bottin and Tibbetts (2000) are summarized by Hales and Richie (2004) as follows:

Results indicated continued loss of structure elevation.

Approximately 46 percent of the total length of the breakwater was below the design crest elevation of +14 ft versus 24 percent in 1995. Also, about 11 percent of the structure was below an elevation of $+12 \mathrm{ft}$ in 1999 versus 4.6 percent in 1995. Both surveys indicated crest width along the breakwater narrower than design and slopes on the harbor side of the structure steeper than design. 
Figure 22. Control points for Burns Harbor North Breakwater August 1999 walking inspection.

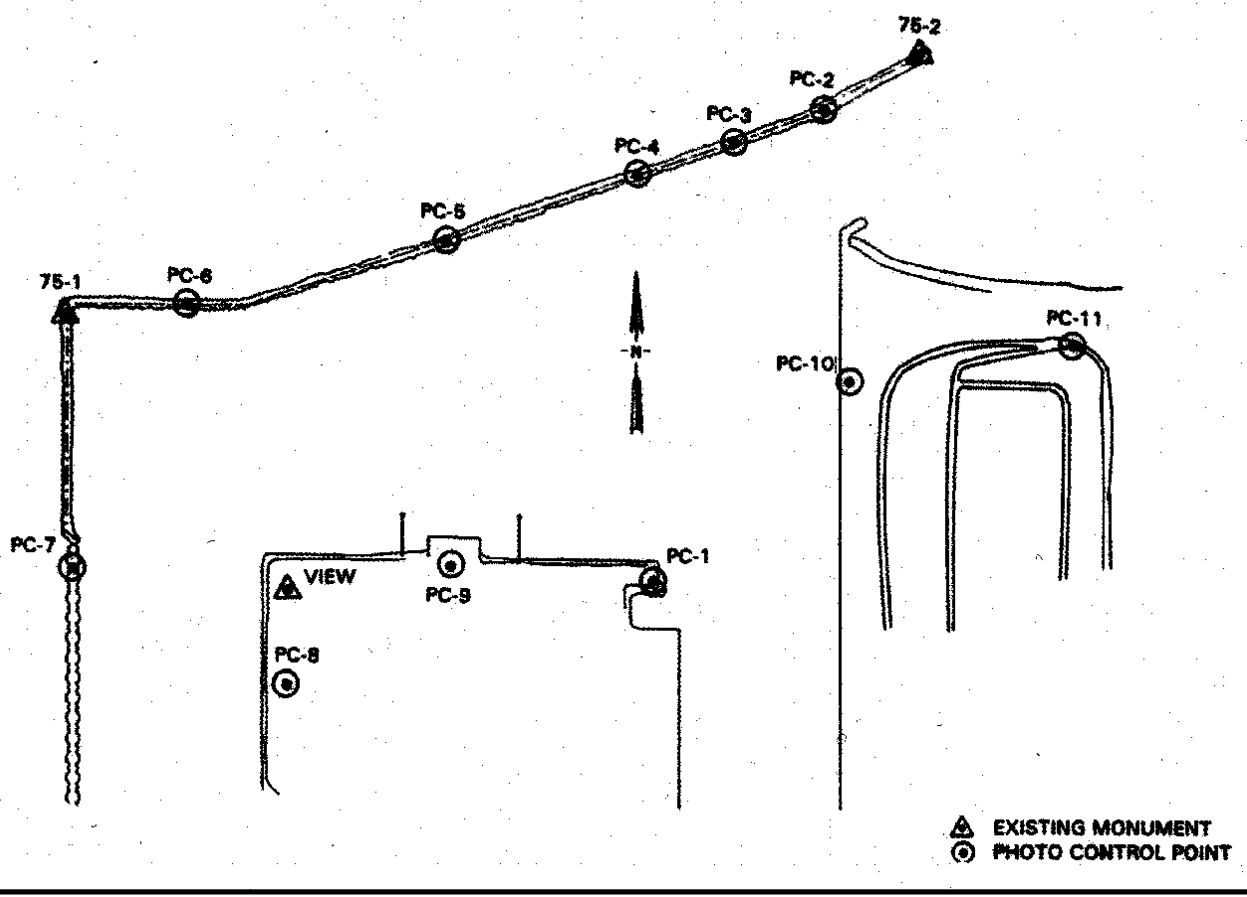

A total of 225 broken armor units were documented during the 1999 survey [Figure 23] versus 165 during the previous survey. Data indicated the majority of additional stone breakage occurred on the harbor side of the structure as opposed to the lakeside. As in the previous survey, higher concentrations of broken stone were noted on the eastern one-third of the breakwater during the current monitoring effort.

To reduce wave heights at the breakwater and minimize further damage, a submerged reef breakwater had been constructed lakeward of the original structure during the construction seasons between J une 1995 and August 1998. The photogrammetry conducted in 1999 not only quantified changes since 1995 but established new base conditions for the structure upon which the performance of the reef breakwater can be evaluated in future years. 
Figure 23. Distribution of broken armor stones on Burns Harbor North Breakwater, August 1999 walking inspection (after Bottin and Tibbetts 2000).

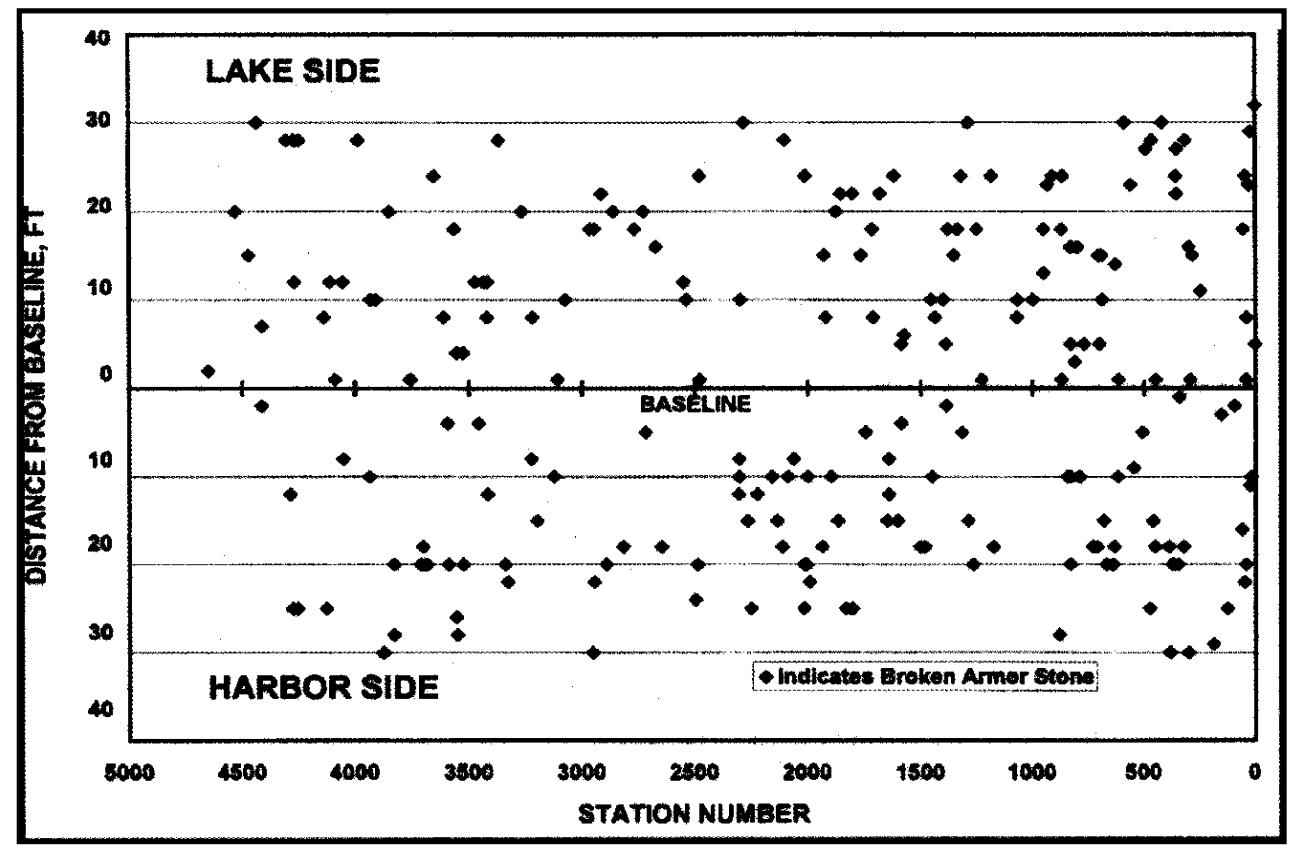

\subsection{Burns Harbor North Breakwater 2004 Periodic Inspections walking inspection}

In April 2004, a walking inspection of the Burns Harbor North Breakwater was conducted. Numerous repairs to the structure had been completed since the 1999 inspection to flatten slopes and raise the crest elevation to design levels, with more work scheduled for 2004 and 2005. Comparison views of the breakwater are shown in Figures 24 and 25. Results and suggestions are summarized by Bottin et al. (2004) as follows:

Inspection of the Burns Harbor North Breakwater in 2004 revealed that the structure's cross section was significantly improved compared to the previous inspection in 1999. Several steep areas were noted during the inspection on the seaside and harbor-sides of the breakwater, as well as an area of crest subsidence. However, most deficiencies were in reaches that were not recently repaired. Overall, the breakwater was in good condition, and recently repaired portions were in excellent condition. The structure should be inspected periodically, particularly after major storm events. After repairs are completed in 2005, consideration should be given to monitoring the structure through photogrammetry to establish new base conditions upon which to evaluate the performance of the rehabilitated breakwater. 
Figure 24. Burns Harbor North Breakwater, August 1999 walking inspection, looking east.

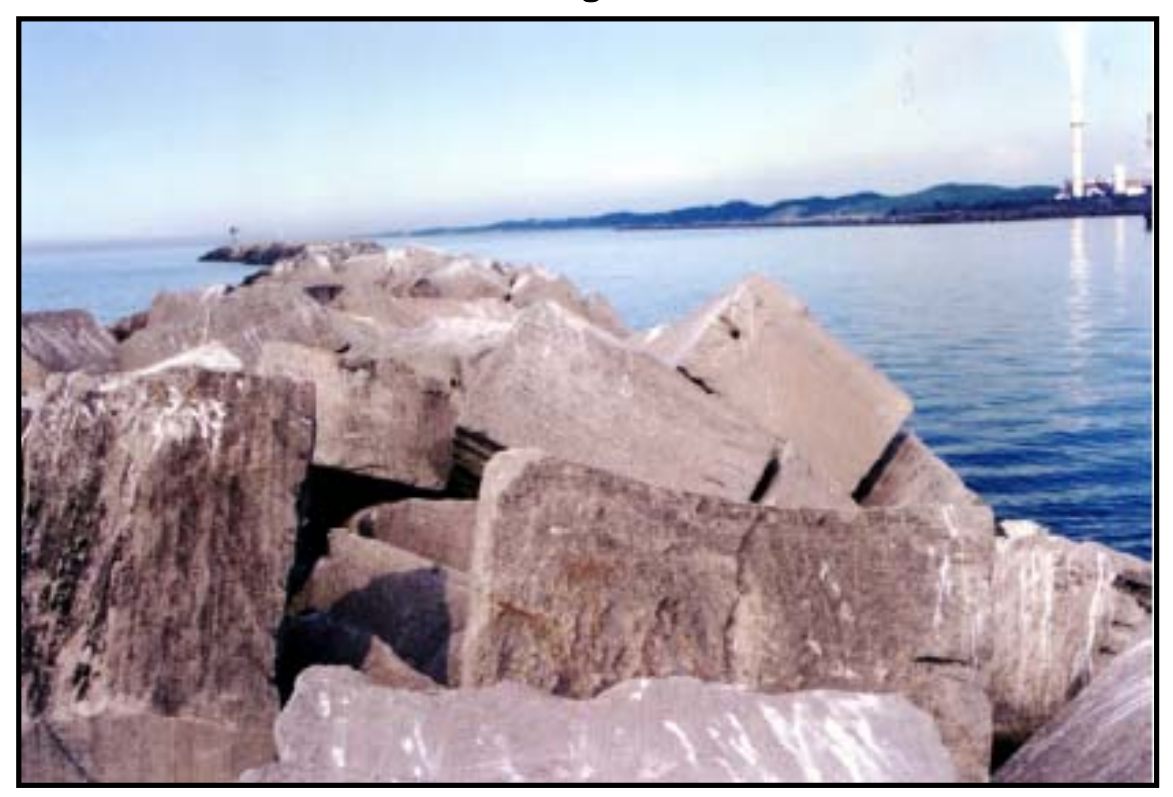

Figure 25. Burns Harbor North Breakwater, April 2004 walking inspection after repairs, looking east.

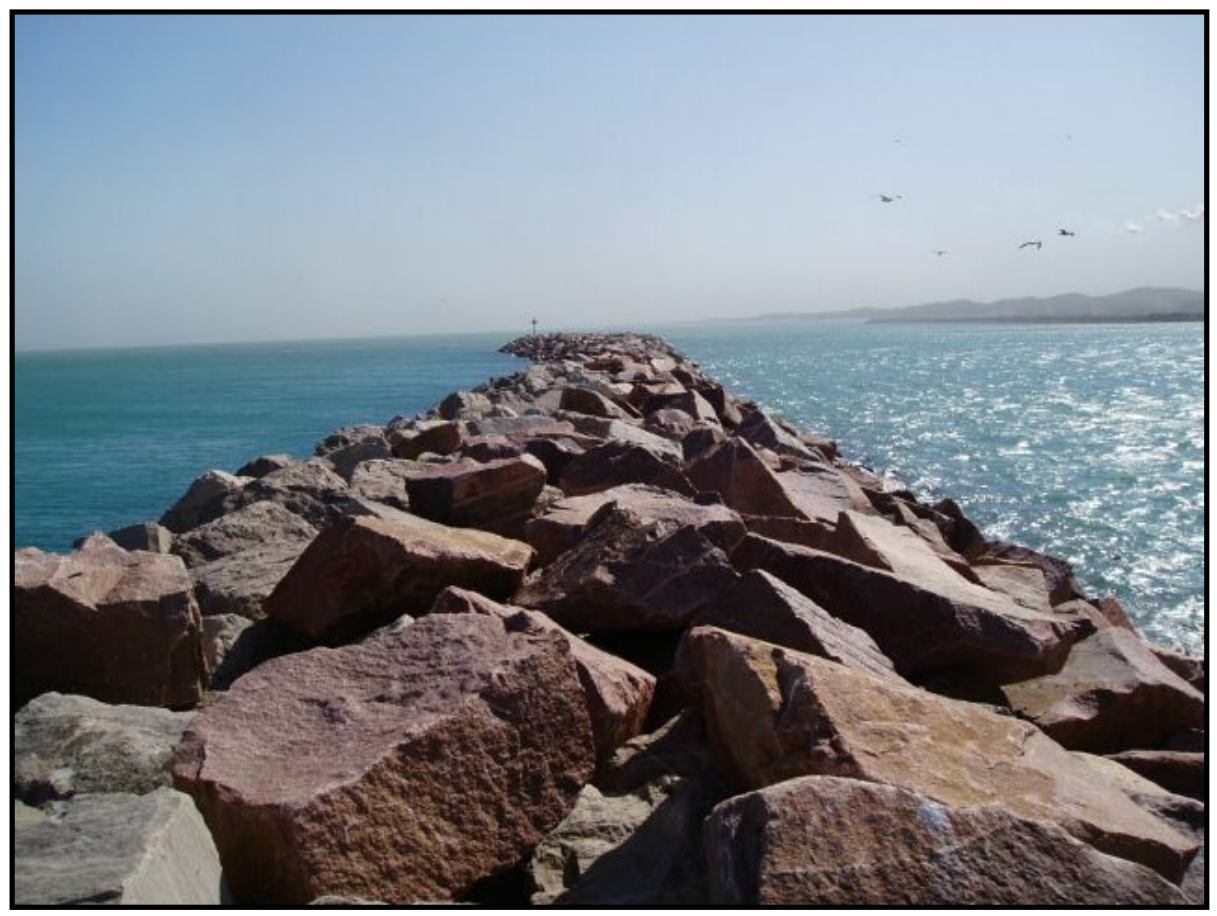




\section{Periodic Inspections Monitoring Plan and Walking Inspections}

The objective of the 2006 Periodic Inspections monitoring was to revisit previously monitored sites to determine and define changes in those breakwaters. To accomplish this, sites were prioritized by HQUSACE and ERDC, with Cleveland Harbor East Breakwater and Burns Harbor North Breakwater being selected as two sites with the most critical need for reevaluation monitoring.

Reasons for the selections included the following:

1. Extensive rehabilitations and repairs to the Burns Harbor North Breakwater dictated a need to establish new baseline data to better understand the effectiveness of the submerged reef system.

2. A detailed monitoring of the Cleveland Harbor East Breakwater had not been conducted in $13 \mathrm{yr}$, longer than any previously monitored location within the Periodic Inspections work unit.

3. The close proximity of the two sites allowed for work to be conducted concurrently, contributing to significant cost savings.

4. JALBTCX was scheduled to conduct lidar topographic survey flights on both Cleveland Harbor and Burns Harbor in the summer of 2006.

A new approach, when compared to past monitoring efforts, was implemented by incorporating some of the older proven methods with newer ideas. For these surveys, aerial photography and photogrammetry were not used. Funding limitations and a significant increase in costs of contracting aerial photography and photogrammetry services mandated the need for adaptation of more cost-effective surveying technology.

The 2006 monitoring plan consisted of limited ground-truth surveys, broken armor unit surveys, and utilization of lidar flights. In addition to monitoring both Cleveland Harbor and Burns Harbor breakwaters, a significant strategic investment was put into the development of a Geographic Information System (GIS) specific to Periodic Inspections work unit sites. 


\subsection{Ground-truth surveys}

Ground-truth surveys are used to establish base conditions for a breakwater's armor units and serve as controls for future comparisons. Typically, monuments as described in Chapter 2 are cemented onto permanent structures or areas not likely to be disturbed so that they may be referenced in the future with a high degree of accuracy. Usually these monuments are located on the land and/ or on the cap of the breakwater (e.g., lighthouse bases) and used for horizontal and vertical references with respect to national datums. In addition to typical land survey methods, GPS coordinates are recorded for each monument and/ or control point location. Other control points are located along the breakwater for use in determining armor movement and/ or subsidence. Control points are usually located on large stable armor in the form of a monument, but occasionally something as simple as a nail embedded into the armor or a marked drill hole is used.

Another use for the ground-truth surveys has been to rectify photogrammetry (not used in the 2006 walking inspections). For this Periodic Inspection, previous surveys were used (a) for direct comparisons to current monitoring efforts, (b) to establish new control points at Burns Harbor, and (c) to validate the lidar elevation data.

\subsection{Detailed walking inspections}

Detailed walking inspections provide a relatively low-cost, expedient analysis of the performance of breakwater armor in its environment relative to past monitoring. Walking inspections also reveal details often unavailable through aerial photography or lidar, such as undermining and/ or deterioration of the underlayer. Also, broken armor unit walking inspections are significantly more accurate than aerial or boat surveys.

During J uly 2006, a detailed walking inspection of the eastern 4,400 ft dolosse section of Cleveland Harbor East Breakwater was conducted. The stone armor section was not included during this particular inspection.

During August 2006, a detailed walking inspection of the Burns Harbor North Breakwater was conducted. (The Burns Harbor East Breakwater was also inspected at this time, but since this breakwater has not previously been a part of the Periodic Inspections work unit, those data are not included as part of this report). 
Voids, depressions, undermining, and steep slopes were recorded. Significantly damaged armor units and stones were the primary focus of this effort. For armor units or stones to be considered significantly damaged, they had to be cracked throughout or broken. Each broken armor stone was recorded to include the approximate station number location, distance from the breakwater center line, and GPS coordinates. Photographs were taken of each, and a database established at CHL. Hairline fractures and spalling were often noted but were not recorded by this monitoring effort.

\subsection{Light detection and ranging (lidar)}

The JALBTCX performs operations, research, and development in airborne lidar bathymetry and topographic surveys, and complementary technologies for the purpose of coastal mapping and charting. The National Coastal Mapping Program (NCMP) supports the USACE requirement for regional management of coastal projects by collecting recurrent surveys along the sandy-shorelines. The NCMP collects high resolution lidar bathymetry and topography, hyperspectral imagery, and aerial photographs using the Coastal Zone Mapping and Imaging Lidar (CZMIL) system (Tuell et al. 2010; Reif et al. 2013; Wozencraft 2013). The CZMIL is the third generation integrated airborne sensor suite that represents the latest technology for improved coastal mapping and includes a lidar sensor, hyperspectral imager, and aerial digital camera system.

The lidar sensor uses a blue-green laser for improved water penetration and is a waveform-resolving system with a segmented detector array resulting in seven waveforms on land and water. The short laser pulselength, high laser power, and a circular scan pattern result in improved coastal mapping in shallow, turbid waters. In addition, the circular scan pattern generates a forward and backward measurement in water that increases breaking wave penetration and water column property detection. Vertical accuracy on land and water is 9.25 centimeters $(\mathrm{cm})$ root mean square error (RMSE) and $15 \mathrm{~cm}$ RMSE, respectively. Nominal point spacing (NPS) is 0.7 meters $(\mathrm{m})$ on land and shallow water and is $2 \mathrm{~m}$ in optically deep water (Tuell et al. 2010; Wozencraft 2013).

A Compact Airborne Spectrographic Imager (CASI)-1500 hyperspectral imager is included on the sensor suite and can collect up to 288 spectral bands at 1.9 nanometer intervals resulting in 1 to $2 \mathrm{~m}$ spatial resolution. The hyperspectral imagery supports feature detection and classification. In 
addition, the CZMIL includes an aerial digital camera system (CS-4800) for acquisition of high spatial resolution imagery $(5 \mathrm{~cm})$.

For the purpose of this periodic inspections work, the J ALBTCX systems collected both topography and surrounding underwater bathymetry. Figure 26 shows an example of a color fill plot of lidar data. The data in this figure are from Burns Harbor North Breakwater.

Figure 26. Lidar data from Burns Harbor North Breakwater, Portage, IN.

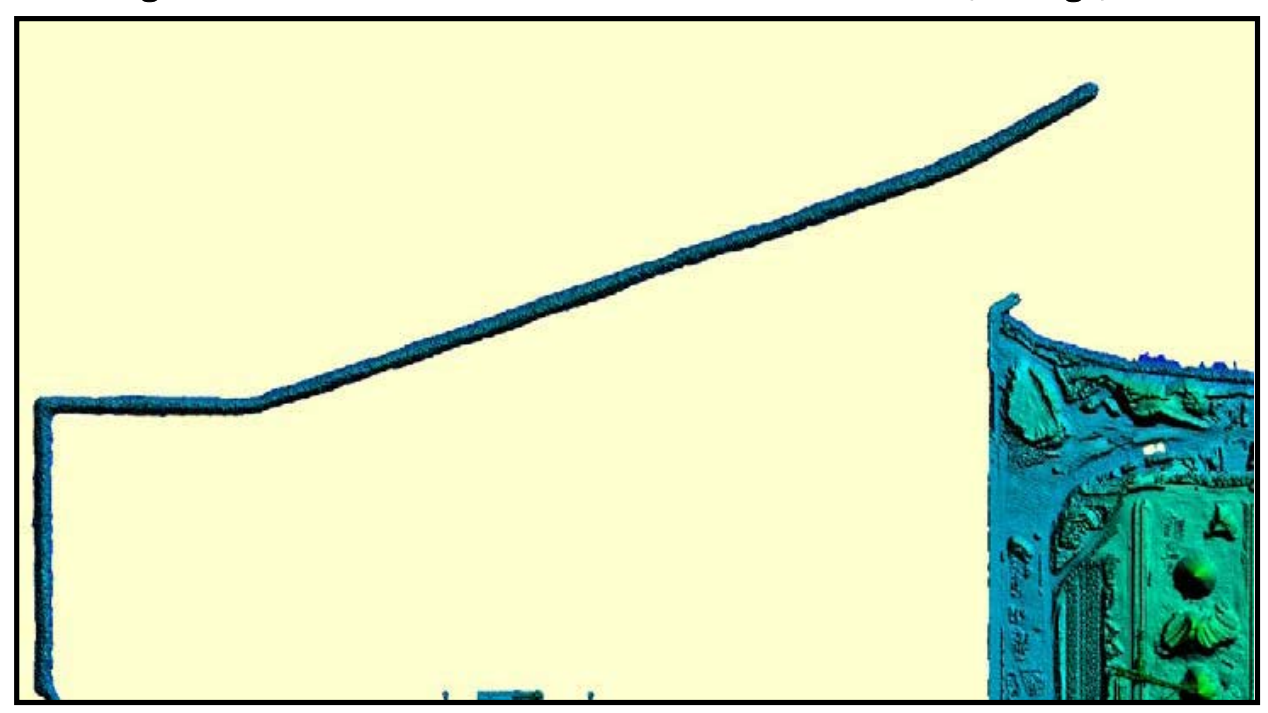

\subsection{Periodic Inspections walking inspections}

\subsubsection{Cleveland Harbor East Breakwater broken dolos walking inspection}

During the detailed walking inspection of J uly 2006, 1,128 broken/ cracked dolos armor units were identified above the waterline. Water levels during the walking inspection fluctuated very little with extremes of 571.5 to $571.8 \mathrm{ft} \mathrm{IGLD85}$ and with an average of $571.7 \mathrm{ft}$ IGLD85 (Figure 27). Water level data were obtained from NOAA wave gage number 9063063 located offshore of Cleveland, $\mathrm{OH}$, at latitude $41^{0} 32.4^{\prime} \mathrm{N}$ and longitude 81038.1' W.

Locations of damaged dolosse were referenced to station numbers beginning at the breakwater head and to the breakwater center line, except in cases where the dolosse were on the water's edge. GPS coordinates were associated with each dolos. 
Figure 27. Water level $(\mathrm{m})$ time history from NOAA offshore gauge 9063063 , Cleveland Harbor East Breakwater, July 2006 detailed walking inspection.

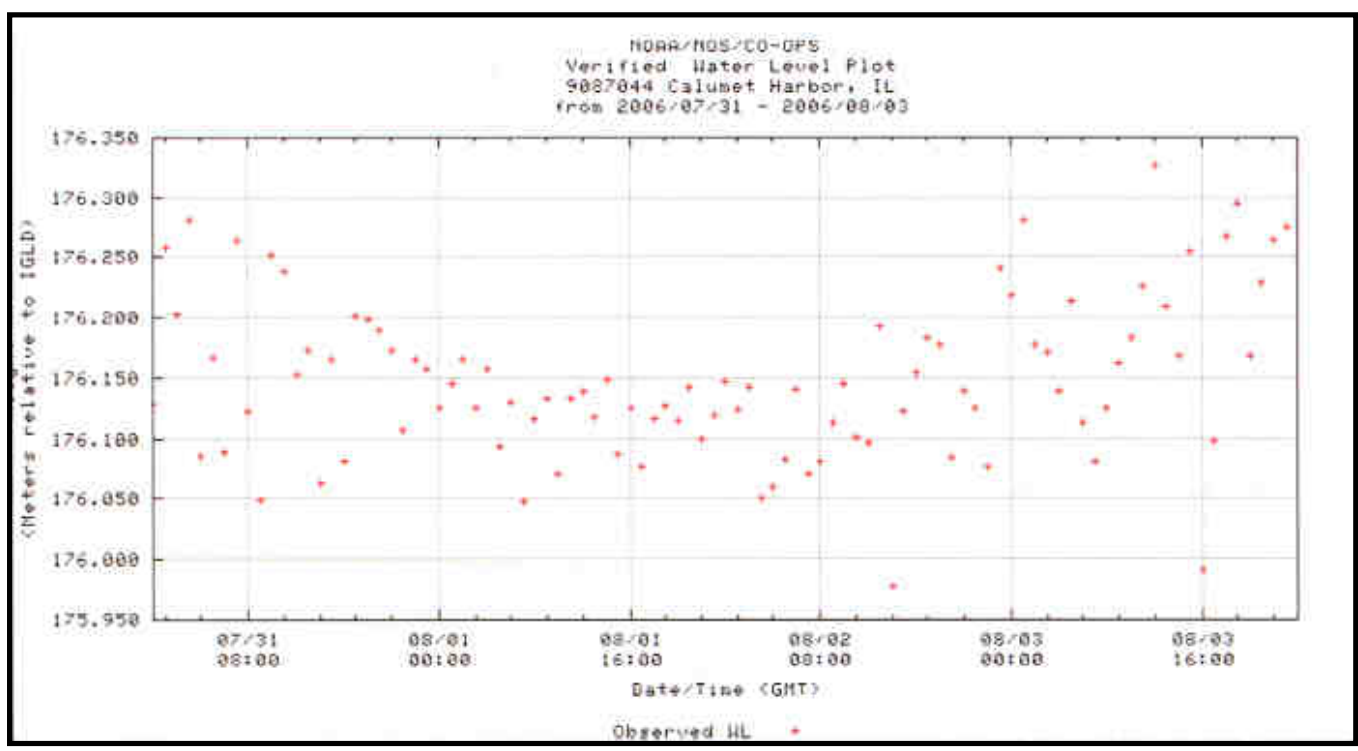

Of the 1,128 broken/ cracked dolosse, 32 were from around the head with the remaining 1,096 along the trunk of the East Breakwater dolos section, and almost all were on the lake side. A distribution chart can be seen in Figure 28. Station numbers were measured with a tape for accuracy, often relying on older station marks for validation.

Figure 28. Distribution of damaged dolos armor units along Cleveland Harbor East Breakwater relative to station number, July 2006 detailed walking inspection.

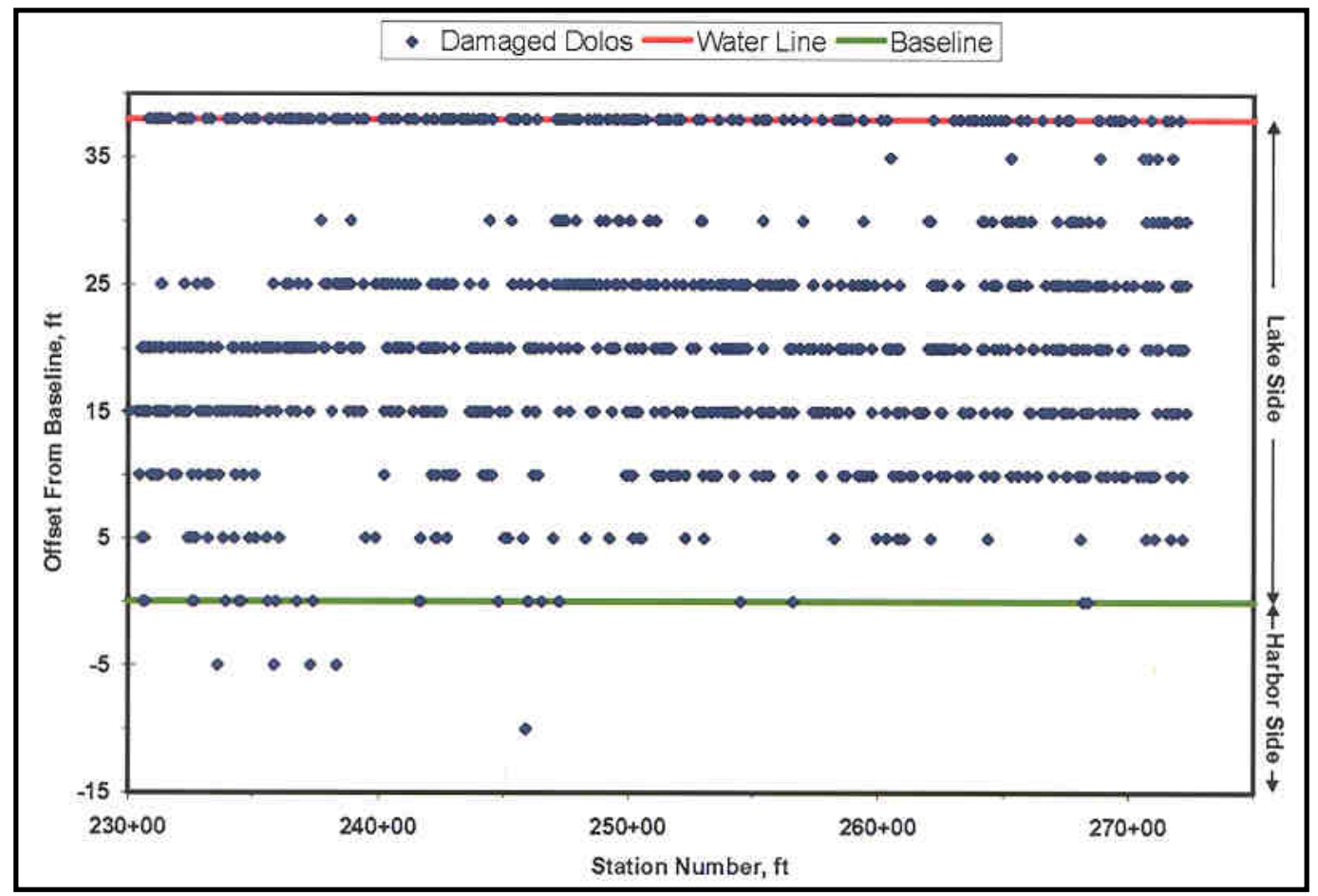


Figure 29 shows an aerial photograph and layout example of station marks on the Cleveland Harbor East Breakwater. Dolos distances from the center line were estimated on $5 \mathrm{ft}$ intervals. A handheld Garmin GPS unit was used to take latitude, longitude, and elevation coordinates for each damaged dolos. This provided approximate location measurements and was used to determine the efficacy of this process for future monitoring as well as to provide a baseline for the Periodic Inspections GIS.

Figure 29. Example of station number layout for Cleveland Harbor East Breakwater.

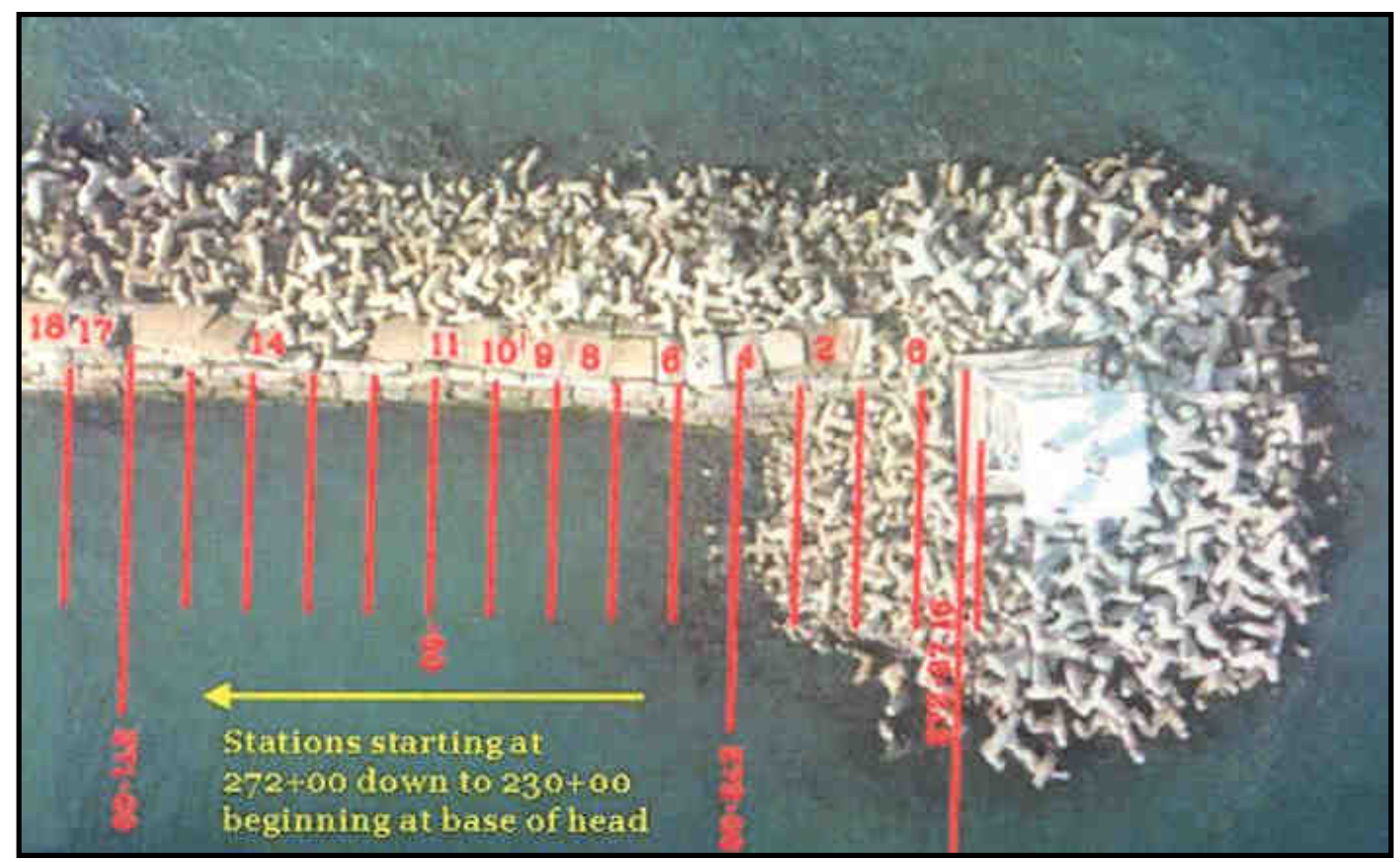

Of the 1,128 damaged dolos units, 171 were found to have multiple breaks/ cracks. Thirty-two of the 171 were in pieces. This is significant for comparison purposes because the 1993 monitoring did not count dolosse broken into pieces. The number of comparable multiple breaks for 2006 is 139 versus 48 in 1993, and the overall number of damaged dolosse is 1,096 for the 2006 walking inspection versus 782 in 1993. These data are shown in Figure 30 for the intervening 13 yr between 1993 and 2006.

With 692 broken/ cracked dolosse in 1985, 782 in 1993, and 1,096 comparable dolosse in 2006, it appears the rate of breakage has somewhat increased. The 8 yr difference between 1985 and 1993 yielded an average of 11.25 new broken units per year, while the $13 \mathrm{yr}$ difference between 1993 and 2006 showed an average of 24.1 new broken units per year, more than double. 
Figure 30. Cumulative number of broken dolos armor units, including July 2006 detailed walking inspection, Cleveland Harbor East Breakwater.

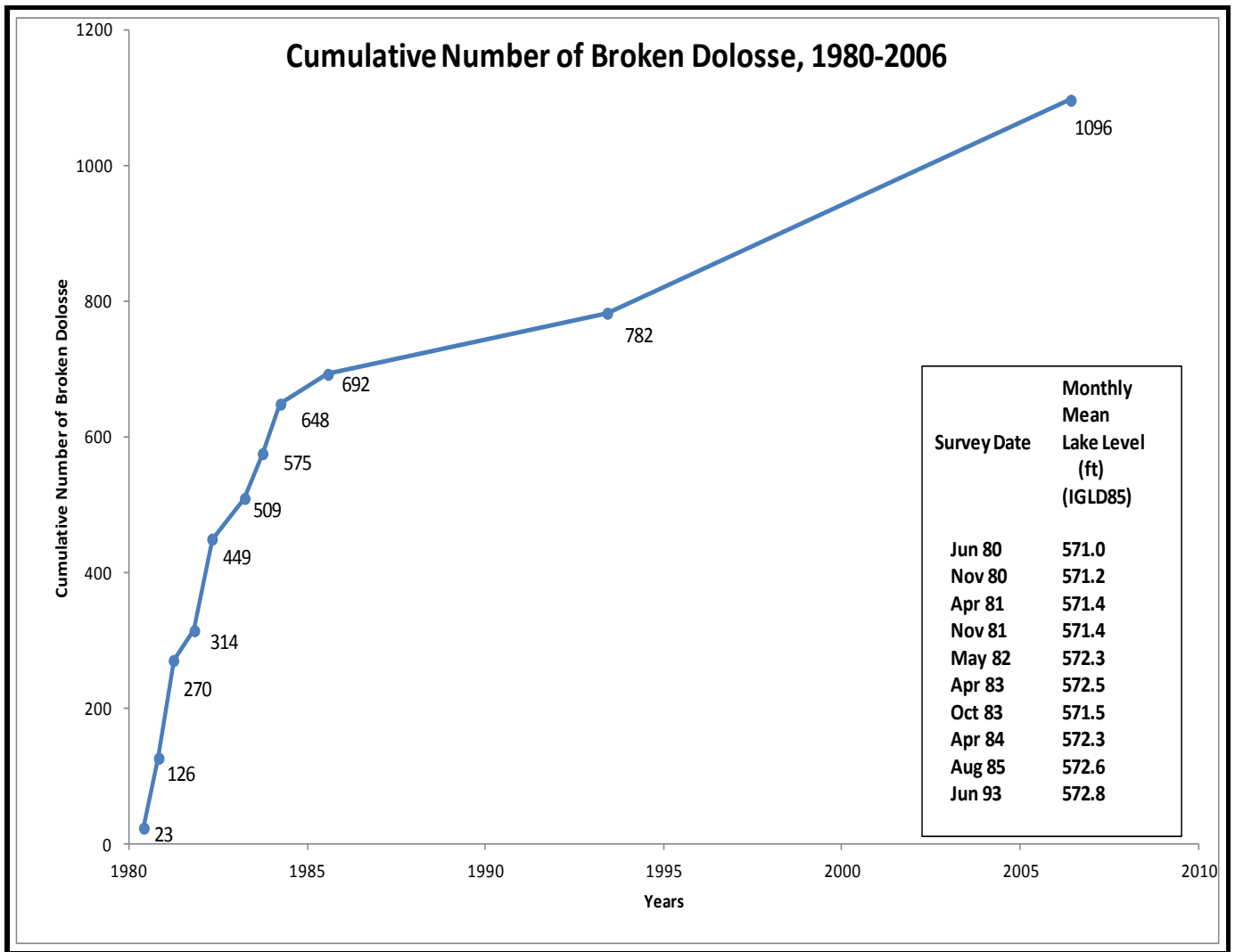

The types of breaks are categorized into 13 detailed groups, more than previous studies. The damage groups include

1. straight shank

2. strait mid-shank

3. angled shank

4. angled mid-shank

5. cracked shank

6. straight fluke

7. straight fluke tip

8. angled fluke

9. angled fluke tip

10. cracked fluke

11. damaged fluke

12. damaged/ broken fluketip

13. pieces. 
A vast majority of breaks occurred along the dolos shank. The total number of shank breaks, including multiple breaks, was 1,873. Fluke breaks only accounted for 470 of the total. Pieces accounted for the other 31 breaks, but they were counted as whole unit breaks, not multiple.

A complete list of broken/ damaged dolosse, and their locations relative to GPS coordinates, station number, and estimated distance from the breakwater center line, can be seen in Appendix A.

\subsubsection{Burns Harbor North Breakwater broken stone walking inspection}

The detailed walking inspection of Burns Harbor North Breakwater revealed 282 broken/ cracked armor stones. Water levels during the walking inspection fluctuated very little with extremes of 577.4 to $578.4 \mathrm{ft}$ IGLD85 and with an average of $577.9 \mathrm{ft}$ IGLD85 (Figure 31). Water level data were obtained from NOAA wave gage number 9087044 located offshore of Calumet Harbor, IL, at latitude 41048.8' N and longitude 87o32.3’ W.

Figure 31. Water level (m) time-history from NOAA offshore gauge 9087044, Burns Harbor North Breakwater, August 2006 detailed walking inspection.

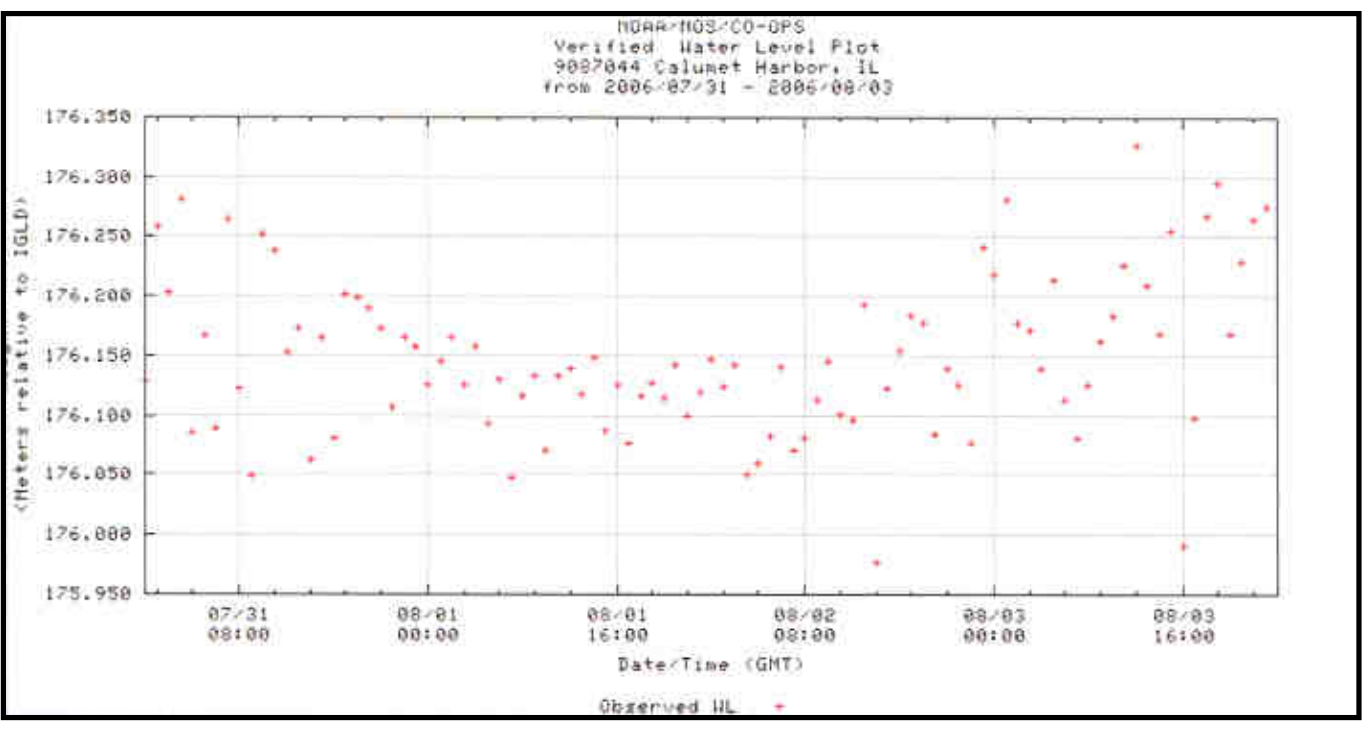

There were five types of stone identified during the walking inspection that had sustained damage:

1. granite

2. dolomite

3. quartzite 
4. Indiana Bedford limestone

5. smaller blocks of limestone that could not beverified as Bedford limestone.

Of the 282 damaged armor stones noted, 46 (16\%) were granite, 84 (\%) were dolomite, 2 (1\%) were quartzite, 136 (48\%) were Indiana Bedford limestone, and 14 (5\%) were the unidentifiable limestone. Twenty-two of the damage locations were situated along the crest of the breakwater, 150 on the lake side of the structure and 110 on the harbor side of the structure. A distribution of the damage location referred to the centerline can be seen in Figure 32. Figure 33 shows the locations of the damaged stones recorded with the handheld GPS unit overlain on NOAA Nautical Chart 14905_4. Figure 34 is a photograph of the breakwater looking east that was taken during the walking inspection. A complete list of the damaged armor stones, with GPS locations and station numbers, can be found in the Appendix B.

Of the 282 damaged stones, 195 were found to have split completely through, and 17 were noted as pieces, where stones had eroded and been damaged to the point that no substantial pieces of stone were left. During the 1999 walking inspection, 225 broken stones had been documented over the same reach.

Figure 32. Distribution of damaged stone armor units along Burns Harbor North Breakwater relative to station number, August 2006 detailed walking inspection.

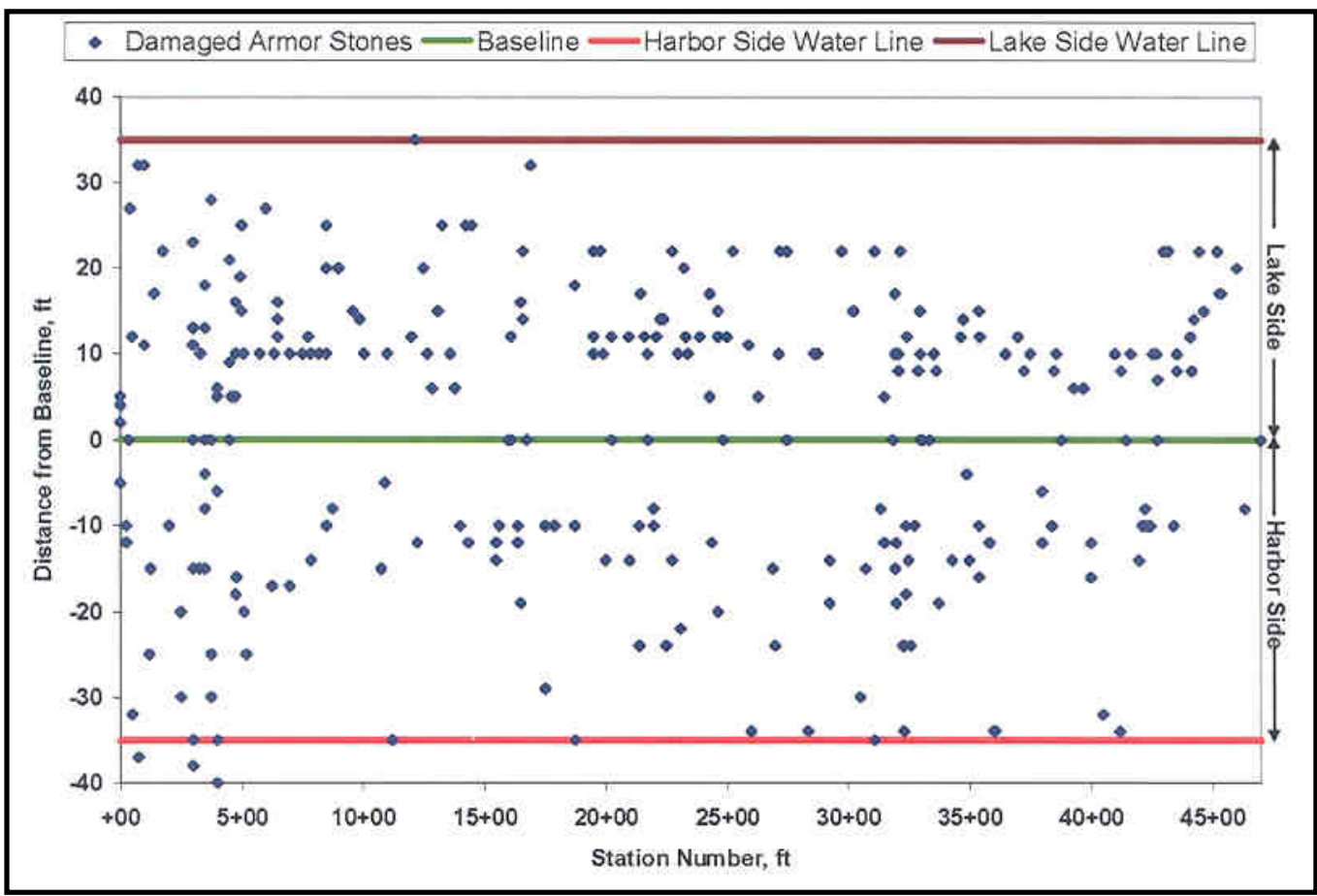


Figure 33. Locations of broken armor stones along Burns Harbor North Breakwater, August 2006 detailed walking inspection.

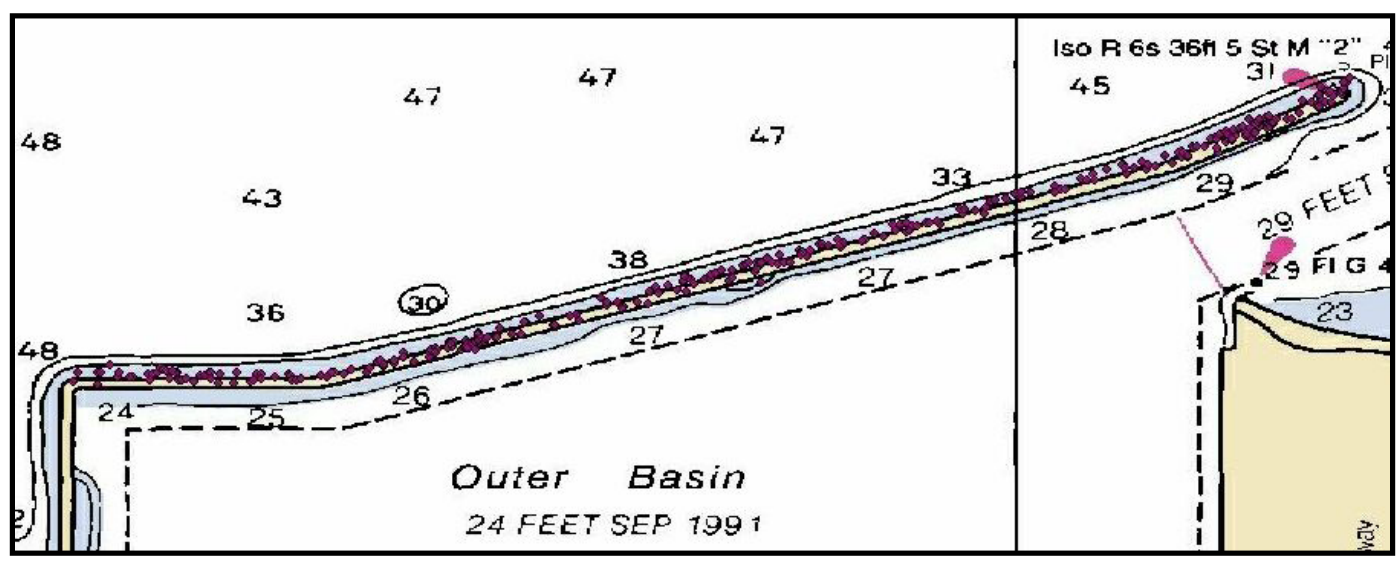

Figure 34. Burns Harbor North Breakwater looking east, August 2006 detailed walking inspection. 


\section{Summary and Conclusions}

The MCNP Program was established to evaluate structural and functional performance of existing navigation structures. Under the Periodic Inspections work unit (a part of MCNP), aerial photography, ground-truth surveys, walking inspections, photogrammetry, and lidar are used to assess the structural conditions of select structures. A database of the existing data on all Periodic Inspections structures has been compiled to centralize data.

Cleveland Harbor East Breakwater, $\mathrm{OH}$, has sustained extensive damage since its original construction was completed in 1915. The East Breakwater has had an extensive repair and rehabilitation history, including a major rehabilitation in 1979- 80 that involved the placement of 2-ton dolosse on the lakeward slope and damaged crest of the easterly 4,400 ft. Some of these failed and were later replaced with 4-ton dolosse. Other recent repairs to the East Breakwater took place in 1986, 1989, 1991, and 2001 on the nondolos sections.

Burns Harbor North Breakwater, IN, is a 4,640 ft rubble-mound structure with an east-west alignment originally constructed in 1969. The North Breakwater has required extensive maintenance during its lifetime, including the addition of 290 kilotons of stone from original construction until 1989. A submerged reef breakwater system was constructed between 1995 and 1998, $75 \mathrm{ft}$ lakeward of the existing North Breakwater for the purpose of reducing wave energy reaching the existing breakwater.

Monitoring of dolosse and armor stone through walking surveys and inspections has provided useful insight concerning the performance of the structures and the need of future rehabilitation efforts. Current monitoring included ground-truth surveys, detailed walking inspections, and the use of lidar technology. Records indicate that 1,128 broken and/ or cracked dolosse, and 282 damaged armor stones, were documented during the 2006 inspection of Cleveland Harbor East Breakwater and Burns Harbor North Breakwater, respectively.

This interim data report contains a precise record of dolos and stone armor damage existing on these structures in J uly 2006. A comprehensive 
analysis and technical report correlating this damage with storm and water level conditions will be published at a later date as subsequent additional field data is obtained at these two Great Lakes breakwaters.

Periodic inspection and monitoring of these structures should continue and will provide insight into the overall performance of each structure as originally designed and constructed. Monitoring will also document the benefits gained from structural maintenance, rehabilitation, and repairs. 


\section{References}

Acuff, H. F., and R. R. Bottin. 1995. Reef breakwater design for Burns Waterway Harbor, IN. Technical Report CERC-95-1. Vicksburg, MS: U.S. Army Engineer Waterways Experiment Station.

Bottin, R. R. 1988. Case histories of Corps breakwater and jetty structures; Report 3, North Central Division. Technical Report REMR-CO-3. Vicksburg, MS: U.S. Army Engineer Research and Development Center.

Bottin, R. R., D. W. Marcus, and M. C. Mohr. 1995. Periodic inspection of Cleveland Harbor East Breakwater, Ohio; Report 1, Base conditions. Technical Report CERC-95-3. Vicksburg, MS: U.S. Army Engineer Waterways Experiment Station.

Bottin, R. R., and E. W. Matthews. 1996. Periodic inspection of Burns Harbor North Breakwater, Indiana; Report 1, Base conditions. Technical Report CERC-96-8. Vicksburg, MS: U.S. Army Engineer Waterways Experiment Station.

Bottin, R. R., and M. K. Tibbetts. 2000. Periodic inspection of Burns Harbor North Breakwater, Indiana: Armor unit monitoring for period 1994- 1999. ERDC/ CHL TR-00-12. Vicksburg, MS: U.S. Army Engineer Research and Development Center.

Bottin, R. R., and L. R. Tolliver. 1999. Inspections of previously monitored coastal structures. Technical Report CHL-99-3. Vicksburg, MS: U.S. Army Engineer Waterways Experiment Station.

Bottin, R. R., L. R. Tolliver, and G. B. Myrick. 2004. Inspections of previously monitored rubble-mound coastal structures. ERDC/ CHL TR-04-11. Vicksburg, MS: U.S. Army Engineer Waterways Experiment Station.

Carver, R. D., and B. J . Wright. 1995. Reef breakwater wave attenuation and stability tests, Burns Waterway Harbor, IN. Technical Report CERC-95-12. Vicksburg, MS: U.S. Army Engineer Waterways Experiment Station.

Hales, L. Z., and D. L. Richey. 2004. Guidance and lessons learned from monitoring completed navigation projects. ERDC/ EL-04-10. Vicksburg, MS: U.S. Army Engineer Research and Development Center.

Irish, J . L. 2000. An introduction to coastal zone mapping with airborne lidar: The SHOALS system. In Proceedings, 21 Corso di Aggiomamento; In Techniche per la Diffesa Dallinquinamento, Cosenza, Italy.

J ackson, R. A. 1967. Stability of proposed breakwater, Burns Waterway Harbor, Indiana; Hydraulic model investigation. Technical Report 2-766. Vicksburg, MS: U.S. Army Engineer Waterways Experiment Station.

Marcus, D. W. 1994. Cracked breakwater stone investigation, Cleveland East Breakwater, Cleveland, Ohio. (unpublished manuscript). Buffalo, NY: U.S. Army Corps of Engineers, Buffalo District. 
Markle, D. G., and W. G. Dubose. 1985. Wave stability tests of dolos and stone rehabilitation designs for the East Breakwater, Cleveland, Ohio. Technical Report CERC-85-10. Vicksburg, MS: U.S. Army Engineer Waterways Experiment Station.

MoGavock, J . H., N. R. Loesing, and E. R. Dye. 1969. Marine construction at Burns Waterways Harbor. In Proceedings, USACE Annual Environmental Meeting. Chicago, IL.

MoGehee, D. D., H. P. Moritz., T. L. Prickett, and J . C. Shirley. 1997. Burns Harbor, IN, monitoring study; Volume I, Overview of approach and results, Technical Report CERC-97-5. Vicksburg, MS: U.S. Army Engineer Waterways Experiment Station.

Melby, J . A., and G. F. Turk. 1994. Concrete armor unit performance in light of recent research results. In Proceedings; Case Histories of the Design, Construction, and Maintenance of Rubble Mound Structures. American Society of Civil Engineers. Reston, VA, 48- 67.

Pope. J ., R. R. Bottin, and D. Rowen. 1993. Monitoring of East Breakwater rehabilitation at Cleveland Harbor, Ohio. Miscellaneous Paper CERC-93-5. Vicksburg, MS: U.S. Army Engineer Waterways Experiment Station.

Reif, M., J. M. Wozencraft, L. M. Dunkin, C. S. Sylvester, and C. L. Macon. 2013. A review of U.S. Army Corps of Engineers airborne coastal mapping in the Great Lakes. J ournal of Great Lakes Research (30):194- 204.

Tuell, G., K. Barbor, and J . M. Wozencraft. 2010. Overview of the coastal zone mapping and imaging lidar (CZMIL); A new multisensory airborne mapping system for the U.S. Army Corps of Engineers. International Society for Optics and Photonics.

Turk, G., and J . A. Melby. 1995. Core-Loc; A major development in concrete armor. The REMR Bulletin (12)1. Vicksburg, MS: U.S. Army Engineer Waterways Experiment Station.

University of Florida (UF). 1964. Hydraulic model study, Burns Waterway Harbor. Report prepared for the State of Indiana. Gainesville, FL: University of Florida, College of Engineering.

U.S. Army Corps of Engineers (USACE). 1997. Monitoring completed navigation projects. Engineering and Design. ER 1110-2-8151. Washington, DC: U.S. Army Corps of Engineers.

—_. 2006. Great Lakes Navigation system five year development plan; Fact sheets. Presentation to Great Lakes Stakeholders Meeting, Cincinnati, OH. Washington, DC: U.S. Army Corps of Engineers.

U.S. Army Engineer District, Chicago. 1994. Burns Waterway Harbor, IN, breakwater major rehabilitation; Design memorandum. Chicago, IL: U.S. Army Corps of Engineers District.

Wozencraft, J . M. 2013. Using lidar to assess storm damage caused by Hurricane Sandy. LiDAR Magazine 3(2):1-4. 
Zilkoski, D. B. 1993. North American vertical datum and international Great Lakes datum; They are now one and the same. Rockville, MD: U.S. National Oceanic and Atmospheric Administration, National Geodetic Survey, Vertical Network Branch. http://www.ngs.noaa.gov/web/about_ngs/history/Zilkoski4.pdf

Zilkoski, D. B., J . H. Richards, and G. M. Young. 1992. Results of the general adjustment of the North American vertical datum of 1988. Special Report. American Congress on Surveying and Mapping; Surveying and Land Information Systems 52(3):133- 149. http://www.ngs.noaa.gov/PUBS_LlB/NAVD88/navd88report.htm 


\section{Appendix A: Broken/Damaged Dolos Armor Units (Type of Breaks and Locations) on the Cleveland Harbor East Breakwater, July 2006 Walking Inspection}




\begin{tabular}{|c|c|c|c|c|c|c|c|c|c|c|c|c|c|c|c|c|c|}
\hline \multirow[t]{2}{*}{$\begin{array}{l}\text { Dolos } \\
\text { Number }\end{array}$} & \multicolumn{13}{|c|}{ Break Type } & \multicolumn{4}{|c|}{ Location } \\
\hline & $\begin{array}{l}\text { Straight } \\
\text { Shank }\end{array}$ & $\begin{array}{l}\text { Straight } \\
\text { Mid } \\
\text { Shank }\end{array}$ & $\begin{array}{l}\text { Angled } \\
\text { Shank }\end{array}$ & $\begin{array}{l}\text { Angled } \\
\text { Mid } \\
\text { Shank }\end{array}$ & $\begin{array}{l}\text { Cracked } \\
\text { Shank }\end{array}$ & $\begin{array}{l}\text { Straight } \\
\text { Fluke }\end{array}$ & $\begin{array}{c}\text { Straight } \\
\text { Fluke } \\
\text { Tip }\end{array}$ & $\begin{array}{l}\text { Angled } \\
\text { Fluke }\end{array}$ & $\begin{array}{c}\text { Angled } \\
\text { Fluke } \\
\text { Tip }\end{array}$ & $\begin{array}{l}\text { Cracked } \\
\text { Fluke }\end{array}$ & $\begin{array}{l}\text { Damaged } \\
\text { Fluke }\end{array}$ & $\begin{array}{c}\text { Damaged/ } \\
\text { Broken } \\
\text { Fluke Tip }\end{array}$ & Pieces & $\begin{array}{l}\text { Station } \\
\text { Number }\end{array}$ & $\begin{array}{c}\text { Distance } \\
\text { from } \\
\text { Baseline }\end{array}$ & $\begin{array}{c}\text { GPS North } \\
\text { (Decimal } \\
\text { degrees) }\end{array}$ & $\begin{array}{l}\text { GPS 38st } \\
\text { (Decimal } \\
\text { degrees) }\end{array}$ \\
\hline 1 & & & & 1 & & & & & & & & & & & & 4132.589 & 8139.081 \\
\hline 2 & & & & 1 & & & & & & & & & & & & 4132.591 & 8139.079 \\
\hline 3 & & & & & & & & & & & & & 1 & & & 4132.586 & 8139.077 \\
\hline 4 & & & & & & & & & & & & & 1 & & & 4132.586 & 8139.078 \\
\hline 5 & & & & & & & & & & & & & 1 & & & 4132.586 & 8139.080 \\
\hline 6 & & & 1 & & & & & & & & & & & & & 4132.591 & 8139.077 \\
\hline 7 & & & & & & & & & & & & 1 & & & & 4132.591 & 8139.076 \\
\hline 8 & & & & & & & & & & & 1 & & & & & 4132.590 & 8139.074 \\
\hline 9 & & & 1 & & & 1 & & & & & 1 & & & & & 4132.589 & 8139.070 \\
\hline 10 & & & & & & & & & & 1 & & & & & & 4132.584 & 8139.070 \\
\hline 11 & & & & & & & & & 1 & & & & & & & 4132.582 & 8139.071 \\
\hline 12 & & & & & & & & & & & & & 1 & & & 4132.580 & 8139.071 \\
\hline 13 & & & & & & 1 & & & & & & & & & & 4132.581 & 8139.072 \\
\hline 14 & & & & & & 1 & & & & & & & & & & 4132.583 & 8139.072 \\
\hline 15 & & & 1 & & & & & & & & & & & & & 4132.578 & 8139.076 \\
\hline 16 & & & & & & & & 1 & & & & & & & & 4132.578 & 8139.076 \\
\hline 17 & & & & & & & & 1 & & & & & & & & 4132.579 & 8139.079 \\
\hline 18 & 1 & & & & & & & & & & & & & & & 4132.578 & 8139.079 \\
\hline 19 & & & & & & & & 1 & & & & & & & & 4132.579 & 8139.079 \\
\hline 20 & & & 1 & & & 1 & & & & & & & & & & 4132.583 & 8139.079 \\
\hline 21 & & & & & & & & & & & & & 1 & & & & \\
\hline 22 & & & & & & & & & & & & & 1 & & & 4132.582 & 8139.080 \\
\hline 23 & & & 1 & & & & & 1 & & & & & & & & 4132.586 & 8139.082 \\
\hline
\end{tabular}




\begin{tabular}{|c|c|c|c|c|c|c|c|c|c|c|c|c|c|c|c|c|c|}
\hline \multirow[t]{2}{*}{$\begin{array}{l}\text { Dolos } \\
\text { Number }\end{array}$} & \multicolumn{13}{|c|}{ Break Type } & \multicolumn{4}{|c|}{ Location } \\
\hline & $\begin{array}{l}\text { Straight } \\
\text { Shank }\end{array}$ & $\begin{array}{l}\text { Straight } \\
\text { Mid } \\
\text { Shank }\end{array}$ & $\begin{array}{l}\text { Angled } \\
\text { Shank }\end{array}$ & $\begin{array}{c}\text { Angled } \\
\text { Mid } \\
\text { Shank }\end{array}$ & $\begin{array}{l}\text { Cracked } \\
\text { Shank }\end{array}$ & $\begin{array}{l}\text { Straight } \\
\text { Fluke }\end{array}$ & $\begin{array}{c}\text { Straight } \\
\text { Fluke } \\
\text { Tip }\end{array}$ & $\begin{array}{l}\text { Angled } \\
\text { Fluke }\end{array}$ & $\begin{array}{c}\text { Angled } \\
\text { Fluke } \\
\text { Tip }\end{array}$ & $\begin{array}{l}\text { Cracked } \\
\text { Fluke }\end{array}$ & $\begin{array}{l}\text { Damaged } \\
\text { Fluke }\end{array}$ & $\begin{array}{l}\text { Damaged/ } \\
\text { Broken } \\
\text { Fluke Tip }\end{array}$ & Pieces & $\begin{array}{l}\text { Station } \\
\text { Number }\end{array}$ & $\begin{array}{c}\text { Distance } \\
\text { from } \\
\text { Baseline }\end{array}$ & $\begin{array}{l}\text { GPS North } \\
\text { (Decimal } \\
\text { degrees) }\end{array}$ & $\begin{array}{l}\text { GPS 38st } \\
\text { (Decimal } \\
\text { degrees) }\end{array}$ \\
\hline 24 & & & 1 & & & & & & & & & & & & & 4132.584 & 8139.080 \\
\hline 25 & & & & & & & & & & & & & 1 & & & 4132.585 & 8139.079 \\
\hline 26 & & & 1 & & & & & & & & & & & & & 4132.586 & 8139.079 \\
\hline 27 & 1 & & & & & & & & & & & & & & & 4132.587 & 8139.081 \\
\hline 28 & & & & & & 1 & & & & & & & & & & 4132.586 & 8139.083 \\
\hline 29 & & & 1 & & & 1 & & & & & & & & & & 4132.587 & 8139.083 \\
\hline 30 & & & & & & & & 2 & & & & & & & & 4132.582 & 8139.071 \\
\hline 31 & & & & & & 1 & & & & & & & & & & 4132.580 & 8139.070 \\
\hline 32 & & & & & & & & 2 & & & & & & $272+30$ & 30 & 4132.587 & 8139.083 \\
\hline 33 & & & 1 & & & & & & & & & & & & & 4132.579 & 8139.072 \\
\hline 34 & & & 1 & & & & & & & & & & & $272+30$ & 25 & 4132.586 & 8139.085 \\
\hline 35 & & & 1 & & & & & & & & & & & $272+30$ & 15 & 4132.585 & 8139.083 \\
\hline 36 & & & 1 & & & & & & & & & & & $272+15$ & 5 & & \\
\hline 37 & & & & & & 1 & & & & & & & & $272+15$ & 10 & 4132.585 & 8139.086 \\
\hline 38 & & & & & & 1 & & 1 & & & & & & $272+10$ & 25 & 4132.584 & 8139.084 \\
\hline 39 & 1 & & & & & & & & & & & & & $272+05$ & 25 & 4132.586 & 8139.086 \\
\hline 40 & 1 & & & & & & & & & & & & & $272+00$ & 30 & 4132.585 & 8139.087 \\
\hline 41 & 1 & & & & & & & & & & & & & $272+05$ & 38 & 4132.585 & 8139.087 \\
\hline 42 & & & & & & & & 2 & & & & & & $272+05$ & 20 & 4132.586 & 8139.086 \\
\hline 43 & & & & & & & & 1 & & & & & & $272+05$ & 30 & 4132.586 & 8139.088 \\
\hline 44 & & & & & & & & 1 & & & & & & $272+05$ & 38 & 4132.586 & 8139.088 \\
\hline 45 & & & & & & 1 & & & & & & & & $272+00$ & 20 & & \\
\hline 46 & 1 & & & & & & & 1 & & & & & & $272+20$ & 20 & 4132.585 & 8139.087 \\
\hline
\end{tabular}




\begin{tabular}{|c|c|c|c|c|c|c|c|c|c|c|c|c|c|c|c|c|c|}
\hline \multirow[t]{2}{*}{$\begin{array}{l}\text { Dolos } \\
\text { Number }\end{array}$} & \multicolumn{13}{|c|}{ Break Type } & \multicolumn{4}{|c|}{ Location } \\
\hline & $\begin{array}{l}\text { Straight } \\
\text { Shank }\end{array}$ & $\begin{array}{c}\text { Straight } \\
\text { Mid } \\
\text { Shank }\end{array}$ & $\begin{array}{l}\text { Angled } \\
\text { Shank }\end{array}$ & $\begin{array}{l}\text { Angled } \\
\text { Mid } \\
\text { Shank }\end{array}$ & $\begin{array}{l}\text { Cracked } \\
\text { Shank }\end{array}$ & $\begin{array}{l}\text { Straight } \\
\text { Fluke }\end{array}$ & $\begin{array}{c}\text { Straight } \\
\text { Fluke } \\
\text { Tip }\end{array}$ & $\begin{array}{l}\text { Angled } \\
\text { Fluke }\end{array}$ & $\begin{array}{c}\text { Angled } \\
\text { Fluke } \\
\text { Tip }\end{array}$ & $\begin{array}{l}\text { Cracked } \\
\text { Fluke }\end{array}$ & $\begin{array}{l}\text { Damaged } \\
\text { Fluke }\end{array}$ & $\begin{array}{c}\text { Damaged/ } \\
\text { Broken } \\
\text { Fluke Tip }\end{array}$ & Pieces & $\begin{array}{l}\text { Station } \\
\text { Number }\end{array}$ & $\begin{array}{c}\text { Distance } \\
\text { from } \\
\text { Baseline }\end{array}$ & $\begin{array}{c}\text { GPS North } \\
\text { (Decimal } \\
\text { degrees) }\end{array}$ & $\begin{array}{l}\text { GPS 38st } \\
\text { (Decimal } \\
\text { degrees) }\end{array}$ \\
\hline 47 & & & 1 & & & & & & & & & & & nd & nd & 4132.582 & 8139.087 \\
\hline 48 & 1 & & & & & & & & & & & & & $271+95$ & 20 & 4132.584 & 8139.087 \\
\hline 49 & 1 & & & & & & & & & & & & & $271+95$ & 15 & 4132.583 & 8139.087 \\
\hline 50 & & & & & & & & 1 & & & & & & $271+90$ & 25 & 4132.583 & 8139.089 \\
\hline 51 & & & & & & & & 1 & & & & & & $271+90$ & 25 & 4132.584 & 8139.090 \\
\hline 52 & & & & & & & & 1 & & & & & & $271+90$ & 30 & 4132.584 & 8139.090 \\
\hline 53 & & & 1 & & & & & & & & & & & $217+80$ & 35 & 4132.583 & 8139.091 \\
\hline 54 & & & 1 & & & & & & & & & & & $217+80$ & 38 & 4132.582 & 8139.090 \\
\hline 55 & & & 1 & & & & & & & & & & & $217+80$ & 35 & 4132.583 & 8139.092 \\
\hline 56 & & & & & & 2 & & & & & & & & $271+75$ & 35 & 4132.583 & 8139.091 \\
\hline 57 & 1 & & & & & & & & & & & & & $271+75$ & 15 & 4132.582 & 8139.090 \\
\hline 58 & & & 1 & & & & & 1 & & & & & & $271+75$ & 10 & 4132.582 & 8139.090 \\
\hline 59 & & & 1 & & & & & & & & & & & $271+70$ & 10 & 4132.581 & 8139.091 \\
\hline $59 \mathrm{~A}$ & & & & & & & & 1 & & & & & & $271+70$ & 38 & & \\
\hline 60 & & & 1 & & & & & & & & & & & $271+70$ & 5 & 4132.580 & 8139.091 \\
\hline 61 & & & & & & & & 1 & & & & & & $271+70$ & 20 & 4132.581 & 8139.093 \\
\hline 62 & & 1 & & & & & & & & & & & & $271+75$ & 20 & 4132.582 & 8139.092 \\
\hline 63 & & & & & & & & & & & & & 1 & $217+80$ & 20 & 4132.582 & 8139.091 \\
\hline 64 & & & & & & & & & & 1 & & & & $271+50$ & 15 & 4132.579 & 8139.092 \\
\hline 65 & & & & & 1 & & & & & & & & & $271+50$ & 15 & 4132.580 & 8139.094 \\
\hline 66 & & & 1 & & & & & & & & & & & $271+50$ & 30 & 4132.581 & 8139.096 \\
\hline 67 & & & 1 & & & & & & & & & & & $271+50$ & 30 & 4132.580 & 8139.097 \\
\hline 68 & & 1 & & & & & & & & & & & & $271+50$ & 38 & 4132.582 & 8139.097 \\
\hline
\end{tabular}




\begin{tabular}{|c|c|c|c|c|c|c|c|c|c|c|c|c|c|c|c|c|c|}
\hline \multirow[t]{2}{*}{$\begin{array}{l}\text { Dolos } \\
\text { Number }\end{array}$} & \multicolumn{13}{|c|}{ Break Type } & \multicolumn{4}{|c|}{ Location } \\
\hline & $\begin{array}{l}\text { Straight } \\
\text { Shank }\end{array}$ & $\begin{array}{c}\text { Straight } \\
\text { Mid } \\
\text { Shank }\end{array}$ & $\begin{array}{l}\text { Angled } \\
\text { Shank }\end{array}$ & $\begin{array}{l}\text { Angled } \\
\text { Mid } \\
\text { Shank }\end{array}$ & $\begin{array}{l}\text { Cracked } \\
\text { Shank }\end{array}$ & $\begin{array}{l}\text { Straight } \\
\text { Fluke }\end{array}$ & $\begin{array}{c}\text { Straight } \\
\text { Fluke } \\
\text { Tip }\end{array}$ & $\begin{array}{l}\text { Angled } \\
\text { Fluke }\end{array}$ & $\begin{array}{c}\text { Angled } \\
\text { Fluke } \\
\text { Tip }\end{array}$ & $\begin{array}{l}\text { Cracked } \\
\text { Fluke }\end{array}$ & $\begin{array}{l}\text { Damaged } \\
\text { Fluke }\end{array}$ & $\begin{array}{c}\text { Damaged/ } \\
\text { Broken } \\
\text { Fluke Tip }\end{array}$ & Pieces & $\begin{array}{l}\text { Station } \\
\text { Number }\end{array}$ & $\begin{array}{c}\text { Distance } \\
\text { from } \\
\text { Baseline }\end{array}$ & $\begin{array}{c}\text { GPS North } \\
\text { (Decimal } \\
\text { degrees) }\end{array}$ & $\begin{array}{l}\text { GPS 38st } \\
\text { (Decimal } \\
\text { degrees) }\end{array}$ \\
\hline 69 & & & 1 & & & & & & & & & & & $271+20$ & 20 & 4132.577 & 8139.098 \\
\hline 70 & & & 1 & & & & & & & & & & & $271+20$ & 20 & 4132.576 & 8139.099 \\
\hline 71 & & & & 1 & & & & & & & & & & $271+20$ & 25 & 4132.579 & 8139.099 \\
\hline 72 & & & & 1 & & & & & & & & & & $271+20$ & 30 & 4132.578 & 8139.098 \\
\hline 73 & 1 & & & & & & & & & & & & & $271+40$ & 30 & 4132.579 & 8139.098 \\
\hline 74 & & & & 1 & & & & & & & & & & $271+20$ & 25 & 4132.576 & 8139.100 \\
\hline 75 & & & 1 & & & & & & & & & & & $271+50$ & 30 & 4132.579 & 8139.098 \\
\hline 76 & & & & & & & & & & & & & 1 & $271+20$ & 30 & 4132.577 & 8139.100 \\
\hline 77 & & & 1 & & & & & & & & & & & $271+15$ & 35 & 4132.578 & 8139.100 \\
\hline 78 & & & & & & & & & & & & & 1 & $271+15$ & 20 & 4132.577 & 8139.100 \\
\hline 79 & & & & & & & & 1 & & & & & & $271+15$ & 15 & 4132.577 & 8139.100 \\
\hline 80 & & & 1 & & & & & & & & & & & $271+05$ & 10 & 4132.577 & 8139.101 \\
\hline 81 & & & 1 & & & 1 & & & & & & & & $271+05$ & 5 & 4132.574 & 8139.102 \\
\hline 82 & & & & & & & & 1 & & & & & & $270+95$ & 30 & 4132.576 & 8139.104 \\
\hline 83 & & & & 1 & & & & & & & & & & $270+95$ & 25 & 4132.574 & 8139.107 \\
\hline 84 & & & & & & 1 & & & & & & & & $270+85$ & 20 & 4132.575 & 8139.106 \\
\hline 85 & & & & & & & & & & 1 & & & & $270+85$ & 10 & 4132.573 & 8139.106 \\
\hline 86 & 1 & & & & & & & & & & & & & $270+85$ & 10 & 4132.574 & 8139.104 \\
\hline 87 & 1 & & & & & & & & & & & & & $270+70$ & 20 & 4132.574 & 8139.108 \\
\hline 88 & & & 1 & & & & & & & & & & & $270+70$ & 25 & 4132.573 & 8139.108 \\
\hline 89 & 1 & & & & & & & & & & & & & $270+70$ & 20 & 4132.572 & 8139.109 \\
\hline 90 & & & & & 1 & & & & & & & & & $270+70$ & 5 & 4132.571 & 8139.108 \\
\hline 91 & & & 1 & & & & & & & & & & & $270+60$ & 10 & 4132.571 & 8139.109 \\
\hline
\end{tabular}




\begin{tabular}{|c|c|c|c|c|c|c|c|c|c|c|c|c|c|c|c|c|c|}
\hline $\begin{array}{l}\text { Dolos } \\
\text { Number }\end{array}$ & \multicolumn{13}{|c|}{ Break Type } & \multicolumn{4}{|c|}{ Location } \\
\hline & $\begin{array}{l}\text { Straight } \\
\text { Shank }\end{array}$ & $\begin{array}{l}\text { Straight } \\
\text { Mid } \\
\text { Shank }\end{array}$ & $\begin{array}{l}\text { Angled } \\
\text { Shank }\end{array}$ & $\begin{array}{l}\text { Angled } \\
\text { Mid } \\
\text { Shank }\end{array}$ & $\begin{array}{l}\text { Cracked } \\
\text { Shank }\end{array}$ & $\begin{array}{l}\text { Straight } \\
\text { Fluke }\end{array}$ & $\begin{array}{l}\text { Straight } \\
\text { Fluke } \\
\text { Tip }\end{array}$ & $\begin{array}{l}\text { Angled } \\
\text { Fluke }\end{array}$ & $\begin{array}{l}\text { Angled } \\
\text { Fluke } \\
\text { Tip }\end{array}$ & $\begin{array}{l}\text { Cracked } \\
\text { Fluke }\end{array}$ & $\begin{array}{l}\text { Damaged } \\
\text { Fluke }\end{array}$ & $\begin{array}{c}\text { Damaged/ } \\
\text { Broken } \\
\text { Fluke Tip }\end{array}$ & Pieces & $\begin{array}{l}\text { Station } \\
\text { Number }\end{array}$ & $\begin{array}{c}\text { Distance } \\
\text { from } \\
\text { Baseline }\end{array}$ & $\begin{array}{c}\text { GPS North } \\
\text { (Decimal } \\
\text { degrees) }\end{array}$ & $\begin{array}{l}\text { GPS 38st } \\
\text { (Decimal } \\
\text { degrees) }\end{array}$ \\
\hline 92 & 1 & & & & 1 & & & & & 1 & & & & $270+95$ & 10 & 4132.573 & 8139.104 \\
\hline 93 & & & & & & & & 2 & & & & & & $270+90$ & 38 & & \\
\hline 94 & & & & & & 1 & & & & & & & & $270+80$ & 35 & 4132.572 & 8139.113 \\
\hline 95 & & & & & & 1 & & & & & & & & $270+70$ & 30 & 4132.572 & 8139.113 \\
\hline 96 & & & & & & & & 1 & & & & & & $270+60$ & 10 & 4132.571 & 8139.112 \\
\hline 97 & & & & & & & & 1 & & & & & & $270+60$ & 35 & 4132.572 & 8139.116 \\
\hline 98 & & & & & & & & & & & & & 1 & $270+40$ & 10 & 4132.570 & 8139.114 \\
\hline 99 & & & & & & 1 & & & & & & & & $270+20$ & 15 & 4132.569 & 8139.117 \\
\hline 100 & & & & 1 & & & & & & & & & & $270+20$ & 25 & 4132.569 & 8139.117 \\
\hline 101 & & & 1 & & & & & & & & & & & $270+20$ & 38 & 4132.569 & 8139.118 \\
\hline 102 & 1 & & & & & & & & & & & & & $270+20$ & 38 & 4132.569 & 8139.117 \\
\hline 103 & & & 1 & & & 1 & & & & & & & & $269+90$ & 10 & 4132.566 & 8139.120 \\
\hline 104 & 1 & & & & & & & & & & & & & $269+90$ & 10 & 4132.567 & 8139.120 \\
\hline 105 & & & 1 & & & & & & & & & & & $269+90$ & 10 & 4132.567 & 8139.120 \\
\hline 106 & 1 & & & & & & & & & & & & & $269+90$ & 15 & 4132.567 & 8139.120 \\
\hline 107 & & & 1 & & & & & & & & & & & $269+90$ & 25 & 4132.568 & 8139.120 \\
\hline 108 & & & 1 & & & & & & & & & & & $269+90$ & 25 & 4132.566 & 8139.120 \\
\hline 109 & & & & & & & & 1 & & & & & & $269+90$ & 25 & 4132.570 & 8139.119 \\
\hline 110 & 1 & & & & & & & & & & & & & $269+90$ & 10 & 4132.565 & 8139.120 \\
\hline 111 & 1 & & & & & & & & & & & & & $269+90$ & 15 & 4132.565 & 8139.122 \\
\hline 112 & 1 & & & & & 1 & & & & & & & & $269+80$ & 10 & 4132.565 & 8139.123 \\
\hline 113 & & & 1 & & & & & & & & & & & $269+80$ & 15 & 4132.565 & 8139.123 \\
\hline 114 & 1 & & & & & & & & & & & & & $269+80$ & 20 & 4132.566 & 8139.122 \\
\hline
\end{tabular}




\begin{tabular}{|c|c|c|c|c|c|c|c|c|c|c|c|c|c|c|c|c|c|}
\hline \multirow[t]{2}{*}{$\begin{array}{l}\text { Dolos } \\
\text { Number }\end{array}$} & \multicolumn{13}{|c|}{ Break Type } & \multicolumn{4}{|c|}{ Location } \\
\hline & $\begin{array}{l}\text { Straight } \\
\text { Shank }\end{array}$ & $\begin{array}{l}\text { Straight } \\
\text { Mid } \\
\text { Shank }\end{array}$ & $\begin{array}{l}\text { Angled } \\
\text { Shank }\end{array}$ & $\begin{array}{l}\text { Angled } \\
\text { Mid } \\
\text { Shank }\end{array}$ & $\begin{array}{l}\text { Cracked } \\
\text { Shank }\end{array}$ & $\begin{array}{l}\text { Straight } \\
\text { Fluke }\end{array}$ & $\begin{array}{l}\text { Straight } \\
\text { Fluke } \\
\text { Tip }\end{array}$ & $\begin{array}{l}\text { Angled } \\
\text { Fluke }\end{array}$ & $\begin{array}{l}\text { Angled } \\
\text { Fluke } \\
\text { Tip }\end{array}$ & $\begin{array}{l}\text { Cracked } \\
\text { Fluke }\end{array}$ & $\begin{array}{l}\text { Damaged } \\
\text { Fluke }\end{array}$ & $\begin{array}{l}\text { Damaged/ } \\
\text { Broken } \\
\text { Fluke Tip }\end{array}$ & Pieces & $\begin{array}{l}\text { Station } \\
\text { Number }\end{array}$ & $\begin{array}{l}\text { Distance } \\
\text { from } \\
\text { Baseline }\end{array}$ & $\begin{array}{l}\text { GPS North } \\
\text { (Decimal } \\
\text { degrees) }\end{array}$ & $\begin{array}{l}\text { GPS 38st } \\
\text { (Decimal } \\
\text { degrees) }\end{array}$ \\
\hline 115 & & & 1 & & & & & & & & & & & $269+75$ & 20 & 4132.565 & 8139.124 \\
\hline 116 & & & 1 & & & & & & & & & & & $269+75$ & 38 & 4132.565 & 8139.124 \\
\hline 117 & & & & & & & & & & & & & 1 & $269+75$ & 15 & 4132.564 & 8139.125 \\
\hline 118 & 1 & & & & & & & & & & & & & $269+65$ & 38 & 4132.563 & 8139.126 \\
\hline 119 & 1 & & & & & & & & & & & & & $269+55$ & 15 & 4132.563 & 8139.127 \\
\hline 120 & 1 & & & & & & & & & & & & & $269+45$ & 10 & 4132.561 & 8139.129 \\
\hline 121 & & & 1 & & & & & & & & & & & $269+45$ & 25 & 4132.562 & 8139.131 \\
\hline 122 & & & 1 & & & & & 1 & & & & & & $269+45$ & 38 & & \\
\hline 123 & & & & & & & & 1 & & & & & & $269+45$ & 25 & & \\
\hline 124 & & & 1 & & & & & 1 & & & & & & $269+25$ & 15 & 4132.558 & 8139.134 \\
\hline 125 & & & 1 & & & & & 1 & & & & & & $269+25$ & 15 & 4132.559 & 8139.134 \\
\hline 126 & 1 & & & & & & & & & & & & & $269+25$ & 38 & 4132.560 & 8139.133 \\
\hline 127 & & & 1 & & & & & & & & & & & $269+15$ & 20 & 4132.558 & 8139.137 \\
\hline 128 & 1 & & & & & 1 & & & & & & & & $269+15$ & 20 & 4132.557 & 8139.137 \\
\hline 129 & & & 1 & & & 1 & & & & & & & & $269+15$ & 10 & 4132.557 & 8139.136 \\
\hline 130 & & & & & & 1 & & & & & & & & $269+05$ & 25 & 4132.557 & 8139.138 \\
\hline 131 & & & & & & 1 & & & & & & & & $268+95$ & 15 & 4132.556 & 8139.138 \\
\hline 132 & & & & 1 & & & & & & & & & & $268+95$ & 20 & 4132.556 & 8139.139 \\
\hline 133 & 1 & & & & & & & & & & & & & $268+90$ & 20 & 4132.556 & 8139.139 \\
\hline 134 & & 1 & & & & & & & & & & & & $268+95$ & 25 & 4132.557 & 8139.139 \\
\hline 135 & & & & & & 1 & & & & & & & & $268+95$ & 25 & 4132.556 & 8139.140 \\
\hline 136 & & & 1 & & & & & & & & & & & $268+85$ & 30 & 4132.555 & 8139.140 \\
\hline 137 & & & & & & 1 & & & & & & & & $268+85$ & 35 & 4132.555 & 8139.142 \\
\hline
\end{tabular}




\begin{tabular}{|c|c|c|c|c|c|c|c|c|c|c|c|c|c|c|c|c|c|}
\hline \multirow[t]{2}{*}{$\begin{array}{c}\text { Dolos } \\
\text { Number }\end{array}$} & \multicolumn{13}{|c|}{ Break Type } & \multicolumn{4}{|c|}{ Location } \\
\hline & $\begin{array}{l}\text { Straight } \\
\text { Shank }\end{array}$ & $\begin{array}{l}\text { Straight } \\
\text { Mid } \\
\text { Shank }\end{array}$ & $\begin{array}{l}\text { Angled } \\
\text { Shank }\end{array}$ & $\begin{array}{l}\text { Angled } \\
\text { Mid } \\
\text { Shank }\end{array}$ & $\begin{array}{l}\text { Cracked } \\
\text { Shank }\end{array}$ & $\begin{array}{l}\text { Straight } \\
\text { Fluke }\end{array}$ & $\begin{array}{c}\text { Straight } \\
\text { Fluke } \\
\text { Tip }\end{array}$ & $\begin{array}{c}\text { Angled } \\
\text { Fluke }\end{array}$ & $\begin{array}{c}\text { Angled } \\
\text { Fluke } \\
\text { Tip }\end{array}$ & $\begin{array}{l}\text { Cracked } \\
\text { Fluke }\end{array}$ & $\begin{array}{c}\text { Damaged } \\
\text { Fluke }\end{array}$ & $\begin{array}{c}\text { Damaged/ } \\
\text { Broken } \\
\text { Fluke Tip }\end{array}$ & Pieces & $\begin{array}{l}\text { Station } \\
\text { Number }\end{array}$ & $\begin{array}{l}\text { Distance } \\
\text { from } \\
\text { Baseline }\end{array}$ & $\begin{array}{c}\text { GPS North } \\
\text { (Decimal } \\
\text { degrees) }\end{array}$ & $\begin{array}{l}\text { GPS 38st } \\
\text { (Decimal } \\
\text { degrees) }\end{array}$ \\
\hline 138 & 1 & & & & & & & & & & & & & $268+85$ & 35 & 4132.554 & 8139.138 \\
\hline 139 & & & 1 & & & & & & & & & & & $268+90$ & 10 & 4132.555 & 8139.141 \\
\hline 140 & & & 1 & & & & & & & & & & & $268+85$ & 38 & 4132.554 & 8139.141 \\
\hline 141 & & & & & & 1 & & & & & & & & $268+80$ & 20 & 4132.554 & 8139.142 \\
\hline 142 & & & 1 & & & & & & & & & & & $268+75$ & 20 & 4132.554 & 8139.141 \\
\hline 143 & & & 1 & & & & & & & & & & & $268+75$ & 25 & 4132.552 & 8139.143 \\
\hline 144 & & & 1 & & & & & 1 & & & & & & $268+50$ & 15 & 4132.551 & 8139.145 \\
\hline 145 & & & & & & 1 & & & & & & & & $268+40$ & 20 & 4132.550 & 8139.144 \\
\hline 146 & 1 & & & & & & & & & & & & & $268+40$ & 0 & 4132.550 & 8139.147 \\
\hline 147 & 1 & & & & & & & & & & & & & $268+40$ & 0 & 4132.551 & 8139.148 \\
\hline 148 & & & & 1 & & & & & & & & & & $268+35$ & 15 & 4132.549 & 8139.148 \\
\hline 149 & 1 & & & & & & & & & & & & & $268+40$ & 25 & & \\
\hline 150 & & & & & & 1 & & & & & & & & $268+30$ & 10 & & \\
\hline 151 & & & & & & & & 1 & & & & & & $268+30$ & 25 & & \\
\hline 152 & & & 1 & & & & & & & & & & & $268+40$ & 30 & & \\
\hline 153 & & & & & & 1 & & & & & & & & $268+20$ & 25 & 4132.550 & 8139.150 \\
\hline 154 & 1 & & & & & & & & & & & & & $268+30$ & 25 & 4132.551 & 8139.150 \\
\hline 155 & 1 & & & & & & & & & & & & & $268+20$ & 20 & 4132.548 & 8139.150 \\
\hline 156 & & & & & & 1 & & & & & & & & $268+20$ & 15 & 4132.547 & 8139.150 \\
\hline 157 & & & & & & 1 & & & & & & & & $268+20$ & 15 & 4132.548 & 8139.149 \\
\hline 158 & 1 & & & & & 1 & & & & & & & & $268+20$ & 10 & 4132.547 & 8139.151 \\
\hline 159 & & & 1 & & & & & & & & & & & $268+10$ & 5 & 4132.546 & 8139.151 \\
\hline 160 & & & & & & 1 & & & & & & & & $268+05$ & 10 & 4132.547 & 8139.152 \\
\hline
\end{tabular}




\begin{tabular}{|c|c|c|c|c|c|c|c|c|c|c|c|c|c|c|c|c|c|}
\hline \multirow[t]{2}{*}{$\begin{array}{l}\text { Dolos } \\
\text { Number }\end{array}$} & \multicolumn{13}{|c|}{ Break Type } & \multicolumn{4}{|c|}{ Location } \\
\hline & $\begin{array}{l}\text { Straight } \\
\text { Shank }\end{array}$ & $\begin{array}{l}\text { Straight } \\
\text { Mid } \\
\text { Shank }\end{array}$ & $\begin{array}{l}\text { Angled } \\
\text { Shank }\end{array}$ & $\begin{array}{l}\text { Angled } \\
\text { Mid } \\
\text { Shank }\end{array}$ & $\begin{array}{l}\text { Cracked } \\
\text { Shank }\end{array}$ & $\begin{array}{l}\text { Straight } \\
\text { Fluke }\end{array}$ & $\begin{array}{l}\text { Straight } \\
\text { Fluke } \\
\text { Tip }\end{array}$ & $\begin{array}{l}\text { Angled } \\
\text { Fluke }\end{array}$ & $\begin{array}{l}\text { Angled } \\
\text { Fluke } \\
\text { Tip }\end{array}$ & $\begin{array}{l}\text { Cracked } \\
\text { Fluke }\end{array}$ & $\begin{array}{l}\text { Damaged } \\
\text { Fluke }\end{array}$ & $\begin{array}{l}\text { Damaged/ } \\
\text { Broken } \\
\text { Fluke Tip }\end{array}$ & Pieces & $\begin{array}{l}\text { Station } \\
\text { Number }\end{array}$ & $\begin{array}{l}\text { Distance } \\
\text { from } \\
\text { Baseline }\end{array}$ & $\begin{array}{l}\text { GPS North } \\
\text { (Decimal } \\
\text { degrees) }\end{array}$ & $\begin{array}{l}\text { GPS 38st } \\
\text { (Decimal } \\
\text { degrees) }\end{array}$ \\
\hline 161 & & & 1 & & & & & & & & & & & $268+05$ & 25 & 4132.547 & 8139.153 \\
\hline 162 & 1 & & & & & & & & & & & & & $268+10$ & 25 & 4132.548 & 8139.153 \\
\hline 163 & & & 1 & & & & & & & & & & & $268+10$ & 30 & 4132.548 & 8139.154 \\
\hline 164 & 1 & & & & & & & & & & & & & $268+20$ & 0 & & \\
\hline 165 & & & & & & & & 1 & & & & & & $268+00$ & 10 & 4132.546 & 8139.152 \\
\hline 166 & & & 1 & & & & & & & & & & & $267+95$ & 25 & 4132.546 & 8139.154 \\
\hline 167 & & & & & & & & 1 & & & & & & $267+90$ & 25 & 4132.547 & 8139.155 \\
\hline 168 & & & 1 & & & & & 1 & & & & & & $267+95$ & 25 & 4132.547 & 8139.154 \\
\hline 169 & & & & 1 & & & & & & & & & & $267+90$ & 25 & 4132.548 & 8139.154 \\
\hline 170 & 1 & & & & & & & & & & & & & $267+90$ & 20 & 4132.547 & 8139.154 \\
\hline 171 & 1 & & & & & & & & & & & & & $267+80$ & 20 & 4132.544 & 8139.158 \\
\hline 172 & 1 & & & & & & & & & & & & & $267+75$ & 20 & 4132.548 & 8139.156 \\
\hline 173 & 1 & & & & & & & & & & & & & $267+95$ & 20 & 4132.546 & 8139.156 \\
\hline 174 & & & & & & & & 1 & & & & & & $267+90$ & 30 & 4132.547 & 8139.157 \\
\hline 175 & 1 & & & & & & & & & & & & & $267+75$ & 30 & 4132.545 & 8139.158 \\
\hline 176 & & & 1 & & & & & & & & & & & $267+65$ & 30 & 4132.544 & 8139.160 \\
\hline 177 & & & & & & & & 1 & & & & & & $267+75$ & 15 & 4132.544 & 8139.157 \\
\hline 178 & & & 1 & & & & & & & & & & & $267+65$ & 25 & 4132.544 & 8139.158 \\
\hline 179 & 1 & & & & & & & & & & & & & $267+65$ & 30 & 4132.543 & 8139.159 \\
\hline 180 & 1 & & & & & & & & & & & & & $267+65$ & 25 & 4132.544 & 8139.159 \\
\hline 181 & & & & & & & & 1 & & & & & & $267+65$ & 38 & 4132.544 & 8139.159 \\
\hline 182 & & & & & & & & 1 & & & & & & $267+20$ & 20 & 4132.542 & 8139.160 \\
\hline 183 & & & 1 & & & 1 & & & & & & & & $267+55$ & 10 & 4132.541 & 8139.161 \\
\hline
\end{tabular}




\begin{tabular}{|c|c|c|c|c|c|c|c|c|c|c|c|c|c|c|c|c|c|}
\hline \multirow[t]{2}{*}{$\begin{array}{l}\text { Dolos } \\
\text { Number }\end{array}$} & \multicolumn{13}{|c|}{ Break Type } & \multicolumn{4}{|c|}{ Location } \\
\hline & $\begin{array}{l}\text { Straight } \\
\text { Shank }\end{array}$ & $\begin{array}{l}\text { Straight } \\
\text { Mid } \\
\text { Shank }\end{array}$ & $\begin{array}{l}\text { Angled } \\
\text { Shank }\end{array}$ & $\begin{array}{l}\text { Angled } \\
\text { Mid } \\
\text { Shank }\end{array}$ & $\begin{array}{l}\text { Cracked } \\
\text { Shank }\end{array}$ & $\begin{array}{l}\text { Straight } \\
\text { Fluke }\end{array}$ & $\begin{array}{l}\text { Straight } \\
\text { Fluke } \\
\text { Tip }\end{array}$ & $\begin{array}{l}\text { Angled } \\
\text { Fluke }\end{array}$ & $\begin{array}{l}\text { Angled } \\
\text { Fluke } \\
\text { Tip }\end{array}$ & $\begin{array}{l}\text { Cracked } \\
\text { Fluke }\end{array}$ & $\begin{array}{l}\text { Damaged } \\
\text { Fluke }\end{array}$ & $\begin{array}{l}\text { Damaged/ } \\
\text { Broken } \\
\text { Fluke Tip }\end{array}$ & Pieces & $\begin{array}{l}\text { Station } \\
\text { Number }\end{array}$ & $\begin{array}{l}\text { Distance } \\
\text { from } \\
\text { Baseline }\end{array}$ & $\begin{array}{l}\text { GPS North } \\
\text { (Decimal } \\
\text { degrees) }\end{array}$ & $\begin{array}{l}\text { GPS 38st } \\
\text { (Decimal } \\
\text { degrees) }\end{array}$ \\
\hline 184 & 1 & & & & & & & & & & & & & $267+55$ & 25 & 4132.540 & 8139.162 \\
\hline 185 & 1 & & & & & 1 & & & & & & & & $267+55$ & 10 & 4132.540 & 8139.161 \\
\hline 186 & 1 & & & & & & & & & & & & & $267+55$ & 38 & & \\
\hline 187 & & & & & & & & 1 & & & & & & $267+40$ & 15 & 4132.540 & 8139.163 \\
\hline 188 & & & 1 & & & & & & & & & & & $267+40$ & 20 & 4132.540 & 8139.163 \\
\hline 189 & & & 1 & & & & & 1 & & & & & & $267+50$ & 15 & 4132.540 & 8139.161 \\
\hline 190 & & & & & & & & 1 & & & & & & $267+55$ & 15 & 4132.541 & 8139.161 \\
\hline 191 & 1 & & & & & & & & & & & & & $267+55$ & 15 & 4132.541 & 8139.161 \\
\hline 192 & 1 & & & & & & & & & & & & & $267+40$ & 20 & 4132.540 & 8139.163 \\
\hline 193 & & & 1 & & & & & & & & & & & $267+30$ & 20 & 4132.540 & 8139.165 \\
\hline 194 & & & & 1 & & & & & & & & & & $267+20$ & 20 & 4132.539 & 8139.164 \\
\hline 195 & & & & 1 & & & & & & & & & & $267+30$ & 25 & 4132.540 & 8139.165 \\
\hline 196 & 1 & & & & & & & & & & & & & $267+20$ & 20 & 4132.539 & 8139.165 \\
\hline 197 & 1 & & & & & & & & & & & & & $267+20$ & 25 & 4132.539 & 8139.166 \\
\hline 198 & 1 & & & & & & & & & & & & & $267+15$ & 25 & & \\
\hline 199 & 1 & & & & & & & & & & & & & $267+20$ & 38 & 4132.538 & 8139.167 \\
\hline 200 & & & 1 & & & 1 & & & & & & & & $267+15$ & 20 & 4132.538 & 8139.167 \\
\hline 201 & & & & & & & & 1 & & & & & & $267+20$ & 25 & & \\
\hline 202 & & & & & & & & & & & & & 1 & $267+15$ & 30 & & \\
\hline 203 & 1 & & & & & & & & & & & & & $267+00$ & 10 & 4132.537 & 8139.167 \\
\hline 204 & & & 1 & & & & & & & & & & & $267+00$ & 15 & 4132.536 & 8139.170 \\
\hline 205 & 1 & & & & & & & & & & & & & $267+00$ & 25 & 4132.537 & 8139.168 \\
\hline 206 & 1 & & & & & & & & & & & & & $267+00$ & 20 & 4132.537 & 8139.169 \\
\hline
\end{tabular}




\begin{tabular}{|c|c|c|c|c|c|c|c|c|c|c|c|c|c|c|c|c|c|}
\hline \multirow[t]{2}{*}{$\begin{array}{c}\text { Dolos } \\
\text { Number }\end{array}$} & \multicolumn{13}{|c|}{ Break Type } & \multicolumn{4}{|c|}{ Location } \\
\hline & $\begin{array}{l}\text { Straight } \\
\text { Shank }\end{array}$ & $\begin{array}{l}\text { Straight } \\
\text { Mid } \\
\text { Shank }\end{array}$ & $\begin{array}{l}\text { Angled } \\
\text { Shank }\end{array}$ & $\begin{array}{c}\text { Angled } \\
\text { Mid } \\
\text { Shank }\end{array}$ & $\begin{array}{l}\text { Cracked } \\
\text { Shank }\end{array}$ & $\begin{array}{l}\text { Straight } \\
\text { Fluke }\end{array}$ & $\begin{array}{l}\text { Straight } \\
\text { Fluke } \\
\text { Tip }\end{array}$ & $\begin{array}{l}\text { Angled } \\
\text { Fluke }\end{array}$ & $\begin{array}{c}\text { Angled } \\
\text { Fluke } \\
\text { Tip }\end{array}$ & $\begin{array}{c}\text { Cracked } \\
\text { Fluke }\end{array}$ & $\begin{array}{l}\text { Damaged } \\
\text { Fluke }\end{array}$ & $\begin{array}{c}\text { Damaged/ } \\
\text { Broken } \\
\text { Fluke Tip }\end{array}$ & Pieces & $\begin{array}{l}\text { Station } \\
\text { Number }\end{array}$ & $\begin{array}{l}\text { Distance } \\
\text { from } \\
\text { Baseline }\end{array}$ & $\begin{array}{l}\text { GPS North } \\
\text { (Decimal } \\
\text { degrees) }\end{array}$ & $\begin{array}{l}\text { GPS 38st } \\
\text { (Decimal } \\
\text { degrees) }\end{array}$ \\
\hline 207 & 1 & & & & & & & & & & & & & $267+15$ & 25 & & \\
\hline 208 & 1 & & & & & & & & & & & & & $266+90$ & 15 & 4132.535 & 8139.172 \\
\hline 209 & & & & & & 1 & & & & & & & & $266+70$ & 15 & 4132.534 & 8139.173 \\
\hline 210 & & & & & & & & 1 & & & & & & $267+00$ & 25 & 4132.537 & 8139.171 \\
\hline 211 & & & 1 & & & & & & & & & & & $266+70$ & 15 & 4132.535 & 8139.173 \\
\hline 212 & & & & & & & & 1 & & & & & & $266+70$ & 15 & 4132.532 & 8139.174 \\
\hline 213 & 1 & & & & & & & 1 & & & & & & $266+70$ & 15 & 4132.534 & 8139.173 \\
\hline 214 & & & 1 & & & & & 1 & & & & & & $266+70$ & 20 & 4132.535 & 8139.174 \\
\hline 215 & & & & & & & & 1 & & & & & & $266+70$ & 25 & 4132.535 & 8139.174 \\
\hline 216 & & & & & & & & 1 & & & & & & $266+70$ & 20 & 4132.535 & 8139.173 \\
\hline 217 & & & 1 & & & & & 1 & & & & & & $266+70$ & 25 & 4132.536 & 8139.173 \\
\hline 218 & & & 1 & & & & & 1 & & & & & & $266+70$ & 25 & & \\
\hline 219 & & & 1 & & & & & & & & & & & $266+70$ & 20 & 4132.533 & 8139.176 \\
\hline 220 & & & & & & & & 1 & & & & & & $266+55$ & 15 & 4132.534 & 8139.175 \\
\hline 221 & 1 & & & & & 1 & & & & & & & & $266+55$ & 38 & 4132.534 & 8139.176 \\
\hline 222 & & & & & & 1 & & & & & & & & $266+35$ & 10 & 4132.532 & 8139.180 \\
\hline 223 & & & & & & & & 2 & & & & & & $266+35$ & 10 & 4132.530 & 8139.180 \\
\hline 224 & & & 1 & & & & & & & & & & & $266+20$ & 20 & 4132.531 & 8139.182 \\
\hline 225 & & & 1 & & & & & & & & & & & $266+05$ & 15 & 4132.531 & 8139.178 \\
\hline 226 & 1 & & & & & & & & & & & & & $266+05$ & 15 & 4132.530 & 8139.180 \\
\hline 227 & & & 1 & & & & & & & & & & & $266+10$ & 15 & 4132.530 & 8139.182 \\
\hline 228 & 1 & & & & & & & & & & & & & $266+10$ & 30 & & \\
\hline 229 & & & 1 & & & & & & & & & & & $265+95$ & 10 & 4132.529 & 8139.181 \\
\hline
\end{tabular}




\begin{tabular}{|c|c|c|c|c|c|c|c|c|c|c|c|c|c|c|c|c|c|}
\hline \multirow[t]{2}{*}{$\begin{array}{l}\text { Dolos } \\
\text { Number }\end{array}$} & \multicolumn{13}{|c|}{ Break Type } & \multicolumn{4}{|c|}{ Location } \\
\hline & $\begin{array}{l}\text { Straight } \\
\text { Shank }\end{array}$ & $\begin{array}{l}\text { Straight } \\
\text { Mid } \\
\text { Shank }\end{array}$ & $\begin{array}{l}\text { Angled } \\
\text { Shank }\end{array}$ & $\begin{array}{l}\text { Angled } \\
\text { Mid } \\
\text { Shank }\end{array}$ & $\begin{array}{l}\text { Cracked } \\
\text { Shank }\end{array}$ & $\begin{array}{l}\text { Straight } \\
\text { Fluke }\end{array}$ & $\begin{array}{l}\text { Straight } \\
\text { Fluke } \\
\text { Tip }\end{array}$ & $\begin{array}{l}\text { Angled } \\
\text { Fluke }\end{array}$ & $\begin{array}{l}\text { Angled } \\
\text { Fluke } \\
\text { Tip }\end{array}$ & $\begin{array}{l}\text { Cracked } \\
\text { Fluke }\end{array}$ & $\begin{array}{l}\text { Damaged } \\
\text { Fluke }\end{array}$ & $\begin{array}{l}\text { Damaged/ } \\
\text { Broken } \\
\text { Fluke Tip }\end{array}$ & Pieces & $\begin{array}{l}\text { Station } \\
\text { Number }\end{array}$ & $\begin{array}{l}\text { Distance } \\
\text { from } \\
\text { Baseline }\end{array}$ & $\begin{array}{l}\text { GPS North } \\
\text { (Decimal } \\
\text { degrees) }\end{array}$ & $\begin{array}{l}\text { GPS 38st } \\
\text { (Decimal } \\
\text { degrees) }\end{array}$ \\
\hline 230 & & 1 & & & & & & & & & & & & $265+95$ & 25 & 4132.528 & 8139.186 \\
\hline 231 & 1 & & & & & & & & & & & & & $265+95$ & 25 & 4132.529 & 8139.185 \\
\hline 232 & 1 & & & & & & & & & & & & & $265+95$ & 25 & 4132.530 & 8139.183 \\
\hline 233 & & & & & & & & 1 & & & & & & $265+95$ & 25 & 4132.528 & 8139.187 \\
\hline 234 & & & & & & & & 2 & & & & & & $265+95$ & 25 & & \\
\hline 235 & & & 1 & & & & & & & & & & & $265+95$ & 38 & & \\
\hline 236 & & & & & & & & 1 & & & & & & $265+80$ & 30 & 4132.529 & 8139.189 \\
\hline 237 & & & 1 & & & & & & & & & & & $265+80$ & 30 & 4132.529 & 8139.189 \\
\hline 238 & & & & & & 1 & & 1 & & & & & & $265+65$ & 38 & 4132.526 & 8139.190 \\
\hline 239 & 1 & & & & & & & & & & & & & $265+65$ & 20 & 4132.525 & 8139.191 \\
\hline 240 & & & 1 & & & & & & & & & & & $265+65$ & 25 & 4132.525 & 8139.191 \\
\hline 241 & & & 1 & & & & & 1 & & & & & & $265+65$ & 25 & 4132.525 & 8139.191 \\
\hline 242 & & & & & & & & 1 & & & & & & $265+60$ & 30 & & \\
\hline 243 & & & & & & & & 1 & & & & & & $265+60$ & 10 & 4132.523 & 8139.191 \\
\hline 244 & & & & & & 1 & & & & & & & & $265+65$ & 25 & 4132.524 & 8139.193 \\
\hline 245 & & & & & & & & 1 & & & & & & $265+65$ & 20 & 4132.525 & 8139.192 \\
\hline 246 & & & 1 & & & & & 1 & & & & & & $265+65$ & 20 & 4132.524 & 8139.194 \\
\hline 247 & & & 1 & & & & & & & & & & & $265+50$ & 25 & 4132.523 & 8139.195 \\
\hline 248 & & & 1 & & & & & & & & & & & $265+65$ & 30 & 4132.523 & 8139.195 \\
\hline 249 & 1 & & & & & & & & & & & & & $265+65$ & 38 & & \\
\hline 250 & 1 & & & & & 1 & & & & & & & & $265+35$ & 25 & 4132.521 & 8139.195 \\
\hline 251 & & & & & & & & & & & & 1 & & $265+30$ & 30 & 4132.523 & 8139.198 \\
\hline 252 & & & 1 & & & & & & & & & & & $265+30$ & 10 & 4132.521 & 8139.198 \\
\hline
\end{tabular}




\begin{tabular}{|c|c|c|c|c|c|c|c|c|c|c|c|c|c|c|c|c|c|}
\hline \multirow[t]{2}{*}{$\begin{array}{l}\text { Dolos } \\
\text { Number }\end{array}$} & \multicolumn{13}{|c|}{ Break Type } & \multicolumn{4}{|c|}{ Location } \\
\hline & $\begin{array}{l}\text { Straight } \\
\text { Shank }\end{array}$ & $\begin{array}{l}\text { Straight } \\
\text { Mid } \\
\text { Shank }\end{array}$ & $\begin{array}{l}\text { Angled } \\
\text { Shank }\end{array}$ & $\begin{array}{l}\text { Angled } \\
\text { Mid } \\
\text { Shank }\end{array}$ & $\begin{array}{l}\text { Cracked } \\
\text { Shank }\end{array}$ & $\begin{array}{l}\text { Straight } \\
\text { Fluke }\end{array}$ & $\begin{array}{l}\text { Straight } \\
\text { Fluke } \\
\text { Tip }\end{array}$ & $\begin{array}{l}\text { Angled } \\
\text { Fluke }\end{array}$ & $\begin{array}{l}\text { Angled } \\
\text { Fluke } \\
\text { Tip }\end{array}$ & $\begin{array}{l}\text { Cracked } \\
\text { Fluke }\end{array}$ & $\begin{array}{l}\text { Damaged } \\
\text { Fluke }\end{array}$ & $\begin{array}{c}\text { Damaged/ } \\
\text { Broken } \\
\text { Fluke Tip }\end{array}$ & Pieces & $\begin{array}{l}\text { Station } \\
\text { Number }\end{array}$ & $\begin{array}{l}\text { Distance } \\
\text { from } \\
\text { Baseline }\end{array}$ & $\begin{array}{c}\text { GPS North } \\
\text { (Decimal } \\
\text { degrees) }\end{array}$ & $\begin{array}{l}\text { GPS 38st } \\
\text { (Decimal } \\
\text { degrees) }\end{array}$ \\
\hline 253 & & & & & & & & 1 & & & & & & $265+30$ & 35 & & \\
\hline 254 & 1 & & & & & & & & & & & & & $265+15$ & 15 & 4132.519 & 8139.200 \\
\hline 255 & 1 & & & & & & & & & & & & & $265+15$ & 20 & 4132.519 & 8139.202 \\
\hline 256 & & & & & & & & & & & & & 1 & $265+10$ & 30 & 4132.518 & 8139.202 \\
\hline 257 & & & & & & & & 1 & & & & & & $265+10$ & 38 & 4132.519 & 8139.201 \\
\hline 258 & & & 1 & & & & & & & & & & & $265+10$ & 15 & 4132.518 & 8139.203 \\
\hline 259 & 1 & & & & & & & & & & & & & $265+10$ & 38 & 4132.519 & 8139.201 \\
\hline 260 & & & 1 & & & & & & & & & & & $264+90$ & 20 & 4132.517 & 8139.205 \\
\hline 261 & & & & & & & & 1 & & & & & & $264+90$ & 38 & 4132.517 & 8139.205 \\
\hline 262 & & & 1 & & & & & & & & & & & $264+75$ & 15 & 4132.517 & 8139.204 \\
\hline 263 & 1 & & & & & & & & & & & & & $264+75$ & 25 & & \\
\hline 264 & 1 & & 1 & & & & & & & & & & & $264+70$ & 25 & 4132.514 & 8139.206 \\
\hline 265 & & & 1 & & & & & & & & & & & $264+75$ & 25 & & \\
\hline 266 & 1 & & & & & & & & & & & & & $264+65$ & 10 & 4132.513 & 8139.207 \\
\hline 267 & & & 1 & & & & & & & & & & & $264+65$ & 20 & 4132.517 & 8139.206 \\
\hline 268 & 1 & & & & & & & & & & & & & $264+65$ & 20 & 4132.512 & 8139.209 \\
\hline 269 & & & & & & & & 1 & & & & & & $264+65$ & 20 & 4132.514 & 8139.208 \\
\hline 270 & & & & & & & & 1 & & & & & & $264+55$ & 25 & 4132.514 & 8139.210 \\
\hline 271 & & & & & & & & 1 & & & & & & $264+65$ & 38 & 4132.514 & 8139.212 \\
\hline 272 & & & & & & 1 & & & & & & & & $264+65$ & 38 & & \\
\hline 273 & & & 1 & & & & & & & & & & & $264+55$ & 30 & 4132.511 & 8139.215 \\
\hline 274 & & & 1 & & & & & & & & & & & $264+55$ & 30 & 4132.511 & 8139.215 \\
\hline 275 & & & 1 & & & & & & & & & & & $264+40$ & 38 & 4132.511 & 8139.214 \\
\hline
\end{tabular}




\begin{tabular}{|c|c|c|c|c|c|c|c|c|c|c|c|c|c|c|c|c|c|}
\hline \multirow[t]{2}{*}{$\begin{array}{l}\text { Dolos } \\
\text { Number }\end{array}$} & \multicolumn{13}{|c|}{ Break Type } & \multicolumn{4}{|c|}{ Location } \\
\hline & $\begin{array}{l}\text { Straight } \\
\text { Shank }\end{array}$ & $\begin{array}{l}\text { Straight } \\
\text { Mid } \\
\text { Shank }\end{array}$ & $\begin{array}{l}\text { Angled } \\
\text { Shank }\end{array}$ & $\begin{array}{l}\text { Angled } \\
\text { Mid } \\
\text { Shank }\end{array}$ & $\begin{array}{l}\text { Cracked } \\
\text { Shank }\end{array}$ & $\begin{array}{l}\text { Straight } \\
\text { Fluke }\end{array}$ & $\begin{array}{l}\text { Straight } \\
\text { Fluke } \\
\text { Tip }\end{array}$ & $\begin{array}{l}\text { Angled } \\
\text { Fluke }\end{array}$ & $\begin{array}{l}\text { Angled } \\
\text { Fluke } \\
\text { Tip }\end{array}$ & $\begin{array}{l}\text { Cracked } \\
\text { Fluke }\end{array}$ & $\begin{array}{l}\text { Damaged } \\
\text { Fluke }\end{array}$ & $\begin{array}{l}\text { Damaged/ } \\
\text { Broken } \\
\text { Fluke Tip }\end{array}$ & Pieces & $\begin{array}{l}\text { Station } \\
\text { Number }\end{array}$ & $\begin{array}{l}\text { Distance } \\
\text { from } \\
\text { Baseline }\end{array}$ & $\begin{array}{l}\text { GPS North } \\
\text { (Decimal } \\
\text { degrees) }\end{array}$ & $\begin{array}{l}\text { GPS 38st } \\
\text { (Decimal } \\
\text { degrees) }\end{array}$ \\
\hline 276 & 1 & & & & & & & & & & & & & $264+40$ & 38 & 4132.511 & 8139.214 \\
\hline 277 & 1 & & & & & & & & & & & & & $264+40$ & 5 & 4132.509 & 8139.214 \\
\hline 278 & 1 & & & & & & & & & & & & & $264+25$ & 10 & 4132.507 & 8139.216 \\
\hline 279 & & & & & & & & 1 & & & & & & $264+25$ & 15 & 4132.509 & 8139.215 \\
\hline 280 & & & & & & & & 1 & & & & & & $264+25$ & 20 & 4132.511 & 8139.214 \\
\hline 281 & & & & & & & & 1 & & & & & & $264+25$ & 30 & 4132.510 & 8139.218 \\
\hline 282 & & & & & & & & 1 & & & & & & $264+25$ & 25 & 4132.510 & 8139.218 \\
\hline 283 & & & & & & & & 1 & & & & & & $264+15$ & 38 & 4132.510 & 8139.218 \\
\hline 284 & & & & & & 1 & & & & & & & & $264+15$ & 30 & 4132.509 & 8139.219 \\
\hline 285 & & & & & & 1 & & & & & & & & $264+15$ & 20 & 4132.509 & 8139.218 \\
\hline 286 & & & & & & & & 1 & & & & & & $263+90$ & 38 & 4132.506 & 8139.223 \\
\hline 287 & & & & & & & & 1 & & & & & & $263+80$ & 38 & 4132.506 & 8139.224 \\
\hline 288 & 1 & & & & & & & & & & & & & $263+90$ & 38 & 4132.508 & 8139.222 \\
\hline 289 & 1 & & & & & & & & & & & & & $263+70$ & 15 & 4132.502 & 8139.230 \\
\hline 290 & & & & & & & & 1 & & & & & & $263+60$ & 10 & & \\
\hline 291 & & & & & & & & 1 & & & & & & $263+60$ & 38 & & \\
\hline 292 & & & 1 & & & & & & & & & & & $263+60$ & 38 & & \\
\hline 293 & & & 1 & & & & & & & & & & & $263+50$ & 20 & 4132.504 & 8139.229 \\
\hline 294 & & & & & & & & 2 & & & & & & $263+40$ & 20 & 4132.500 & 8139.234 \\
\hline 295 & & & 1 & & & & & & & & & & & $263+40$ & 15 & 4132.499 & 8139.235 \\
\hline 296 & & & & & & & & 1 & & & & & & $263+65$ & 15 & 4132.505 & 8139.227 \\
\hline 297 & 1 & & & & & & & & & & & & & $263+40$ & 15 & 4132.500 & 8139.234 \\
\hline 298 & & & 1 & & & & & & & & & & & $263+30$ & 10 & 4132.496 & 8139.237 \\
\hline
\end{tabular}




\begin{tabular}{|c|c|c|c|c|c|c|c|c|c|c|c|c|c|c|c|c|c|}
\hline \multirow[t]{2}{*}{$\begin{array}{c}\text { Dolos } \\
\text { Number }\end{array}$} & \multicolumn{13}{|c|}{ Break Type } & \multicolumn{4}{|c|}{ Location } \\
\hline & $\begin{array}{l}\text { Straight } \\
\text { Shank }\end{array}$ & $\begin{array}{l}\text { Straight } \\
\text { Mid } \\
\text { Shank }\end{array}$ & $\begin{array}{l}\text { Angled } \\
\text { Shank }\end{array}$ & $\begin{array}{l}\text { Angled } \\
\text { Mid } \\
\text { Shank }\end{array}$ & $\begin{array}{l}\text { Cracked } \\
\text { Shank }\end{array}$ & $\begin{array}{l}\text { Straight } \\
\text { Fluke }\end{array}$ & $\begin{array}{l}\text { Straight } \\
\text { Fluke } \\
\text { Tip }\end{array}$ & $\begin{array}{l}\text { Angled } \\
\text { Fluke }\end{array}$ & $\begin{array}{l}\text { Angled } \\
\text { Fluke } \\
\text { Tip }\end{array}$ & $\begin{array}{l}\text { Cracked } \\
\text { Fluke }\end{array}$ & $\begin{array}{l}\text { Damaged } \\
\text { Fluke }\end{array}$ & $\begin{array}{c}\text { Damaged/ } \\
\text { Broken } \\
\text { Fluke Tip }\end{array}$ & Pieces & $\begin{array}{l}\text { Station } \\
\text { Number }\end{array}$ & $\begin{array}{l}\text { Distance } \\
\text { from } \\
\text { Baseline }\end{array}$ & $\begin{array}{c}\text { GPS North } \\
\text { (Decimal } \\
\text { degrees) }\end{array}$ & $\begin{array}{l}\text { GPS 38st } \\
\text { (Decimal } \\
\text { degrees) }\end{array}$ \\
\hline 299 & & & 1 & & & & & & & & & & & $263+25$ & 10 & 4132.497 & 8139.236 \\
\hline 300 & & & & & & & & 1 & & & & & & $263+20$ & 25 & 4132.498 & 8139.238 \\
\hline 301 & & & 1 & & & & & & & & & & & $263+25$ & 38 & & \\
\hline 302 & & & & & & & & 1 & & & & & & $263+30$ & 38 & 4132.499 & 8139.237 \\
\hline 303 & 1 & & & & & & & & & & & & & $263+05$ & 20 & 4132.495 & 8139.241 \\
\hline 304 & & & & & & & & 1 & & & & & & $263+00$ & 38 & 4132.495 & 8139.242 \\
\hline 305 & & & 1 & & & & & & & & & & & $262+95$ & 20 & 4132.494 & 8139.243 \\
\hline 306 & & & 1 & & & & & & & & & & & $262+50$ & 20 & 4132.494 & 8139.244 \\
\hline 307 & & & & & & & & 2 & & & & & & $262+75$ & 10 & 4132.493 & 8139.246 \\
\hline 308 & 1 & & & & & & & & & & & & & $262+75$ & 10 & 4132.493 & 8139.246 \\
\hline 309 & & & & & & 1 & & & & & & & & $262+75$ & 10 & 4132.491 & 8139.247 \\
\hline 310 & & & & & 1 & & & & & 1 & & & & $262+75$ & 10 & 4132.493 & 8139.246 \\
\hline 311 & 1 & & 1 & & & & & & & & & & & $262+75$ & 20 & 4132.493 & 8139.246 \\
\hline 312 & 1 & & & & & & & 1 & & & & & & $262+70$ & 20 & 4132.492 & 8139.247 \\
\hline 313 & & & & & & 1 & & & & & & & & $262+55$ & 15 & 4132.491 & 8139.248 \\
\hline 314 & & & 1 & & & & & & & & & & & $262+55$ & 15 & 4132.491 & 8139.251 \\
\hline 315 & & & 1 & & & & & & & & & & & $262+50$ & 10 & 4132.491 & 8139.248 \\
\hline 316 & & & & & & & & 1 & & & & & & $262+50$ & 15 & 4132.491 & 8139.251 \\
\hline 317 & & & & & & & & 1 & & & & & & $262+55$ & 25 & 4132.492 & 8139.251 \\
\hline 318 & 1 & & & & & & & 1 & & & & & & $262+45$ & 20 & & \\
\hline 319 & 1 & & & & & & & & & & & & & $262+55$ & 25 & 4132.491 & 8139.252 \\
\hline 320 & 1 & & & & & & & & & & & & & $262+35$ & 25 & & \\
\hline 321 & 2 & & & & & & & & & & & & & $262+65$ & 20 & 4132.491 & 8139.251 \\
\hline
\end{tabular}




\begin{tabular}{|c|c|c|c|c|c|c|c|c|c|c|c|c|c|c|c|c|c|}
\hline \multirow[t]{2}{*}{$\begin{array}{l}\text { Dolos } \\
\text { Number }\end{array}$} & \multicolumn{13}{|c|}{ Break Type } & \multicolumn{4}{|c|}{ Location } \\
\hline & $\begin{array}{l}\text { Straight } \\
\text { Shank }\end{array}$ & $\begin{array}{l}\text { Straight } \\
\text { Mid } \\
\text { Shank }\end{array}$ & $\begin{array}{l}\text { Angled } \\
\text { Shank }\end{array}$ & $\begin{array}{l}\text { Angled } \\
\text { Mid } \\
\text { Shank }\end{array}$ & $\begin{array}{l}\text { Cracked } \\
\text { Shank }\end{array}$ & $\begin{array}{l}\text { Straight } \\
\text { Fluke }\end{array}$ & $\begin{array}{l}\text { Straight } \\
\text { Fluke } \\
\text { Tip }\end{array}$ & $\begin{array}{l}\text { Angled } \\
\text { Fluke }\end{array}$ & $\begin{array}{l}\text { Angled } \\
\text { Fluke } \\
\text { Tip }\end{array}$ & $\begin{array}{l}\text { Cracked } \\
\text { Fluke }\end{array}$ & $\begin{array}{l}\text { Damaged } \\
\text { Fluke }\end{array}$ & $\begin{array}{l}\text { Damaged/ } \\
\text { Broken } \\
\text { Fluke Tip }\end{array}$ & Pieces & $\begin{array}{l}\text { Station } \\
\text { Number }\end{array}$ & $\begin{array}{l}\text { Distance } \\
\text { from } \\
\text { Baseline }\end{array}$ & $\begin{array}{l}\text { GPS North } \\
\text { (Decimal } \\
\text { degrees) }\end{array}$ & $\begin{array}{l}\text { GPS 38st } \\
\text { (Decimal } \\
\text { degrees) }\end{array}$ \\
\hline 322 & & & 1 & & & & & 1 & & & & & & $262+30$ & 20 & 4132.489 & 8139.255 \\
\hline 323 & 1 & & 1 & & & & & & & & & & & $262+30$ & 25 & & \\
\hline 324 & & & 1 & & & & & & & & & & & $262+10$ & 5 & & \\
\hline 325 & & & 1 & & & & & & & & & & & $262+10$ & 20 & 4132.488 & 8139.257 \\
\hline 326 & 1 & & & 1 & & 1 & & & & & & & & $262+20$ & 20 & 4132.488 & 8139.257 \\
\hline 327 & & & 1 & & & & & & & & & & & $262+15$ & 25 & 4132.488 & 8139.259 \\
\hline 328 & & & 1 & & & & & & & & & & & $262+20$ & 38 & & \\
\hline 329 & 1 & & & & & & & & & & & & & $262+00$ & 30 & 4132.486 & 8139.261 \\
\hline 330 & 1 & & & & & & & & & & & & & $262+00$ & 20 & 4132.485 & 8139.260 \\
\hline 331 & & & & & & & & 1 & & & & & & $262+10$ & 30 & 4132.487 & 8139.259 \\
\hline 332 & 1 & & & & & & & & & & & & & $262+00$ & 30 & 4132.484 & 8139.261 \\
\hline 333 & & & & 1 & & & & & & & & & & $262+00$ & 20 & 4132.483 & 8139.261 \\
\hline 334 & & & & & & 2 & & & & & & & & $262+00$ & 10 & 4132.483 & 8139.260 \\
\hline 335 & 1 & & & & & & & & & & & & & $261+85$ & 15 & 4132.481 & 8139.264 \\
\hline 336 & & & 1 & & & & & & & & & & & $261+85$ & 15 & 4132.482 & 8139.264 \\
\hline 337 & & & & & & & & 2 & & & & & & $261+75$ & 15 & 4132.482 & 8139.267 \\
\hline 338 & & & & 2 & & & & & & & & & & $261+65$ & 15 & 4132.481 & 8139.268 \\
\hline 339 & 2 & & & & & & & & & & & & & $261+65$ & 15 & 4132.481 & 8139.267 \\
\hline 340 & & & 1 & & & & & & & & & & & $261+55$ & 15 & 4132.481 & 8139.269 \\
\hline 341 & & & & & & 1 & & & & & & & & $261+40$ & 10 & 4132.479 & 8139.271 \\
\hline 342 & & & & & & & & 1 & & & & & & $261+40$ & 10 & 4132.478 & 8139.272 \\
\hline 343 & & & 1 & & & & & & & & & & & $261+30$ & 10 & 4132.479 & 8139.272 \\
\hline 344 & 1 & & & & & & & & & & & & & $261+05$ & 15 & 4132.472 & 8139.280 \\
\hline
\end{tabular}




\begin{tabular}{|c|c|c|c|c|c|c|c|c|c|c|c|c|c|c|c|c|c|}
\hline \multirow[t]{2}{*}{$\begin{array}{c}\text { Dolos } \\
\text { Number }\end{array}$} & \multicolumn{13}{|c|}{ Break Type } & \multicolumn{4}{|c|}{ Location } \\
\hline & $\begin{array}{l}\text { Straight } \\
\text { Shank }\end{array}$ & $\begin{array}{l}\text { Straight } \\
\text { Mid } \\
\text { Shank }\end{array}$ & $\begin{array}{l}\text { Angled } \\
\text { Shank }\end{array}$ & $\begin{array}{c}\text { Angled } \\
\text { Mid } \\
\text { Shank }\end{array}$ & $\begin{array}{l}\text { Cracked } \\
\text { Shank }\end{array}$ & $\begin{array}{l}\text { Straight } \\
\text { Fluke }\end{array}$ & $\begin{array}{l}\text { Straight } \\
\text { Fluke } \\
\text { Tip }\end{array}$ & $\begin{array}{l}\text { Angled } \\
\text { Fluke }\end{array}$ & $\begin{array}{c}\text { Angled } \\
\text { Fluke } \\
\text { Tip }\end{array}$ & $\begin{array}{c}\text { Cracked } \\
\text { Fluke }\end{array}$ & $\begin{array}{l}\text { Damaged } \\
\text { Fluke }\end{array}$ & $\begin{array}{c}\text { Damaged/ } \\
\text { Broken } \\
\text { Fluke Tip }\end{array}$ & Pieces & $\begin{array}{l}\text { Station } \\
\text { Number }\end{array}$ & $\begin{array}{l}\text { Distance } \\
\text { from } \\
\text { Baseline }\end{array}$ & $\begin{array}{c}\text { GPS North } \\
\text { (Decimal } \\
\text { degrees) }\end{array}$ & $\begin{array}{l}\text { GPS 38st } \\
\text { (Decimal } \\
\text { degrees) }\end{array}$ \\
\hline 345 & 1 & & & & & & & & & & & & & $260+95$ & 10 & 4132.474 & 8139.280 \\
\hline 346 & & & 1 & & & & & & & & & & & $261+05$ & 5 & 4132.474 & 8139.278 \\
\hline 347 & & & & & & & & 1 & & & & & & $260+85$ & 15 & 4132.472 & 8139.281 \\
\hline 348 & 1 & & & & & & & & & & & & & $260+85$ & 10 & 4132.471 & 8139.282 \\
\hline 349 & & & 1 & & & & & & & & & & & $260+80$ & 5 & 4132.471 & 8139.282 \\
\hline 350 & & & 1 & & & & & & & & & & & $260+85$ & 20 & 4132.472 & 8139.283 \\
\hline 351 & 1 & & & & & & & & & & & & & $260+85$ & 25 & 4132.472 & 8139.282 \\
\hline 352 & & & 1 & & & & & & & & & & & $260+75$ & 15 & 4132.471 & 8139.284 \\
\hline 353 & 2 & & & & & & & & & & & & & $260+70$ & 20 & 4132.471 & 8139.284 \\
\hline 354 & 1 & & & & & & & & & & & & & $260+70$ & 20 & 4132.472 & 8139.284 \\
\hline 355 & & & 1 & & & & & & & & & & & $260+70$ & 20 & 4132.472 & 8139.284 \\
\hline 356 & & & 1 & & & & & & & & & & & $260+60$ & 10 & 4132.470 & 8139.285 \\
\hline 357 & 1 & & & & & & & & & & & & & $260+50$ & 35 & 4132.469 & 8139.289 \\
\hline 358 & 1 & & & & & & & & & & & & & $260+50$ & 20 & 4132.468 & 8139.288 \\
\hline 359 & & & 1 & & & & & & & & & & & $260+35$ & 5 & 4132.466 & 8139.289 \\
\hline 360 & & & 1 & & & & & & & & & & & $260+35$ & 5 & 4132.466 & 8139.289 \\
\hline 361 & 1 & & & & & & & & & & & & & $260+40$ & 20 & 4132.468 & 8139.290 \\
\hline 362 & 1 & & & & & & & & & & & & & $260+45$ & 20 & 4132.468 & 8139.291 \\
\hline 363 & 1 & & & & & & & & & & & & & $260+35$ & 20 & 4132.467 & 8139.292 \\
\hline 364 & & & 1 & & & & & & & & & & & $260+35$ & 25 & 4132.467 & 8139.291 \\
\hline 365 & & & 1 & & & & & & & & & & & $260+30$ & 15 & 4132.467 & 8139.295 \\
\hline 366 & 1 & & & & & & & 1 & & & & & & $260+35$ & 38 & & \\
\hline 367 & 1 & & & & & & & & & & & & & $260+10$ & 38 & 4132.466 & 8139.296 \\
\hline
\end{tabular}




\begin{tabular}{|c|c|c|c|c|c|c|c|c|c|c|c|c|c|c|c|c|c|}
\hline \multirow[t]{2}{*}{$\begin{array}{l}\text { Dolos } \\
\text { Number }\end{array}$} & \multicolumn{13}{|c|}{ Break Type } & \multicolumn{4}{|c|}{ Location } \\
\hline & $\begin{array}{l}\text { Straight } \\
\text { Shank }\end{array}$ & $\begin{array}{l}\text { Straight } \\
\text { Mid } \\
\text { Shank }\end{array}$ & $\begin{array}{l}\text { Angled } \\
\text { Shank }\end{array}$ & $\begin{array}{l}\text { Angled } \\
\text { Mid } \\
\text { Shank }\end{array}$ & $\begin{array}{l}\text { Cracked } \\
\text { Shank }\end{array}$ & $\begin{array}{l}\text { Straight } \\
\text { Fluke }\end{array}$ & $\begin{array}{l}\text { Straight } \\
\text { Fluke } \\
\text { Tip }\end{array}$ & $\begin{array}{l}\text { Angled } \\
\text { Fluke }\end{array}$ & $\begin{array}{l}\text { Angled } \\
\text { Fluke } \\
\text { Tip }\end{array}$ & $\begin{array}{l}\text { Cracked } \\
\text { Fluke }\end{array}$ & $\begin{array}{l}\text { Damaged } \\
\text { Fluke }\end{array}$ & $\begin{array}{c}\text { Damaged/ } \\
\text { Broken } \\
\text { Fluke Tip }\end{array}$ & Pieces & $\begin{array}{l}\text { Station } \\
\text { Number }\end{array}$ & $\begin{array}{c}\text { Distance } \\
\text { from } \\
\text { Baseline }\end{array}$ & $\begin{array}{c}\text { GPS North } \\
\text { (Decimal } \\
\text { degrees) }\end{array}$ & $\begin{array}{l}\text { GPS 38st } \\
\text { (Decimal } \\
\text { degrees) }\end{array}$ \\
\hline 368 & & & 1 & & & & & & & & & & & $259+95$ & 5 & 4132.462 & 8139.300 \\
\hline 369 & 1 & & & & & & & & & & & & & $259+85$ & 25 & 4132.463 & 8139.301 \\
\hline 370 & & & 1 & & & & & & & & & & & $259+75$ & 15 & 4132.462 & 8139.300 \\
\hline 371 & & & 1 & & & & & & & & & & & $259+75$ & 10 & 4132.461 & 8139.301 \\
\hline 372 & & & & & & & & 1 & & & & & & $259+75$ & 20 & 4132.463 & 8139.302 \\
\hline 373 & & & & & & 1 & & & & & & & & $259+75$ & 20 & 4132.462 & 8139.302 \\
\hline 374 & 1 & & & & & & & & & & & & & $259+55$ & 10 & 4132.459 & 8139.306 \\
\hline 375 & & & 1 & & & & & & & & & & & $259+55$ & 25 & 4132.460 & 8139.307 \\
\hline 376 & & & 1 & & & & & & & & & & & $259+40$ & 30 & 4132.460 & 8139.307 \\
\hline 377 & 1 & & & & & & & & & & & & & $259+40$ & 30 & 4132.459 & 8139.308 \\
\hline 378 & 1 & & & & & & & & & & & & & $259+40$ & 25 & 4132.460 & 8139.308 \\
\hline 379 & & & & & & & & 1 & & & & & & $259+40$ & 38 & 4132.460 & 8139.309 \\
\hline 380 & & & 1 & & & & & & & & & & & $259+40$ & 10 & & \\
\hline 381 & 1 & & & & & & & & & & & & & $259+40$ & 25 & 4132.459 & 8139.310 \\
\hline 382 & & & & & & & & 1 & & & & & & $259+30$ & 20 & 4132.457 & 8139.311 \\
\hline 383 & & & 1 & & & & & & & & & & & $259+20$ & 10 & 4132.456 & 8139.311 \\
\hline 384 & & & 1 & & & & & 1 & & & & & & $259+20$ & 20 & 4132.456 & 8139.313 \\
\hline 385 & & & 1 & & & & & & & & & & & $259+20$ & 20 & 4132.455 & 8139.313 \\
\hline 386 & & & & & & & & & & & & 1 & & $259+30$ & 10 & 4132.452 & 8139.310 \\
\hline 387 & & & 1 & & & & & & & & & & & $259+20$ & 25 & 4132.456 & 8139.313 \\
\hline 388 & 1 & & & & & & & & & & & & & $259+20$ & 25 & 4132.455 & 8139.312 \\
\hline 389 & & & 1 & & & & & & & & & & & $259+20$ & 25 & & \\
\hline 390 & 1 & & & & & & & 1 & & & & & & $259+20$ & 20 & 4132.455 & 8139.314 \\
\hline
\end{tabular}




\begin{tabular}{|c|c|c|c|c|c|c|c|c|c|c|c|c|c|c|c|c|c|}
\hline \multirow[t]{2}{*}{$\begin{array}{c}\text { Dolos } \\
\text { Number }\end{array}$} & \multicolumn{13}{|c|}{ Break Type } & \multicolumn{4}{|c|}{ Location } \\
\hline & $\begin{array}{l}\text { Straight } \\
\text { Shank }\end{array}$ & $\begin{array}{l}\text { Straight } \\
\text { Mid } \\
\text { Shank }\end{array}$ & $\begin{array}{l}\text { Angled } \\
\text { Shank }\end{array}$ & $\begin{array}{c}\text { Angled } \\
\text { Mid } \\
\text { Shank }\end{array}$ & $\begin{array}{l}\text { Cracked } \\
\text { Shank }\end{array}$ & $\begin{array}{l}\text { Straight } \\
\text { Fluke }\end{array}$ & $\begin{array}{l}\text { Straight } \\
\text { Fluke } \\
\text { Tip }\end{array}$ & $\begin{array}{l}\text { Angled } \\
\text { Fluke }\end{array}$ & $\begin{array}{c}\text { Angled } \\
\text { Fluke } \\
\text { Tip }\end{array}$ & $\begin{array}{c}\text { Cracked } \\
\text { Fluke }\end{array}$ & $\begin{array}{l}\text { Damaged } \\
\text { Fluke }\end{array}$ & $\begin{array}{c}\text { Damaged/ } \\
\text { Broken } \\
\text { Fluke Tip }\end{array}$ & Pieces & $\begin{array}{l}\text { Station } \\
\text { Number }\end{array}$ & $\begin{array}{l}\text { Distance } \\
\text { from } \\
\text { Baseline }\end{array}$ & $\begin{array}{l}\text { GPS North } \\
\text { (Decimal } \\
\text { degrees) }\end{array}$ & $\begin{array}{l}\text { GPS 38st } \\
\text { (Decimal } \\
\text { degrees) }\end{array}$ \\
\hline 391 & 1 & & & & & & & & & & & & & $258+85$ & 15 & 4132.454 & 8139.315 \\
\hline 392 & & & & & & & & 1 & & & & & & $258+85$ & 15 & 4132.454 & 8139.315 \\
\hline 393 & 1 & & & & & & & 1 & & & & & & $258+95$ & 20 & 4132.454 & 8139.316 \\
\hline 394 & 1 & & & & & & & & & & & & & $258+95$ & 25 & & \\
\hline 395 & & & 1 & & & & & & & & & & & $258+85$ & 15 & 4132.453 & 8139.316 \\
\hline 396 & & & 1 & & & & & & & & & & & $258+85$ & 15 & 4132.454 & 8139.316 \\
\hline 397 & & & 1 & & & & & & & & & & & $268+75$ & 38 & 4132.454 & 8139.317 \\
\hline 398 & & & & & & & & 1 & & & & & & $258+85$ & 38 & 4132.455 & 8139.315 \\
\hline 399 & 1 & & & & & & & & & & & & & $268+75$ & 38 & 4132.454 & 8139.318 \\
\hline 400 & & & 1 & & & & & & & & & & & $258+70$ & 10 & 4132.450 & 8139.317 \\
\hline 401 & & & & & & & & 2 & & & & & & $258+60$ & 10 & 4132.449 & 8139.319 \\
\hline 402 & & & 1 & & & & & & & & & & & $258+70$ & 20 & 4132.453 & 8139.319 \\
\hline 403 & & 1 & & & & & & & & & & & & $258+70$ & 38 & 4132.451 & 8139.320 \\
\hline 404 & & & & & & 1 & & & & & & & & $258+50$ & 38 & 4132.451 & 8139.323 \\
\hline 405 & & & & & & & & & & & & 1 & & $258+60$ & 38 & 4132.451 & 8139.323 \\
\hline 406 & 1 & & & & & & & & & & & & & $258+50$ & 20 & 4132.450 & 8139.322 \\
\hline 407 & & & & & & & & 2 & & & & & & $258+60$ & 20 & 4132.450 & 8139.322 \\
\hline 408 & & & 1 & & & & & & & & & & & $258+50$ & 25 & 4132.450 & 8139.321 \\
\hline 409 & 1 & & & & & 1 & & & & & & & & $258+50$ & 20 & 4132.450 & 8139.322 \\
\hline 410 & 1 & & & & & & & & & & & & & $258+45$ & 20 & 4132.450 & 8139.323 \\
\hline 411 & & & & & & & & 1 & & & & & & $258+45$ & 15 & 4132.449 & 8139.323 \\
\hline 412 & & & 1 & & & & & & & & & & & $258+25$ & 5 & 4132.447 & 8139.326 \\
\hline 413 & 1 & & & & & & & & & & & & & $258+30$ & 15 & 4132.448 & 8139.326 \\
\hline
\end{tabular}




\begin{tabular}{|c|c|c|c|c|c|c|c|c|c|c|c|c|c|c|c|c|c|}
\hline \multirow[t]{2}{*}{$\begin{array}{c}\text { Dolos } \\
\text { Number }\end{array}$} & \multicolumn{13}{|c|}{ Break Type } & \multicolumn{4}{|c|}{ Location } \\
\hline & $\begin{array}{l}\text { Straight } \\
\text { Shank }\end{array}$ & $\begin{array}{l}\text { Straight } \\
\text { Mid } \\
\text { Shank }\end{array}$ & $\begin{array}{l}\text { Angled } \\
\text { Shank }\end{array}$ & $\begin{array}{c}\text { Angled } \\
\text { Mid } \\
\text { Shank }\end{array}$ & $\begin{array}{l}\text { Cracked } \\
\text { Shank }\end{array}$ & $\begin{array}{l}\text { Straight } \\
\text { Fluke }\end{array}$ & $\begin{array}{l}\text { Straight } \\
\text { Fluke } \\
\text { Tip }\end{array}$ & $\begin{array}{l}\text { Angled } \\
\text { Fluke }\end{array}$ & $\begin{array}{c}\text { Angled } \\
\text { Fluke } \\
\text { Tip }\end{array}$ & $\begin{array}{c}\text { Cracked } \\
\text { Fluke }\end{array}$ & $\begin{array}{l}\text { Damaged } \\
\text { Fluke }\end{array}$ & $\begin{array}{c}\text { Damaged/ } \\
\text { Broken } \\
\text { Fluke Tip }\end{array}$ & Pieces & $\begin{array}{l}\text { Station } \\
\text { Number }\end{array}$ & $\begin{array}{l}\text { Distance } \\
\text { from } \\
\text { Baseline }\end{array}$ & $\begin{array}{l}\text { GPS North } \\
\text { (Decimal } \\
\text { degrees) }\end{array}$ & $\begin{array}{l}\text { GPS 38st } \\
\text { (Decimal } \\
\text { degrees) }\end{array}$ \\
\hline 414 & 1 & & & & & & & & & & & & & $258+30$ & 38 & 4132.448 & 8139.326 \\
\hline 415 & 1 & & & & & & & & & & & & & $258+30$ & 38 & 4132.448 & 8139.325 \\
\hline 416 & 1 & & & & & & & & & & & & & $258+30$ & 38 & 4132.448 & 8139.325 \\
\hline 417 & 1 & & & & & & & & & & & & & $258+00$ & 15 & 4132.445 & 8139.333 \\
\hline 418 & & & & & & & & 1 & & & & & & $258+00$ & 15 & 4132.444 & 8139.333 \\
\hline 419 & & & & & & 1 & & & & & & & & $258+00$ & 25 & 4132.445 & 8139.333 \\
\hline 420 & & & & & & & & 1 & & & & & & $258+00$ & 20 & 4132.445 & 8139.333 \\
\hline 421 & & & 1 & & & & & & & & & & & $257+75$ & 10 & 4132.442 & 8139.336 \\
\hline 422 & 1 & & & & & & & & & & & & & $257+75$ & 15 & 4132.442 & 8139.336 \\
\hline 423 & & & & & & 1 & & & & & & & & $257+75$ & 15 & 4132.442 & 8139.336 \\
\hline 424 & 1 & & & & & & & & & & & & & $257+75$ & 38 & 4132.443 & 8139.335 \\
\hline 425 & 1 & & & & & & & & & & & & & $257+75$ & 20 & 4132.443 & 8139.335 \\
\hline 426 & & & & & & & & 1 & & & & & & $257+75$ & 20 & 4132.442 & 8139.335 \\
\hline 427 & & & & & & & & 1 & & & & & & $257+60$ & 15 & 4132.440 & 8139.339 \\
\hline 428 & 1 & & & & & & & & & & & & & $257+40$ & 25 & 4132.441 & 8139.340 \\
\hline 429 & 1 & & & & & & & 1 & & & & & & $257+40$ & 25 & 4132.442 & 8139.340 \\
\hline 430 & & & & & & 1 & & & & & & & & $257+40$ & 20 & & \\
\hline 431 & & & 1 & & & & & & & & & & & $257+40$ & 15 & 4132.441 & 8139.340 \\
\hline 432 & & & & & & & & 2 & & & & & & $257+40$ & 25 & 4132.440 & 8139.341 \\
\hline 433 & & & 1 & & & & & & & & & 1 & & $257+20$ & 20 & 4132.438 & 8139.347 \\
\hline 434 & & 1 & & & & & & & & & & & & $257+10$ & 38 & 4132.437 & 8139.347 \\
\hline 435 & & & 1 & & & & & & & & & & & $257+00$ & 30 & 4132.435 & 8139.351 \\
\hline 436 & 1 & & & & & & & & & & & & & $256+85$ & 20 & 4132.434 & 8139.352 \\
\hline
\end{tabular}




\begin{tabular}{|c|c|c|c|c|c|c|c|c|c|c|c|c|c|c|c|c|c|}
\hline \multirow[t]{2}{*}{$\begin{array}{l}\text { Dolos } \\
\text { Number }\end{array}$} & \multicolumn{13}{|c|}{ Break Type } & \multicolumn{4}{|c|}{ Location } \\
\hline & $\begin{array}{l}\text { Straight } \\
\text { Shank }\end{array}$ & $\begin{array}{l}\text { Straight } \\
\text { Mid } \\
\text { Shank }\end{array}$ & $\begin{array}{l}\text { Angled } \\
\text { Shank }\end{array}$ & $\begin{array}{c}\text { Angled } \\
\text { Mid } \\
\text { Shank }\end{array}$ & $\begin{array}{l}\text { Cracked } \\
\text { Shank }\end{array}$ & $\begin{array}{l}\text { Straight } \\
\text { Fluke }\end{array}$ & $\begin{array}{l}\text { Straight } \\
\text { Fluke } \\
\text { Tip }\end{array}$ & $\begin{array}{l}\text { Angled } \\
\text { Fluke }\end{array}$ & $\begin{array}{c}\text { Angled } \\
\text { Fluke } \\
\text { Tip }\end{array}$ & $\begin{array}{l}\text { Cracked } \\
\text { Fluke }\end{array}$ & $\begin{array}{l}\text { Damaged } \\
\text { Fluke }\end{array}$ & $\begin{array}{l}\text { Damaged/ } \\
\text { Broken } \\
\text { Fluke Tip }\end{array}$ & Pieces & $\begin{array}{l}\text { Station } \\
\text { Number }\end{array}$ & $\begin{array}{l}\text { Distance } \\
\text { from } \\
\text { Baseline }\end{array}$ & $\begin{array}{l}\text { GPS North } \\
\text { (Decimal } \\
\text { degrees) }\end{array}$ & $\begin{array}{l}\text { GPS 38st } \\
\text { (Decimal } \\
\text { degrees) }\end{array}$ \\
\hline 437 & & & 1 & & & & & & & & & & & $256+60$ & 0 & 4132.430 & 8139.352 \\
\hline 438 & & & & 1 & & & & & & & & & & $256+60$ & 10 & 4132.431 & 8139.353 \\
\hline 439 & & & 1 & & & & & & & & & & & $256+60$ & 15 & 4132.431 & 8139.353 \\
\hline 440 & & & 1 & & & & & 1 & & & & & & $256+60$ & 10 & 4132.431 & 8139.354 \\
\hline 441 & & & & & & & & 1 & & & & & & $256+60$ & 10 & 4132.431 & 8139.357 \\
\hline 442 & & & & & & & & 1 & & & & & & $256+60$ & 15 & 4132.431 & 8139.357 \\
\hline 443 & 1 & & & & & & & & & & & & & $256+60$ & 20 & 4132.431 & 8139.357 \\
\hline 444 & & & & & & 1 & & & & & & & & $256+50$ & 20 & 4132.431 & 8139.358 \\
\hline 445 & 1 & & & & & & & & & & & & & $256+90$ & 20 & 4132.432 & 8139.355 \\
\hline 446 & & & 1 & & & & & & & & & & & $256+60$ & 20 & & \\
\hline 447 & 1 & & & & & & & & & & & & & $256+60$ & 20 & 4132.431 & 8139.358 \\
\hline 448 & 1 & & & & & & & & & & & & & $256+60$ & 25 & 4132.432 & 8139.357 \\
\hline 449 & & & & & & & & & & & & & 1 & $256+60$ & 38 & & \\
\hline 450 & & & & & & & & 1 & & & & & & $256+45$ & 20 & 4132.430 & 8139.359 \\
\hline 451 & & & 1 & & & & & & & & & & & $256+45$ & 25 & 4132.431 & 8139.359 \\
\hline 452 & 1 & & & & & & & & & & & & & $256+35$ & 15 & 4132.429 & 8139.359 \\
\hline 453 & 1 & & & & & & & & & & & & & $256+20$ & 25 & 4132.429 & 8139.362 \\
\hline 454 & & & 1 & & & & & & & & & & & $256+20$ & 38 & 4132.429 & 8139.364 \\
\hline 455 & 1 & & & & & & & & & & & & & $256+20$ & 15 & 4132.427 & 8139.364 \\
\hline 456 & & & 1 & & & & & & & & & & & $256+10$ & 25 & 4132.427 & 8139.366 \\
\hline 457 & & & 1 & & & & & 1 & & & & & & $255+90$ & 25 & 4132.426 & 8139.366 \\
\hline 458 & 1 & & & & & & & & & & & & & $255+90$ & 25 & 4132.426 & 8139.367 \\
\hline 459 & & & & & & & & & & 1 & & & & $255+80$ & 15 & 4132.423 & 8139.370 \\
\hline
\end{tabular}




\begin{tabular}{|c|c|c|c|c|c|c|c|c|c|c|c|c|c|c|c|c|c|}
\hline \multirow[t]{2}{*}{$\begin{array}{l}\text { Dolos } \\
\text { Number }\end{array}$} & \multicolumn{13}{|c|}{ Break Type } & \multicolumn{4}{|c|}{ Location } \\
\hline & $\begin{array}{l}\text { Straight } \\
\text { Shank }\end{array}$ & $\begin{array}{l}\text { Straight } \\
\text { Mid } \\
\text { Shank }\end{array}$ & $\begin{array}{l}\text { Angled } \\
\text { Shank }\end{array}$ & $\begin{array}{l}\text { Angled } \\
\text { Mid } \\
\text { Shank }\end{array}$ & $\begin{array}{l}\text { Cracked } \\
\text { Shank }\end{array}$ & $\begin{array}{l}\text { Straight } \\
\text { Fluke }\end{array}$ & $\begin{array}{l}\text { Straight } \\
\text { Fluke } \\
\text { Tip }\end{array}$ & $\begin{array}{l}\text { Angled } \\
\text { Fluke }\end{array}$ & $\begin{array}{l}\text { Angled } \\
\text { Fluke } \\
\text { Tip }\end{array}$ & $\begin{array}{l}\text { Cracked } \\
\text { Fluke }\end{array}$ & $\begin{array}{l}\text { Damaged } \\
\text { Fluke }\end{array}$ & $\begin{array}{l}\text { Damaged/ } \\
\text { Broken } \\
\text { Fluke Tip }\end{array}$ & Pieces & $\begin{array}{l}\text { Station } \\
\text { Number }\end{array}$ & $\begin{array}{l}\text { Distance } \\
\text { from } \\
\text { Baseline }\end{array}$ & $\begin{array}{l}\text { GPS North } \\
\text { (Decimal } \\
\text { degrees) }\end{array}$ & $\begin{array}{l}\text { GPS 38st } \\
\text { (Decimal } \\
\text { degrees) }\end{array}$ \\
\hline 460 & & & & 1 & & & & & & & & & & $255+90$ & 25 & 4132.426 & 8139.368 \\
\hline 461 & & & 1 & & & & & & & & & & & $255+65$ & 15 & 4132.424 & 8139.371 \\
\hline 462 & & & 1 & & & & & & & & & & & $255+90$ & 25 & & \\
\hline 463 & & & & & & & & 2 & & & & & & $255+65$ & 10 & 4132.423 & 8139.371 \\
\hline 464 & 1 & & & & 1 & 1 & & & & & & & & $255+65$ & 25 & 4132.424 & 8139.372 \\
\hline 465 & 1 & & & & & & & & & & & & & $255+40$ & 15 & 4132.421 & 8139.374 \\
\hline 466 & & & & & & 1 & & & & & & & & $255+55$ & 38 & & \\
\hline 467 & 1 & & & & & & & & & & & & & $255+40$ & 15 & 4132.420 & 8139.377 \\
\hline 468 & & & & & & & & 1 & & & & & & $255+40$ & 10 & 4132.421 & 8139.376 \\
\hline 469 & & & 1 & & & & & & & & & & & $255+40$ & 25 & 4132.420 & 8139.377 \\
\hline 470 & & & 1 & & & 1 & & & & & & & & $255+40$ & 25 & 4132.420 & 8139.378 \\
\hline 471 & 1 & & & & & & & & & & & & & $255+40$ & 38 & 4132.420 & 8139.378 \\
\hline 472 & 1 & & & & & & & & & & & & & $255+40$ & 25 & 4132.420 & 8139.378 \\
\hline 473 & & & & & & & & 1 & & & & & & $255+40$ & 20 & 4132.420 & 8139.377 \\
\hline 474 & 1 & & & & & & & & & & & & & $255+30$ & 15 & 4132.418 & 8139.378 \\
\hline 475 & & & 1 & & & & & & & & & & & $255+40$ & 25 & 4132.419 & 8139.379 \\
\hline 476 & 1 & & & & & & & & & & & & & $255+40$ & 30 & 4132.417 & 8139.372 \\
\hline 477 & & & 1 & & & & & & & & & & & $255+10$ & 10 & 4132.417 & 8139.377 \\
\hline 478 & & & & 1 & & & & & & & & & & $255+25$ & 25 & 4132.417 & 8139.385 \\
\hline 479 & 1 & & & & & & & & & & & & & $255+25$ & 25 & 4132.414 & 8139.387 \\
\hline 480 & & & & & & 1 & & & & & & & & $255+10$ & 38 & 4132.417 & 8139.387 \\
\hline 481 & & & 1 & & & & & 1 & & & & & & $254+80$ & 15 & 4132.413 & 8139.388 \\
\hline 482 & 1 & & & & & & & & & & & & & $254+75$ & 20 & 4132.412 & 8139.388 \\
\hline
\end{tabular}




\begin{tabular}{|c|c|c|c|c|c|c|c|c|c|c|c|c|c|c|c|c|c|}
\hline \multirow[t]{2}{*}{$\begin{array}{l}\text { Dolos } \\
\text { Number }\end{array}$} & \multicolumn{13}{|c|}{ Break Type } & \multicolumn{4}{|c|}{ Location } \\
\hline & $\begin{array}{l}\text { Straight } \\
\text { Shank }\end{array}$ & $\begin{array}{l}\text { Straight } \\
\text { Mid } \\
\text { Shank }\end{array}$ & $\begin{array}{l}\text { Angled } \\
\text { Shank }\end{array}$ & $\begin{array}{l}\text { Angled } \\
\text { Mid } \\
\text { Shank }\end{array}$ & $\begin{array}{l}\text { Cracked } \\
\text { Shank }\end{array}$ & $\begin{array}{l}\text { Straight } \\
\text { Fluke }\end{array}$ & $\begin{array}{c}\text { Straight } \\
\text { Fluke } \\
\text { Tip }\end{array}$ & $\begin{array}{l}\text { Angled } \\
\text { Fluke }\end{array}$ & $\begin{array}{l}\text { Angled } \\
\text { Fluke } \\
\text { Tip }\end{array}$ & $\begin{array}{l}\text { Cracked } \\
\text { Fluke }\end{array}$ & $\begin{array}{c}\text { Damaged } \\
\text { Fluke }\end{array}$ & $\begin{array}{c}\text { Damaged/ } \\
\text { Broken } \\
\text { Fluke Tip }\end{array}$ & Pieces & $\begin{array}{l}\text { Station } \\
\text { Number }\end{array}$ & $\begin{array}{c}\text { Distance } \\
\text { from } \\
\text { Baseline }\end{array}$ & $\begin{array}{c}\text { GPS North } \\
\text { (Decimal } \\
\text { degrees) }\end{array}$ & $\begin{array}{l}\text { GPS 38st } \\
\text { (Decimal } \\
\text { degrees) }\end{array}$ \\
\hline 483 & & 1 & & & & & & & & & & & & $254+65$ & 25 & 4132.413 & 8139.389 \\
\hline 484 & & & 1 & & & & & & & & & & & $254+60$ & 20 & 4132.411 & 8139.390 \\
\hline 485 & 1 & & & & & 1 & & & & & & & & $254+75$ & 25 & 4132.413 & 8139.388 \\
\hline 486 & & & & & & & & 1 & & & & & & $254+55$ & 20 & 4132.410 & 8139.392 \\
\hline 487 & 1 & & & & & & & & & & & & & $254+50$ & 0 & 4132.408 & 8139.393 \\
\hline 488 & 1 & & & & & & & & & & & & & $254+45$ & 20 & 4132.410 & 8139.393 \\
\hline 489 & & & & 1 & & & & & & & & & & $254+55$ & 25 & 4132.411 & 8139.393 \\
\hline 490 & & & & & & & & 1 & & & & & & $254+45$ & 25 & 4132.411 & 8139.395 \\
\hline 491 & & & 1 & & & & & & & & & & & $254+45$ & 38 & & \\
\hline 492 & & & & & & 1 & & & & & & & & $254+35$ & 15 & 4132.408 & 8139.395 \\
\hline 493 & & & 1 & & & & & & & & & & & $254+35$ & 20 & 4132.408 & 8139.396 \\
\hline 494 & & & & & & & & 2 & & & & & & $254+25$ & 20 & 4132.408 & 8139.397 \\
\hline 495 & & & & & & & & 1 & & & & & & $254+25$ & 25 & 4132.409 & 8139.398 \\
\hline 496 & & & 1 & & & & & & & & & & & $254+25$ & 10 & & \\
\hline 497 & & & 1 & & & & & 1 & & & & & & $254+20$ & 20 & 4132.407 & 8139.398 \\
\hline 498 & 1 & & & & & & & & & & & & & $254+20$ & 15 & 4132.406 & 8139.397 \\
\hline 499 & 1 & & & & & & & 1 & & & & & & $254+20$ & 20 & 4132.408 & 8139.399 \\
\hline 500 & 1 & & & & & & & & & & & & & $254+20$ & 20 & 4132.408 & 8139.399 \\
\hline 501 & & & & & & & & 1 & & & & & & $254+15$ & 15 & 4132.406 & 8139.399 \\
\hline 502 & 1 & & & & & & & & & & & & & $254+20$ & 15 & 4132.406 & 8139.398 \\
\hline 503 & & & 1 & & & & & & & & & & & $254+15$ & 20 & 4132.406 & 8139.399 \\
\hline 504 & & & & & & & & 2 & & & & & & $254+10$ & 20 & 4132.406 & 8139.399 \\
\hline 505 & 1 & & & & & & & 1 & & & & & & $254+05$ & 15 & 4132.406 & 8139.401 \\
\hline
\end{tabular}




\begin{tabular}{|c|c|c|c|c|c|c|c|c|c|c|c|c|c|c|c|c|c|}
\hline \multirow[t]{2}{*}{$\begin{array}{l}\text { Dolos } \\
\text { Number }\end{array}$} & \multicolumn{13}{|c|}{ Break Type } & \multicolumn{4}{|c|}{ Location } \\
\hline & $\begin{array}{l}\text { Straight } \\
\text { Shank }\end{array}$ & $\begin{array}{l}\text { Straight } \\
\text { Mid } \\
\text { Shank }\end{array}$ & $\begin{array}{l}\text { Angled } \\
\text { Shank }\end{array}$ & $\begin{array}{l}\text { Angled } \\
\text { Mid } \\
\text { Shank }\end{array}$ & $\begin{array}{l}\text { Cracked } \\
\text { Shank }\end{array}$ & $\begin{array}{l}\text { Straight } \\
\text { Fluke }\end{array}$ & $\begin{array}{l}\text { Straight } \\
\text { Fluke } \\
\text { Tip }\end{array}$ & $\begin{array}{l}\text { Angled } \\
\text { Fluke }\end{array}$ & $\begin{array}{l}\text { Angled } \\
\text { Fluke } \\
\text { Tip }\end{array}$ & $\begin{array}{l}\text { Cracked } \\
\text { Fluke }\end{array}$ & $\begin{array}{l}\text { Damaged } \\
\text { Fluke }\end{array}$ & $\begin{array}{c}\text { Damaged/ } \\
\text { Broken } \\
\text { Fluke Tip }\end{array}$ & Pieces & $\begin{array}{l}\text { Station } \\
\text { Number }\end{array}$ & $\begin{array}{c}\text { Distance } \\
\text { from } \\
\text { Baseline }\end{array}$ & $\begin{array}{c}\text { GPS North } \\
\text { (Decimal } \\
\text { degrees) }\end{array}$ & $\begin{array}{l}\text { GPS 38st } \\
\text { (Decimal } \\
\text { degrees) }\end{array}$ \\
\hline 506 & & & & & & & & 2 & & & & & & $254+05$ & 20 & 4132.406 & 8139.402 \\
\hline 507 & 1 & & & & & & & & & & & & & $253+90$ & 15 & 4132.403 & 8139.403 \\
\hline 508 & & & 1 & & & & & & & & & & & $254+15$ & 38 & 4132.407 & 8139.402 \\
\hline 509 & & & & & & & & 1 & & & & & & $254+10$ & 38 & 4132.407 & 8139.401 \\
\hline 510 & & & & & & 1 & & & & & & & & $253+90$ & 15 & 4132.403 & 8139.403 \\
\hline 511 & 1 & & & & & & & & & & & & & $253+90$ & 20 & 4132.404 & 8139.404 \\
\hline 512 & & & & & & & & 2 & & & & & & $254+15$ & 25 & & \\
\hline 513 & & & & 1 & & & & & & & & & & $253+80$ & 20 & 4132.405 & 8139.405 \\
\hline 514 & 1 & & & & & & & & & & & & & $253+80$ & 15 & 4132.403 & 8139.405 \\
\hline 515 & 1 & & & & & & & & & & & & & $253+90$ & 25 & 4132.405 & 8139.404 \\
\hline 516 & & & & & & & & 1 & & & & & & $253+90$ & 20 & 4132.404 & 8139.404 \\
\hline 517 & & & & & & & & & & & & & 1 & $253+80$ & 25 & 4132.404 & 8139.406 \\
\hline 518 & & & & & & & & 1 & & & & & & $253+70$ & 25 & 4132.403 & 8139.409 \\
\hline 519 & & & & & & & & & & & & & 1 & $253+60$ & 38 & 4132.403 & 8139.410 \\
\hline 520 & & & & & & 1 & & & & & & & & $253+60$ & 25 & 4132.402 & 8139.409 \\
\hline 521 & & & 1 & & & & & & & & & & & $253+60$ & 15 & 4132.401 & 8139.409 \\
\hline 522 & & & 1 & & & & & & & & & & & $253+50$ & 20 & 4132.401 & 8139.410 \\
\hline 523 & 1 & & & & & & & & & & & & & $253+55$ & 10 & 4132.400 & 8139.409 \\
\hline 524 & & & & & & & & 1 & & & & & & $253+40$ & 10 & 4132.399 & 8139.412 \\
\hline 525 & 1 & & & & & & & & & & & & & $253+40$ & 15 & 4132.399 & 8139.412 \\
\hline 526 & 1 & & & & & & & & & & & & & $253+30$ & 10 & 4132.397 & 8139.415 \\
\hline 527 & & & & & & & & 1 & & & & & & $253+30$ & 15 & 4132.398 & 8139.416 \\
\hline 528 & 1 & & & & & & & & & & & & & $253+30$ & 25 & 4132.398 & 8139.415 \\
\hline
\end{tabular}




\begin{tabular}{|c|c|c|c|c|c|c|c|c|c|c|c|c|c|c|c|c|c|}
\hline \multirow[t]{2}{*}{$\begin{array}{l}\text { Dolos } \\
\text { Number }\end{array}$} & \multicolumn{13}{|c|}{ Break Type } & \multicolumn{4}{|c|}{ Location } \\
\hline & $\begin{array}{l}\text { Straight } \\
\text { Shank }\end{array}$ & $\begin{array}{l}\text { Straight } \\
\text { Mid } \\
\text { Shank }\end{array}$ & $\begin{array}{l}\text { Angled } \\
\text { Shank }\end{array}$ & $\begin{array}{l}\text { Angled } \\
\text { Mid } \\
\text { Shank }\end{array}$ & $\begin{array}{l}\text { Cracked } \\
\text { Shank }\end{array}$ & $\begin{array}{l}\text { Straight } \\
\text { Fluke }\end{array}$ & $\begin{array}{l}\text { Straight } \\
\text { Fluke } \\
\text { Tip }\end{array}$ & $\begin{array}{l}\text { Angled } \\
\text { Fluke }\end{array}$ & $\begin{array}{l}\text { Angled } \\
\text { Fluke } \\
\text { Tip }\end{array}$ & $\begin{array}{l}\text { Cracked } \\
\text { Fluke }\end{array}$ & $\begin{array}{l}\text { Damaged } \\
\text { Fluke }\end{array}$ & $\begin{array}{c}\text { Damaged/ } \\
\text { Broken } \\
\text { Fluke Tip }\end{array}$ & Pieces & $\begin{array}{l}\text { Station } \\
\text { Number }\end{array}$ & $\begin{array}{c}\text { Distance } \\
\text { from } \\
\text { Baseline }\end{array}$ & $\begin{array}{c}\text { GPS North } \\
\text { (Decimal } \\
\text { degrees) }\end{array}$ & $\begin{array}{l}\text { GPS 38st } \\
\text { (Decimal } \\
\text { degrees) }\end{array}$ \\
\hline 529 & & & 1 & & & & & & & & & & & $253+05$ & 5 & 4132.394 & 8139.418 \\
\hline 530 & & & & & & & & 1 & & & & & & $253+00$ & 10 & 4132.395 & 8139.419 \\
\hline 531 & 1 & & & & & & & & & & & & & $253+05$ & 15 & 4132.395 & 8139.419 \\
\hline 532 & 1 & & & & & & & & & & & & & $253+05$ & 25 & 4132.395 & 8139.419 \\
\hline 533 & & & 1 & & & & & & & & & & & $252+95$ & 25 & 4132.396 & 8139.420 \\
\hline 534 & & & 1 & & & & & & & & & & & $252+90$ & 25 & 4132.396 & 8139.421 \\
\hline 535 & & & & & & & & & & 1 & & & & $252+95$ & 30 & 4132.397 & 8139.421 \\
\hline 536 & 1 & & & & & & & & & & & & & $252+90$ & 30 & 4132.396 & 8139.421 \\
\hline 537 & & & 1 & & & & & & & & & & & $252+90$ & 15 & 4132.393 & 8139.421 \\
\hline 538 & & & 1 & & & & & & & & & & & $252+75$ & 15 & 4132.393 & 8139.421 \\
\hline 539 & & & 1 & & & & & & & & & & & $252+90$ & 25 & 4132.395 & 8139.422 \\
\hline 540 & & & & & & & & 1 & & & & & & $252+70$ & 20 & 4132.394 & 8139.424 \\
\hline 541 & & & & & & & & 1 & & & & & & $252+75$ & 38 & & \\
\hline 542 & & & 1 & & & & & & & & & & & $252+70$ & 20 & 4132.393 & 8139.425 \\
\hline 543 & 1 & & & & & & & & & & & & & $252+60$ & 25 & 4132.392 & 8139.427 \\
\hline 544 & & & & & & & & 1 & & & & & & $252+95$ & 38 & 4132.395 & 8139.422 \\
\hline 545 & & & & & & & & 1 & & & & & & $252+50$ & 20 & 4132.391 & 8139.428 \\
\hline 546 & 1 & & & & & & & & & & & & & $252+30$ & 5 & 4132.388 & 8139.430 \\
\hline 547 & & & 1 & & & & & & & & & & & $252+30$ & 10 & 4132.388 & 8139.431 \\
\hline 548 & & & 1 & & & & & & & & & & & $252+20$ & 15 & 4132.388 & 8139.433 \\
\hline 549 & & & & & & & & 1 & & & & & & $252+20$ & 25 & 4132.388 & 8139.433 \\
\hline 550 & & & & & & & & 1 & & & & & & $252+00$ & 15 & 4132.386 & 8139.435 \\
\hline 551 & & & & & & & & & & & & & 1 & $252+10$ & 38 & 4132.388 & 8139.434 \\
\hline
\end{tabular}




\begin{tabular}{|c|c|c|c|c|c|c|c|c|c|c|c|c|c|c|c|c|c|}
\hline \multirow[t]{2}{*}{$\begin{array}{c}\text { Dolos } \\
\text { Number }\end{array}$} & \multicolumn{13}{|c|}{ Break Type } & \multicolumn{4}{|c|}{ Location } \\
\hline & $\begin{array}{l}\text { Straight } \\
\text { Shank }\end{array}$ & $\begin{array}{l}\text { Straight } \\
\text { Mid } \\
\text { Shank }\end{array}$ & $\begin{array}{l}\text { Angled } \\
\text { Shank }\end{array}$ & $\begin{array}{c}\text { Angled } \\
\text { Mid } \\
\text { Shank }\end{array}$ & $\begin{array}{l}\text { Cracked } \\
\text { Shank }\end{array}$ & $\begin{array}{l}\text { Straight } \\
\text { Fluke }\end{array}$ & $\begin{array}{l}\text { Straight } \\
\text { Fluke } \\
\text { Tip }\end{array}$ & $\begin{array}{l}\text { Angled } \\
\text { Fluke }\end{array}$ & $\begin{array}{c}\text { Angled } \\
\text { Fluke } \\
\text { Tip }\end{array}$ & $\begin{array}{c}\text { Cracked } \\
\text { Fluke }\end{array}$ & $\begin{array}{l}\text { Damaged } \\
\text { Fluke }\end{array}$ & $\begin{array}{c}\text { Damaged/ } \\
\text { Broken } \\
\text { Fluke Tip }\end{array}$ & Pieces & $\begin{array}{l}\text { Station } \\
\text { Number }\end{array}$ & $\begin{array}{l}\text { Distance } \\
\text { from } \\
\text { Baseline }\end{array}$ & $\begin{array}{c}\text { GPS North } \\
\text { (Decimal } \\
\text { degrees) }\end{array}$ & $\begin{array}{l}\text { GPS 38st } \\
\text { (Decimal } \\
\text { degrees) }\end{array}$ \\
\hline 552 & & & 1 & & & 1 & & & & & & & & $252+00$ & 10 & 4132.384 & 8139.435 \\
\hline 553 & 1 & & & & & & & & & & & & & $252+10$ & 38 & 4132.387 & 8139.434 \\
\hline 554 & & & & & & & & & & & & & 1 & $252+00$ & 38 & 4132.386 & 8139.436 \\
\hline 555 & & & & & & & & 2 & & & & & & $251+90$ & 38 & 4132.386 & 8139.438 \\
\hline 556 & & & 1 & & & & & & & & & & & $251+80$ & 10 & 4132.383 & 8139.440 \\
\hline 557 & & & 1 & & & & & & & & & & & $251+70$ & 10 & & \\
\hline 558 & & & 1 & & & & & & & & & & & $251+90$ & 25 & 4132.385 & 8139.439 \\
\hline 559 & & & 1 & & & & & & & & & & & $251+70$ & 20 & 4132.382 & 8139.441 \\
\hline 560 & 1 & & & & & & & & & & & & & $251+90$ & 38 & 4132.386 & 8139.439 \\
\hline 561 & & & 1 & & & & & & & & & & & $251+70$ & 20 & 4132.383 & 8139.441 \\
\hline 562 & 1 & & & & & & & & & & & & & $251+90$ & 38 & 4132.385 & 8139.439 \\
\hline 563 & 1 & & & & & & & & & & & & & $251+60$ & 20 & 4132.382 & 8139.442 \\
\hline 564 & & & & 1 & & & & & & & & & & $251+90$ & 38 & 4132.385 & 8139.439 \\
\hline 565 & & & 1 & & & & & & & & & & & $251+60$ & 38 & 4132.382 & 8139.443 \\
\hline 566 & & & & & & 1 & & & & & & & & $251+50$ & 38 & 4132.382 & 8139.442 \\
\hline 567 & 1 & & & & & & & & & & & & & $251+70$ & 20 & 4132.385 & 8139.440 \\
\hline 568 & 1 & & & & & & & & & & & & & $251+60$ & 20 & 4132.381 & 8139.444 \\
\hline 569 & & & & 1 & & & & & & & & & & $251+50$ & 25 & 4132.381 & 8139.444 \\
\hline 570 & & & 1 & & & & & & & & & & & $251+50$ & 20 & 4132.381 & 8139.444 \\
\hline 571 & & & & & & & & 1 & & & & & & $251+40$ & 10 & 4132.379 & 8139.444 \\
\hline 572 & & & 1 & & & 1 & & & & & & & & $251+40$ & 15 & 4132.378 & 8139.445 \\
\hline 573 & 1 & & & & & & & & & & & & & $251+60$ & 38 & & \\
\hline 574 & & & & & & & & & & 1 & & & & $251+40$ & 15 & 4132.380 & 8139.445 \\
\hline
\end{tabular}




\begin{tabular}{|c|c|c|c|c|c|c|c|c|c|c|c|c|c|c|c|c|c|}
\hline \multirow[t]{2}{*}{$\begin{array}{l}\text { Dolos } \\
\text { Number }\end{array}$} & \multicolumn{13}{|c|}{ Break Type } & \multicolumn{4}{|c|}{ Location } \\
\hline & $\begin{array}{l}\text { Straight } \\
\text { Shank }\end{array}$ & $\begin{array}{l}\text { Straight } \\
\text { Mid } \\
\text { Shank }\end{array}$ & $\begin{array}{l}\text { Angled } \\
\text { Shank }\end{array}$ & $\begin{array}{l}\text { Angled } \\
\text { Mid } \\
\text { Shank }\end{array}$ & $\begin{array}{l}\text { Cracked } \\
\text { Shank }\end{array}$ & $\begin{array}{l}\text { Straight } \\
\text { Fluke }\end{array}$ & $\begin{array}{l}\text { Straight } \\
\text { Fluke } \\
\text { Tip }\end{array}$ & $\begin{array}{l}\text { Angled } \\
\text { Fluke }\end{array}$ & $\begin{array}{c}\text { Angled } \\
\text { Fluke } \\
\text { Tip }\end{array}$ & $\begin{array}{l}\text { Cracked } \\
\text { Fluke }\end{array}$ & $\begin{array}{l}\text { Damaged } \\
\text { Fluke }\end{array}$ & $\begin{array}{l}\text { Damaged/ } \\
\text { Broken } \\
\text { Fluke Tip }\end{array}$ & Pieces & $\begin{array}{l}\text { Station } \\
\text { Number }\end{array}$ & $\begin{array}{l}\text { Distance } \\
\text { from } \\
\text { Baseline }\end{array}$ & $\begin{array}{l}\text { GPS North } \\
\text { (Decimal } \\
\text { degrees) }\end{array}$ & $\begin{array}{l}\text { GPS 38st } \\
\text { (Decimal } \\
\text { degrees) }\end{array}$ \\
\hline 575 & 1 & & & & & & & & & & & & & $251+50$ & 15 & 4132.379 & 8139.442 \\
\hline 576 & 1 & & & & & & & & & & & & & $251+40$ & 15 & 4132.379 & 8139.447 \\
\hline 577 & 2 & & & & & & & & & & & & & $251+40$ & 20 & 4132.380 & 8139.446 \\
\hline 578 & 1 & & & & & & & & & & & & & $251+30$ & 38 & 4132.379 & 8139.449 \\
\hline 579 & & & 1 & & & & & & & & & & & $251+30$ & 10 & 4132.378 & 8139.448 \\
\hline 580 & & & & 1 & & & & & & & & & & $251+30$ & 10 & 4132.378 & 8139.449 \\
\hline 581 & 1 & & & & & & & & & & & & & $251+20$ & 10 & 4132.378 & 8139.449 \\
\hline 582 & & & & 1 & & & & & & & & & & $251+20$ & 10 & 4132.377 & 8139.449 \\
\hline 583 & & & & 1 & & & & & & & & & & $251+30$ & 20 & 4132.379 & 8139.449 \\
\hline 584 & & & & & & & & 1 & & & & & & $251+20$ & 38 & 4132.379 & 8139.450 \\
\hline 585 & & & & & & & & 1 & & & & & & $251+15$ & 10 & & \\
\hline 586 & & & 1 & & & & & & & & & & & $251+10$ & 10 & 4132.377 & 8139.450 \\
\hline 587 & 1 & & & & & & & & & & & & & $251+10$ & 10 & 4132.376 & 8139.452 \\
\hline 588 & & & & & & & & 1 & & & & & & $251+10$ & 20 & 4132.377 & 8139.452 \\
\hline 589 & & & 1 & & & & & & & & & & & $251+05$ & 15 & 4132.376 & 8139.452 \\
\hline 590 & & & 1 & & & & & & & & & & & $251+05$ & 20 & 4132.377 & 8139.453 \\
\hline 591 & & & 1 & & & & & & & & & & & $251+05$ & 25 & 4132.377 & 8139.454 \\
\hline 592 & & & 1 & & & & & & & & & & & $251+10$ & 25 & 4132.376 & 8139.454 \\
\hline 593 & & & 1 & & & & & & & & & & & $251+10$ & 30 & 4132.376 & 8139.455 \\
\hline 594 & & & & & & & & 1 & & & & & & $251+10$ & 30 & & \\
\hline 595 & & & 1 & & & & & & & & & & & $250+85$ & 25 & 4132.375 & 8139.456 \\
\hline 596 & 1 & & & & & & & & & & & & & $250+85$ & 30 & 4132.376 & 8139.456 \\
\hline 597 & & & & & & & & 1 & & & & & & $250+80$ & 25 & 4132.374 & 8139.458 \\
\hline
\end{tabular}




\begin{tabular}{|c|c|c|c|c|c|c|c|c|c|c|c|c|c|c|c|c|c|}
\hline \multirow[t]{2}{*}{$\begin{array}{c}\text { Dolos } \\
\text { Number }\end{array}$} & \multicolumn{13}{|c|}{ Break Type } & \multicolumn{4}{|c|}{ Location } \\
\hline & $\begin{array}{l}\text { Straight } \\
\text { Shank }\end{array}$ & $\begin{array}{l}\text { Straight } \\
\text { Mid } \\
\text { Shank }\end{array}$ & $\begin{array}{l}\text { Angled } \\
\text { Shank }\end{array}$ & $\begin{array}{l}\text { Angled } \\
\text { Mid } \\
\text { Shank }\end{array}$ & $\begin{array}{l}\text { Cracked } \\
\text { Shank }\end{array}$ & $\begin{array}{l}\text { Straight } \\
\text { Fluke }\end{array}$ & $\begin{array}{l}\text { Straight } \\
\text { Fluke } \\
\text { Tip }\end{array}$ & $\begin{array}{l}\text { Angled } \\
\text { Fluke }\end{array}$ & $\begin{array}{c}\text { Angled } \\
\text { Fluke } \\
\text { Tip }\end{array}$ & $\begin{array}{l}\text { Cracked } \\
\text { Fluke }\end{array}$ & $\begin{array}{l}\text { Damaged } \\
\text { Fluke }\end{array}$ & $\begin{array}{l}\text { Damaged/ } \\
\text { Broken } \\
\text { Fluke Tip }\end{array}$ & Pieces & $\begin{array}{l}\text { Station } \\
\text { Number }\end{array}$ & $\begin{array}{l}\text { Distance } \\
\text { from } \\
\text { Baseline }\end{array}$ & $\begin{array}{c}\text { GPS North } \\
\text { (Decimal } \\
\text { degrees) }\end{array}$ & $\begin{array}{l}\text { GPS 38st } \\
\text { (Decimal } \\
\text { degrees) }\end{array}$ \\
\hline 598 & & & & & & & & 1 & & & & & & $250+80$ & 30 & 4132.373 & 8139.458 \\
\hline 599 & 1 & & & & & & & 1 & & & & & & $250+80$ & 25 & 4132.373 & 8139.459 \\
\hline 600 & 1 & & & & & & & & & & & & & $250+85$ & 30 & 4132.372 & 8139.460 \\
\hline 601 & & & 1 & & & & & 1 & & & & & & $250+70$ & 38 & & \\
\hline 602 & & & & & & & & 1 & & & & & & $250+55$ & 20 & 4132.372 & 8139.462 \\
\hline 603 & 1 & & & & & & & & & & & & & $250+55$ & 5 & 4132.370 & 8139.463 \\
\hline 604 & 1 & & & & & 1 & & & & & & & & $250+45$ & 5 & 4132.369 & 8139.463 \\
\hline 605 & 1 & & & & & & & & & & & & & $250+45$ & 25 & 4132.370 & 8139.465 \\
\hline 606 & 1 & & & & & & & & & & & & & $250+45$ & 25 & 4132.371 & 8139.464 \\
\hline 607 & & & & & & 1 & & 1 & & & & & & $250+40$ & 25 & 4132.371 & 8139.464 \\
\hline 608 & 1 & & & & & & & & & & & & & $250+40$ & 15 & 4132.369 & 8139.465 \\
\hline 609 & & & & & & & & 1 & & & & & & $250+35$ & 38 & 4132.371 & 8139.465 \\
\hline 610 & 1 & & & & & & & & & & & & & $250+30$ & 15 & 4132.369 & 8139.466 \\
\hline 611 & & & & & & 1 & & & & & & & & $250+40$ & 38 & 4132.371 & 8139.464 \\
\hline 612 & 1 & & & & & & & & & & & & & $250+25$ & 15 & 4132.369 & 8139.467 \\
\hline 613 & 1 & & & & & & & & & & & & & $250+30$ & 25 & 4132.370 & 8139.467 \\
\hline 614 & & & 1 & & & & & & & & & & & $250+35$ & 38 & 4132.370 & 8139.467 \\
\hline 615 & & & 1 & & & & & & & & & & & $250+30$ & 20 & 4132.370 & 8139.466 \\
\hline 616 & & & 1 & & & & & & & & & & & $250+30$ & 38 & 4132.367 & 8139.468 \\
\hline 617 & & & 1 & & & & & & & & & & & $250+20$ & 25 & 4132.368 & 8139.469 \\
\hline 618 & 1 & & & & & & & & & & & & & $250+20$ & 5 & 4132.367 & 8139.467 \\
\hline 619 & & & 1 & & & & & & & & & & & $250+20$ & 10 & 4132.367 & 8139.469 \\
\hline 620 & 1 & & & & & & & & & & & & & $250+10$ & 10 & 4132.367 & 8139.470 \\
\hline
\end{tabular}




\begin{tabular}{|c|c|c|c|c|c|c|c|c|c|c|c|c|c|c|c|c|c|}
\hline \multirow[t]{2}{*}{$\begin{array}{l}\text { Dolos } \\
\text { Number }\end{array}$} & \multicolumn{13}{|c|}{ Break Type } & \multicolumn{4}{|c|}{ Location } \\
\hline & $\begin{array}{l}\text { Straight } \\
\text { Shank }\end{array}$ & $\begin{array}{l}\text { Straight } \\
\text { Mid } \\
\text { Shank }\end{array}$ & $\begin{array}{l}\text { Angled } \\
\text { Shank }\end{array}$ & $\begin{array}{c}\text { Angled } \\
\text { Mid } \\
\text { Shank }\end{array}$ & $\begin{array}{l}\text { Cracked } \\
\text { Shank }\end{array}$ & $\begin{array}{l}\text { Straight } \\
\text { Fluke }\end{array}$ & $\begin{array}{l}\text { Straight } \\
\text { Fluke } \\
\text { Tip }\end{array}$ & $\begin{array}{l}\text { Angled } \\
\text { Fluke }\end{array}$ & $\begin{array}{c}\text { Angled } \\
\text { Fluke } \\
\text { Tip }\end{array}$ & $\begin{array}{l}\text { Cracked } \\
\text { Fluke }\end{array}$ & $\begin{array}{l}\text { Damaged } \\
\text { Fluke }\end{array}$ & $\begin{array}{l}\text { Damaged/ } \\
\text { Broken } \\
\text { Fluke Tip }\end{array}$ & Pieces & $\begin{array}{l}\text { Station } \\
\text { Number }\end{array}$ & $\begin{array}{l}\text { Distance } \\
\text { from } \\
\text { Baseline }\end{array}$ & $\begin{array}{l}\text { GPS North } \\
\text { (Decimal } \\
\text { degrees) }\end{array}$ & $\begin{array}{l}\text { GPS 38st } \\
\text { (Decimal } \\
\text { degrees) }\end{array}$ \\
\hline 621 & & & & & & & & 1 & & & & & & $250+15$ & 15 & 4132.367 & 8139.470 \\
\hline 622 & 1 & & & & & & & & & & & & & $250+15$ & 10 & 4132.367 & 8139.469 \\
\hline 623 & 1 & & & & & & & & & & & & & $250+15$ & 38 & & \\
\hline 624 & & & 1 & & & & & & & & & & & $250+20$ & 38 & 4132.367 & 8139.470 \\
\hline 625 & & & 1 & & & & & & & & & & & $250+00$ & 10 & 4132.364 & 8139.473 \\
\hline 626 & 1 & & & & & & & & & & & & & $250+05$ & 20 & 4132.367 & 8139.471 \\
\hline 627 & & & 1 & & & & & & & & & & & $250+05$ & 30 & 4132.366 & 8139.471 \\
\hline 628 & 1 & & & & & & & & & & & & & $250+10$ & 30 & 4132.368 & 8139.469 \\
\hline 629 & & & 1 & & & & & & & & & & & $250+05$ & 38 & 4132.366 & 8139.472 \\
\hline 630 & 1 & & & & & & & & & & & & & $250+15$ & 38 & 4132.366 & 8139.472 \\
\hline 631 & 1 & & & & & & & & & & & & & $249+90$ & 10 & 4132.364 & 8139.474 \\
\hline 632 & 1 & & & & & & & & & & & & & $249+95$ & 15 & 4132.364 & 8139.473 \\
\hline 633 & & & 1 & & & & & & & & & & & $249+80$ & 25 & 4132.363 & 8139.478 \\
\hline 634 & & & 1 & & & & & & & & & & & $249+85$ & 38 & & \\
\hline 635 & & & & & & 1 & & & & & & & & $249+80$ & 38 & 4132.364 & 8139.479 \\
\hline 636 & 1 & & & & & & & & & & & & & $249+85$ & 38 & 4132.364 & 8139.477 \\
\hline 637 & & & 1 & & & & & & & & & & & $249+65$ & 30 & 4132.361 & 8139.480 \\
\hline 638 & & & & & & & & & & & & & 1 & $249+60$ & 30 & 4132.360 & 8139.481 \\
\hline 639 & 1 & & & & & & & & & & & & & $249+60$ & 30 & 4132.361 & 8139.482 \\
\hline 640 & 1 & & & & & & & & & & & & & $249+55$ & 38 & 4132.361 & 8139.482 \\
\hline 641 & & & 1 & & & & & & & & & & & $249+55$ & 25 & 4132.361 & 8139.483 \\
\hline 642 & & 1 & & & & & & & & & & & & $249+55$ & 25 & 4132.360 & 8139.481 \\
\hline 643 & & & 1 & & & & & & & & & & & $249+50$ & 20 & 4132.360 & 8139.483 \\
\hline
\end{tabular}




\begin{tabular}{|c|c|c|c|c|c|c|c|c|c|c|c|c|c|c|c|c|c|}
\hline \multirow[t]{2}{*}{$\begin{array}{c}\text { Dolos } \\
\text { Number }\end{array}$} & \multicolumn{13}{|c|}{ Break Type } & \multicolumn{4}{|c|}{ Location } \\
\hline & $\begin{array}{l}\text { Straight } \\
\text { Shank }\end{array}$ & $\begin{array}{l}\text { Straight } \\
\text { Mid } \\
\text { Shank }\end{array}$ & $\begin{array}{l}\text { Angled } \\
\text { Shank }\end{array}$ & $\begin{array}{l}\text { Angled } \\
\text { Mid } \\
\text { Shank }\end{array}$ & $\begin{array}{l}\text { Cracked } \\
\text { Shank }\end{array}$ & $\begin{array}{l}\text { Straight } \\
\text { Fluke }\end{array}$ & $\begin{array}{l}\text { Straight } \\
\text { Fluke } \\
\text { Tip }\end{array}$ & $\begin{array}{l}\text { Angled } \\
\text { Fluke }\end{array}$ & $\begin{array}{c}\text { Angled } \\
\text { Fluke } \\
\text { Tip }\end{array}$ & $\begin{array}{l}\text { Cracked } \\
\text { Fluke }\end{array}$ & $\begin{array}{l}\text { Damaged } \\
\text { Fluke }\end{array}$ & $\begin{array}{l}\text { Damaged/ } \\
\text { Broken } \\
\text { Fluke Tip }\end{array}$ & Pieces & $\begin{array}{l}\text { Station } \\
\text { Number }\end{array}$ & $\begin{array}{l}\text { Distance } \\
\text { from } \\
\text { Baseline }\end{array}$ & $\begin{array}{l}\text { GPS North } \\
\text { (Decimal } \\
\text { degrees) }\end{array}$ & $\begin{array}{l}\text { GPS 38st } \\
\text { (Decimal } \\
\text { degrees) }\end{array}$ \\
\hline 644 & & & 1 & & & & & & & & & & & $249+45$ & 25 & 4132.358 & 8139.484 \\
\hline 645 & 1 & & & & & & & & & & & & & $249+45$ & 20 & 4132.358 & 8139.483 \\
\hline 646 & & & & & & & & & & & & & 1 & $249+50$ & 38 & 4132.357 & 8139.483 \\
\hline $646 \mathrm{~A}$ & & & & & & 1 & & & & & & & & $249+35$ & 15 & 4132.357 & 8139.483 \\
\hline $646 \mathrm{~B}$ & & & & & & 1 & & & & & & & & $249+45$ & 38 & 4132.358 & 8139.484 \\
\hline 647 & 1 & & & & & & & & & & & & & $249+30$ & 20 & 4132.358 & 8139.485 \\
\hline 648 & 1 & & & & & & & & & & & & & $249+25$ & 5 & 4132.356 & 8139.485 \\
\hline 649 & 1 & & & & & & & 2 & & & & & & $249+25$ & 20 & 4132.358 & 8139.487 \\
\hline 650 & & & & & & 1 & & & & & & & & $249+20$ & 38 & 4132.358 & 8139.488 \\
\hline 651 & & & & & & 1 & & & & & & & & $249+15$ & 38 & 4132.357 & 8139.489 \\
\hline 652 & & & 1 & & & & & & & & & & & $249+10$ & 30 & 4132.355 & 8139.492 \\
\hline 653 & & & & & & 1 & & & & & & & & $249+15$ & 25 & 4132.354 & 8139.492 \\
\hline 654 & & & & & & & & 1 & & & & & & $248+85$ & 38 & 4132.355 & 8139.493 \\
\hline 655 & 1 & & & & & 1 & & & & & & & & $247+25$ & 38 & 4132.337 & 8139.522 \\
\hline 656 & & & & & & & & 1 & & & & & & $248+85$ & 25 & 4132.352 & 8139.493 \\
\hline 657 & 1 & & & & & & & 1 & & & & & & $248+85$ & 30 & 4132.353 & 8139.494 \\
\hline 658 & 1 & & & & & & & & & & & & & $248+75$ & 20 & 4132.353 & 8139.495 \\
\hline 659 & & & & & & & & 2 & & & & & & $248+65$ & 15 & 4132.350 & 8139.498 \\
\hline 660 & 1 & & & & & & & & & & & & & $248+65$ & 25 & 4132.351 & 8139.498 \\
\hline 661 & 1 & & & & & & & & & & & & & $248+65$ & 38 & 4132.351 & 8139.498 \\
\hline 662 & 1 & & & & & & & & & & & & & $248+65$ & 25 & 4132.351 & 8139.499 \\
\hline 663 & 1 & & & & & & & & & & & & & $248+60$ & 15 & 4132.350 & 8139.499 \\
\hline 664 & & & & 1 & & & & & & & & & & $248+50$ & 15 & 4132.350 & 8139.499 \\
\hline
\end{tabular}




\begin{tabular}{|c|c|c|c|c|c|c|c|c|c|c|c|c|c|c|c|c|c|}
\hline $\begin{array}{l}\text { Dolos } \\
\text { Number }\end{array}$ & \multicolumn{13}{|c|}{ Break Type } & \multicolumn{4}{|c|}{ Location } \\
\hline & $\begin{array}{l}\text { Straight } \\
\text { Shank }\end{array}$ & $\begin{array}{l}\text { Straight } \\
\text { Mid } \\
\text { Shank }\end{array}$ & $\begin{array}{l}\text { Angled } \\
\text { Shank }\end{array}$ & $\begin{array}{l}\text { Angled } \\
\text { Mid } \\
\text { Shank }\end{array}$ & $\begin{array}{l}\text { Cracked } \\
\text { Shank }\end{array}$ & $\begin{array}{l}\text { Straight } \\
\text { Fluke }\end{array}$ & $\begin{array}{l}\text { Straight } \\
\text { Fluke } \\
\text { Tip }\end{array}$ & $\begin{array}{l}\text { Angled } \\
\text { Fluke }\end{array}$ & $\begin{array}{l}\text { Angled } \\
\text { Fluke } \\
\text { Tip }\end{array}$ & $\begin{array}{l}\text { Cracked } \\
\text { Fluke }\end{array}$ & $\begin{array}{l}\text { Damaged } \\
\text { Fluke }\end{array}$ & $\begin{array}{c}\text { Damaged/ } \\
\text { Broken } \\
\text { Fluke Tip }\end{array}$ & Pieces & $\begin{array}{l}\text { Station } \\
\text { Number }\end{array}$ & $\begin{array}{c}\text { Distance } \\
\text { from } \\
\text { Baseline }\end{array}$ & $\begin{array}{c}\text { GPS North } \\
\text { (Decimal } \\
\text { degrees) }\end{array}$ & $\begin{array}{l}\text { GPS 38st } \\
\text { (Decimal } \\
\text { degrees) }\end{array}$ \\
\hline 665 & 1 & & & & & & & & & & & & & $248+55$ & 25 & 4132.351 & 8139.500 \\
\hline 666 & & & & & & & & 1 & & & & & & $248+50$ & 25 & 4132.350 & 8139.500 \\
\hline 667 & 1 & & & & & & & & & & & & & $248+40$ & 38 & 4132.349 & 8139.502 \\
\hline 668 & & & & & & 1 & & & & & & & & $248+35$ & 25 & 4132.349 & 8139.502 \\
\hline 669 & & & 1 & & & & & & 1 & & & & & $248+25$ & 25 & 4132.348 & 8139.503 \\
\hline 670 & & & 1 & & & & & & & & & & & $248+30$ & 5 & 4132.347 & 8139.501 \\
\hline 671 & & 1 & & & & & & & & & & & & $248+10$ & 25 & 4132.346 & 8139.504 \\
\hline 672 & & 1 & & & & & & & & & & & & $248+00$ & 38 & 4132.346 & 8139.505 \\
\hline 673 & & & & & & & & & & & & & & $247+95$ & 38 & & \\
\hline 674 & 1 & & & & & & & & & & & & & $248+00$ & 25 & 4132.345 & 8139.507 \\
\hline 675 & & & 1 & & & & & & & & & & & $247+95$ & 20 & 4132.345 & 8139.510 \\
\hline 676 & 1 & & & & & & & & & & & & & $248+00$ & 20 & 4132.345 & 8139.509 \\
\hline 677 & & & & & & & & 2 & & & & & & $247+90$ & 30 & 4132.344 & 8139.509 \\
\hline \multicolumn{18}{|l|}{678} \\
\hline 679 & 1 & & & & & & & & & & & & & $247+80$ & 25 & 4132.344 & 8139.511 \\
\hline 680 & & & 1 & & & & & & & & & & & $247+80$ & 38 & 4132.344 & 8139.509 \\
\hline 681 & 1 & & & & & & & & & & & & & $247+65$ & 15 & 4132.341 & 8139.514 \\
\hline 682 & & & & 1 & & & & & & & & & & $247+60$ & 20 & 4132.341 & 8139.516 \\
\hline 683 & & & & & & & & & & 1 & & & & $247+60$ & 25 & 4132.341 & 8139.516 \\
\hline 684 & & & & & & & & & 1 & & & & & $247+55$ & 38 & 4132.341 & 8139.516 \\
\hline 685 & 1 & & & & & 1 & & & & & & & & $247+50$ & 30 & 4132.341 & 8139.517 \\
\hline 686 & & & 1 & & & & & & & & & & & $247+50$ & 38 & 4132.341 & 8139.518 \\
\hline 687 & & & & & & & & 2 & & & & & & $247+50$ & 30 & 4132.340 & 8139.518 \\
\hline
\end{tabular}




\begin{tabular}{|c|c|c|c|c|c|c|c|c|c|c|c|c|c|c|c|c|c|}
\hline \multirow[t]{2}{*}{$\begin{array}{c}\text { Dolos } \\
\text { Number }\end{array}$} & \multicolumn{13}{|c|}{ Break Type } & \multicolumn{4}{|c|}{ Location } \\
\hline & $\begin{array}{l}\text { Straight } \\
\text { Shank }\end{array}$ & $\begin{array}{l}\text { Straight } \\
\text { Mid } \\
\text { Shank }\end{array}$ & $\begin{array}{l}\text { Angled } \\
\text { Shank }\end{array}$ & $\begin{array}{l}\text { Angled } \\
\text { Mid } \\
\text { Shank }\end{array}$ & $\begin{array}{l}\text { Cracked } \\
\text { Shank }\end{array}$ & $\begin{array}{c}\text { Straight } \\
\text { Fluke }\end{array}$ & $\begin{array}{l}\text { Straight } \\
\text { Fluke } \\
\text { Tip }\end{array}$ & $\begin{array}{l}\text { Angled } \\
\text { Fluke }\end{array}$ & $\begin{array}{c}\text { Angled } \\
\text { Fluke } \\
\text { Tip }\end{array}$ & $\begin{array}{l}\text { Cracked } \\
\text { Fluke }\end{array}$ & $\begin{array}{l}\text { Damaged } \\
\text { Fluke }\end{array}$ & $\begin{array}{c}\text { Damaged/ } \\
\text { Broken } \\
\text { Fluke Tip }\end{array}$ & Pieces & $\begin{array}{l}\text { Station } \\
\text { Number }\end{array}$ & $\begin{array}{l}\text { Distance } \\
\text { from } \\
\text { Baseline }\end{array}$ & $\begin{array}{c}\text { GPS North } \\
\text { (Decimal } \\
\text { degrees) }\end{array}$ & $\begin{array}{l}\text { GPS 38st } \\
\text { (Decimal } \\
\text { degrees) }\end{array}$ \\
\hline 688 & & & & & & & & 1 & & & & & & $247+45$ & 30 & 4132.340 & 8139.519 \\
\hline 689 & & & & & & 1 & & & & & & & & $247+40$ & 25 & 4132.339 & 8139.520 \\
\hline 690 & & 1 & & & & & & & & & & & & $247+45$ & 38 & 4132.339 & 8139.519 \\
\hline 691 & 1 & & & & & & & & & & & & & $247+40$ & 38 & 4132.339 & 8139.520 \\
\hline 692 & 1 & & & & & & & & & & & & & $247+30$ & 30 & 4132.339 & 8139.521 \\
\hline 693 & & & 1 & & & & & & & & & & & $247+30$ & 20 & 4132.338 & 8139.521 \\
\hline 694 & 1 & & & & & & & & & & & & & $247+25$ & 15 & 4132.338 & 8139.521 \\
\hline 695 & & & & 1 & & & & & & & & & & $247+25$ & 0 & 4132.336 & 8139.519 \\
\hline 696 & 1 & & & & & & & & & & & & & $247+25$ & 30 & 4132.338 & 8139.522 \\
\hline 697 & 1 & & & & & & & & & & & & & $247+20$ & 25 & 4132.337 & 8139.523 \\
\hline 698 & 1 & & & & & & & & & & & & & $247+10$ & 30 & 4132.337 & 8139.524 \\
\hline 699 & 1 & & & & & & & & & & & & & $247+10$ & 38 & 4132.336 & 8139.525 \\
\hline 700 & & & & & & 1 & & & & & & & & $247+05$ & 25 & 4132.335 & 8139.525 \\
\hline 701 & & 1 & & & & & & & & & & & & $247+00$ & 5 & 4132.335 & 8139.525 \\
\hline 702 & & & 1 & & & & & & & & & & & $246+90$ & 20 & 4132.336 & 8139.523 \\
\hline 703 & 1 & & & & & & & & & & & & & $246+85$ & 20 & 4132.335 & 8139.524 \\
\hline 704 & 1 & & & & & & & & & & & & & $246+65$ & 25 & 4132.332 & 8139.532 \\
\hline 705 & & & 1 & & & & & & & & & & & $246+65$ & 25 & 4132.332 & 8139.532 \\
\hline 706 & 1 & & & & & & & & & & & & & $246+55$ & 20 & 4132.330 & 8139.534 \\
\hline 707 & & 1 & & & & & & & & & & & & $246+55$ & 25 & 4132.330 & 8139.536 \\
\hline $707 A$ & 1 & & & & & & & & & & & & & $246+55$ & 0 & 4132.327 & 8139.532 \\
\hline 708 & & & 1 & & & & & & & & & & & $246+40$ & 10 & 4132.327 & 8139.535 \\
\hline 709 & & & & & & & & 1 & & & & & & $246+30$ & 20 & 4132.329 & 8139.538 \\
\hline
\end{tabular}




\begin{tabular}{|c|c|c|c|c|c|c|c|c|c|c|c|c|c|c|c|c|c|}
\hline \multirow[t]{2}{*}{$\begin{array}{l}\text { Dolos } \\
\text { Number }\end{array}$} & \multicolumn{13}{|c|}{ Break Type } & \multicolumn{4}{|c|}{ Location } \\
\hline & $\begin{array}{l}\text { Straight } \\
\text { Shank }\end{array}$ & $\begin{array}{l}\text { Straight } \\
\text { Mid } \\
\text { Shank }\end{array}$ & $\begin{array}{l}\text { Angled } \\
\text { Shank }\end{array}$ & $\begin{array}{l}\text { Angled } \\
\text { Mid } \\
\text { Shank }\end{array}$ & $\begin{array}{l}\text { Cracked } \\
\text { Shank }\end{array}$ & $\begin{array}{l}\text { Straight } \\
\text { Fluke }\end{array}$ & $\begin{array}{l}\text { Straight } \\
\text { Fluke } \\
\text { Tip }\end{array}$ & $\begin{array}{l}\text { Angled } \\
\text { Fluke }\end{array}$ & $\begin{array}{l}\text { Angled } \\
\text { Fluke } \\
\text { Tip }\end{array}$ & $\begin{array}{l}\text { Cracked } \\
\text { Fluke }\end{array}$ & $\begin{array}{l}\text { Damaged } \\
\text { Fluke }\end{array}$ & $\begin{array}{l}\text { Damaged/ } \\
\text { Broken } \\
\text { Fluke Tip }\end{array}$ & Pieces & $\begin{array}{l}\text { Station } \\
\text { Number }\end{array}$ & $\begin{array}{l}\text { Distance } \\
\text { from } \\
\text { Baseline }\end{array}$ & $\begin{array}{l}\text { GPS North } \\
\text { (Decimal } \\
\text { degrees) }\end{array}$ & $\begin{array}{l}\text { GPS 38st } \\
\text { (Decimal } \\
\text { degrees) }\end{array}$ \\
\hline 710 & & & 1 & & & 1 & & & & & & & & $246+35$ & 38 & 4132.329 & 8139.538 \\
\hline 711 & 1 & & & & & & & & & & & & & $246+30$ & 15 & 4132.327 & 8139.536 \\
\hline 712 & & & 1 & & & & & & & & & & & $246+25$ & 15 & 4132.328 & 8139.536 \\
\hline 713 & & & & & & & & 1 & & & & & & $246+20$ & 10 & 4132.327 & 8139.537 \\
\hline 714 & & & 1 & & & & & & & & & & & $246+20$ & 20 & 4132.327 & 8139.539 \\
\hline 715 & 1 & & & & & & & & & & & & & $246+15$ & 20 & 4132.326 & 8139.542 \\
\hline 716 & & & 1 & & & & & & & & & & & $246+10$ & 20 & 4132.326 & 8139.543 \\
\hline 717 & 1 & & & & & & & & & & & & & $246+05$ & 20 & 4132.325 & 8139.543 \\
\hline 718 & 1 & & & & & & & & & & & & & $246+05$ & 20 & 4132.325 & 8139.543 \\
\hline 719 & & & 1 & & & & & & & & & & & $246+05$ & 25 & 4132.325 & 8139.543 \\
\hline 720 & & & & & & 1 & & & & & & & & $246+00$ & 20 & 4132.324 & 8139.544 \\
\hline 721 & & & 1 & & & & & & & & & & & $246+00$ & 0 & 4132.323 & 8139.543 \\
\hline 722 & & & & & & 1 & & & & & & & & $245+95$ & 15 & 4132.324 & 8139.543 \\
\hline 723 & & & & & & 1 & & & & & & & & $245+95$ & 38 & 4132.325 & 8139.546 \\
\hline 724 & & & & 1 & & & & & & & & & & $245+85$ & 38 & 4132.324 & 8139.547 \\
\hline $724 \mathrm{~A}$ & & & & & & 1 & & 1 & & & & & & $245+90$ & -10 & 4132.321 & 8139.544 \\
\hline 725 & 1 & & & & & & & & & & & & & $245+70$ & 25 & 4132.321 & 8139.550 \\
\hline 726 & & & 1 & & & & & & & & & & & $245+80$ & 5 & 4132.322 & 8139.547 \\
\hline 727 & 1 & & & & & & & & & & & & & $245+45$ & 38 & 4132.321 & 8139.553 \\
\hline 728 & & & 1 & & & 1 & & & & & & & & $245+55$ & 38 & 4132.323 & 8139.553 \\
\hline 729 & 1 & & & & & & & & & & & & & $245+40$ & 25 & 4132.320 & 8139.553 \\
\hline 730 & 1 & & & & & & & & & & & & & $245+40$ & 38 & 4132.320 & 8139.554 \\
\hline 731 & 1 & & & & & & & & & & & & & $245+35$ & 25 & 4132.319 & 8139.555 \\
\hline
\end{tabular}




\begin{tabular}{|c|c|c|c|c|c|c|c|c|c|c|c|c|c|c|c|c|c|}
\hline $\begin{array}{l}\text { Dolos } \\
\text { Number }\end{array}$ & \multicolumn{13}{|c|}{ Break Type } & \multicolumn{4}{|c|}{ Location } \\
\hline & $\begin{array}{l}\text { Straight } \\
\text { Shank }\end{array}$ & $\begin{array}{l}\text { Straight } \\
\text { Mid } \\
\text { Shank }\end{array}$ & $\begin{array}{l}\text { Angled } \\
\text { Shank }\end{array}$ & $\begin{array}{l}\text { Angled } \\
\text { Mid } \\
\text { Shank }\end{array}$ & $\begin{array}{l}\text { Cracked } \\
\text { Shank }\end{array}$ & $\begin{array}{l}\text { Straight } \\
\text { Fluke }\end{array}$ & $\begin{array}{l}\text { Straight } \\
\text { Fluke } \\
\text { Tip }\end{array}$ & $\begin{array}{l}\text { Angled } \\
\text { Fluke }\end{array}$ & $\begin{array}{l}\text { Angled } \\
\text { Fluke } \\
\text { Tip }\end{array}$ & $\begin{array}{l}\text { Cracked } \\
\text { Fluke }\end{array}$ & $\begin{array}{l}\text { Damaged } \\
\text { Fluke }\end{array}$ & $\begin{array}{l}\text { Damaged/ } \\
\text { Broken } \\
\text { Fluke Tip }\end{array}$ & Pieces & $\begin{array}{l}\text { Station } \\
\text { Number }\end{array}$ & $\begin{array}{l}\text { Distance } \\
\text { from } \\
\text { Baseline }\end{array}$ & $\begin{array}{l}\text { GPS North } \\
\text { (Decimal } \\
\text { degrees) }\end{array}$ & $\begin{array}{l}\text { GPS 38st } \\
\text { (Decimal } \\
\text { degrees) }\end{array}$ \\
\hline 732 & 1 & & & & & & & & & & & & & $245+35$ & 38 & 4132.320 & 8139.556 \\
\hline 733 & 1 & & & & & & & 1 & & & & & & $245+30$ & 30 & 4132.320 & 8139.556 \\
\hline $733 A$ & & & & & & 1 & & & & & & & & $245+30$ & 30 & 4132.319 & 8139.556 \\
\hline 734 & & & & & & & & & & & & & & & & & \\
\hline 735 & & & & & & & & 1 & & & & & & $245+25$ & 20 & 4132.320 & 8139.558 \\
\hline 736 & & & 1 & & & & & & & & & & & $245+25$ & 38 & 4132.319 & 8139.556 \\
\hline 737 & & & 1 & & & & & & & & & & & $245+20$ & 5 & 4132.316 & 8139.557 \\
\hline 738 & & & 1 & & & & & 1 & & & & & & $245+15$ & 15 & 4132.316 & 8139.558 \\
\hline 739 & 1 & & & & & & & & & & & & & $245+10$ & 15 & 4132.315 & 8139.559 \\
\hline 740 & 1 & & & & & & & & & & & & & $245+05$ & 5 & 4132.315 & 8139.560 \\
\hline 741 & 1 & & & & & & & & & & & & & $244+95$ & 20 & 4132.315 & 8139.562 \\
\hline 742 & 1 & & & & & & & & & & & & & $244+85$ & 15 & 4132.314 & 8139.565 \\
\hline $742 A$ & & 1 & & & & & & & & & & & & $244+80$ & 0 & 4132.312 & 8139.564 \\
\hline 743 & & & & & & & & 1 & & & & & & $244+75$ & 20 & 4132.312 & 8139.566 \\
\hline 744 & & & & & & & & & 1 & & & & & $244+75$ & 20 & 4132.312 & 8139.567 \\
\hline 745 & & & & & & & & 1 & & & & & & $244+55$ & 38 & 4132.311 & 8139.570 \\
\hline 746 & & & 1 & & & & & & & & & & & $244+45$ & 30 & 4132.310 & 8139.571 \\
\hline 747 & 1 & & & & & & & & & & & & & $244+45$ & 20 & 4132.309 & 8139.572 \\
\hline 748 & & & & & & & & 1 & & & & & & $244+45$ & 15 & 4132.309 & 8139.571 \\
\hline 749 & & & & & & & & 1 & & & & & & $244+40$ & 15 & 4132.309 & 8139.572 \\
\hline 750 & 1 & & & & & & & & & & & & & $244+40$ & 10 & 4132.308 & 8139.572 \\
\hline $750 \mathrm{~A}$ & 1 & & & & & & & & & & & & & $244+55$ & 10 & 4132.309 & 8139.569 \\
\hline 751 & & & & 1 & & & & & & & & & & $244+30$ & 10 & 4132.307 & 8139.573 \\
\hline
\end{tabular}




\begin{tabular}{|c|c|c|c|c|c|c|c|c|c|c|c|c|c|c|c|c|c|}
\hline $\begin{array}{l}\text { Dolos } \\
\text { Number }\end{array}$ & \multicolumn{13}{|c|}{ Break Type } & \multicolumn{4}{|c|}{ Location } \\
\hline & $\begin{array}{l}\text { Straight } \\
\text { Shank }\end{array}$ & $\begin{array}{l}\text { Straight } \\
\text { Mid } \\
\text { Shank }\end{array}$ & $\begin{array}{l}\text { Angled } \\
\text { Shank }\end{array}$ & $\begin{array}{l}\text { Angled } \\
\text { Mid } \\
\text { Shank }\end{array}$ & $\begin{array}{l}\text { Cracked } \\
\text { Shank }\end{array}$ & $\begin{array}{l}\text { Straight } \\
\text { Fluke }\end{array}$ & $\begin{array}{c}\text { Straight } \\
\text { Fluke } \\
\text { Tip }\end{array}$ & $\begin{array}{l}\text { Angled } \\
\text { Fluke }\end{array}$ & $\begin{array}{c}\text { Angled } \\
\text { Fluke } \\
\text { Tip }\end{array}$ & $\begin{array}{l}\text { Cracked } \\
\text { Fluke }\end{array}$ & $\begin{array}{l}\text { Damaged } \\
\text { Fluke }\end{array}$ & $\begin{array}{l}\text { Damaged/ } \\
\text { Broken } \\
\text { Fluke Tip }\end{array}$ & Pieces & $\begin{array}{l}\text { Station } \\
\text { Number }\end{array}$ & $\begin{array}{c}\text { Distance } \\
\text { from } \\
\text { Baseline }\end{array}$ & $\begin{array}{l}\text { GPS North } \\
\text { (Decimal } \\
\text { degrees) }\end{array}$ & $\begin{array}{l}\text { GPS 38st } \\
\text { (Decimal } \\
\text { degrees) }\end{array}$ \\
\hline 752 & 1 & & & & & & & & & & & & & $244+25$ & 20 & 4132.308 & 8139.574 \\
\hline 753 & 1 & & & & & & & & & & & & & $244+20$ & 10 & 4132.306 & 8139.575 \\
\hline 754 & 1 & & & & & & & & & & & & & $244+20$ & 15 & 4132.306 & 8139.576 \\
\hline 755 & & & 1 & & & & & & & & & & & $244+20$ & 25 & 4132.306 & 8139.577 \\
\hline 756 & & & 1 & & & & & & & & & & & $244+20$ & 20 & 4132.306 & 8139.577 \\
\hline 757 & 1 & & & & & & & & & & & & & $244+25$ & 38 & 4132.308 & 8139.577 \\
\hline 758 & 1 & & & & & & & & & & & & & $244+20$ & 38 & 4132.307 & 8139.577 \\
\hline 759 & 1 & & & & & & & & & & & & & $244+15$ & 38 & 4132.307 & 8139.577 \\
\hline $759 A$ & & & 1 & & & & & & & & & & & $244+25$ & 15 & 4132.306 & 8139.576 \\
\hline 760 & 1 & & & & & & & & & & & & & $244+00$ & 15 & 4132.304 & 8139.580 \\
\hline 761 & 1 & & & & & & & & & & & & & $243+95$ & 20 & 4132.304 & 8139.581 \\
\hline 762 & & & 1 & & & & & & & & & & & $244+00$ & 38 & 4132.305 & 8139.581 \\
\hline 763 & & & 1 & & & & & & & & & & & $243+90$ & 15 & 4132.303 & 8139.582 \\
\hline 764 & & & & & & & & & 1 & & & & & $243+85$ & 15 & 4132.302 & 8139.583 \\
\hline 765 & & & 1 & & & & & & & & & & & $243+80$ & 20 & 4132.303 & 8139.584 \\
\hline 766 & 1 & & & & & & & & & & & & & $243+75$ & 15 & 4132.302 & 8139.584 \\
\hline 767 & & & 1 & & & & & & & & & & & $243+70$ & 20 & 4132.301 & 8139.585 \\
\hline 768 & 1 & & & & & & & & & & & & & $243+65$ & 15 & 4132.301 & 8139.585 \\
\hline 769 & & & & & & & & & & & & & & & & & \\
\hline 770 & & & & & & 1 & & & & & & & & $243+75$ & 38 & 4132.303 & 8139.585 \\
\hline 771 & & & & & & & & 1 & & & & & & $243+65$ & 25 & 4132.302 & 8139.587 \\
\hline 772 & 1 & & & & & & & & & & & & & $243+55$ & 38 & 4132.300 & 8139.588 \\
\hline 773 & & & & & & 1 & & & & & & & & $243+50$ & 38 & 4132.301 & 8139.589 \\
\hline
\end{tabular}




\begin{tabular}{|c|c|c|c|c|c|c|c|c|c|c|c|c|c|c|c|c|c|}
\hline \multirow[t]{2}{*}{$\begin{array}{l}\text { Dolos } \\
\text { Number }\end{array}$} & \multicolumn{13}{|c|}{ Break Type } & \multicolumn{4}{|c|}{ Location } \\
\hline & $\begin{array}{l}\text { Straight } \\
\text { Shank }\end{array}$ & $\begin{array}{l}\text { Straight } \\
\text { Mid } \\
\text { Shank }\end{array}$ & $\begin{array}{l}\text { Angled } \\
\text { Shank }\end{array}$ & $\begin{array}{l}\text { Angled } \\
\text { Mid } \\
\text { Shank }\end{array}$ & $\begin{array}{l}\text { Cracked } \\
\text { Shank }\end{array}$ & $\begin{array}{l}\text { Straight } \\
\text { Fluke }\end{array}$ & $\begin{array}{l}\text { Straight } \\
\text { Fluke } \\
\text { Tip }\end{array}$ & $\begin{array}{l}\text { Angled } \\
\text { Fluke }\end{array}$ & $\begin{array}{l}\text { Angled } \\
\text { Fluke } \\
\text { Tip }\end{array}$ & $\begin{array}{l}\text { Cracked } \\
\text { Fluke }\end{array}$ & $\begin{array}{l}\text { Damaged } \\
\text { Fluke }\end{array}$ & $\begin{array}{l}\text { Damaged/ } \\
\text { Broken } \\
\text { Fluke Tip }\end{array}$ & Pieces & $\begin{array}{l}\text { Station } \\
\text { Number }\end{array}$ & $\begin{array}{l}\text { Distance } \\
\text { from } \\
\text { Baseline }\end{array}$ & $\begin{array}{l}\text { GPS North } \\
\text { (Decimal } \\
\text { degrees) }\end{array}$ & $\begin{array}{l}\text { GPS 38st } \\
\text { (Decimal } \\
\text { degrees) }\end{array}$ \\
\hline 774 & 1 & & & & & & & & & & & & & $243+40$ & 38 & 4132.301 & 8139.591 \\
\hline 775 & & 1 & & & & & & & & & & & & $243+35$ & 38 & 4132.299 & 8139.593 \\
\hline 776 & 1 & & & & & & & & & & & & & $243+30$ & 38 & 4132.299 & 8139.593 \\
\hline 777 & 1 & & & & & & & & & & & & & $243+30$ & 38 & 4132.299 & 8139.593 \\
\hline 778 & 1 & & & & & & & & & & & & & $243+05$ & 20 & 4132.296 & 8139.596 \\
\hline 779 & & & & & & & & 1 & & & & & & $243+00$ & 38 & 4132.296 & 8139.597 \\
\hline 780 & 1 & & & & & & & & & & & & & $243+05$ & 10 & 4132.295 & 8139.596 \\
\hline 781 & & & 1 & & & & & & & & & & & $242+95$ & 10 & 4132.294 & 8139.597 \\
\hline 782 & 1 & & & & & & & & & & & & & $242+95$ & 25 & 4132.295 & 8139.598 \\
\hline 783 & & 1 & & & & & & & & & & & & $243+00$ & 25 & 4132.295 & 8139.599 \\
\hline 784 & 1 & & & & & & & & & & & & & $242+95$ & 38 & 4132.295 & 8139.598 \\
\hline 785 & & & 1 & & & & & & & & & & & $242+85$ & 10 & 4132.293 & 8139.598 \\
\hline 786 & & & & & & & 1 & & & & & & & $242+85$ & 38 & 4132.294 & 8139.600 \\
\hline 787 & & & 1 & & & & & & & & & & & $242+75$ & 5 & 4132.291 & 8139.600 \\
\hline 788 & 1 & & & & & & & & & & & & & $242+75$ & 25 & 4132.292 & 8139.603 \\
\hline 789 & & & & & & 1 & & & & & & & & $242+70$ & 38 & 4132.292 & 8139.603 \\
\hline 790 & & & 1 & & & & & & & & & & & $242+65$ & 25 & 4132.292 & 8139.601 \\
\hline 791 & 1 & & & & & & & & & & & & & $242+65$ & 25 & 4132.292 & 8139.603 \\
\hline 792 & & & & & & & & 1 & & & & & & $242+65$ & 10 & 4132.290 & 8139.603 \\
\hline $792 A$ & & & & & & & & 1 & & & & & & $242+60$ & 20 & 4132.290 & 8139.605 \\
\hline 793 & 1 & & & & & & & & & & & & & $242+55$ & 38 & 4132.291 & 8139.605 \\
\hline 794 & & & & & & & & 1 & & & & & & $242+55$ & 15 & 4132.290 & 8139.605 \\
\hline 795 & & & & & & & & 1 & & & & & & $242+40$ & 25 & 4132.291 & 8139.608 \\
\hline
\end{tabular}




\begin{tabular}{|c|c|c|c|c|c|c|c|c|c|c|c|c|c|c|c|c|c|}
\hline \multirow[t]{2}{*}{$\begin{array}{l}\text { Dolos } \\
\text { Number }\end{array}$} & \multicolumn{13}{|c|}{ Break Type } & \multicolumn{4}{|c|}{ Location } \\
\hline & $\begin{array}{l}\text { Straight } \\
\text { Shank }\end{array}$ & $\begin{array}{l}\text { Straight } \\
\text { Mid } \\
\text { Shank }\end{array}$ & $\begin{array}{l}\text { Angled } \\
\text { Shank }\end{array}$ & $\begin{array}{l}\text { Angled } \\
\text { Mid } \\
\text { Shank }\end{array}$ & $\begin{array}{l}\text { Cracked } \\
\text { Shank }\end{array}$ & $\begin{array}{l}\text { Straight } \\
\text { Fluke }\end{array}$ & $\begin{array}{l}\text { Straight } \\
\text { Fluke } \\
\text { Tip }\end{array}$ & $\begin{array}{l}\text { Angled } \\
\text { Fluke }\end{array}$ & $\begin{array}{l}\text { Angled } \\
\text { Fluke } \\
\text { Tip }\end{array}$ & $\begin{array}{l}\text { Cracked } \\
\text { Fluke }\end{array}$ & $\begin{array}{l}\text { Damaged } \\
\text { Fluke }\end{array}$ & $\begin{array}{c}\text { Damaged/ } \\
\text { Broken } \\
\text { Fluke Tip }\end{array}$ & Pieces & $\begin{array}{l}\text { Station } \\
\text { Number }\end{array}$ & $\begin{array}{l}\text { Distance } \\
\text { from } \\
\text { Baseline }\end{array}$ & $\begin{array}{c}\text { GPS North } \\
\text { (Decimal } \\
\text { degrees) }\end{array}$ & $\begin{array}{l}\text { GPS 38st } \\
\text { (Decimal } \\
\text { degrees) }\end{array}$ \\
\hline 796 & 1 & & & & & & & & & & & & & $242+35$ & 25 & 4132.289 & 8139.610 \\
\hline 797 & & & & & & & & 2 & & & & & & $242+35$ & 20 & 4132.289 & 8139.609 \\
\hline 798 & 1 & & & & & & & & & & & & & $242+35$ & 15 & 4132.288 & 8139.609 \\
\hline 799 & & & 1 & & & & & & & & & & & $242+35$ & 10 & 4132.287 & 8139.608 \\
\hline 800 & & & & & & 1 & & & & & & & & $242+30$ & 5 & 4132.286 & 8139.607 \\
\hline $800 \mathrm{~A}$ & & & & & & 1 & & & & & & & & $242+35$ & 5 & 4132.287 & 8139.607 \\
\hline 801 & & & 1 & & & & & & & & & & & $242+25$ & 15 & 4132.286 & 8139.610 \\
\hline 802 & 1 & & & & & & & & & & & & & $242+25$ & 20 & 4132.287 & 8139.610 \\
\hline 803 & & & & & & & & 1 & & & & & & $242+25$ & 38 & 4132.287 & 8139.610 \\
\hline 804 & & & 1 & & & & & & & & & & & $242+20$ & 20 & 4132.286 & 8139.610 \\
\hline 805 & 1 & & & & & & & & & & & & & $242+15$ & 10 & 4132.286 & 8139.610 \\
\hline 806 & 1 & & & & & & & & & & & & & $242+20$ & 38 & 4132.285 & 8139.611 \\
\hline 807 & & & 1 & & & & & & & & & & & $242+15$ & 20 & 4132.286 & 8139.612 \\
\hline 808 & 1 & & & & & & & 1 & & & & & 1 & $242+15$ & 25 & 4132.286 & 8139.612 \\
\hline 809 & & & 1 & & & & & & & & & & & $242+00$ & 20 & 4132.286 & 8139.612 \\
\hline 810 & & & 1 & & & & & & & & & & & $242+00$ & 15 & 4132.286 & 8139.611 \\
\hline 811 & & & & & & & & & & & & & 1 & $242+00$ & 15 & 4132.285 & 8139.613 \\
\hline 812 & & & & & & & & 1 & & & & & & $241+90$ & 15 & 4132.285 & 8139.615 \\
\hline $812 \mathrm{~A}$ & & & & & & & & 1 & & & & & & $241+90$ & 38 & 4132.284 & 8139.617 \\
\hline 813 & 1 & & & & & & & & & & & & & $241+85$ & 20 & 4132.285 & 8139.614 \\
\hline 814 & 1 & & & & & & & & & & & & & $241+80$ & 20 & 4132.284 & 8139.617 \\
\hline 815 & & & 1 & & & & & & & & & & & $241+80$ & 20 & 4132.284 & 8139.617 \\
\hline 816 & & & 1 & & & 1 & & & & & & & & $241+75$ & 20 & 4132.283 & 8139.618 \\
\hline
\end{tabular}




\begin{tabular}{|c|c|c|c|c|c|c|c|c|c|c|c|c|c|c|c|c|c|}
\hline \multirow[t]{2}{*}{$\begin{array}{c}\text { Dolos } \\
\text { Number }\end{array}$} & \multicolumn{13}{|c|}{ Break Type } & \multicolumn{4}{|c|}{ Location } \\
\hline & $\begin{array}{l}\text { Straight } \\
\text { Shank }\end{array}$ & $\begin{array}{l}\text { Straight } \\
\text { Mid } \\
\text { Shank }\end{array}$ & $\begin{array}{l}\text { Angled } \\
\text { Shank }\end{array}$ & $\begin{array}{l}\text { Angled } \\
\text { Mid } \\
\text { Shank }\end{array}$ & $\begin{array}{l}\text { Cracked } \\
\text { Shank }\end{array}$ & $\begin{array}{l}\text { Straight } \\
\text { Fluke }\end{array}$ & $\begin{array}{l}\text { Straight } \\
\text { Fluke } \\
\text { Tip }\end{array}$ & $\begin{array}{l}\text { Angled } \\
\text { Fluke }\end{array}$ & $\begin{array}{c}\text { Angled } \\
\text { Fluke } \\
\text { Tip }\end{array}$ & $\begin{array}{l}\text { Cracked } \\
\text { Fluke }\end{array}$ & $\begin{array}{l}\text { Damaged } \\
\text { Fluke }\end{array}$ & $\begin{array}{l}\text { Damaged/ } \\
\text { Broken } \\
\text { Fluke Tip }\end{array}$ & Pieces & $\begin{array}{l}\text { Station } \\
\text { Number }\end{array}$ & $\begin{array}{l}\text { Distance } \\
\text { from } \\
\text { Baseline }\end{array}$ & $\begin{array}{l}\text { GPS North } \\
\text { (Decimal } \\
\text { degrees) }\end{array}$ & $\begin{array}{l}\text { GPS 38st } \\
\text { (Decimal } \\
\text { degrees) }\end{array}$ \\
\hline 817 & & & 1 & & & & & & & & & & & $241+75$ & 15 & 4132.283 & 8139.617 \\
\hline 818 & 1 & & & & & & & & & & & & & $241+70$ & 0 & 4132.280 & 8139.618 \\
\hline 819 & & & & & & & & 1 & & & & & & $241+70$ & 5 & 4132.282 & 8139.618 \\
\hline 820 & & & & & & & & 1 & & & & & & $241+65$ & 0 & 4132.280 & 8139.619 \\
\hline 821 & 1 & & & & & & & & & & & & & $241+50$ & 25 & 4132.281 & 8139.624 \\
\hline $821 \mathrm{~A}$ & 1 & & & & & & & & & & & & & $241+45$ & 38 & 4132.281 & 8139.624 \\
\hline 822 & 1 & & & & & & & & & & & & & $241+40$ & 38 & 4132.281 & 8139.625 \\
\hline 823 & & & 1 & & & & & & & & & & & $241+30$ & 25 & 4132.279 & 8139.625 \\
\hline 824 & & & 1 & & & & & & & & & & & $241+25$ & 20 & 4132.279 & 8139.626 \\
\hline 825 & & & & & & & & 1 & & & & & & $241+20$ & 20 & 4132.279 & 8139.626 \\
\hline 826 & & & & 1 & & & & & & & & & & $241+20$ & 20 & 4132.278 & 8139.626 \\
\hline 827 & & & & & & & & 1 & & & & & & $241+20$ & 38 & 4132.279 & 8139.627 \\
\hline 828 & & & & & & & & & & & & & 1 & $241+15$ & 38 & 4132.279 & 8139.627 \\
\hline 829 & & & & & & & & 1 & & & & & & $241+40$ & 15 & 4132.276 & 8139.625 \\
\hline 830 & 1 & & & & & & & & & & & & & $241+15$ & 38 & 4132.277 & 8139.628 \\
\hline 831 & & & & & & & & 1 & & & & & & $241+15$ & 38 & 4132.277 & 8139.628 \\
\hline 832 & & & 1 & & & & & & & & & & & $241+05$ & 25 & 4132.276 & 8139.631 \\
\hline 833 & & & & & & & & & & & & & & $241+00$ & 20 & 4132.274 & 8139.631 \\
\hline 834 & & 1 & & & & & & & & & & & & $240+95$ & 20 & 4132.273 & 8139.633 \\
\hline 835 & & & 1 & & & & & & & & & & & $240+85$ & 20 & 4132.274 & 8139.634 \\
\hline 836 & 1 & & & & & & & & & & & & & $240+85$ & 15 & 4132.273 & 8139.634 \\
\hline 837 & 1 & & & & & & & & & & & & & $240+80$ & 25 & 4132.273 & 8139.635 \\
\hline 838 & & & 1 & & & & & & & & & & & $240+75$ & 20 & 4132.273 & 8139.636 \\
\hline
\end{tabular}




\begin{tabular}{|c|c|c|c|c|c|c|c|c|c|c|c|c|c|c|c|c|c|}
\hline \multirow[t]{2}{*}{$\begin{array}{c}\text { Dolos } \\
\text { Number }\end{array}$} & \multicolumn{13}{|c|}{ Break Type } & \multicolumn{4}{|c|}{ Location } \\
\hline & $\begin{array}{l}\text { Straight } \\
\text { Shank }\end{array}$ & $\begin{array}{l}\text { Straight } \\
\text { Mid } \\
\text { Shank }\end{array}$ & $\begin{array}{l}\text { Angled } \\
\text { Shank }\end{array}$ & $\begin{array}{l}\text { Angled } \\
\text { Mid } \\
\text { Shank }\end{array}$ & $\begin{array}{l}\text { Cracked } \\
\text { Shank }\end{array}$ & $\begin{array}{l}\text { Straight } \\
\text { Fluke }\end{array}$ & $\begin{array}{l}\text { Straight } \\
\text { Fluke } \\
\text { Tip }\end{array}$ & $\begin{array}{l}\text { Angled } \\
\text { Fluke }\end{array}$ & $\begin{array}{c}\text { Angled } \\
\text { Fluke } \\
\text { Tip }\end{array}$ & $\begin{array}{l}\text { Cracked } \\
\text { Fluke }\end{array}$ & $\begin{array}{l}\text { Damaged } \\
\text { Fluke }\end{array}$ & $\begin{array}{c}\text { Damaged/ } \\
\text { Broken } \\
\text { Fluke Tip }\end{array}$ & Pieces & $\begin{array}{l}\text { Station } \\
\text { Number }\end{array}$ & $\begin{array}{l}\text { Distance } \\
\text { from } \\
\text { Baseline }\end{array}$ & $\begin{array}{c}\text { GPS North } \\
\text { (Decimal } \\
\text { degrees) }\end{array}$ & $\begin{array}{l}\text { GPS 38st } \\
\text { (Decimal } \\
\text { degrees) }\end{array}$ \\
\hline 839 & & & 1 & & & & & & & & & & & $240+80$ & 15 & 4132.272 & 8139.635 \\
\hline 840 & 1 & & & & & & & & & & & & & $240+80$ & 15 & 4132.272 & 8139.635 \\
\hline 841 & & & 1 & & & & & & & & & & & $240+75$ & 38 & 4132.272 & 8139.637 \\
\hline 842 & & & 1 & & & & & & & & & & & $240+65$ & 20 & 4132.271 & 8139.638 \\
\hline 843 & & & & & & 1 & & & & & & & & $240+55$ & 15 & 4132.270 & 8139.639 \\
\hline 844 & 1 & & & & & & & & & & & & & $240+55$ & 38 & 4132.271 & 8139.639 \\
\hline 845 & & & & & & & & 2 & & & & & & $240+50$ & 15 & 4132.269 & 8139.640 \\
\hline 846 & & & & & & & & 1 & & & & & & $240+50$ & 15 & 4132.269 & 8139.641 \\
\hline $846 A$ & & & & & & 1 & & & & & & & & $240+55$ & 25 & 4132.270 & 8139.640 \\
\hline 847 & & & & & & & & 1 & & & & & & $240+50$ & 38 & 4132.267 & 8139.643 \\
\hline 848 & & & & & & & & 1 & & & & & & $240+40$ & 20 & 4132.268 & 8139.643 \\
\hline 849 & 1 & & & & & & & & & & & & & $240+35$ & 25 & 4132.268 & 8139.644 \\
\hline 850 & 1 & & & & & & & & & & & & & $240+35$ & 20 & 4132.268 & 8139.643 \\
\hline 851 & & & 1 & & & 1 & & & & & & & & $240+25$ & 15 & 4132.267 & 8139.644 \\
\hline 852 & & & & & & & & 1 & & & & & & $240+25$ & 10 & 4132.267 & 8139.646 \\
\hline 853 & 1 & & & & & & & & & & & & & $240+25$ & 38 & 4132.268 & 8139.646 \\
\hline $853 A$ & & & & & & & 1 & & & & & & & $240+15$ & 38 & 4132.266 & 8139.646 \\
\hline $853 \mathrm{~B}$ & 1 & & & & & & & & & & & & & $240+20$ & 25 & 4132.267 & 8139.646 \\
\hline 854 & & & 2 & & & & & & & & & & & $240+15$ & 25 & 4132.266 & 8139.648 \\
\hline 855 & & & & & & & & 1 & & & & & & $239+90$ & 25 & 4132.264 & 8139.651 \\
\hline 856 & & & & & & & & 1 & & & & & & $239+90$ & 25 & 4132.265 & 8139.651 \\
\hline 857 & & & & & & & & 1 & & & & & & $239+90$ & 5 & 4132.266 & 8139.643 \\
\hline 858 & & & & & & & & 1 & & & & & & $239+50$ & 5 & 4132.259 & 8139.656 \\
\hline
\end{tabular}




\begin{tabular}{|c|c|c|c|c|c|c|c|c|c|c|c|c|c|c|c|c|c|}
\hline \multirow[t]{2}{*}{$\begin{array}{c}\text { Dolos } \\
\text { Number }\end{array}$} & \multicolumn{13}{|c|}{ Break Type } & \multicolumn{4}{|c|}{ Location } \\
\hline & $\begin{array}{l}\text { Straight } \\
\text { Shank }\end{array}$ & $\begin{array}{l}\text { Straight } \\
\text { Mid } \\
\text { Shank }\end{array}$ & $\begin{array}{l}\text { Angled } \\
\text { Shank }\end{array}$ & $\begin{array}{c}\text { Angled } \\
\text { Mid } \\
\text { Shank }\end{array}$ & $\begin{array}{l}\text { Cracked } \\
\text { Shank }\end{array}$ & $\begin{array}{c}\text { Straight } \\
\text { Fluke }\end{array}$ & $\begin{array}{l}\text { Straight } \\
\text { Fluke } \\
\text { Tip }\end{array}$ & $\begin{array}{l}\text { Angled } \\
\text { Fluke }\end{array}$ & $\begin{array}{c}\text { Angled } \\
\text { Fluke } \\
\text { Tip }\end{array}$ & $\begin{array}{l}\text { Cracked } \\
\text { Fluke }\end{array}$ & $\begin{array}{l}\text { Damaged } \\
\text { Fluke }\end{array}$ & $\begin{array}{c}\text { Damaged/ } \\
\text { Broken } \\
\text { Fluke Tip }\end{array}$ & Pieces & $\begin{array}{l}\text { Station } \\
\text { Number }\end{array}$ & $\begin{array}{l}\text { Distance } \\
\text { from } \\
\text { Baseline }\end{array}$ & $\begin{array}{c}\text { GPS North } \\
\text { (Decimal } \\
\text { degrees) }\end{array}$ & $\begin{array}{l}\text { GPS 38st } \\
\text { (Decimal } \\
\text { degrees) }\end{array}$ \\
\hline 859 & & & & & & & & 1 & & & & & & $239+40$ & 38 & 4132.260 & 8139.658 \\
\hline 860 & 1 & & & & & & & & & & & & & $239+35$ & 15 & 4132.258 & 8139.659 \\
\hline 861 & & & 1 & & & & & & & & & & & $239+45$ & 38 & 4132.260 & 8139.659 \\
\hline 862 & & & & & & & & 1 & & & & & & $239+40$ & 25 & 4132.259 & 8139.661 \\
\hline 863 & & & & & & & & & & & & & 1 & $239+40$ & 38 & 4132.259 & 8139.662 \\
\hline 864 & & & & 1 & & & & & & & & & & $239+25$ & 20 & 4132.258 & 8139.662 \\
\hline $864 A$ & & & & 1 & & & & & & & & & & $239+30$ & 15 & 4132.259 & 8139.661 \\
\hline 865 & & & & & & 1 & & & & & & & & $239+15$ & 38 & 4132.256 & 8139.663 \\
\hline 866 & & & & & & 1 & & & & & & & & $239+05$ & 15 & 4132.255 & 8139.666 \\
\hline $866 A$ & & & & & & 1 & & & & & & & & $239+05$ & 20 & 4132.256 & 8139.665 \\
\hline 867 & & & & & & & & 1 & & & & & & $238+95$ & 20 & 4132.254 & 8139.667 \\
\hline 868 & & & & & & & & 1 & & & & & & $238+90$ & 25 & 4132.254 & 8139.667 \\
\hline 869 & & & 1 & & & & & & & & & & & $238+90$ & 30 & 4132.254 & 8139.669 \\
\hline 870 & 1 & & & & & & & & & & & & & $238+90$ & 30 & 4132.255 & 8139.669 \\
\hline 871 & & & 1 & & & & & & & & & & & $238+85$ & 25 & 4132.254 & 8139.671 \\
\hline 872 & & & & & & & & 1 & & & & & & $238+75$ & 38 & 4132.253 & 8139.670 \\
\hline 873 & 1 & & & & & & & & & & & & & $238+80$ & 15 & 4132.253 & 8139.671 \\
\hline 874 & & & & & & & & 1 & & & & & & $238+80$ & 38 & 4132.254 & 8139.671 \\
\hline 875 & & & 1 & & & & & & & & & & & $238+75$ & 25 & 4132.253 & 8139.671 \\
\hline 876 & & & 1 & & & & & & & & & & & $238+65$ & 25 & 4132.252 & 8139.674 \\
\hline 877 & & & 1 & & & 1 & & & & & & & & $238+60$ & 38 & 4132.252 & 8139.675 \\
\hline 878 & & & & & & & & 1 & & & & & & $238+55$ & 25 & 4132.252 & 8139.676 \\
\hline 879 & & & 1 & & & & & & & & & & & $238+55$ & 20 & 4132.251 & 8139.676 \\
\hline
\end{tabular}




\begin{tabular}{|c|c|c|c|c|c|c|c|c|c|c|c|c|c|c|c|c|c|}
\hline $\begin{array}{l}\text { Dolos } \\
\text { Number }\end{array}$ & \multicolumn{13}{|c|}{ Break Type } & \multicolumn{4}{|c|}{ Location } \\
\hline & $\begin{array}{l}\text { Straight } \\
\text { Shank }\end{array}$ & $\begin{array}{l}\text { Straight } \\
\text { Mid } \\
\text { Shank }\end{array}$ & $\begin{array}{l}\text { Angled } \\
\text { Shank }\end{array}$ & $\begin{array}{l}\text { Angled } \\
\text { Mid } \\
\text { Shank }\end{array}$ & $\begin{array}{l}\text { Cracked } \\
\text { Shank }\end{array}$ & $\begin{array}{l}\text { Straight } \\
\text { Fluke }\end{array}$ & $\begin{array}{l}\text { Straight } \\
\text { Fluke } \\
\text { Tip }\end{array}$ & $\begin{array}{l}\text { Angled } \\
\text { Fluke }\end{array}$ & $\begin{array}{l}\text { Angled } \\
\text { Fluke } \\
\text { Tip }\end{array}$ & $\begin{array}{l}\text { Cracked } \\
\text { Fluke }\end{array}$ & $\begin{array}{l}\text { Damaged } \\
\text { Fluke }\end{array}$ & $\begin{array}{l}\text { Damaged/ } \\
\text { Broken } \\
\text { Fluke Tip }\end{array}$ & Pieces & $\begin{array}{l}\text { Station } \\
\text { Number }\end{array}$ & $\begin{array}{l}\text { Distance } \\
\text { from } \\
\text { Baseline }\end{array}$ & $\begin{array}{l}\text { GPS North } \\
\text { (Decimal } \\
\text { degrees) }\end{array}$ & $\begin{array}{l}\text { GPS 38st } \\
\text { (Decimal } \\
\text { degrees) }\end{array}$ \\
\hline 880 & & & & & & & & 1 & & & & & & $238+40$ & 25 & 4132.251 & 8139.677 \\
\hline 881 & & & 1 & & & & & & & & & & & $238+40$ & 20 & 4132.251 & 8139.676 \\
\hline \multicolumn{18}{|l|}{882} \\
\hline 883 & 1 & & & & & & & & 1 & & & & & $238+50$ & 20 & 4132.250 & 8139.677 \\
\hline 884 & & & 1 & & & 1 & & & & & & & & $238+45$ & 20 & 4132.250 & 8139.678 \\
\hline 885 & & & & 1 & & & & & & & & & & $238+40$ & 38 & 4132.250 & 8139.678 \\
\hline 886 & & & & & & & & & & & & & & $238+35$ & 25 & 4132.250 & 8139.679 \\
\hline \multicolumn{18}{|l|}{887} \\
\hline 888 & & & 1 & & & 1 & & & & & & & & $238+30$ & 25 & 4132.249 & 8139.680 \\
\hline 889 & & & & & & & & 1 & & & & & & $238+35$ & -5 & 4132.246 & 8139.678 \\
\hline 890 & 1 & & & & & & & & & & & & & $238+15$ & 15 & 4132.247 & 8139.682 \\
\hline 891 & 1 & & & & & & & & & & & & & $238+25$ & 38 & 4132.248 & 8139.682 \\
\hline 892 & 1 & & & & & & & & & & & & & $238+00$ & 25 & 4132.246 & 8139.685 \\
\hline 893 & 1 & & & & & & & & & & & & & $237+90$ & 20 & 4132.245 & 8139.687 \\
\hline 894 & & & 1 & & & & & & & & & & & $237+85$ & 25 & 4132.245 & 8139.687 \\
\hline 895 & 1 & & & & & & & & & & & & & $237+90$ & 25 & 4132.244 & 8139.688 \\
\hline 896 & 1 & & & & & & & & & & & & & $237+80$ & 20 & 4132.244 & 8139.688 \\
\hline 897 & 1 & & & & & & & & & & & & & $237+80$ & 38 & 4132.244 & 8139.689 \\
\hline 898 & & & & 1 & & & & 1 & & & & & & $237+65$ & 38 & 4132.242 & 8139.691 \\
\hline 899 & 1 & & & & & 1 & & & & & & & & $237+70$ & 30 & 4132.243 & 8139.691 \\
\hline 900 & & & 1 & & & & & & & & & & & $225+80$ & 20 & 4132.241 & 8139.694 \\
\hline 901 & & & & & & & & 1 & & & & & & $225+80$ & 20 & 4132.239 & 8139.695 \\
\hline 902 & 1 & & & & & & & & & & & & & $237+45$ & 20 & 4132.239 & 8139.694 \\
\hline
\end{tabular}




\begin{tabular}{|c|c|c|c|c|c|c|c|c|c|c|c|c|c|c|c|c|c|}
\hline \multirow[t]{2}{*}{$\begin{array}{l}\text { Dolos } \\
\text { Number }\end{array}$} & \multicolumn{13}{|c|}{ Break Type } & \multicolumn{4}{|c|}{ Location } \\
\hline & $\begin{array}{l}\text { Straight } \\
\text { Shank }\end{array}$ & $\begin{array}{l}\text { Straight } \\
\text { Mid } \\
\text { Shank }\end{array}$ & $\begin{array}{l}\text { Angled } \\
\text { Shank }\end{array}$ & $\begin{array}{l}\text { Angled } \\
\text { Mid } \\
\text { Shank }\end{array}$ & $\begin{array}{l}\text { Cracked } \\
\text { Shank }\end{array}$ & $\begin{array}{l}\text { Straight } \\
\text { Fluke }\end{array}$ & $\begin{array}{c}\text { Straight } \\
\text { Fluke } \\
\text { Tip }\end{array}$ & $\begin{array}{l}\text { Angled } \\
\text { Fluke }\end{array}$ & $\begin{array}{l}\text { Angled } \\
\text { Fluke } \\
\text { Tip }\end{array}$ & $\begin{array}{l}\text { Cracked } \\
\text { Fluke }\end{array}$ & $\begin{array}{l}\text { Damaged } \\
\text { Fluke }\end{array}$ & $\begin{array}{c}\text { Damaged/ } \\
\text { Broken } \\
\text { Fluke Tip }\end{array}$ & Pieces & $\begin{array}{l}\text { Station } \\
\text { Number }\end{array}$ & $\begin{array}{l}\text { Distance } \\
\text { from } \\
\text { Baseline }\end{array}$ & $\begin{array}{c}\text { GPS North } \\
\text { (Decimal } \\
\text { degrees) }\end{array}$ & $\begin{array}{l}\text { GPS 38st } \\
\text { (Decimal } \\
\text { degrees) }\end{array}$ \\
\hline 903 & & & & & & & & 1 & & & & & & $237+45$ & 20 & 4132.240 & 8139.694 \\
\hline 904 & 1 & & & & & & & & & & & & & $237+40$ & 0 & 4132.237 & 8139.696 \\
\hline 905 & 1 & & & & & & & & & & & & & $237+30$ & -5 & 4132.236 & 8139.696 \\
\hline 906 & & & & & & 1 & & & & & & & & $237+30$ & 38 & 4132.239 & 8139.698 \\
\hline $906 \mathrm{~A}$ & & & 1 & & & & & & & & & & & $237+30$ & 20 & 4132.239 & 8139.698 \\
\hline 907 & & & & & & 1 & & 2 & & & & & & $237+30$ & 38 & 4132.238 & 8139.698 \\
\hline 908 & 1 & & & & & & & & & & & & & $237+20$ & 20 & 4132.236 & 8139.700 \\
\hline 909 & 1 & & & & & & & & & & & & & $237+20$ & 38 & 4132.237 & 8139.700 \\
\hline 910 & 1 & & & & & & & & & & & & & $237+20$ & 38 & 4132.238 & 8139.700 \\
\hline 911 & & & 1 & & & & & & & & & & & $237+15$ & 20 & 4132.236 & 8139.701 \\
\hline 912 & & & & & & & & 1 & & & & & & $237+15$ & 38 & 4132.236 & 8139.700 \\
\hline $912 \mathrm{~A}$ & & & & & & 1 & & & & & & & & $237+15$ & 25 & 4132.237 & 8139.702 \\
\hline 913 & 1 & & & & & & & 1 & & & & & & $237+00$ & 20 & 4132.234 & 8139.703 \\
\hline 914 & 1 & & & & & & & & & & & & & $237+00$ & 20 & 4132.235 & 8139.703 \\
\hline 915 & 1 & & & & & & & & & & & & & $236+95$ & 20 & 4132.235 & 8139.703 \\
\hline 916 & & & & & & & & 1 & & & & & & $236+90$ & 38 & 4132.235 & 8139.704 \\
\hline 917 & & & 1 & & & & & & & & & & & $236+90$ & 20 & 4132.235 & 8139.704 \\
\hline 918 & & & 1 & & & & & & & & & & & $236+85$ & 20 & 4132.235 & 8139.705 \\
\hline 919 & & & & & & 1 & & & & & & & & $236+80$ & 20 & 4132.234 & 8139.705 \\
\hline 920 & 1 & & & & & & & & & & & & & $236+80$ & 25 & 4132.233 & 8139.706 \\
\hline 921 & 1 & & & & & & & & & & & & & $236+80$ & 38 & 4132.234 & 8139.706 \\
\hline 922 & & & 1 & & & & & & & & & & & $236+75$ & 38 & 4132.233 & 8139.706 \\
\hline 923 & 1 & & & & & & & & & & & & & $236+75$ & 15 & 4132.233 & 8139.707 \\
\hline
\end{tabular}




\begin{tabular}{|c|c|c|c|c|c|c|c|c|c|c|c|c|c|c|c|c|c|}
\hline \multirow[t]{2}{*}{$\begin{array}{l}\text { Dolos } \\
\text { Number }\end{array}$} & \multicolumn{13}{|c|}{ Break Type } & \multicolumn{4}{|c|}{ Location } \\
\hline & $\begin{array}{l}\text { Straight } \\
\text { Shank }\end{array}$ & $\begin{array}{l}\text { Straight } \\
\text { Mid } \\
\text { Shank }\end{array}$ & $\begin{array}{l}\text { Angled } \\
\text { Shank }\end{array}$ & $\begin{array}{l}\text { Angled } \\
\text { Mid } \\
\text { Shank }\end{array}$ & $\begin{array}{l}\text { Cracked } \\
\text { Shank }\end{array}$ & $\begin{array}{l}\text { Straight } \\
\text { Fluke }\end{array}$ & $\begin{array}{l}\text { Straight } \\
\text { Fluke } \\
\text { Tip }\end{array}$ & $\begin{array}{l}\text { Angled } \\
\text { Fluke }\end{array}$ & $\begin{array}{l}\text { Angled } \\
\text { Fluke } \\
\text { Tip }\end{array}$ & $\begin{array}{l}\text { Cracked } \\
\text { Fluke }\end{array}$ & $\begin{array}{l}\text { Damaged } \\
\text { Fluke }\end{array}$ & $\begin{array}{l}\text { Damaged/ } \\
\text { Broken } \\
\text { Fluke Tip }\end{array}$ & Pieces & $\begin{array}{l}\text { Station } \\
\text { Number }\end{array}$ & $\begin{array}{l}\text { Distance } \\
\text { from } \\
\text { Baseline }\end{array}$ & $\begin{array}{l}\text { GPS North } \\
\text { (Decimal } \\
\text { degrees) }\end{array}$ & $\begin{array}{l}\text { GPS 38st } \\
\text { (Decimal } \\
\text { degrees) }\end{array}$ \\
\hline 924 & & & 1 & & & & & & & & & & & $236+75$ & 0 & 4132.231 & 8139.704 \\
\hline 925 & & & & & & & & 1 & & & & & & $236+60$ & 20 & 4132.231 & 8139.707 \\
\hline 926 & & & & & & & & 1 & & & & & & $236+65$ & 20 & 4132.232 & 8139.708 \\
\hline 927 & & & & & & & & & & & & & & $237+25$ & 15 & 4132.237 & 8139.697 \\
\hline $927 \mathrm{~A}$ & 1 & & & & & & & & & & & & & $236+55$ & 38 & 4132.231 & 8139.708 \\
\hline 928 & 1 & & & & & & & & & & & & & $236+55$ & 20 & 4132.232 & 8139.707 \\
\hline 929 & 1 & & & & & & & & & & & & & $236+50$ & 15 & 4132.230 & 8139.711 \\
\hline 930 & 1 & & & & & & & & & & & & & $236+50$ & 20 & 4132.230 & 8139.711 \\
\hline 931 & & 1 & & & & & & & & & & & & $236+50$ & 20 & 4132.231 & 8139.711 \\
\hline 932 & 1 & & & & & & & 1 & & & & & & $236+40$ & 20 & 4132.230 & 8139.712 \\
\hline 933 & 1 & & & & & & & & & & & & & $236+45$ & 25 & 4132.231 & 8139.710 \\
\hline 934 & & & 1 & & & 1 & & & & & & & & $236+55$ & 38 & 4132.231 & 8139.710 \\
\hline 935 & & & & & & 1 & & & & & & & & $236+45$ & 38 & 4132.230 & 8139.712 \\
\hline 936 & 1 & & & & & & & & & & & & & $236+40$ & 25 & 4132.230 & 8139.712 \\
\hline 937 & & & 1 & & & & & & & & & & & $236+35$ & 20 & 4132.229 & 8139.713 \\
\hline 938 & 1 & & & & & & & & & & & & & $236+30$ & 25 & 4132.229 & 8139.714 \\
\hline 939 & & & & & & 1 & & 2 & & & & & & $236+30$ & 38 & 4132.229 & 8139.714 \\
\hline 940 & & & & & & 1 & & & & & & & & $236+30$ & 38 & 4132.229 & 8139.713 \\
\hline 941 & 1 & & & & & & & & & & & & & $236+30$ & 20 & 4132.228 & 8139.714 \\
\hline 942 & & & & & & 1 & & & & & & & & $236+05$ & 38 & 4132.227 & 8139.718 \\
\hline 943 & & & & & 1 & 1 & & & & & & & & $236+05$ & 5 & 4132.225 & 8139.718 \\
\hline 944 & & & 1 & & & & & & & & & & & $236+00$ & 20 & 4132.226 & 8139.719 \\
\hline 945 & 1 & & & & & & & 1 & & & & & & $235+95$ & 15 & 4132.225 & 8139.720 \\
\hline
\end{tabular}




\begin{tabular}{|c|c|c|c|c|c|c|c|c|c|c|c|c|c|c|c|c|c|}
\hline \multirow[t]{2}{*}{$\begin{array}{c}\text { Dolos } \\
\text { Number }\end{array}$} & \multicolumn{13}{|c|}{ Break Type } & \multicolumn{4}{|c|}{ Location } \\
\hline & $\begin{array}{l}\text { Straight } \\
\text { Shank }\end{array}$ & $\begin{array}{l}\text { Straight } \\
\text { Mid } \\
\text { Shank }\end{array}$ & $\begin{array}{l}\text { Angled } \\
\text { Shank }\end{array}$ & $\begin{array}{l}\text { Angled } \\
\text { Mid } \\
\text { Shank }\end{array}$ & $\begin{array}{l}\text { Cracked } \\
\text { Shank }\end{array}$ & $\begin{array}{l}\text { Straight } \\
\text { Fluke }\end{array}$ & $\begin{array}{l}\text { Straight } \\
\text { Fluke } \\
\text { Tip }\end{array}$ & $\begin{array}{c}\text { Angled } \\
\text { Fluke }\end{array}$ & $\begin{array}{c}\text { Angled } \\
\text { Fluke } \\
\text { Tip }\end{array}$ & $\begin{array}{l}\text { Cracked } \\
\text { Fluke }\end{array}$ & $\begin{array}{c}\text { Damaged } \\
\text { Fluke }\end{array}$ & $\begin{array}{c}\text { Damaged/ } \\
\text { Broken } \\
\text { Fluke Tip }\end{array}$ & Pieces & $\begin{array}{l}\text { Station } \\
\text { Number }\end{array}$ & $\begin{array}{c}\text { Distance } \\
\text { from } \\
\text { Baseline }\end{array}$ & $\begin{array}{c}\text { GPS North } \\
\text { (Decimal } \\
\text { degrees) }\end{array}$ & $\begin{array}{l}\text { GPS 38st } \\
\text { (Decimal } \\
\text { degrees) }\end{array}$ \\
\hline 946 & & & 1 & & & & & & & & & & & $235+90$ & 0 & 4132.222 & 8139.720 \\
\hline 947 & & & 1 & & & & & & & & & & & $235+85$ & -5 & 4132.221 & 8139.720 \\
\hline 948 & 1 & & & & & & & & & & & & & $235+80$ & 20 & 4132.223 & 8139.724 \\
\hline 949 & & & & & & & & 1 & & & & & & $235+80$ & 25 & 4132.224 & 8139.725 \\
\hline 950 & & & & & & & & 1 & & & & & & $235+80$ & 20 & 4132.224 & 8139.724 \\
\hline 951 & & & & & & & & 1 & & & & & & $235+75$ & 20 & 4132.223 & 8139.725 \\
\hline 952 & & & 1 & & & & & & & & & & & $235+70$ & 20 & 4132.223 & 8139.726 \\
\hline 953 & & & & 1 & & & & & & & & & & $235+70$ & 38 & 4132.223 & 8139.726 \\
\hline $953 \mathrm{~A}$ & 1 & & & & & & & & & & & & & $235+65$ & 20 & 4132.222 & 8139.726 \\
\hline 954 & & & 1 & & & & & & & & & & & $235+65$ & 15 & 4132.221 & 8139.726 \\
\hline 955 & & & 1 & & & & & & & & & & & $235+60$ & 15 & 4132.221 & 8139.727 \\
\hline $955 \mathrm{~A}$ & & & & & & & & & & & & & 1 & $235+60$ & 38 & 4132.221 & 8139.726 \\
\hline 956 & & & 1 & & & & & & & & & & & $235+60$ & 0 & 4132.220 & 8139.726 \\
\hline 957 & & & & & & & & 1 & & & & & & $235+55$ & 5 & 4132.221 & 8139.726 \\
\hline 958 & & 1 & & & & & & & & & & & & $235+50$ & 20 & 4132.221 & 8139.728 \\
\hline 959 & & & & & & & & & & & & & & $235+50$ & 20 & 4132.221 & 8139.729 \\
\hline 960 & & & & & & 1 & & & & & & & & $235+50$ & 20 & 4132.220 & 8139.729 \\
\hline 961 & & & & & & & & 1 & & & & & & $235+40$ & 20 & 4132.220 & 8139.729 \\
\hline 962 & & & & & & & & 1 & & & & & & $235+40$ & 20 & 4132.220 & 8139.730 \\
\hline 963 & & & & & & & & 1 & & & & & & $235+15$ & 15 & 4132.216 & 8139.734 \\
\hline 964 & & & 1 & & & & & & & & & & & $235+10$ & 5 & 4132.215 & 8139.735 \\
\hline 965 & & & 1 & & & & & & & & & & & $235+10$ & 20 & 4132.217 & 8139.735 \\
\hline 966 & 1 & & & & & & & & & & & & & $235+10$ & 38 & 4132.218 & 8139.734 \\
\hline
\end{tabular}




\begin{tabular}{|c|c|c|c|c|c|c|c|c|c|c|c|c|c|c|c|c|c|}
\hline \multirow[t]{2}{*}{$\begin{array}{c}\text { Dolos } \\
\text { Number }\end{array}$} & \multicolumn{13}{|c|}{ Break Type } & \multicolumn{4}{|c|}{ Location } \\
\hline & $\begin{array}{l}\text { Straight } \\
\text { Shank }\end{array}$ & $\begin{array}{l}\text { Straight } \\
\text { Mid } \\
\text { Shank }\end{array}$ & $\begin{array}{l}\text { Angled } \\
\text { Shank }\end{array}$ & $\begin{array}{l}\text { Angled } \\
\text { Mid } \\
\text { Shank }\end{array}$ & $\begin{array}{l}\text { Cracked } \\
\text { Shank }\end{array}$ & $\begin{array}{c}\text { Straight } \\
\text { Fluke }\end{array}$ & $\begin{array}{c}\text { Straight } \\
\text { Fluke } \\
\text { Tip }\end{array}$ & $\begin{array}{l}\text { Angled } \\
\text { Fluke }\end{array}$ & $\begin{array}{c}\text { Angled } \\
\text { Fluke } \\
\text { Tip }\end{array}$ & $\begin{array}{l}\text { Cracked } \\
\text { Fluke }\end{array}$ & $\begin{array}{l}\text { Damaged } \\
\text { Fluke }\end{array}$ & $\begin{array}{l}\text { Damaged/ } \\
\text { Broken } \\
\text { Fluke Tip }\end{array}$ & Pieces & $\begin{array}{l}\text { Station } \\
\text { Number }\end{array}$ & $\begin{array}{l}\text { Distance } \\
\text { from } \\
\text { Baseline }\end{array}$ & $\begin{array}{c}\text { GPS North } \\
\text { (Decimal } \\
\text { degrees) }\end{array}$ & $\begin{array}{l}\text { GPS 38st } \\
\text { (Decimal } \\
\text { degrees) }\end{array}$ \\
\hline 967 & & & & & & 1 & & & & & & & & $235+05$ & 38 & 4132.218 & 8139.735 \\
\hline 968 & & & & & & & & 1 & & & & & & $235+00$ & 38 & 4132.217 & 8139.736 \\
\hline $968 \mathrm{~A}$ & & & & & & & & & & 1 & & & & $235+15$ & 20 & 4132.217 & 8139.733 \\
\hline 969 & 1 & & & & & & & 1 & & & & & & $235+05$ & 10 & 4132.215 & 8139.736 \\
\hline 970 & & & 1 & & & & & & & & & & & $234+85$ & 5 & 4132.213 & 8139.738 \\
\hline 971 & & & & & & & & & 1 & & & & & $234+90$ & 15 & 4132.214 & 8139.738 \\
\hline 972 & & & 1 & & & & & & & & & & & $234+80$ & 15 & 4132.213 & 8139.739 \\
\hline 973 & & & 1 & & & & & & & & & & & $234+80$ & 20 & 4132.212 & 8139.743 \\
\hline 974 & & & 1 & & & & & & & & & & & $234+75$ & 38 & 4132.214 & 8139.742 \\
\hline 975 & & & & & & & & 1 & & & & & & $234+80$ & 20 & 4132.213 & 8139.741 \\
\hline 976 & 1 & & & & & & & & & & & & & $234+60$ & 15 & 4132.212 & 8139.744 \\
\hline 977 & & & 1 & & & & & 1 & & & & & & $234+60$ & 20 & 4132.212 & 8139.743 \\
\hline 978 & & & & & & 1 & & & & & & & & $234+60$ & 10 & 4132.211 & 8139.743 \\
\hline 979 & & & 1 & & & & & & & & & & & $234+55$ & 0 & 4132.209 & 8139.745 \\
\hline 980 & & & & & 1 & & & & & & & & & $234+50$ & 15 & 4132.210 & 8139.745 \\
\hline $980 \mathrm{~A}$ & & & & & & & & & & 1 & & & & $234+45$ & 0 & 4132.208 & 8139.745 \\
\hline 981 & & & 1 & & & & & & & & & & & $234+25$ & 5 & 4132.207 & 8139.750 \\
\hline 982 & & 1 & & & & & & & & & & & & $234+25$ & 15 & 4132.207 & 8139.751 \\
\hline 983 & & & & & & & & 2 & & & & & & $234+30$ & 10 & 4132.207 & 8139.749 \\
\hline 984 & & & & & & & & & & & & & 1 & $234+25$ & 38 & 4132.208 & 8139.752 \\
\hline 985 & & & 1 & & & & & & & & & & & $234+25$ & 20 & 4132.210 & 8139.751 \\
\hline 986 & & & 1 & & & 1 & & & & & & & & $234+30$ & 38 & 4132.208 & 8139.750 \\
\hline $986 A$ & & & & & & & & 1 & & & & & & $234+20$ & 38 & 4132.209 & 8139.752 \\
\hline
\end{tabular}




\begin{tabular}{|c|c|c|c|c|c|c|c|c|c|c|c|c|c|c|c|c|c|}
\hline \multirow[t]{2}{*}{$\begin{array}{l}\text { Dolos } \\
\text { Number }\end{array}$} & \multicolumn{13}{|c|}{ Break Type } & \multicolumn{4}{|c|}{ Location } \\
\hline & $\begin{array}{l}\text { Straight } \\
\text { Shank }\end{array}$ & $\begin{array}{l}\text { Straight } \\
\text { Mid } \\
\text { Shank }\end{array}$ & $\begin{array}{l}\text { Angled } \\
\text { Shank }\end{array}$ & $\begin{array}{l}\text { Angled } \\
\text { Mid } \\
\text { Shank }\end{array}$ & $\begin{array}{l}\text { Cracked } \\
\text { Shank }\end{array}$ & $\begin{array}{l}\text { Straight } \\
\text { Fluke }\end{array}$ & $\begin{array}{l}\text { Straight } \\
\text { Fluke } \\
\text { Tip }\end{array}$ & $\begin{array}{l}\text { Angled } \\
\text { Fluke }\end{array}$ & $\begin{array}{l}\text { Angled } \\
\text { Fluke } \\
\text { Tip }\end{array}$ & $\begin{array}{l}\text { Cracked } \\
\text { Fluke }\end{array}$ & $\begin{array}{l}\text { Damaged } \\
\text { Fluke }\end{array}$ & $\begin{array}{c}\text { Damaged/ } \\
\text { Broken } \\
\text { Fluke Tip }\end{array}$ & Pieces & $\begin{array}{l}\text { Station } \\
\text { Number }\end{array}$ & $\begin{array}{l}\text { Distance } \\
\text { from } \\
\text { Baseline }\end{array}$ & $\begin{array}{c}\text { GPS North } \\
\text { (Decimal } \\
\text { degrees) }\end{array}$ & $\begin{array}{l}\text { GPS 38st } \\
\text { (Decimal } \\
\text { degrees) }\end{array}$ \\
\hline 987 & 1 & & & & & & & & & & & & & $234+15$ & 20 & 4132.207 & 8139.754 \\
\hline $987 \mathrm{~A}$ & & & & & & & & 1 & & & & & & $234+00$ & 38 & 4132.207 & 8139.755 \\
\hline 987B & 1 & & & & & & & & & & & & & $233+95$ & 38 & 4132.206 & 8139.755 \\
\hline $987 C$ & & & & & & & & 1 & & & & & & $234+00$ & 15 & 4132.204 & 8139.755 \\
\hline 988 & & & 1 & & & & & & & & & & & $233+90$ & 0 & 4132.202 & 8139.755 \\
\hline 989 & & & & & & & & 1 & & & & & & $233+90$ & 0 & 4132.201 & 8139.755 \\
\hline 990 & & & 1 & & & & & & & & & & & $233+80$ & 5 & 4132.202 & 8139.755 \\
\hline 991 & & & & & & 1 & & & & & & & & $233+80$ & 15 & 4132.204 & 8139.757 \\
\hline 992 & & & & & & 1 & & & & & & & & $233+75$ & 15 & 4132.203 & 8139.758 \\
\hline 993 & & & & & & 1 & & & & & & & & $233+75$ & 15 & 4132.203 & 8139.758 \\
\hline 994 & & & 1 & & & & & & & & & & & $233+60$ & 20 & 4132.202 & 8139.762 \\
\hline $994 \mathrm{~A}$ & & & & & 1 & & & & & 1 & & & & $233+65$ & 10 & 4132.201 & 8139.760 \\
\hline 995 & & & 1 & & & & & & & & & & & $233+55$ & 15 & 4132.201 & 8139.763 \\
\hline 996 & & & 1 & & & 1 & & & & & & & & $233+35$ & 10 & 4132.199 & 8139.765 \\
\hline 997 & 1 & & & & & 1 & & & & & & & & $233+35$ & 10 & 4132.197 & 8139.766 \\
\hline 998 & 1 & & & & & & & & & & & & & $233+30$ & 20 & 4132.199 & 8139.766 \\
\hline 999 & 1 & & & & & 1 & & & & & & & & $233+60$ & -5 & 4132.199 & 8139.767 \\
\hline $999 \mathrm{~A}$ & & & & & & & & & & 1 & & & & $233+30$ & 38 & & \\
\hline 1000 & & & & & & & & 1 & & & & & & $233+20$ & 5 & 4132.196 & 8139.769 \\
\hline 1001 & & & 1 & & & & & & & & & & & $233+25$ & 15 & 4132.198 & 8139.768 \\
\hline $1001 \mathrm{~A}$ & & & 1 & & & & & & & & & & & $233+25$ & 10 & 4132.197 & 8139.767 \\
\hline 1002 & & & & & & & & 1 & & & & & & $233+20$ & 25 & 4132.199 & 8139.769 \\
\hline 1003 & 1 & & & & & & & & & & & & & $233+10$ & 25 & 4132.196 & 8139.772 \\
\hline
\end{tabular}




\begin{tabular}{|c|c|c|c|c|c|c|c|c|c|c|c|c|c|c|c|c|c|}
\hline $\begin{array}{l}\text { Dolos } \\
\text { Number }\end{array}$ & \multicolumn{13}{|c|}{ Break Type } & \multicolumn{4}{|c|}{ Location } \\
\hline & $\begin{array}{l}\text { Straight } \\
\text { Shank }\end{array}$ & $\begin{array}{l}\text { Straight } \\
\text { Mid } \\
\text { Shank }\end{array}$ & $\begin{array}{l}\text { Angled } \\
\text { Shank }\end{array}$ & $\begin{array}{l}\text { Angled } \\
\text { Mid } \\
\text { Shank }\end{array}$ & $\begin{array}{l}\text { Cracked } \\
\text { Shank }\end{array}$ & $\begin{array}{l}\text { Straight } \\
\text { Fluke }\end{array}$ & $\begin{array}{l}\text { Straight } \\
\text { Fluke } \\
\text { Tip }\end{array}$ & $\begin{array}{l}\text { Angled } \\
\text { Fluke }\end{array}$ & $\begin{array}{l}\text { Angled } \\
\text { Fluke } \\
\text { Tip }\end{array}$ & $\begin{array}{l}\text { Cracked } \\
\text { Fluke }\end{array}$ & $\begin{array}{l}\text { Damaged } \\
\text { Fluke }\end{array}$ & $\begin{array}{l}\text { Damaged/ } \\
\text { Broken } \\
\text { Fluke Tip }\end{array}$ & Pieces & $\begin{array}{l}\text { Station } \\
\text { Number }\end{array}$ & $\begin{array}{l}\text { Distance } \\
\text { from } \\
\text { Baseline }\end{array}$ & $\begin{array}{l}\text { GPS North } \\
\text { (Decimal } \\
\text { degrees) }\end{array}$ & $\begin{array}{l}\text { GPS 38st } \\
\text { (Decimal } \\
\text { degrees) }\end{array}$ \\
\hline $1003 A$ & & & & & & & & 1 & & & & & & $233+10$ & 38 & 4132.197 & 8139.771 \\
\hline 1004 & & & & 1 & & & & & & & & & & $233+00$ & 15 & 4132.196 & 8139.773 \\
\hline 1005 & & & 1 & & & & & & & & & & & $233+00$ & 20 & 4132.196 & 8139.774 \\
\hline 1006 & 1 & & & & & & & & & & & & & $233+05$ & 15 & 4132.195 & 8139.772 \\
\hline 1007 & & & & 1 & & 1 & & & & & & & & $232+85$ & 10 & 4132.193 & 8139.775 \\
\hline 1008 & & & & & & 1 & & 1 & & & & & & $232+85$ & 10 & 4132.193 & 8139.774 \\
\hline 1009 & & & & 1 & & & & & & & & & & $232+85$ & 20 & 4132.194 & 8139.775 \\
\hline 1010 & 1 & & & & & & & & & & & & & $232+85$ & 15 & 4132.194 & 8139.775 \\
\hline \multicolumn{18}{|l|}{1011} \\
\hline 1012 & & & 1 & & & & & & & & & & & $232+80$ & 20 & 4132.194 & 8139.776 \\
\hline 1013 & 1 & & & & & & & & & & & & & $232+75$ & 20 & 4132.194 & 8139.776 \\
\hline 1014 & & & & & 1 & & & & & & & & & $232+75$ & 25 & 4132.194 & 8139.777 \\
\hline 1015 & & & & & & & & 1 & & & & & & $232+70$ & 5 & 4132.191 & 8139.777 \\
\hline 1016 & 1 & & & & & 1 & & & & & & & & $232+65$ & 5 & 4132.191 & 8139.777 \\
\hline 1017 & & & & & & & & 1 & & & & & & $232+65$ & 0 & 4132.190 & 8139.777 \\
\hline 1018 & & & 1 & & & 1 & & & & & & & & $232+65$ & 0 & 4132.190 & 8139.779 \\
\hline 1019 & & & & & & & & 2 & & & & & & $232+60$ & 0 & 4132.189 & 8139.779 \\
\hline 1020 & & & 1 & & & & & & & & & & & $232+55$ & 10 & 4132.190 & 8139.780 \\
\hline 1021 & & & & & & 1 & & & & & & & & $232+50$ & 5 & 4132.190 & 8139.779 \\
\hline 1022 & 1 & & & & & & & & & & & & & $232+75$ & 25 & 4132.193 & 8139.777 \\
\hline 1023 & & & & & & & & 2 & & & & & & $232+50$ & 38 & 4132.192 & 8139.783 \\
\hline 1024 & & & & & & & & 2 & & & & & & $232+50$ & 20 & 4132.191 & 8139.783 \\
\hline 1025 & & & & & & & & 1 & & & & & & $232+40$ & 15 & 4132.189 & 8139.783 \\
\hline
\end{tabular}




\begin{tabular}{|c|c|c|c|c|c|c|c|c|c|c|c|c|c|c|c|c|c|}
\hline \multirow[t]{2}{*}{$\begin{array}{l}\text { Dolos } \\
\text { Number }\end{array}$} & \multicolumn{13}{|c|}{ Break Type } & \multicolumn{4}{|c|}{ Location } \\
\hline & $\begin{array}{l}\text { Straight } \\
\text { Shank }\end{array}$ & $\begin{array}{l}\text { Straight } \\
\text { Mid } \\
\text { Shank }\end{array}$ & $\begin{array}{l}\text { Angled } \\
\text { Shank }\end{array}$ & $\begin{array}{l}\text { Angled } \\
\text { Mid } \\
\text { Shank }\end{array}$ & $\begin{array}{l}\text { Cracked } \\
\text { Shank }\end{array}$ & $\begin{array}{l}\text { Straight } \\
\text { Fluke }\end{array}$ & $\begin{array}{l}\text { Straight } \\
\text { Fluke } \\
\text { Tip }\end{array}$ & $\begin{array}{c}\text { Angled } \\
\text { Fluke }\end{array}$ & $\begin{array}{c}\text { Angled } \\
\text { Fluke } \\
\text { Tip }\end{array}$ & $\begin{array}{l}\text { Cracked } \\
\text { Fluke }\end{array}$ & $\begin{array}{c}\text { Damaged } \\
\text { Fluke }\end{array}$ & $\begin{array}{c}\text { Damaged/ } \\
\text { Broken } \\
\text { Fluke Tip }\end{array}$ & Pieces & $\begin{array}{l}\text { Station } \\
\text { Number }\end{array}$ & $\begin{array}{l}\text { Distance } \\
\text { from } \\
\text { Baseline }\end{array}$ & $\begin{array}{c}\text { GPS North } \\
\text { (Decimal } \\
\text { degrees) }\end{array}$ & $\begin{array}{l}\text { GPS 38st } \\
\text { (Decimal } \\
\text { degrees) }\end{array}$ \\
\hline 1026 & & & 1 & & & & & & & & & & & $232+50$ & 5 & 4132.190 & 8139.779 \\
\hline 1027 & & 1 & & & & & & & & & & & & $232+40$ & 5 & 4132.188 & 8139.783 \\
\hline 1028 & & 1 & & & & & & & & & & & & $232+40$ & 15 & 4132.188 & 8139.784 \\
\hline 1029 & & & 1 & & & & & & & & & & & $232+30$ & 38 & 4153.648 & 8166.31 \\
\hline 1030 & & & & 1 & & & & 1 & & & & & & $232+30$ & 20 & 4153.648 & 8166.310 \\
\hline $1030 \mathrm{~A}$ & & & 2 & & & & & & & & & & & $232+25$ & 25 & 4153.647 & 8166.312 \\
\hline 1031 & & & 1 & & & & & & & & & & & $232+30$ & 15 & 4153.647 & 8166.307 \\
\hline 1032 & & & 1 & & & & & & & & & & & $232+25$ & 20 & 4153.645 & 8166.312 \\
\hline 1033 & 1 & & & & & & & & & & & & & $232+25$ & 15 & 4153.645 & 8166.31 \\
\hline 1034 & 1 & & & & & & & & & & & & & $232+15$ & 15 & 4153.643 & 8166.313 \\
\hline 1035 & & & & & 1 & & & & & & & & & $232+15$ & 15 & 4153.643 & 8166.313 \\
\hline 1036 & & & & & & & & & & & & & 1 & $232+20$ & 38 & 4153.648 & 8166.312 \\
\hline 1037 & & & & & & & & & & & & & 1 & $232+15$ & 38 & 4153.645 & 8166.313 \\
\hline 1038 & & & & & & & & & & & & & 1 & $232+10$ & 38 & 4153.645 & 8166.313 \\
\hline 1039 & & & & & & & & & & & & & 1 & $232+05$ & 38 & & \\
\hline 1040 & & & & & & & & 1 & & & & & & $232+05$ & 20 & 4153.642 & 8166.318 \\
\hline 1041 & & & & & & & & & & & & 1 & & $231+95$ & 15 & 4153.64 & 8166.32 \\
\hline 1042 & & & 1 & & & & & & & & & & & $231+95$ & 10 & 4153.638 & 8166.318 \\
\hline 1043 & & & & & & & & 1 & & & & & & $231+80$ & 10 & 4153.637 & 8166.322 \\
\hline 1044 & 1 & & & & & & & & & & & & & $231+80$ & 20 & 4153.64 & 8166.325 \\
\hline 1045 & & & & & & & & 1 & & & & & & $231+60$ & 15 & 4153.633 & 8166.33 \\
\hline 1046 & & & & & & 1 & & & & & & & & $231+65$ & 20 & 4153.638 & 8166.328 \\
\hline 1047 & 1 & & & & & & & & & & & & & $231+60$ & 38 & 4153.637 & 8166.328 \\
\hline
\end{tabular}




\begin{tabular}{|c|c|c|c|c|c|c|c|c|c|c|c|c|c|c|c|c|c|}
\hline \multirow[t]{2}{*}{$\begin{array}{l}\text { Dolos } \\
\text { Number }\end{array}$} & \multicolumn{13}{|c|}{ Break Type } & \multicolumn{4}{|c|}{ Location } \\
\hline & $\begin{array}{c}\text { Straight } \\
\text { Shank }\end{array}$ & $\begin{array}{l}\text { Straight } \\
\text { Mid } \\
\text { Shank }\end{array}$ & $\begin{array}{l}\text { Angled } \\
\text { Shank }\end{array}$ & $\begin{array}{l}\text { Angled } \\
\text { Mid } \\
\text { Shank }\end{array}$ & $\begin{array}{l}\text { Cracked } \\
\text { Shank }\end{array}$ & $\begin{array}{l}\text { Straight } \\
\text { Fluke }\end{array}$ & $\begin{array}{c}\text { Straight } \\
\text { Fluke } \\
\text { Tip }\end{array}$ & $\begin{array}{l}\text { Angled } \\
\text { Fluke }\end{array}$ & $\begin{array}{l}\text { Angled } \\
\text { Fluke } \\
\text { Tip }\end{array}$ & $\begin{array}{l}\text { Cracked } \\
\text { Fluke }\end{array}$ & $\begin{array}{l}\text { Damaged } \\
\text { Fluke }\end{array}$ & $\begin{array}{c}\text { Damaged/ } \\
\text { Broken } \\
\text { Fluke Tip }\end{array}$ & Pieces & $\begin{array}{l}\text { Station } \\
\text { Number }\end{array}$ & $\begin{array}{c}\text { Distance } \\
\text { from } \\
\text { Baseline }\end{array}$ & $\begin{array}{c}\text { GPS North } \\
\text { (Decimal } \\
\text { degrees) }\end{array}$ & $\begin{array}{l}\text { GPS 38st } \\
\text { (Decimal } \\
\text { degrees) }\end{array}$ \\
\hline 1048 & 1 & & & & & & & & & & & & & $231+50$ & 15 & 4153.633 & 8166.33 \\
\hline 1049 & & & & & & & & 1 & & & & & & $234+45$ & 15 & 4153.632 & 8166.33 \\
\hline 1050 & & & & & & & & 1 & & & & & & $231+40$ & 15 & 4153.632 & 8166.335 \\
\hline 1051 & & & & & & & & & & & & 1 & & $231+40$ & 15 & 4153.632 & 8166.335 \\
\hline 1052 & 1 & & & & & & & & & & & & & $231+40$ & 38 & 4153.636 & 8166.331 \\
\hline 1053 & & & & & & & & & & 1 & & & & $231+35$ & 15 & 4153.63 & 8166.333 \\
\hline 1054 & & & & & & & & & & 1 & & & & $231+35$ & 20 & 4153.63 & 8166.337 \\
\hline 1055 & & & & & & & & 1 & & & & & & $231+35$ & 25 & 4153.63 & 8166.335 \\
\hline 1056 & & & & & & & & 1 & & & & & & $231+35$ & 15 & 4153.632 & 8166.335 \\
\hline 1057 & & & & & 1 & & & & & & & & & $231+30$ & 20 & 4153.63 & 8166.337 \\
\hline 1058 & 1 & & & & & & & & & & & & & $231+25$ & 10 & 41.53 .628 & 8166.337 \\
\hline 1059 & & & & & 1 & & & & & & & & & $231+30$ & 25 & 4153.317 & 8166.338 \\
\hline 1060 & & & & & & 1 & & & & & & & & $231+35$ & 38 & 4153.633 & 8166.338 \\
\hline 1061 & 1 & & & & & & & & & & & & & $231+30$ & 38 & 4153.632 & 8166.338 \\
\hline 1062 & & & & & & & & 1 & & & & & & $231+20$ & 38 & 4153.632 & 8166.338 \\
\hline 1063 & & 1 & & & & & & & & & & & & $231+25$ & 15 & 4153.63 & 8166.337 \\
\hline 1064 & & & & & & & & & & & & & & $231+25$ & 10 & 4153.63 & 8166.335 \\
\hline 1065 & 1 & & & & & & & & & & & & & $231+25$ & 10 & 4153.63 & 8166.335 \\
\hline 1066 & & & & & & & & 1 & & & & & & $231+30$ & 15 & 4153.63 & 8166.332 \\
\hline 1067 & & & & & 1 & 1 & & & & 1 & & & & $231+20$ & 10 & 4153.627 & 8166.337 \\
\hline 1068 & 1 & & & & & & & & & & & & & $231+10$ & 20 & 4153.627 & 8166.343 \\
\hline 1069 & & & 1 & & & & & & & & & & & $231+25$ & 15 & 4153.628 & 8166.338 \\
\hline 1070 & & & & & & & & 2 & & & & & & $231+20$ & 15 & 4153.628 & 8166.34 \\
\hline
\end{tabular}




\begin{tabular}{|c|c|c|c|c|c|c|c|c|c|c|c|c|c|c|c|c|c|}
\hline $\begin{array}{l}\text { Dolos } \\
\text { Number }\end{array}$ & \multicolumn{13}{|c|}{ Break Type } & \multicolumn{4}{|c|}{ Location } \\
\hline & $\begin{array}{l}\text { Straight } \\
\text { Shank }\end{array}$ & $\begin{array}{l}\text { Straight } \\
\text { Mid } \\
\text { Shank }\end{array}$ & $\begin{array}{l}\text { Angled } \\
\text { Shank }\end{array}$ & $\begin{array}{l}\text { Angled } \\
\text { Mid } \\
\text { Shank }\end{array}$ & $\begin{array}{l}\text { Cracked } \\
\text { Shank }\end{array}$ & $\begin{array}{l}\text { Straight } \\
\text { Fluke }\end{array}$ & $\begin{array}{l}\text { Straight } \\
\text { Fluke } \\
\text { Tip }\end{array}$ & $\begin{array}{l}\text { Angled } \\
\text { Fluke }\end{array}$ & $\begin{array}{l}\text { Angled } \\
\text { Fluke } \\
\text { Tip }\end{array}$ & $\begin{array}{l}\text { Cracked } \\
\text { Fluke }\end{array}$ & $\begin{array}{l}\text { Damaged } \\
\text { Fluke }\end{array}$ & $\begin{array}{l}\text { Damaged/ } \\
\text { Broken } \\
\text { Fluke Tip }\end{array}$ & Pieces & $\begin{array}{l}\text { Station } \\
\text { Number }\end{array}$ & $\begin{array}{l}\text { Distance } \\
\text { from } \\
\text { Baseline }\end{array}$ & $\begin{array}{l}\text { GPS North } \\
\text { (Decimal } \\
\text { degrees) }\end{array}$ & $\begin{array}{l}\text { GPS 38st } \\
\text { (Decimal } \\
\text { degrees) }\end{array}$ \\
\hline 1071 & 1 & & & & & & & & & & & & & $231+10$ & 10 & 4153.627 & 8166.343 \\
\hline 1072 & & & & & & & & 1 & & & & & & $231+05$ & 38 & 4153.63 & 8166.347 \\
\hline 1073 & 1 & & & & & 1 & & & & & & & & $231+10$ & 38 & & \\
\hline 1074 & 1 & & & & & & & & & & & & & $231+15$ & 38 & & \\
\hline 1075 & 1 & & & & & & & & & & & & & $231+10$ & 15 & 4153.628 & 8166.345 \\
\hline 1076 & & & & & & & & 2 & & & & & & $231+00$ & 10 & 4153.625 & 8166.347 \\
\hline 1077 & & & & & & 1 & & & & & & & & $230+90$ & 10 & 4153.623 & 8166.348 \\
\hline $1077 \mathrm{~A}$ & & & & & & & & 1 & & & & 1 & & $230+95$ & 10 & 4153.625 & 8166.348 \\
\hline 1078 & & & & & & & & 1 & & & & & & $230+90$ & 10 & 4153.623 & 8166.348 \\
\hline 1079 & & & & & & & & & & & & & & $230+90$ & 38 & 4153.627 & 8166.348 \\
\hline $1079 A$ & & & & & & & & 1 & & & & & & $230+90$ & 20 & 4153.625 & 8166.35 \\
\hline 1080 & & & & & & & & 1 & & & & & & $230+80$ & 15 & 4153.622 & 8166.352 \\
\hline 1081 & & & & & & & & 1 & & & & & & $230+80$ & 38 & 4153.623 & 8166.352 \\
\hline 1082 & & & & & & & & & & & & & & & & & \\
\hline 1083 & 1 & & & & & & & & & & & & & $230+75$ & 20 & 4153.622 & 8166.352 \\
\hline 1084 & 1 & & & & & & & & & & & & & $230+70$ & 0 & 4153.618 & 8166.352 \\
\hline 1085 & & & & & 1 & & & & & & & & & $230+65$ & 5 & 4153.618 & 8166.357 \\
\hline 1086 & 1 & & & & & & & & & & & & & $230+70$ & 20 & 4153.62 & 8166.355 \\
\hline 1087 & & & & & & & & 1 & & & & & & $230+60$ & 0 & 4153.617 & 8166.357 \\
\hline 1088 & & & 1 & & & & & & & & & & & $230+60$ & 5 & 4153.617 & 8166.357 \\
\hline 1089 & 1 & & & & & & & & & & & & & $230+55$ & 20 & 4153.621 & 8166.358 \\
\hline 1090 & & & & 1 & & & & & & & & & & $230+70$ & 20 & 4153.62 & 8166.357 \\
\hline 1091 & 1 & & & & & & & & & & & & & $230+55$ & 5 & 4153.617 & 8166.358 \\
\hline
\end{tabular}




\begin{tabular}{|c|c|c|c|c|c|c|c|c|c|c|c|c|c|c|c|c|c|}
\hline $\begin{array}{l}\text { Dolos } \\
\text { Number }\end{array}$ & & & & & & & Break Ty & & & & & & & & & cation & \\
\hline & $\begin{array}{l}\text { Straight } \\
\text { Shank }\end{array}$ & $\begin{array}{l}\text { Straight } \\
\text { Mid } \\
\text { Shank }\end{array}$ & $\begin{array}{l}\text { Angled } \\
\text { Shank }\end{array}$ & $\begin{array}{l}\text { Angled } \\
\text { Mid } \\
\text { Shank }\end{array}$ & $\begin{array}{l}\text { Cracked } \\
\text { Shank }\end{array}$ & $\begin{array}{l}\text { Straight } \\
\text { Fluke }\end{array}$ & $\begin{array}{l}\text { Straight } \\
\text { Fluke } \\
\text { Tip }\end{array}$ & $\begin{array}{c}\text { Angled } \\
\text { Fluke }\end{array}$ & \begin{tabular}{|l} 
Angled \\
Fluke \\
Tip
\end{tabular} & $\begin{array}{c}\text { Cracked } \\
\text { Fluke }\end{array}$ & $\begin{array}{c}\text { Damaged } \\
\text { Fluke }\end{array}$ & $\begin{array}{l}\text { Damaged/ } \\
\text { Broken } \\
\text { Fluke Tip }\end{array}$ & Pieces & $\begin{array}{l}\text { Station } \\
\text { Number }\end{array}$ & $\begin{array}{l}\text { Distance } \\
\text { from } \\
\text { Baseline }\end{array}$ & $\begin{array}{l}\text { GPS North } \\
\text { (Decimal } \\
\text { degrees) }\end{array}$ & $\begin{array}{l}\text { GPS 38st } \\
\text { (Decimal } \\
\text { degrees) }\end{array}$ \\
\hline 1092 & & & & & & & & 1 & & & & & & $230+55$ & 15 & 4153.613 & 8166.363 \\
\hline 1093 & & & & & & 1 & & & & & & & & $230+45$ & 10 & 4153.617 & 8166.365 \\
\hline 1094 & & & 1 & & & & & & & & & & & $230+40$ & 15 & 4153.613 & 8166.362 \\
\hline 1095 & & & 1 & & & & & & & & & & & $230+40$ & 15 & 4153.613 & 8166.362 \\
\hline 1096 & & & 1 & & & & & & & & & & & $230+35$ & 15 & 4153.613 & 8166.362 \\
\hline 1097 & & & & & & & & & & 1 & & & & $230+05$ & 15 & 4153.61 & 8166.375 \\
\hline 1098 & 1 & & & & & & & & & & & & & $230+65$ & 0 & 4153.618 & 8166.357 \\
\hline $1098 \mathrm{~A}$ & & 1 & & & & & & & & & & & & $230+60$ & 15 & 4153.62 & 8166.357 \\
\hline 1099 & 1 & & & & & & & & & & & & & $230+65$ & 15 & 4153.618 & 81.664 \\
\hline
\end{tabular}




\section{Appendix B: Broken/Damaged Stone Armor Units (Type of Stone and Breaks) on Burns Harbor North Breakwater, August 2006 Walking Inspection}

\begin{tabular}{|c|c|c|c|c|c|}
\hline \multirow[b]{2}{*}{$\begin{array}{c}\text { Stone } \\
\text { No. }\end{array}$} & \multirow[b]{2}{*}{ Station } & \multicolumn{2}{|c|}{$\begin{array}{c}\text { Approximate Distance } \\
\text { from Baseline } \\
\text { m (ft) }\end{array}$} & \multirow[b]{2}{*}{ Type of Stone } & \multirow[b]{2}{*}{ Comments } \\
\hline & & $\begin{array}{l}\text { Lake } \\
\text { Side }\end{array}$ & $\begin{array}{l}\text { Harbor } \\
\text { Side }\end{array}$ & & \\
\hline 382 & Head & $1.2(4)$ & & Dolomite & Split into 2 pieces \\
\hline 380 & Head & & $1.5(5)$ & Indiana Bedford Limestone & Split into 3 pieces \\
\hline 381 & $0+00$ & $1.5(5)$ & & Dolomite & Split into 2 pieces \\
\hline 379 & $0+00$ & $0.6(2)$ & & Granite & Split into 3 pieces \\
\hline 378 & $0+25$ & & $3.05(10)$ & Indiana Bedford Limestone & Split into 3 pieces \\
\hline 377 & $0+25$ & & 3.7 (12) & Indiana Bedford Limestone & Split into 3 pieces \\
\hline 376 & $0+40$ & $8.2(27)$ & & Granite & Split into 3 pieces \\
\hline 375 & $0+35$ & \multicolumn{2}{|c|}{ Center Crest } & Indiana Bedford Limestone & Split into 2 pieces \\
\hline 374 & $0+35$ & \multicolumn{2}{|c|}{ Center Crest } & Dolomite & Split into 2 pieces \\
\hline 373 & $0+50$ & & $9.8(32)$ & Indiana Bedford Limestone & Cracked \\
\hline 372 & $0+50$ & $3.7(12)$ & & Indiana Bedford Limestone & Split - in underlayer \\
\hline 371 & $0+75$ & $9.8(32)$ & & Indiana Bedford Limestone & $\begin{array}{l}\text { Split into multiple pieces - } \\
\text { in underlayer }\end{array}$ \\
\hline 370 & $0+75$ & & $11.3(37)$ & Granite & Split into 2 pieces \\
\hline 367 & $1+00$ & $9.8(32)$ & & Granite & Split \\
\hline 366 & $1+00$ & $3.4(11)$ & & Granite & Split in half \\
\hline 365 & $1+20$ & & $7.6(25)$ & Dolomite & Broken corner \\
\hline 363 & $1+25$ & & $4.6(15)$ & Indiana Bedford Limestone & Horizontal crack \\
\hline 362 & $1+40$ & $5.2(17)$ & & Indiana Bedford Limestone & Split \\
\hline 361 & $1+75$ & $6.7(22)$ & & Indiana Bedford Limestone & Split - in underlayer \\
\hline 360 & $2+00$ & & $3.05(10)$ & Dolomite & Cracked \\
\hline 359 & $2+50$ & & $6.1(20)$ & Dolomite & Highly eroded/split \\
\hline 358 & $2+50$ & & $9.1(30)$ & Indiana Bedford Limestone & Split with Horizontal crack \\
\hline 356 & $3+00$ & \multicolumn{2}{|c|}{ Center Crest } & Dolomite & Split \\
\hline 355 & $3+00$ & & $4.6(15)$ & Dolomite & Eroded and falling apart \\
\hline 354 & $3+00$ & $7.0(23)$ & & Indiana Bedford Limestone & Split - in underlayer \\
\hline
\end{tabular}




\begin{tabular}{|c|c|c|c|c|c|}
\hline \multirow[b]{2}{*}{$\begin{array}{l}\text { Stone } \\
\text { No. }\end{array}$} & \multirow[b]{2}{*}{ Station } & \multicolumn{2}{|c|}{$\begin{array}{c}\text { Approximate Distance } \\
\text { from Baseline } \\
\text { m (ft) }\end{array}$} & \multirow[b]{2}{*}{ Type of Stone } & \multirow[b]{2}{*}{ Comments } \\
\hline & & $\begin{array}{l}\text { Lake } \\
\text { Side }\end{array}$ & $\begin{array}{l}\text { Harbor } \\
\text { Side }\end{array}$ & & \\
\hline 353 & $3+00$ & $4.0(13)$ & & Granite & Split into 2 pieces \\
\hline 352 & $3+00$ & 3.4 (11) & & Indiana Bedford Limestone & Split in corner \\
\hline 351 & $3+00$ & $3.4(11)$ & & Dolomite & Cracked \\
\hline 350 & $3+00$ & & $10.7(35)$ & Indiana Bedford Limestone & Split into 2 pieces \\
\hline 349 & $3+00$ & & $11.6(38)$ & Indiana Bedford Limestone & Cracked \\
\hline 348 & $3+30$ & $3.05(10)$ & & Indiana Bedford Limestone & Split \\
\hline 347 & $3+25$ & & $4.6(15)$ & Dolomite & Split into 3 pieces \\
\hline 346 & $3+25$ & & $4.6(15)$ & Dolomite & Cracked \\
\hline 345 & $3+50$ & & $4.6(15)$ & Dolomite & Pieces \\
\hline 344 & $3+50$ & $5.5(18)$ & & Indiana Bedford Limestone & Pieces \\
\hline 343 & $3+50$ & $4.0(13)$ & & Granite & Split into 4 pieces - void \\
\hline 342 & $3+50$ & \multicolumn{2}{|c|}{ Center Crest } & Indiana Bedford Limestone & Split into 2 pieces \\
\hline 341 & $3+50$ & & $1.2(4)$ & Dolomite & Split into 2 pieces \\
\hline 340 & $3+50$ & & $2.4(8)$ & Dolomite & Split into 3 pieces \\
\hline 339 & $3+75$ & & $9.1(30)$ & Dolomite & Split \\
\hline 338 & $3+75$ & & $7.6(25)$ & Dolomite & Cracked \\
\hline 337 & $3+75$ & \multicolumn{2}{|c|}{ Center Crest } & Dolomite & Split into 3 pieces \\
\hline 336 & $3+75$ & $8.5(28)$ & & Indiana Bedford Limestone & Split - in underlayer \\
\hline 335 & $4+00$ & $1.5(5)$ & & Indiana Bedford Limestone & Split \\
\hline 331 & $4+00$ & & $10.7(35)$ & Dolomite & Split into 2 pieces \\
\hline 330 & $4+00$ & & $1.8(6)$ & Dolomite & Cracked \\
\hline 329 & $4+00$ & $1.8(6)$ & & Indiana Bedford Limestone & Split into 2 pieces \\
\hline 328 & $4+00$ & $1.8(6)$ & & Granite & Split \\
\hline 327 & $4+50$ & $6.4(21)$ & & Indiana Bedford Limestone & Split - in underlayer \\
\hline 326 & $4+50$ & \multicolumn{2}{|c|}{ Center Crest } & Dolomite & Split into 2 pieces \\
\hline 325 & $4+50$ & $2.7(9)$ & & Indiana Bedford Limestone & Split - in underlayer \\
\hline 324 & $4+60$ & $1.5(5)$ & & Granite & Split into 3 pieces \\
\hline 323 & $4+75$ & $1.5(5)$ & & Indiana Bedford Limestone & Split into 4 pieces \\
\hline 322 & $4+75$ & $4.9(16)$ & & Granite & Split into 2 pieces \\
\hline 321 & $4+75$ & $3.05(10)$ & & Dolomite & Split into 2 pieces \\
\hline 320 & $4+75$ & & $5.5(18)$ & Quartzite & Split - in underlayer \\
\hline 319 & $4+80$ & & $4.9(16)$ & Dolomite & Split \\
\hline 318 & $4+95$ & $5.8(19)$ & & Indiana Bedford Limestone & $\begin{array}{l}\text { Split into } 3 \text { pieces - in } \\
\text { underlayer }\end{array}$ \\
\hline
\end{tabular}




\begin{tabular}{|c|c|c|c|c|c|}
\hline \multirow[b]{2}{*}{$\begin{array}{l}\text { Stone } \\
\text { No. }\end{array}$} & \multirow[b]{2}{*}{ Station } & \multicolumn{2}{|c|}{$\begin{array}{c}\text { Approximate Distance } \\
\text { from Baseline } \\
m \text { (ft) }\end{array}$} & \multirow[b]{2}{*}{ Type of Stone } & \multirow[b]{2}{*}{ Comments } \\
\hline & & $\begin{array}{l}\text { Lake } \\
\text { Side }\end{array}$ & $\begin{array}{l}\text { Harbor } \\
\text { Side }\end{array}$ & & \\
\hline 317 & $5+10$ & & $6.1(20)$ & Dolomite & Split \\
\hline 316 & $5+00$ & $4.6(15)$ & & Indiana Bedford Limestone & $\begin{array}{l}\text { Split into } 3 \text { pieces - in } \\
\text { underlayer }\end{array}$ \\
\hline 315 & $5+00$ & $7.6(25)$ & & Granite & Cracked \\
\hline 314 & $5+20$ & & $7.6(25)$ & Indiana Bedford Limestone & Broken corner \\
\hline 313 & $5+10$ & $3.05(10)$ & & Granite & Cracked \\
\hline 311 & $5+75$ & $3.05(10)$ & & Granite & Split \\
\hline 308 & $6+00$ & $8.2(27)$ & & Granite & Split and cracked \\
\hline 307 & $6+25$ & & $5.2(17)$ & Dolomite & Pieces \\
\hline 306 & $6+35$ & $3.05(10)$ & & Granite & Split into 2 pieces \\
\hline 305 & $6+50$ & $3.7(12)$ & & Granite & Split into 3 pieces \\
\hline 304 & $6+50$ & $4.3(14)$ & & Granite & Split into 2 pieces \\
\hline 303 & $6+50$ & $4.9(16)$ & & Granite & Corner split in 4 pieces \\
\hline 302 & $7+00$ & & $5.2(17)$ & Quartzite & Fractured into 3 pieces \\
\hline 301 & $7+00$ & $3.05(10)$ & & Dolomite & Split into multiple pieces \\
\hline 300 & $7+50$ & $3.05(10)$ & & Indiana Bedford Limestone & Split \\
\hline 299 & $7+75$ & $3.7(12)$ & & Indiana Bedford Limestone & Split \\
\hline 298 & $7+85$ & & $4.3(14)$ & Indiana Bedford Limestone & Split - in underlayer \\
\hline 297 & $7+85$ & $3.05(10)$ & & Dolomite & Split \\
\hline 296 & $8+20$ & $3.05(10)$ & & Indiana Bedford Limestone & Split \\
\hline 295 & $8+50$ & $3.05(10)$ & & Dolomite & Split into 2 pieces \\
\hline 294 & $8+50$ & $7.6(25)$ & & Dolomite & Pieces \\
\hline 293 & $8+50$ & $6.1(20)$ & & Dolomite & Pieces \\
\hline 292 & $8+50$ & & $3.05(10)$ & Indiana Bedford Limestone & Bottom cracked off \\
\hline 291 & $8+75$ & & $2.4(8)$ & Granite & 2 pieces broken off \\
\hline 290 & $9+00$ & $6.1(20)$ & & Indiana Bedford Limestone & $\begin{array}{l}\text { Split into } 3 \text { pieces - in } \\
\text { underlayer }\end{array}$ \\
\hline 288 & $9+60$ & $4.6(15)$ & & Indiana Bedford Limestone & Split \\
\hline 287 & $9+85$ & $4.3(14)$ & & Dolomite & Split \\
\hline 286 & $10+05$ & $3.05(10)$ & & Dolomite & Split \\
\hline 285 & $10+75$ & & $4.6(15)$ & Granite & Split into 2 pieces \\
\hline 284 & $11+20$ & & $10.7(35)$ & Indiana Bedford Limestone & Split - edge of water \\
\hline 283 & $10+90$ & & $1.5(5)$ & Dolomite & Fractured \\
\hline 282 & $11+00$ & $3.05(10)$ & & Dolomite & Cracked \\
\hline
\end{tabular}




\begin{tabular}{|c|c|c|c|c|c|}
\hline \multirow[b]{2}{*}{$\begin{array}{l}\text { Stone } \\
\text { No. }\end{array}$} & \multirow[b]{2}{*}{ Station } & \multicolumn{2}{|c|}{$\begin{array}{c}\text { Approximate Distance } \\
\text { from Baseline } \\
\mathrm{m}(\mathrm{ft})\end{array}$} & \multirow[b]{2}{*}{ Type of Stone } & \multirow[b]{2}{*}{ Comments } \\
\hline & & $\begin{array}{l}\text { Lake } \\
\text { Side }\end{array}$ & $\begin{array}{l}\text { Harbor } \\
\text { Side }\end{array}$ & & \\
\hline 281 & $12+00$ & $3.7(12)$ & & Indiana Bedford Limestone & Multiple fractures \\
\hline 280 & $12+15$ & $10.7(35)$ & & Indiana Bedford Limestone & Split - edge of water \\
\hline 279 & $12+25$ & & $3.7(12)$ & Indiana Bedford Limestone & Cracked \\
\hline 278 & $12+50$ & $6.1(20)$ & & Indiana Bedford Limestone & $\begin{array}{l}\text { Split into } 3 \text { pieces - in } \\
\text { underlayer }\end{array}$ \\
\hline 277 & $12+65$ & $3.05(10)$ & & Indiana Bedford Limestone & Split \\
\hline 276 & $13+10$ & $4.6(15)$ & & Indiana Bedford Limestone & Split into 5 pieces \\
\hline 275 & $12+85$ & $1.8(6)$ & & Dolomite & Split and cracked \\
\hline 274 & $13+25$ & $7.6(25)$ & & Indiana Bedford Limestone & Split - in underlayer \\
\hline 273 & $13+60$ & $3.05(10)$ & & Indiana Bedford Limestone & Split \\
\hline 272 & $13+80$ & $1.8(6)$ & & Indiana Bedford Limestone & Split \\
\hline 271 & $14+00$ & & $3.05(10)$ & Granite & Split corner \\
\hline 270 & $14+25$ & $7.6(25)$ & & Indiana Bedford Limestone & Split \\
\hline 269 & $14+50$ & $7.6(25)$ & & Indiana Bedford Limestone & Split \\
\hline 268 & $14+35$ & & $3.7(12)$ & Indiana Bedford Limestone & Split - in underlayer \\
\hline 267 & $15+50$ & & $3.7(12)$ & Indiana Bedford Limestone & Split - in underlayer \\
\hline 266 & $15+50$ & & $4.3(14)$ & Granite & Cracked \\
\hline 265 & $15+60$ & & $3.05(10)$ & Granite & Broken corner \\
\hline 264 & $16+00$ & \multicolumn{2}{|c|}{ Center Crest } & Dolomite & Split and cracked \\
\hline 263 & $16+10$ & \multicolumn{2}{|c|}{ Center Crest } & Dolomite & Split into 2 pieces \\
\hline 262 & $16+10$ & $3.7(12)$ & & Indiana Bedford Limestone & Split \\
\hline 261 & $16+10$ & $3.7(12)$ & & Indiana Bedford Limestone & Split \\
\hline 260 & $16+40$ & & $3.7(12)$ & Indiana Bedford Limestone & Cracked \\
\hline 259 & $16+50$ & $4.9(16)$ & & Indiana Bedford Limestone & Split - in underlayer \\
\hline 258 & $16+40$ & & $3.05(10)$ & Indiana Bedford Limestone & \\
\hline 257 & $16+50$ & & $5.8(19)$ & Indiana Bedford Limestone & Split \\
\hline 256 & $16+60$ & $4.3(14)$ & & Dolomite & Split \\
\hline 255 & $16+60$ & $6.7(22)$ & & Indiana Bedford Limestone & Split \\
\hline 254 & $16+75$ & \multicolumn{2}{|c|}{ Center Crest } & Indiana Bedford Limestone & Split \\
\hline 253 & $16+90$ & $9.8(32)$ & & Indiana Bedford Limestone & Split \\
\hline 252 & $17+50$ & & $8.8(29)$ & Indiana Bedford Limestone & Split \\
\hline 251 & $17+50$ & & $3.05(10)$ & Dolomite & Sliver \\
\hline 250 & $17+90$ & & $3.05(10)$ & Indiana Bedford Limestone & Split \\
\hline 249 & $17+90$ & & $3.05(10)$ & Indiana Bedford Limestone & Crushed from impact \\
\hline
\end{tabular}




\begin{tabular}{|c|c|c|c|c|c|}
\hline \multirow[b]{2}{*}{$\begin{array}{l}\text { Stone } \\
\text { No. }\end{array}$} & \multirow[b]{2}{*}{ Station } & \multicolumn{2}{|c|}{$\begin{array}{c}\text { Approximate Distance } \\
\text { from Baseline } \\
m \text { (ft) }\end{array}$} & \multirow[b]{2}{*}{ Type of Stone } & \multirow[b]{2}{*}{ Comments } \\
\hline & & $\begin{array}{l}\text { Lake } \\
\text { Side }\end{array}$ & $\begin{array}{l}\text { Harbor } \\
\text { Side }\end{array}$ & & \\
\hline 248 & $17+90$ & & 3.05 (10) & Dolomite & $\begin{array}{l}\text { Split into } 3 \text { pieces - in } \\
\text { underlayer }\end{array}$ \\
\hline 246 & $18+75$ & & 3.05 (10) & Dolomite & Cracked \\
\hline 245 & $18+75$ & & $10.7(35)$ & Indiana Bedford Limestone & $4 \times 5 \times 3 \mathrm{ft}$ block broken off \\
\hline 244 & $18+75$ & $5.5(18)$ & & Indiana Bedford Limestone & Pieces \\
\hline 243 & $19+50$ & $3.05(10)$ & & Indiana Bedford Limestone & Split \\
\hline 242 & $19+50$ & $6.7(22)$ & & Indiana Bedford Limestone & Split - in underlayer \\
\hline 241 & $19+50$ & $3.7(12)$ & & Indiana Bedford Limestone & Split and cracked \\
\hline 240 & $20+25$ & \multicolumn{2}{|c|}{ Center Crest } & Indiana Bedford Limestone & Split down the middle \\
\hline 239 & $20+25$ & \multicolumn{2}{|c|}{ Center Crest } & Indiana Bedford Limestone & Pieces \\
\hline 238 & $19+80$ & $6.7(22)$ & & Indiana Bedford Limestone & Split \\
\hline 237 & $19+90$ & $3.05(10)$ & & Indiana Bedford Limestone & Split \\
\hline 236 & $20+00$ & & $4.3(14)$ & Indiana Bedford Limestone & Split down the grain \\
\hline 235 & $20+25$ & $3.7(12)$ & & Indiana Bedford Limestone & Split into 3 pieces \\
\hline 234 & $21+00$ & & $4.3(14)$ & Granite & Under \#232 \\
\hline 233 & $20+95$ & $3.7(12)$ & & Indiana Bedford Limestone & $\begin{array}{l}\text { Split into } 2 \text { pieces - in } \\
\text { underlayer }\end{array}$ \\
\hline 232 & $21+00$ & & $4.3(14)$ & Granite & $\begin{array}{l}\text { Split into } 3 \text { pieces- possibly } \\
\text { from impact }\end{array}$ \\
\hline 231 & $21+40$ & & $7.3(24)$ & Granite & 6 in. Split from impact \\
\hline 230 & $21+45$ & $5.2(17)$ & & Indiana Bedford Limestone & Split - in underlayer \\
\hline 229 & $21+40$ & & $7.3(24)$ & Granite & $\begin{array}{l}6 \text { in. Split and cracked } \\
\text { from impact }\end{array}$ \\
\hline 228 & $21+40$ & & 3.05 (10) & Indiana Bedford Limestone & $\begin{array}{l}\text { Corner split off from } \\
\text { impact }\end{array}$ \\
\hline 227 & $21+60$ & $3.7(12)$ & & Indiana Bedford Limestone & Split - in underlayer \\
\hline 226 & $21+60$ & $3.7(12)$ & & Indiana Bedford Limestone & Split - in underlayer \\
\hline 225 & $21+75$ & $3.05(10)$ & & Indiana Bedford Limestone & Split and cracked \\
\hline 224 & $21+75$ & \multicolumn{2}{|c|}{ Center Crest } & Granite & Cracked on 3 faces \\
\hline 223 & $22+10$ & $3.7(12)$ & & Indiana Bedford Limestone & Pieces \\
\hline 222 & $22+00$ & & 3.05 (10) & Dolomite & Corner broken off \\
\hline 221 & $22+00$ & & $2.4(8)$ & Indiana Bedford Limestone & Split in half \\
\hline 220 & $22+25$ & $4.3(14)$ & & Granite & Split into 3 pieces \\
\hline 219 & $22+40$ & $4.3(14)$ & & Indiana Bedford Limestone & Split into 4 pieces \\
\hline 218 & $22+50$ & & $7.3(24)$ & Dolomite & 2 cubic $\mathrm{ft}$ block broken off \\
\hline
\end{tabular}




\begin{tabular}{|c|c|c|c|c|c|}
\hline \multirow[b]{2}{*}{$\begin{array}{l}\text { Stone } \\
\text { No. }\end{array}$} & \multirow[b]{2}{*}{ Station } & \multicolumn{2}{|c|}{$\begin{array}{c}\text { Approximate Distance } \\
\text { from Baseline } \\
m \text { (ft) }\end{array}$} & \multirow[b]{2}{*}{ Type of Stone } & \multirow[b]{2}{*}{ Comments } \\
\hline & & $\begin{array}{l}\text { Lake } \\
\text { Side }\end{array}$ & $\begin{array}{l}\text { Harbor } \\
\text { Side }\end{array}$ & & \\
\hline 217 & $22+75$ & $6.7(22)$ & & Indiana Bedford Limestone & $\begin{array}{l}\text { Split into } 3 \text { pieces - in } \\
\text { underlayer }\end{array}$ \\
\hline 216 & $22+75$ & & $4.3(14)$ & Granite & Top $1 \mathrm{ft}$ split off \\
\hline 215 & $23+00$ & $3.05(10)$ & & Indiana Bedford Limestone & Split \\
\hline 214 & $23+10$ & & $6.7(22)$ & Dolomite & Split \\
\hline 213 & $23+25$ & $6.1(20)$ & & Dolomite & Split \\
\hline 212 & $23+30$ & $3.7(12)$ & & Indiana Bedford Limestone & Split \\
\hline 211 & $23+40$ & $3.05(10)$ & & Dolomite & Split \\
\hline 210 & $23+90$ & $3.7(12)$ & & Indiana Bedford Limestone & Split \\
\hline 209 & $24+30$ & $1.5(5)$ & & Dolomite & Split and pieces \\
\hline 207 & $24+30$ & $5.2(17)$ & & Indiana Bedford Limestone & Split - in underlayer \\
\hline 206 & $24+40$ & & $3.7(12)$ & Indiana Bedford Limestone & Split \\
\hline 205 & $24+65$ & & $6.1(20)$ & Dolomite & Pieces \\
\hline 204 & $24+65$ & $4.6(15)$ & & Granite & Split \\
\hline 203 & $24+65$ & $3.7(12)$ & & Granite & Split \\
\hline 201 & $25+00$ & $3.7(12)$ & & Indiana Bedford Limestone & Cracked \\
\hline 200 & $25+25$ & $6.7(22)$ & & Granite & Split \\
\hline 198 & $25+90$ & $3.4(11)$ & & Indiana Bedford Limestone & Split \\
\hline 197 & $26+00$ & & $10.4(34)$ & Dolomite & Split \\
\hline 196 & $26+30$ & $1.5(5)$ & & Dolomite & Split \\
\hline 195 & $27+00$ & & $7.3(24)$ & Dolomite & Split and cracked \\
\hline 194 & $26+90$ & & $4.6(15)$ & Dolomite & Split \\
\hline 193 & $27+15$ & 3.05 (10) & & Granite & Split \\
\hline 192 & $27+50$ & Cent & r Crest & Granite & Cracked \\
\hline 191 & $27+20$ & $6.7(22)$ & & Granite & Cracked \\
\hline 190 & $27+50$ & $6.7(22)$ & & Indiana Bedford Limestone & Cracked \\
\hline 189 & $28+35$ & & $10.4(34)$ & Indiana Bedford Limestone & Split \\
\hline 188 & $28+60$ & 3.05 (10) & & Indiana Bedford Limestone & Split \\
\hline 187 & $28+75$ & 3.05 (10) & & Indiana Bedford Limestone & Split - likely placement \\
\hline 186 & $29+25$ & & $4.3(14)$ & Granite & Pieces \\
\hline 185 & $29+25$ & & $5.8(19)$ & Granite & Split \\
\hline 184 & $29+75$ & $6.7(22)$ & & Indiana Bedford Limestone & Split \\
\hline 183 & $30+25$ & $4.6(15)$ & & Indiana Bedford Limestone & Split \\
\hline 182 & $30+20$ & $4.6(15)$ & & Dolomite & Split \\
\hline
\end{tabular}




\begin{tabular}{|c|c|c|c|c|c|}
\hline \multirow[b]{2}{*}{$\begin{array}{c}\text { Stone } \\
\text { No. }\end{array}$} & \multirow[b]{2}{*}{ Station } & \multicolumn{2}{|c|}{$\begin{array}{c}\text { Approximate Distance } \\
\text { from Baseline } \\
m \text { (ft) }\end{array}$} & \multirow[b]{2}{*}{ Type of Stone } & \multirow[b]{2}{*}{ Comments } \\
\hline & & $\begin{array}{l}\text { Lake } \\
\text { Side }\end{array}$ & $\begin{array}{l}\text { Harbor } \\
\text { Side }\end{array}$ & & \\
\hline 181 & $30+50$ & & $9.1(30)$ & Granite & Cracked \\
\hline 180 & $30+75$ & & $4.6(15)$ & Limestone -small & Multiple fractures \\
\hline 179 & $31+10$ & & $10.7(35)$ & Dolomite & Split with multiple cracks \\
\hline 178 & $31+10$ & $6.7(22)$ & & Granite & Pieces \\
\hline 177 & $31+35$ & & $2.4(8)$ & Limestone -small & Pieces \\
\hline 175 & $31+50$ & & $3.7(12)$ & Limestone -small & Multiple fractures \\
\hline 174 & $31+50$ & $1.5(5)$ & & Limestone -small & Split with cracks \\
\hline 173 & $31+85$ & \multicolumn{2}{|c|}{ Center Crest } & Limestone -small & Cracked \\
\hline 172 & $31+95$ & $3.05(10)$ & & Limestone -small & Pieces \\
\hline 171 & $31+95$ & $5.2(17)$ & & Indiana Bedford Limestone & Split \\
\hline 170 & $32+00$ & & $5.8(19)$ & Limestone -small & Split \\
\hline 169 & $32+10$ & $2.4(8)$ & & Limestone -small & Multiple cracks \\
\hline 168 & $32+10$ & $3.05(10)$ & & Limestone -small & Cracked \\
\hline 167 & $32+15$ & $6.7(22)$ & & Indiana Bedford Limestone & Split into 2 pieces \\
\hline 166 & $31+95$ & & $4.6(15)$ & Limestone -small & Pieces \\
\hline 164 & $32+00$ & & $3.7(12)$ & Limestone -small & Split \\
\hline 163 & $32+25$ & & $7.3(24)$ & Limestone -small & Split \\
\hline 162 & $32+30$ & & $10.4(34)$ & Limestone -small & Multiple fractures \\
\hline 161 & $32+30$ & & $7.3(24)$ & Limestone -small & Multiple fractures \\
\hline 160 & $32+40$ & & $3.05(10)$ & Dolomite & Pieces \\
\hline 159 & $32+40$ & & $5.5(18)$ & Dolomite & Cracked \\
\hline 158 & $32+50$ & & $4.3(14)$ & Dolomite & Split \\
\hline 157 & $32+60$ & & $7.3(24)$ & Dolomite & 3 broken corners \\
\hline 156 & $32+75$ & & $3.05(10)$ & Dolomite & Split \\
\hline 155 & $32+45$ & $3.7(12)$ & & Indiana Bedford Limestone & Split \\
\hline 154 & $33+00$ & $3.05(10)$ & & Dolomite & Split \\
\hline 153 & $32+90$ & $2.4(8)$ & & Indiana Bedford Limestone & Pieces \\
\hline 152 & $33+00$ & $3.05(10)$ & & Dolomite & Split \\
\hline 151 & $33+10$ & \multicolumn{2}{|c|}{ Center Crest } & Dolomite & Corner split in underlayer \\
\hline 150 & $33+00$ & \multicolumn{2}{|c|}{ Center Crest } & Dolomite & Multiple fractures \\
\hline 149 & $32+95$ & $4.6(15)$ & & Indiana Bedford Limestone & Split into 3 pieces \\
\hline 148 & $33+00$ & $4.6(15)$ & & Granite & Cracked \\
\hline 146 & $33+35$ & \multicolumn{2}{|c|}{ Center Crest } & Dolomite & Split \\
\hline
\end{tabular}




\begin{tabular}{|c|c|c|c|c|c|}
\hline \multirow[b]{2}{*}{$\begin{array}{c}\text { Stone } \\
\text { No. }\end{array}$} & \multirow[b]{2}{*}{ Station } & \multicolumn{2}{|c|}{$\begin{array}{c}\text { Approximate Distance } \\
\text { from Baseline } \\
m \text { (ft) }\end{array}$} & \multirow[b]{2}{*}{ Type of Stone } & \multirow[b]{2}{*}{ Comments } \\
\hline & & $\begin{array}{l}\text { Lake } \\
\text { Side }\end{array}$ & $\begin{array}{l}\text { Harbor } \\
\text { Side }\end{array}$ & & \\
\hline 145 & $33+55$ & $3.05(10)$ & & Dolomite & Split \\
\hline 143 & $33+75$ & & $5.8(19)$ & Indiana Bedford Limestone & Split \\
\hline 142 & $33+65$ & $2.4(8)$ & & Indiana Bedford Limestone & Multiple cracks \\
\hline 140 & $34+30$ & & $4.3(14)$ & Dolomite & Split \\
\hline 139 & $34+75$ & $4.3(14)$ & & Dolomite & Split into multiple pieces \\
\hline 138 & $34+90$ & & $1.2(4)$ & Dolomite & Split into multiple pieces \\
\hline 137 & $34+65$ & $3.7(12)$ & & Indiana Bedford Limestone & Cracked \\
\hline 136 & $35+00$ & & $4.3(14)$ & Dolomite & Split \\
\hline 135 & $35+40$ & & $3.05(10)$ & Dolomite & Multiple cracks \\
\hline 134 & $35+40$ & & $4.9(16)$ & Dolomite & Multiple pieces \\
\hline 133 & $35+40$ & $4.6(15)$ & & Granite & Cracked \\
\hline 132 & $35+45$ & $3.7(12)$ & & Dolomite & Cracks and split \\
\hline 131 & $35+85$ & & $3.7(12)$ & Dolomite & Multiple pieces \\
\hline 130 & $36+05$ & & $10.4(34)$ & Dolomite & Split \\
\hline 129 & $36+00$ & & $10.4(34)$ & Dolomite & Split \\
\hline 128 & $36+50$ & $3.05(10)$ & & Dolomite & Split \\
\hline 125 & $37+00$ & $3.7(12)$ & & Indiana Bedford Limestone & Split \\
\hline 124 & $37+25$ & $2.4(8)$ & & Indiana Bedford Limestone & Cracked \\
\hline 123 & $37+50$ & $3.05(10)$ & & Indiana Bedford Limestone & Split \\
\hline 122 & $38+00$ & & $1.8(6)$ & Dolomite & Split \\
\hline 121 & $38+00$ & & $3.7(12)$ & Indiana Bedford Limestone & Cracked \\
\hline 120 & $38+40$ & & $3.05(10)$ & Indiana Bedford Limestone & Split \\
\hline 119 & $38+50$ & $2.4(8)$ & & Indiana Bedford Limestone & Cracked - in underlayer \\
\hline 118 & $38+60$ & $3.05(10)$ & & Indiana Bedford Limestone & Pieces - Under granite \\
\hline 117 & $38+80$ & Cent & r Crest & Dolomite & Split \\
\hline 116 & $39+30$ & $1.8(6)$ & & Dolomite & Split \\
\hline 114 & $39+70$ & $1.8(6)$ & & Dolomite & Split \\
\hline 113 & $40+00$ & & $3.7(12)$ & Dolomite & Split and cracked \\
\hline 112 & $40+00$ & & $4.9(16)$ & Dolomite & Multiple cracks \\
\hline 111 & $40+50$ & & $9.8(32)$ & Dolomite & Split \\
\hline 109 & $41+20$ & & $10.4(34)$ & Indiana Bedford Limestone & Cracked \\
\hline 108 & $41+00$ & $3.05(10)$ & & Indiana Bedford Limestone & Corner split \\
\hline 106 & $41+25$ & $2.4(8)$ & & Indiana Bedford Limestone & Split into 5 pieces \\
\hline
\end{tabular}




\begin{tabular}{|c|c|c|c|c|c|}
\hline \multirow[b]{2}{*}{$\begin{array}{c}\text { Stone } \\
\text { No. }\end{array}$} & \multirow[b]{2}{*}{ Station } & \multicolumn{2}{|c|}{$\begin{array}{c}\text { Approximate Distance } \\
\text { from Baseline } \\
m \text { (ft) }\end{array}$} & \multirow[b]{2}{*}{ Type of Stone } & \multirow[b]{2}{*}{ Comments } \\
\hline & & $\begin{array}{l}\text { Lake } \\
\text { Side }\end{array}$ & $\begin{array}{l}\text { Harbor } \\
\text { Side }\end{array}$ & & \\
\hline 105 & $41+45$ & \multicolumn{2}{|c|}{ Center Crest } & Indiana Bedford Limestone & Multiple cracks \\
\hline 104 & $41+65$ & 3.05 (10) & & Dolomite & Pieces \\
\hline 103 & $42+75$ & $2.1(7)$ & & Indiana Bedford Limestone & Void in bottom of stone \\
\hline 102 & $42+00$ & & $4.3(14)$ & Indiana Bedford Limestone & Split \\
\hline 101 & $42+10$ & & $3.05(10)$ & Granite & Cracked \\
\hline 100 & $42+25$ & & 3.05 (10) & Indiana Bedford Limestone & Split into 3 pieces \\
\hline 99 & $42+45$ & & $3.05(10)$ & Indiana Bedford Limestone & Cracked \\
\hline 98 & $42+40$ & & 3.05 (10) & Indiana Bedford Limestone & Split \\
\hline 97 & $42+70$ & 3.05 (10) & & Indiana Bedford Limestone & Split - corner \\
\hline 96 & $42+55$ & $3.05(10)$ & & Indiana Bedford Limestone & Cracked \\
\hline 95 & $42+75$ & \multicolumn{2}{|c|}{ Center Crest } & Indiana Bedford Limestone & Split - in underlayer \\
\hline 93 & $43+00$ & $6.7(22)$ & & Indiana Bedford Limestone & Split \\
\hline 92 & $43+20$ & $6.7(22)$ & & Granite & Split \\
\hline 90 & $42+25$ & & $2.4(8)$ & Indiana Bedford Limestone & Split \\
\hline 89 & $43+40$ & & $3.05(10)$ & Granite & Split into 2 pieces \\
\hline 88 & $43+55$ & $3.05(10)$ & & Indiana Bedford Limestone & Pieces- directly under 87 \\
\hline 87 & $43+55$ & $2.4(8)$ & & Indiana Bedford Limestone & Cracked \\
\hline 86 & $44+10$ & $3.7(12)$ & & Indiana Bedford Limestone & Split - multiple \\
\hline 85 & $44+15$ & $2.4(8)$ & & Indiana Bedford Limestone & Split \\
\hline 84 & $44+25$ & $4.3(14)$ & & Indiana Bedford Limestone & Cracked \\
\hline 83 & $44+45$ & $6.7(22)$ & & Indiana Bedford Limestone & Split and cracked \\
\hline 82 & $44+65$ & $4.6(15)$ & & Indiana Bedford Limestone & Split - small piece \\
\hline 81 & $45+20$ & $6.7(22)$ & & Indiana Bedford Limestone & Split \\
\hline 80 & $45+35$ & $5.2(17)$ & & Indiana Bedford Limestone & Split \\
\hline 79 & $45+30$ & $5.2(17)$ & & Granite & Fractured along blast holes \\
\hline 78 & $46+00$ & $6.1(20)$ & & Indiana Bedford Limestone & Split \\
\hline 77 & $46+35$ & & $2.4(8)$ & Indiana Bedford Limestone & Corner split off \\
\hline 76 & $47+00$ & Cent & Crest & Indiana Bedford Limestone & Cracked \\
\hline
\end{tabular}




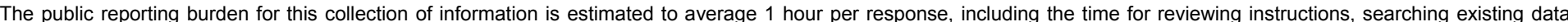

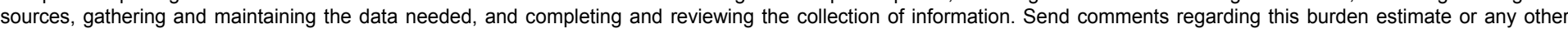

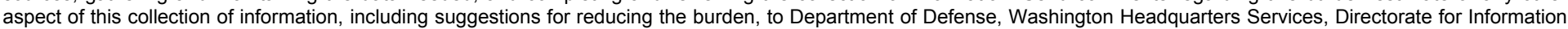

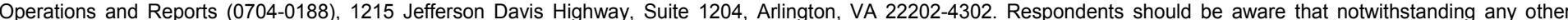
provision of law, no person shall be subject to any penalty for failing to comply with a collection of information if it does not display a currently valid OMB control number. PLEASE DO NOT RETURN YOUR FORM TO THE ABOVE ADDRESS.

\section{REPORT DATE}

May 2015

\section{TITLE AND SUBTITLE}

Periodic Inspections of Cleveland Harbor East Breakwater, Ohio; and Burns Harbor North

Breakwater, Indiana

\section{AUTHOR(S)}

Glenn B. Myrick, Jeffrey A. Melby, and Elizabeth C. Burg
3. DATES COVERED (From - To) 2006-2014

5a. CONTRACT NUMBER

5b. GRANT NUMBER

5c. PROGRAM ELEMENT NUMBER

5d. PROJECT NUMBER

5e. TASK NUMBER

5f. WORK UNIT NUMBER

8. PERFORMING ORGANIZATION REPORT NUMBER

ERDC/CHL TR-15-6

10. SPONSOR/MONITOR'S ACRONYM(S)

11. SPONSOR/MONITOR'S REPORT NUMBER(S)

441 G. Street, NW

Washington, DC 20314-1000

12. DISTRIBUTION/AVAILABILITY STATEMENT

Approved for public release; distribution is unlimited.

\section{SUPPLEMENTARY NOTES}

14. ABSTRACT (see reverse)

\section{SUBJECT TERMS}

Aerial photography

Breakwaters

16. SECURITY CLASSIFICATION OF:

\begin{tabular}{l|l|l} 
a. REPORT & b. ABSTRACT & c. THIS \\
UNCLASSIFIED & UNCLASSIFIED & PAGE
\end{tabular}

Concrete armor units

Dolosse

Lidar

17. LIMITATION OF ABSTRACT
18. NUMBER OF PAGES

120
Rubble-mound structures

Wave climate 19a. NAME OF RESPONSIBLE PERSON Glenn Myrick

19b. TELEPHONE NUMBER (Include area code) 601-634-4276 


\section{ABSTRACT (concluded)}

Monitoring Completed Navigation Projects (MCNP) Program evaluates the structural and functional performance of existing navigation structures. Under Periodic Inspections, aerial photography, ground-truth surveys, walking inspections, photogrammetry, and lidar elevation data are used to periodically assess the structural conditions of selected structures. A database of these structures is being compiled for asset management and other purposes.

Cleveland Harbor East Breakwater, OH, has sustained extensive damage since its construction in 1915. The Breakwater has had an extensive repair history, including a major rehabilitation in 1979-80 involving the placement of 2-ton dolosse on the lakeward slope and crest of the easterly 4,400 feet (ft). Some failed and were replaced with 4-ton dolosse. Other repairs took place in 1986, 1989, 1991, and 2001 on the nondolos sections.

Burns Harbor North Breakwater, IN, is a 4,640 ft rubble-mound structure constructed in 1969. The Breakwater has required extensive maintenance including the addition of 290 kilotons of stone through 1989. A submerged reef was constructed between 1995 and 1998 , $75 \mathrm{ft}$ lakeward of the Breakwater, to reduce wave energy reaching the structure.

Records indicate that 1,128 broken and/or cracked dolosse, and 282 damaged armor stones, were documented during the 2006 Periodic Inspections of Cleveland Harbor East Breakwater and Burns Harbor North Breakwater, respectively. This interim data report contains a precise record of dolos and stone armor damage existing in July 2006 on these structures. A comprehensive analysis and technical report correlating this damage with storm and water level conditions will be published at a later date as subsequent additional field data are obtained at these two Great Lakes breakwaters. 